\title{
GUILHERME FRANCISCO
}

\section{Eixo p53-hHR23B-XPC na modulação das vias de reparo de DNA em melanomas: Evidências para processos de carcinogênese, progressão e quimioresistência}

Tese apresentada à Faculdade de Medicina da Universidade de São Paulo para obtenção do título de Doutor em Ciências

Programa de Oncologia Orientador: Prof Dr. Roger Chammas

São Paulo 


\section{DEDICATÓRIA}

À minha incrível mãe Fátima Auxiliadora Francisco

Exemplo de mãe, amiga e mulher Á minha sobrinha Catarina Papadopoli, Amor Maior 


\section{AGRADECIMENTOS}

Em primeiro lugar ao Prof Dr. Roger Chammas, pela oportunidade de realizar esta tese e pelos inumeráveis ensinamentos.

À todos os alunos, ex-alunos e colaboradores do Grupo de Adesão Celular e Câncer pelos anos de amizade, convivência, e principalmente muito aprendizado. Em especial aos amigos que levarei para sempre.

À todos os alunos, funcionários e ex-colegas do LIM-24 e do CTO do ICESP, dos quais tive o prazer de conhecer e conviver ao longo destes anos.

Aos professores e colegas da UNESP Rio Claro pela formação em Biologia que me proporcionaram.

Às profas Dras Itamar Romano Garcia Ruiz, Doralice Maria Cella (In Memoriam) e Prof Dr. Ariovaldo Cruz-Neto pelo apoio aos primeiros passos.

Aos pesquisadores e alunos do Hospital AC Camargo, Instituto Ludwig e ICB dos quais tive a grande oportunidade de conviver e aprender.

Aos Profs Drs. Carlos Menck e Nadja Cristhina de Souza Pinto pelas conversas sobre reparo de DNA. 
Ao Dr. Denis Biard pelas conversas e gentil colaboração.

À todos os inúmeros amigos que a vida me proporcionou ao longo destes anos, aos quais a amizade, paciência, conselhos, parceria e momentos são de importância vital a todo ser humano, em especial à minha existência.

À minha melhor amiga e mãe da biologia Marlene Lipari Grimaldi, a qual tenho um sentimento de carinho e gratidão imensurável.

À todos os professores que tive oportunidade de conviver e que muito me ensinaram sobre esse dom.

Aos professores e colegas do Curso e Colégio Objetivo pela calorosa recepção e ensinamentos, em especial aos profs Marcelo, Moni, Spina, De Paula, Paiva, Surati, Lourenço, Sara e Barão. Ao prof Bellinello pela oportunidade e exemplo.

À Úrsula Urias pelo incentivo e companheirismo durante o período de tempo de convívio.

À toda minha amorosa família, em especial a minha irmã Luciana, meu cunhado Vinícius e a minha sobrinha Catarina, com certeza a melhor sensação do mundo em têla ao nosso lado. 
À FAPESP (Fundação de Amparo à Pesquisa do Estado de São Paulo) pelo apoio financeiro.

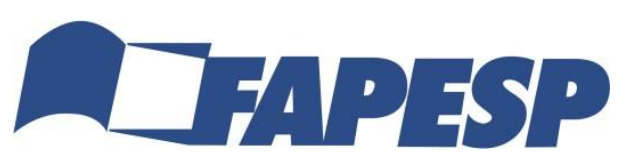

Ao CNPq (Conselho Nacional de Desenvolvimento Científico e Tecnológico) pelo apoio financeiro.

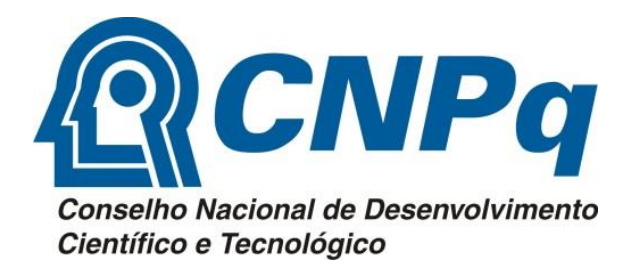


Nada em Biologia faz sentido, Exceto à luz da Evolução

(Theodozius Dobzhansky) 


\section{NORMALIZAÇÃO ADOTADA}

Esta tese está de acordo com as seguintes normas, em vigor no momento desta publicação:

Referências: adaptado de International Committee of Medical Journals Editors (Vancouver).

Universidade de São Paulo. Faculdade de Medicina. Divisão de Biblioteca e Documentação. Guia de apresentação de dissertações, teses e monografias. Elaborado por Anneliese Carneiro da Cunha, Maria Julia de A. L. Freddi, Maria F. Crestana, Marinalva de Souza Aragão, Suely Campos Cardoso, Valéria Vilhena. 3a ed. São Paulo: Divisão de Biblioteca e Documentação; 2011.

Abreviaturas dos títulos dos periódicos de acordo com List of Journals Indexed in Index Medicus. 


\section{SUMÁRIO}

\section{Lista de Abreviaturas}

\section{Lista de Figuras}

Lista de Tabelas

Resumo

Summary

1.INTRODUÇÃO 1

1.1 Desenvolvimento de Melanomas: Papel da Radiação UV ..................................1

1.2 Contrabalanceando os efeitos da Radiação UV: Genes e Sistema de Reparo de DNA. .5

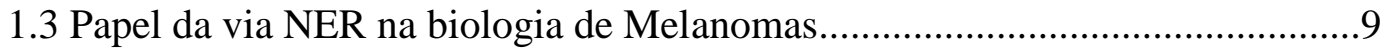

1.3.1 Via NER de Reparo de DNA e outros sistemas de Reparo na progressão

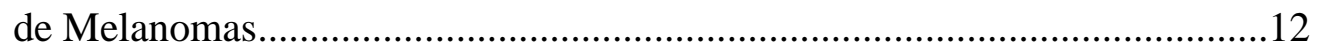

1.3.2 Via NER e resposta a quimioterápicos em Melanomas.........................14

1.4 Modulações da função de XPC e desenvolvimento de melanomas: Possíveis relações?

1.4.1 Modulação da atividade proteica de XPC: Funções da proteína

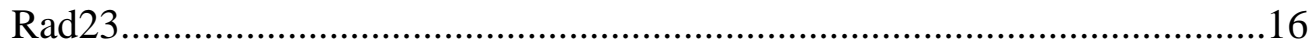

1.4.2 Modulação da expressão de XPC: papel de p53 ...................................9

1.4.3 Modulação de XPC: possível papel de polimorfismos genéticos?........21

2. OBJETIVOS .27

2.1 Objetivo Geral. .27

2.2 Objetivos específicos .27

2.2.1 Verificar o papel funcional de p53 em linhagens de melanoma expostas a UVB quanto a (o):

2.2.2 Verificar o possível papel de moduladores da função de XPC na biologia de melanomas, incluindo para isto:.

2.2.3 Verificar o papel funcional de p53 em linhagens de melanoma expostas a cisplatina quanto a (o): 


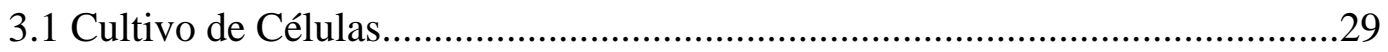

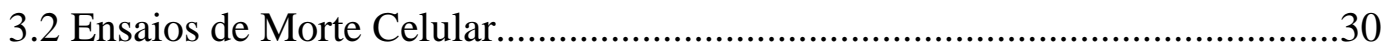

3.3 Morte Celular e Deprivação de Soro................................................................32

3.4 Ensaios de Sobrevivência por formação de colônias........................................32

3.5 Extração de Proteínas e Dosagem proteica......................................................33

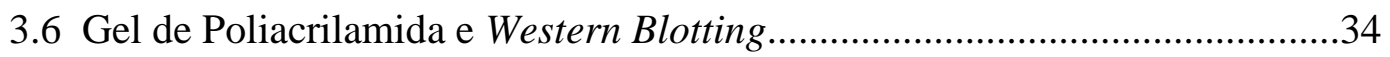

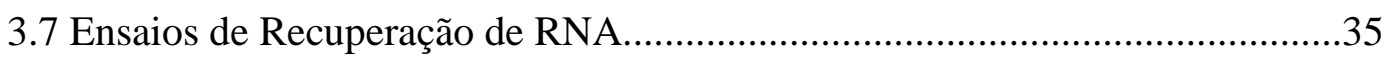

3.8 Ensaios de Reparo de DNA lesionados por UVB........................................36

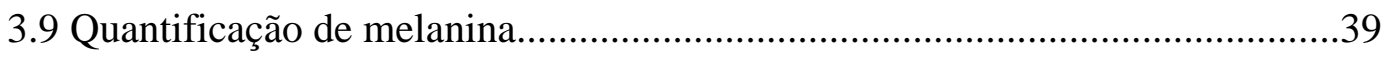

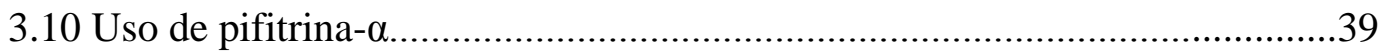

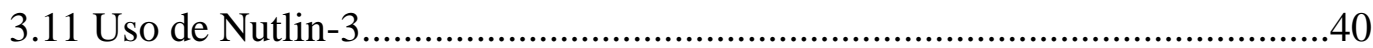

3.11 Análise de localização por imunofluorescência em microscopia confocal....41

3.12 Ensaio Caspase 3/7......

3.13 Ensaio de detecção de espécies reativas de oxigênio (ROS) por DHR e uso de Tempol e Catalase na sensibilidade à UVB...................................................43

3.14 Transdução da linhagem Skmel-28 com vetor p53 e GFP e experimento de proporção populacional em população mista.......................................................45

3.15 Tratamento com 5'AZA- 2' -deoxicitidina.................................................46

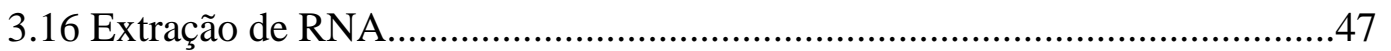

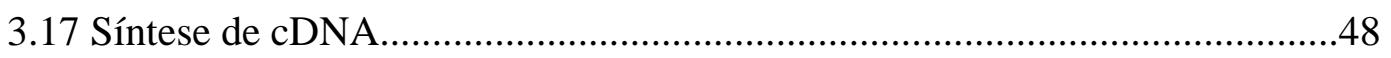

3.18 Análise da expressão gênica por quantitative RT-PCR (qRT-PCR)..............48

3.19 Silenciamento gênico por siRNA e experimentos de reparo de lesões UVB e sensibilidade a UVB e quimioterápicos................................................................

3.20 Sensibilidade a agentes quimioterápicos.................................................53

3.21 Análise imunohistoquimica para expressão de hHR23B em amostras de

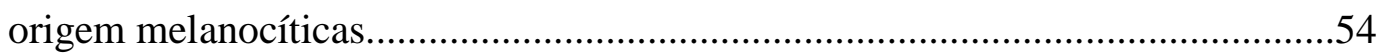

3.22 Extração de DNA e genotipagem quanto aos polimorfismos de XPC...........54

3.22 Análise de Expressão alelo-específica de XPC............................................58

3.23 Cálculos para análise de expressão alelo-específica de XPC K939Q.............59

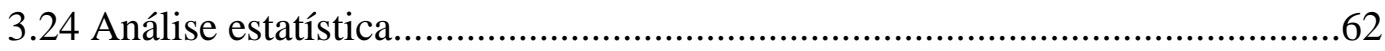


4.1 Papel de p53 na resposta a UVB.

4.1.1 Sensibilidade à exposição à UVB em linhagens de melanomas.

4.1.2 Expressão de proteínas da via NER, ensaio de recuperação de RNA e de

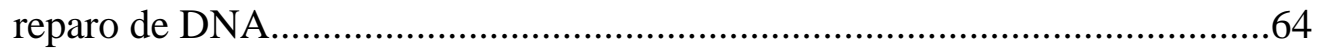

4.1.3 Papel de p53 na resposta à UVB em melanomas.................................68

4.1.4 Vias de Morte Celular em melanomas após UVB................................72

4.1.5 Produção de Espécies Reativas de Oxigênio (ROS) e sua relevância no processo de morte celular após UVB.........................................................76

4.2 Papel de hHR23B na biologia de melanomas.............................................81

4.2.1 Análise imunohistoquímica da expressão de hHR23B em amostras

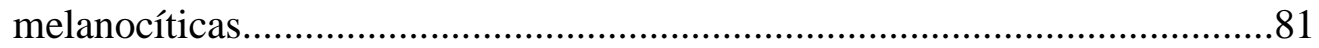

4.2.2 Expressão de hHR23A e hHR23B em linhagens de melanoma.............84

4.2.3 Efeito do uso de 5'Aza- 2'-deoxicitidina na expressão de hHR23B......88

4.2.4 Ensaios de morte celular após irradiação com UVB.............................89

4.2.5 Ensaios de Recuperação de RNA e Reparo de danos UVB...................90

4.2.6 Expressão e estabilidade de XPC nas linhagens de melanoma..............93

4.2.7 - Expressão e estabilidade de p53 nas linhagens de melanoma.............95

4.2.8 Imunolocalização de hHR23B e XPC na linhagem de melanoma Skmel37

4.2.9 Inibição da expressão de hHR23B e XPC por esiRNA........................98

4.2.10 Silenciamento de hHR23B e estabilidade e expressão de XPC...........99

4.2.11 Efeito do silenciamento de hHR23B e XPC na cinética de reparo de lesões UV

4.2.12 Sensibilidade a UVB em Skmel-37 após silenciamento de hHR23B e $\mathrm{XPC}$ 104

4.2.13 Papel de hHR23B e XPC na resposta a quimioterápicos 106

4.3 Função de polimorfismos de XPC no risco de desenvolvimento de melanoma e na expressão gênica..................................................................................... 111

4.3.1 Função dos polimorfismos de XPC no risco de melanomas. 111 
4.3.2 Genotipagem de linhagens de melanoma para os polimorfismos de $\mathrm{XPC}$

4.3.3 Padronização das metodologias usadas para quantificação alelo-

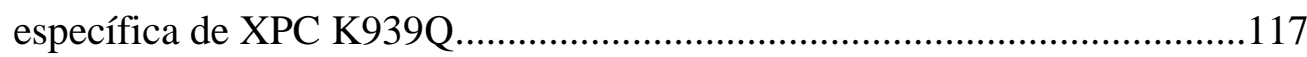

4.3.4 Expressão de XPC e expressão alelo-específica de XPC K939Q........124

4.4 Papel de p53 na resposta à Cisplatina.........................................................135

4.4.1 Sensibilidade das linhagens Skmel-28 e Skmel-37 à Cisplatina..........135

4.4.2 Exploração de vias relacionadas com resistência à cisplatina.............137

4.4.3 Inibição da atividade de p53 por pifithrin- $\alpha$.......................................139

4.4.4 Caracterização das vias de morte por exposição à cisplatina...............141

4.4.5 Modulação da atividade de p53 e sua relação com resposta à

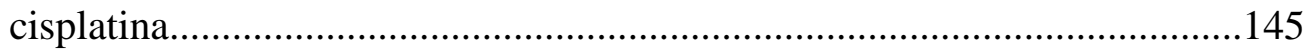

4.4.6 Papel de XPC na resistência à cisplatina...........................................150

4.4.7 Sensibilidade à cisplatina em componente heterogêneo para expressão de $\mathrm{p} 53$.

5. DISCUSSÃO. 155

5.1 P53, XPC, Reparo de DNA e Melanoma: Como p53 pode influenciar a atividade de reparo de DNA e sensibilidade à UVB e cisplatina.

5.2 Relação de hHR23B com o desenvolvimento de melanoma e sua atividade na modulação de XPC

5.3 Expressão alelo-específica de XPC e sua influência na modulação na atividade gênica .184

5.4 Função dos agentes modificadores da via GGR-NER na resposta à UVB, na atividade de XPC e na resposta ao tratamento com o quimioterápico cisplatina em melanomas: Visão geral e integrativa de processos.

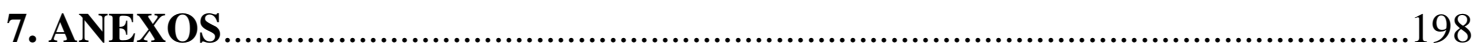

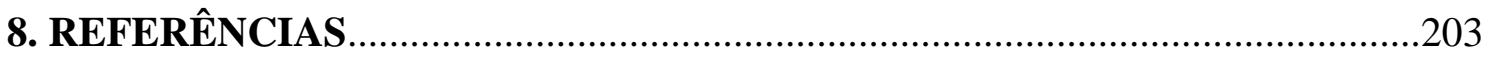




\section{Lista de Abreviaturas}

\begin{tabular}{|c|c|}
\hline$\mu \mathbf{l}$ & microlitro \\
\hline$\mu \mathrm{Ci}$ & micro Curie \\
\hline$\mu \mathbf{W}$ & micro Watt \\
\hline bp & base pairs \\
\hline BSA & Bovine serum albumin \\
\hline $\mathbf{C}$ & citosina \\
\hline CDKN2A & cyclin-dependent kinase inhibitor $2 \mathrm{~A}$ \\
\hline cDNA & complementary DNA \\
\hline CPD & cyclobutane pyrimidine dimer \\
\hline CpG & Sítio Citosina seguido de Guanina \\
\hline CSB & Cockayne Syndrome B \\
\hline DDB-2 & DNA Damage binding protein 2 \\
\hline DMSO & dimetilsulfóxido \\
\hline dNTPs & deoxy-nucleotídeos (ATP, CTP, GTP, TTP) \\
\hline DTT & Dithiothreitol \\
\hline EDTA & ácido etilenodiamino tetra-acético \\
\hline hHR23B & human homologue RAD23 B \\
\hline $\mathbf{J}$ & Joule \\
\hline $\mathbf{K b}$ & quilobase \\
\hline $\mathbf{k} \mathbf{V}$ & Kilo volts \\
\hline $\mathbf{M}$ & Molar \\
\hline $\mathbf{m}^{2}$ & metro quadrado \\
\hline $\operatorname{Mdm2}$ & mouse double minute 2 \\
\hline $\mathrm{MgCl}_{2}$ & Cloreto de magnésio \\
\hline mHR23 & murine homologue RAD23 \\
\hline ml & mililitro \\
\hline $\mathbf{m M}$ & milimolar \\
\hline MMP-1 & Matrix Metalloproteinase-1 \\
\hline ng & nanograma \\
\hline $\mathbf{n m}$ & nanometro \\
\hline
\end{tabular}




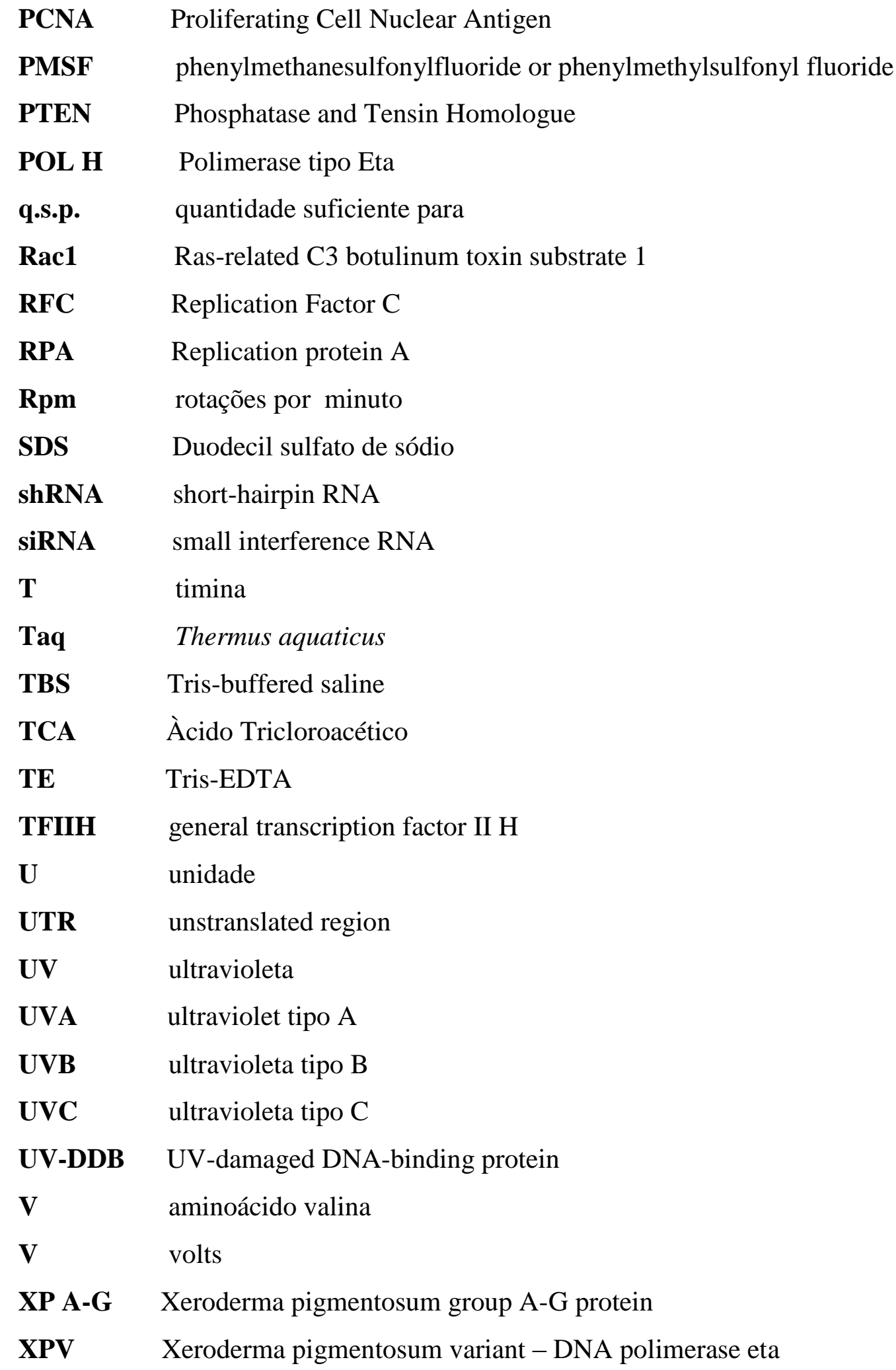




\section{Listas de Figuras}

Figura 1 - Formação de dímeros de ciclobutano (CPD) e fotoprodutos 6-4 entre bases adjacentes no DNA após radiação UVB.

Figura 2 - Via de reparo por excisão de Nucleotídeos (NER) ............................................................

Figura 3 - Esquema representativo da análise de ciclo celular através de um histograma.......................32

Figura 4 - Sensibilidade das linhagens Skmel-28 e Skmel-37 à UVB................................................64

Figura 5 - Western Blotting para XPC, XPV e DDB-2 em Skmel-28 e Skmel-37 após UVB..................65

Figura 6 - Ensaio de Recuperação de RNA nas linhagens Skmel-28, Skmel-37 e CSB..........................67

Figura 7 - Dot-Blot para reparo de lesões do tipo CPD em Skmel-28 e Skmel-37...............................67

Figura 8 - Contagem do número de foci para fosfo-H2AX em Skmel-28 e Skmel-37 após UVB.............68

Figura 9 - Western Blotting para p53, p21 e fosfo-ERK em Skmel-28 e Skmel-37 após exposição à UVB..

Figura 10 - Morte celular em Skmel-28 e Skmel-37 após 48h de exposição à UVB e uso de pifithrin- $\alpha . .70$

Figura 11 - Morte Celular de Skmel-28 transfectada para expressar p53 e seu respectivo controle (Mock) após $48 \mathrm{~h}$ de exposição à UVB..... ..71

Figura 12 - Western Blotting para XPC, XPV e p53 em Skmel-28 transfectada com vetor para expressão de p53 e seu controle (Mock).

Figura 13 - Cinética de reparo de lesões CPD em linhagem Skmel-28 transfectada com vetor viral para expressão de p53 e controle (Mock).

Figura 14 - Western blotting para expressão de PUMA $\alpha / \beta$, BAD e BCL-2 em Skmel-28 e Skmel-37 após UVB.

Figura 15 - Ensaios de ativação de Caspase 3/7 após exposição à UVB (120 J/m²) em Skmel-28 e Skmel37

Figura 16 - Western Blotting para Beclin-1 e LC-3 após UVB em Skmel-28 e Skmel-37. .75

Figura 17 - Ensaios de detecção de ROS após exposição à UVB (120 J/m²) em Skmel-28 e Skmel-37....77

Figura 18 - Ensaios de detecção de ROS após exposição à UVB (120 J/m²) em Skmel-28 transduzida....78

Figura 19 - Análise de morte celular após UVB utilizando-se Catalase e Tempol.

Figura 20 - Imagem representativa das lesões de origem melanocíticas analisadas por TMA (aumento de $5 \mathrm{x})$.

Figura 21 - Imagem representativa das lesões de origem melanocíticas analisadas por TMA (aumento de 20x). .82

Figura 22 - Análise da porcentagem de células positivas para hHR23B. . .83 
Figura 23 - Resultado obtido por real-time PCR para avaliação da diferença de expressão entre hHR23A e hHR23B em linhagens de melanoma

Figura 24 - Expressão de hHR23A e hHR23B nas linhagens de melanoma. .86

Figura 25 - Expressão de hHR23B em linhagens de melanoma humanas e murinas, representativas de diferentes fases da progressão de melanoma. . .87

Figura 26 - Expressão de hHR23B nas linhagens LB373 e Mel85 após tratamento com $10 \mu \mathrm{M}$ de 5’Aza2'-deoxicitidina. .88

Figura 27 - Morte celular após UVB. (A) \% de células hipodiplóides medida por incorporação de PI....90

Figura 28 - Ensaio de recuperação de RNA nas linhagens de melanoma e na linhagem CSB após irradiação com diferentes doses de UVC.

Figura 29 - Cinética de reparo de lesões do tipo fotoproduto 6-4PP e lesões do tipo CPD .93

Figura 30 - Expressão de XPC nas linhagens de melanoma após UVB .94

Figura 31 - Estabilidade de XPC nas linhagens de melanoma após tratamento com $40 \mu \mathrm{M}$ de CHX.........95

Figura 32 - Expressão de DDB-2 e p53 nas linhagens de melanoma após UVB. . .96

Figura 33 - Estabilidade de p53 nas linhagens de melanoma após tratamento com cicloheximida .96

Figura 34 - Imuno-colocalização de hHR23B e XPC na linhagem Skmel-37. . .98

Figura 35 - Uso de esiRNA para hHR23B .99

Figura 36 - Uso de esiRNA para XPC.

Figura 37 - Estabilidade e expressão de XPC. Estabilidade de XPC após uso de esiRNA para hHR23B e CHX por 3h (A). Expressão de XPC após esiRNA para hHR23B e irradiação com UVB. 101

Figura 38 - Dot-Blot para reparo de lesões do tipo fotoproduto 6-4 (6-4PP) 103

Figura 39 - Dot-Blot para reparo de lesões do tipo CPD 104

Figura 40 - Sensibilidade de células Skmel-37 após uso de esiRNA para hHR23B e XPC 105

Figura 41 - Sensibilidade das linhagens de melanoma à doxorrubicina. 108

Figura 42 - Sensibilidade das linhagens de melanoma à 5’Fluoracil, Etoposídeo, Temozolomida, Cisplatina e Tunicamicina, após silenciamento de hHR23B e XPC. 110

Figura 43 - Genotipagem das linhagens celulares de melanoma existentes no laboratório para os polimorfismos de $X P C$

Figura 44 - Genotipagem das novas linhagens celulares de melanoma existentes no laboratório para os polimorfismos de $X P C$

Figura 45 - Amplificação de DNA contaminante em amostras de RNA extraído do ensaio para quantificação alelo-específica de XPC.

Figura 46 - Genotipagem de amostras do banco de DNA para posterior teste de reação cruzada. 120 
Figura 47 - Plot de identificação de genótipos por Taqman

Figura 48 - Amplification e Multicomponent plots a partir da amplificação de amostras de genótipo conhecido através do ensaio Taqman.

Figura 49 - Amplification plots para a curva de amplificação da curva padrão

Figura 50 - Plotagem dos dados da curva padrão.

Figura 51 - Análise de expressão de XPC e expressão alelo-específico de XPC K939Q em Skmel-02...126

Figura 52 - Análise de expressão de XPC e expressão alelo-específico de XPC K939Q em Skmel-37...127

Figura 53 - Análise de expressão de XPC e expressão alelo-específico de XPC K939Q em MZ2-Mel...128

Figura 54 - Análise de expressão de XPC e expressão alelo-específico de XPC K939Q em LB-373......129

Figura 55 - Análise de expressão de XPC e expressão alelo-específico de XPC K939Q em Skmel-147.130

Figura 56 - Controle negativos para ensaio de Taqman para K939Q

Figura 57 - Controle negativos para ensaio de Taqman para K939Q

Figura 58 - Sensibilidade das linhagens Skmel-28 e Skmel-37 a diferentes doses de cisplatina.....

Figura 59. Ensaio clonogênico de sobrevivência

Figura 60 - Western Blotting para p53, p21 e fosfo-ERK para Skmel-28 e Skmel-37 após exposição à cisplatina.

Figura 61 - Western Blotting para expressão de XPC, fosfo-H2AX e ERCC1.

Figura 62 - Morte celular em Skmel-28 e Skmel-37 após o uso de pifithrin- $\alpha$

Figura 63 - Análise do efeito do ciclo celular na resposta à cisplatina

Figura 64 - Western Blotting para BCL-2 e PUMA $\alpha / \beta$

Figura 65 - Análise da ativação de Caspase 3/7.

Figura 66 - Western Blottings da expressão de XPC, p53 e PUMA $\alpha / \beta$ na linhagem Skmel-28 transduzida com $\mathrm{p} 53$ e GFP. 146

Figura 67 - Morte celular em Skmel-28 transduzidas para expressar p53 e GFP 147

Figura 68 - Morte celular em Skmel-28 e Skmel-37 após cisplatina e Nutlin-3 148

Figura 69 - Ensaio de sobrevivência por formação de colônias em Skmel-28 e Skmel-37 .148

Figura 70 - Western Blotting para p53 e PUMA $\alpha / \beta$.

Figura 71 - Morte celular após cisplatina utilizando-se siRNA para XPC

Figura 72 - Histogramas obtidos para o ensaio com componente heterogêneo de populações expressando p53 ou GFP.....

Figura 73 - Gráfico mostrando a proporcionalidade das subpopulações de Skmel-28 transduzidas com GFP e p53 após exposição à cisplatina conforme os tempos determinados 


\section{Listas de Tabelas}

Tabela 1 - Primers, condições de PCR e restrição para os polimorfismos de XPC......

Tabela 2 - Cálculo da diluição das amostras controle utilizadas na curva-padrão para os ensaios de análise de expressão alelo-específica

Tabela 3 - Frequência genotípica e risco associado a polimorfismos no gene $X P C$ e risco de melanoma.

Tabela 4 - Associação de variações polimórficas de XPC e demais fatores de risco para o risco de desenvolvimento de melanomas.............................................................................................113

Tabela 5 - Resumo da genotipagem dos polimorfismos de XPC nas linhagens de melanoma. .117 


\section{RESUMO}

Francisco G. Eixo p53-hHR23B-XPC na modulação das vias de reparo de DNA em melanomas: Evidências para processos de carcinogênese, progressão $e$ quimioresistência [Tese]. São Paulo: Faculdade de Medicina, Universidade de São Paulo; 2014.

O reparo de lesões genômicas tem papel critico na supressão da transformação maligna. Para melanomas, tipo de câncer de pele, lesões causadas por UV são responsáveis pela aquisição do fenótipo maligno. A via de reparo por excisão de nucleotídeos (NER) exerce função importante na correção destas lesões, sendo na proteína XPC um dos seus principais agentes atuantes no reconhecimento das lesões. Enquanto mutações em XPC predispõem à Xeroderma Pigmentosum, modulações na função de XPC podem exercer papel critico na aquisição de mutações UV em melanomas esporádicos. A modulação pode ocorrer por ação transcricional, interação proteica ou também por fatores genéticos que possam interferir com sua expressão e/ou atividade. Para entender o papel da transcrição na modulação do reparo exercido por XPC, verificou-se o papel de p53 neste contexto. Comparando-se linhagens com diferentes status funcionais de p53 frente a lesões UVB, os resultados indicaram seu papel quanto a diferenças na sensibilidade à exposição, expressão de proteínas de reparo e cinética de reparo de lesões CPD. Além disso, caracterizou-se a expressão de proteínas envolvidas com apoptose e a ativação de caspase $3 / 7$, além da expressão de espécies reativas de oxigênio produzidas após UVB, as quais sugeriram um efeito prósobrevivência após neutralização destas moléculas. Com relação à modulação de XPC quanto a seu principal partner, hHR23B, procurou-se verificar seu papel na biologia de melanomas. Análise da expressão de hHR23B em amostras de tecido de séries névicas, melanomas primários e metástases, demonstrou grande heterogeneidade de marcação 
principalmente em nevus e melanomas primários. Dados apresentados demonstraram que hHR23B esta relacionado à estabilidade e acúmulo de XPC, consequentemente alterando a eficiência de reparo de DNA para lesões UVB. O silenciamento de hHR23B modulou a morte celular após UVB de maneira a diminuir sua taxa, porém a longo prazo, tal sobrevivência não foi evidenciada. O silenciamento de hHR23B também afetou a sensibilidade à alguns agentes quimioterápicos. Para os possíveis efeitos genéticos na modulação de XPC, verificou-se o papel de polimorfismos genéticos existentes no gene. Análise de expressão alelo-específica do polimorfismo K939Q não sugeriu diferenças na expressão relacionadas a estas variantes polimórficas. Por fim, verificou-se o papel que p53 e NER poderiam exercer sobre a resposta à cisplatina. Usando as mesmas linhagens utilizadas para a resposta à UVB, verificou-se que, ao contrário, células possuindo atividade funcional de p53 apresentavam maior sensibilidade ao quimioterápico. Esta sensibilidade não se mostrou relacionada diretamente a expressão de proteínas de reparo como XPC e ERCC1, embora XPC tenha demonstrado estar relacionado à sensibilidade quando do uso de siRNA. Além disso, a restauração da atividade de p53 seja por uso de vetores virais ou através de inibidores de HDM-2 como Nutlin-3, demonstraram-se eficazes no intuito de aumentar a sensibilidade ao quimioterápico. Em conjunto, os resultados apresentados evidenciam o papel de diferentes fatores que possam modular a atividade de reparo de DNA frente à UVB e quimioterápicos, principalmente no que se refere ao eixo p53-hHR23B-XPC, pontuando-os como peças importantes na compreensão da biologia de melanomas em processos de carcinogênese, progressão e quimiorresistência. 


\begin{abstract}
Francisco G. p53-hHR23B-XPC axis modulates DNA repair pathways in melanomas: Evidences to carcinogenesis, progression and chemoresistance process [Thesis]. São Paulo: Faculdade de Medicina, Universidade de São Paulo; 2014.
\end{abstract}

The repair of genomic lesions plays a critical role in the suppression of malignant transformation. For melanoma, a type of skin cancer, lesions caused by UV are responsible for the acquisition of the malignant phenotype. The nucleotide excision repair (NER) pathway has an important role in the repair of these lesions and XPC protein in one of its main active agents in lesion recognition. While mutations in XPC predispose to Xeroderma Pigmentosum, modulations in XPC function may play critical role in the acquisition of UV mutations in sporadic melanomas. The modulation may occur either by transcriptional activity, protein interaction or also by genetic factors that may interfere with their expression and / or activity. To understand the role of the transcription in modulating the DNA repair exerted by XPC, we verified the role of p53 in this context. Comparing cells lines with different p53 functional status after UVB injury, the results indicated its role regarding the differences in sensitivity, expression of repair proteins and DNA repair kinetics of CPD lesions. Moreover, we characterized the expression of proteins involved in apoptosis and the activation of caspase $3 / 7$, besides the analysis of the expression of reactive oxygen species produced after UVB exposure. Such molecules suggested a pró-survival effect after UVB exposure due to results observed after neutralization. Regarding the modulation of XPC by its main partner, hHR23B, we verified its role in the biology of melanoma. HHR23B expression analysis in tissue samples series of nevus, primary melanoma and metastases showed critical heterogeneity stainning, especially in nevi and primary melanomas samples. Results 
indicated that hHR23B play a role in XPC stability and accumulation, altering the efficiency of DNA repair to UVB injury. Knocking-down of hHR23B by siRNA modulated cell death after UVB by decreasing its rate, but the long-term survival has not been demonstrated so. The knocking-down of hHR23B also affected sensitivity to some chemotherapeutic agents. Regarding the possible genetic effects in the XPC modulation, we verified the role of existing genetic polymorphisms inside the gene. Analysis of allele-specific expression of K939Q polymorphism did not suggest differences in expression related to these polymorphic variants. Finally, it was tested that the role p53 and NER may have on the response to cisplatin. Using the same cell lines used for the response to UVB, it was found that, in contrast, cells having functional activity of p53 showed greater sensitivity to chemotherapy. This sensitivity was not directly related to expression of DNA repair proteins such as XPC and ERCC1, although XPC has shown to be related to the sensitivity when using siRNA. In addition, the restoration of p53 activity by use of viral vectors or by HDM-2 inhibitors, such as nutlin-3, proved to be effective in order to increase the sensitivity to chemotherapy. Overall, the results demonstrate the role of different factors that may modulate the activity of DNA repair against UVB and chemotherapy, especially with regard to p53hHR23B-XPC axis, selecting them as major players in the understanding of the melanoma biology regarding the processes of carcinogenesis, progression and chemoresistance. 


\section{INTRODUÇÃO}

\subsection{Desenvolvimento de Melanomas: Papel da Radiação UV}

O Melanoma é, dentre os casos de câncer de pele, o de menor incidência, porém com a maior taxa de letalidade. Isto porque apresenta um comportamento agressivo, normalmente produzindo metástases. Este tipo de neoplasia origina-se dos melanócitos da pele, os quais têm origem embrionária a partir da crista neural. Estas células exercem a importante função de determinar a resposta da pele frente à exposição à radiação ultravioleta (UV) e representam cerca de 8 a $10 \%$ das células epidermais. Sua função está em promover a síntese de melanina através da foto estimulação por UV e assim conferir pigmentação à pele, pigmentação esta que possui um importante efeito de foto proteção.

Com relação à ação protetora do melanócito, a melanina (mais precisamente a eumelanina) é o pigmento que possui a habilidade de servir como uma barreira física que espalha o UV incidente e como um filtro reduz sua penetração na epiderme (Slominski et al., 2004). Contudo, os melanócitos são células que possuem diversos fatores pró-sobrevivência e antiapoptóticos, e que durante exposições intensas e intermitentes tais células recebem grandes doses de radiação UV sem proteção da síntese aumentada de melanina. Estes dois fatores, portanto, possibilitam aos melanócitos receberem intensa quantidade de luz UV mutagênica e mesmo assim consigam sobreviver (Perlis \& Herlyn, 2004). Nestes casos onde os melanócitos adquirem mutações e outros danos lesivos ao DNA é que o processo carcinogênico pode ser iniciado.

Um dos principais efeitos do UV no desenvolvimento do câncer está no dano direto ao DNA. Absorção do UVB pelo DNA pode levar a dois tipos de lesões: os 
fotoprodutos 6-4, gerados entre resíduos de pirimidinas adjacentes, e por dímeros de pirimidinas ou ciclobutanos, formados especificamente por resíduos adjacentes de timina ou citosina (Figura 1). Os dímeros de pirimidina são formados entre duas pirimidinas adjacentes; as duplas ligações se tornam saturadas formando um anel de quatro membros (Matsumura \& Ananthaswamy, 2002). Já os fotoprodutos 6-4 se formam entre a posição seis e a posição quatro de duas pirimidinas adjacente, mais frequentemente entre resíduos de TC e CC. Dímeros de pirimidina são considerados mais carcinogênicos que fotoprodutos $6-4$, formando-se cerca de três vezes mais e sendo menos eficientemente reparados. (Pfeifer et al., 2005). Ambos os tipos de lesão podem levar a mutações genéticas tais como transições $\mathrm{C} \rightarrow \mathrm{T}$ e $\mathrm{CC} \rightarrow \mathrm{TT}$, este último característico de lesão por UV.

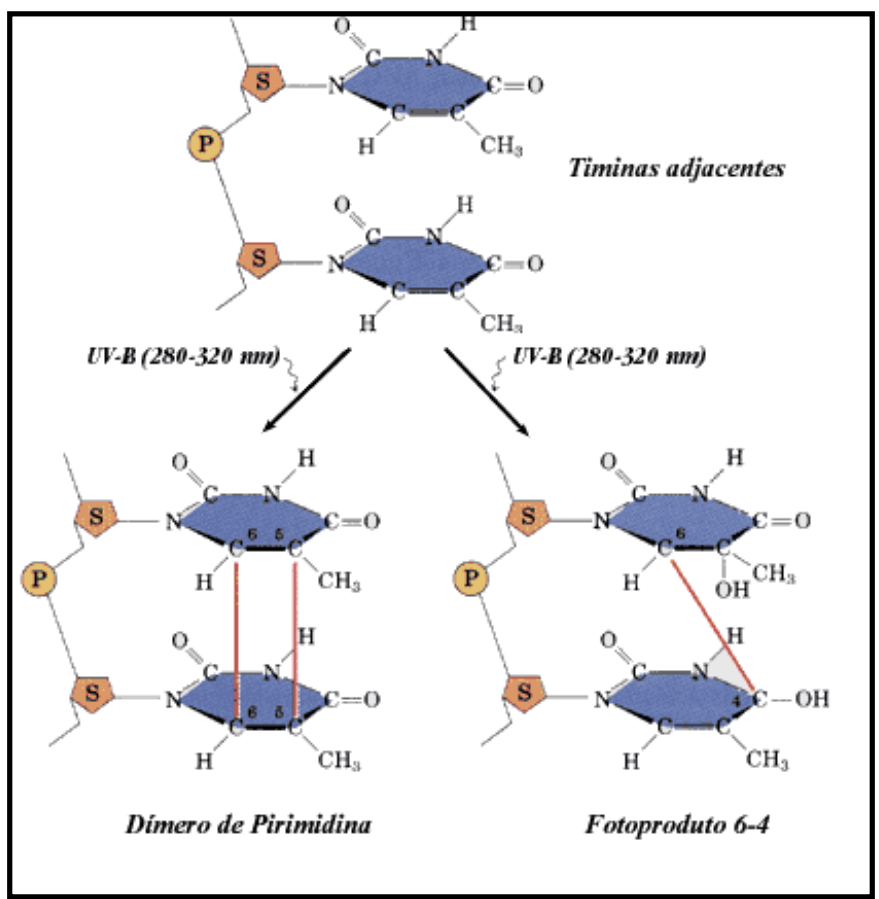

Figura 1 - Formação de dímeros de ciclobutano (CPD) e fotoprodutos 6-4 entre bases adjacentes no DNA após radiação UVB. Fonte: Modificado de Despommier e Chen (2004). 
Contudo, não apenas fatores ambientais estão associados ao desenvolvimento de melanoma. Fatores genéticos também apresentam grande relevância para o processo de carcinogênese deste tipo de neoplasia. Mutações no locus gênico CDKN2A, o qual codifica proteínas responsáveis pela regulação do ciclo celular, são responsáveis em grande parte pelo aparecimento de casos de melanoma sejam esporádicos ou familiares, sendo tais mutações amplamente descritas na literatura. Outros genes de grande importância seriam os genes que compõe o sistema de reparo do DNA. Isto porque, uma vez que a luz UV causa mutações carcinogênicas, a correção destes danos contribuiria enormemente para a supressão de um possível processo de desenvolvimento de melanoma. Estes genes possuem diversas funções e vias de sinalizações que garantam sua eficácia, desde o reconhecimento da lesão, recrutamento das enzimas responsáveis, passando por processamento dos danos e a parada do ciclo celular (Costa et al., 2003). Mutações inativadoras destas enzimas são responsáveis por alguns tipos de doenças, entre elas o Xeroderma Pigmentosum, a qual predispõe os indivíduos afetados a uma probabilidade 1000 vezes maior de desenvolver tumores cutâneos (Budden \& Bowden, 2013).

De fato, recentes dados da literatura reforçam o papel de lesões UV no desenvolvimento de melanomas. Isto porque mutações típicas de exposição ao UV têm sido encontradas no genoma de melanomas. Recentemente, o estudo de Pleasance e colaboradores (Pleasance et al., 2010) sequenciou o genoma inteiro de uma linhagem celular originada de um melanoma metastático, enquanto o estudo conduzido por Berger e colaboradores (Berger et al., 2012) sequenciou o genoma de 25 melanomas metastáticos, ambos estudos com o intuito de catalogar as mutações somáticas ocorridas. Estudos adicionais também se utilizaram de sequenciamento em larga escala 
para identificar mutações especificas em regiões codificadoras do genoma (exoma) de melanomas, onde aproximadante 150 amostras foram sequenciadas (Krauthammer et al., 2012). Em todos os estudos citados, a maioria das mutações presentes foi de substituições de $\mathrm{C} \rightarrow \mathrm{T}$ e $\mathrm{CC} \rightarrow \mathrm{TT}$. Posteriores análises destes dados indicaram que a maioria destas substituições ocorreu em regiões contendo pirimidinas adjacentes, sítios de maior frequência de ocorrência de desenvolvimento de fotoprodutos. Além disso, a frequência das substituições foi mais elevada em sítios $\mathrm{CpG}$, os quais são mais susceptíveis a formação de lesões CPD devido a metilação de citosinas e também em regiões não-transcritas do genoma. Desta maneira, o espectro de mutações recémcatalogadas em melanomas demonstra que a maioria das mutações somáticas neste tipo de neoplasia cutânea é resultado de danos causados por exposição à luz UV. Contudo, a real função que tais mutações exercem no desenvolvimento de melanomas ainda é objeto de estudo de diversas pesquisas.

Interessantemente, as mutações mais comuns encontradas em genes relacionados ao desenvolvimento de melanomas $(B R A F, N R A S)$ não apresentam mutações típicas de UV. No entanto, o gene PTEN cuja frequência de mutações em melanomas apresenta um percentual de 30 a 40\%, em indivíduos identificados como portadores da síndrome de Xeroderma Pigmentosum a taxa de mutações em PTEN nos melanomas destes pacientes foi de $56 \%$, onde $91 \%$ destas mutações foram de mutações típicas de UV (Wang et al., 2009). Neste estudo em especifico, os dados evidenciaram uma função mais especifica de mutações do tipo UV na progressão de melanomas. Estudos mais recentes de sequenciamento de Exoma em melanomas identificaram mutações no gene RACl com forte evidência de alterações típicas de UV (Krauthammer et al., 2012). Estudos funcionais indicaram que expressão de formas mutantes de $R A C 1 \mathrm{em}$ 
melanócitos aumentou a proliferação e migração destas células, sugerindo que mutações neste gene possam contribuir com a proliferação celular (Krauthammer et al., 2012).

Todos estes recentes achados têm dado suporte para o importante papel de mutações UV no desenvolvimento de melanomas. Baseado no conhecimento de que indivíduos que apresentam mutações em genes de reparo de DNA (mais precisamente em indivíduos Xeroderma Pigmentosum) apresentam maior susceptibilidade ao desenvolvimento de tumores cutâneos, incluindo melanomas, os recentes achados nos sugerem que alterações ou mesmo falhas no processo de reparo de DNA podem facilitar a aquisição de mutações do tipo UV potencialmente carcinogênicas para a transformação maligna dos melanócitos em melanomas. Assim, o estudo do papel do sistema de reparo de DNA em melanócitos/melanomas pode contribuir para o conhecimento dos processos envolvidos na aquisição de mutações UV, principalmente com relação aos padrões de exposição solar de risco.

1.2 Contrabalanceando os efeitos da Radiação UV: Genes e Sistema de Reparo de DNA

A absorção da energia da radiação UVB pelo DNA pode gerar dímeros de pirimidina (CPDs) e fotoprodutos 6-4, os quais são capazes de induzir mutações ou até mesmo double strand breaks se não forem reparados corretamente. Estes tipos de lesões, ao lado dos adutos de DNA, são preferencialmente reparados pela via de reparo por excisão de nucleotídeos (NER- nucleotide excision repair) (Costa et al. 2003). Existem diferentes enzimas atuando na via do NER, sendo a maioria delas descrita a partir de estudos realizados com linhagens celulares contendo mutações em tais genes, linhagens estas originadas a partir de pacientes com síndromes relacionadas com deficiência no sistema de reparo como, por exemplo, o Xeroderma Pigmentosum (XP) e 
Sindrome de Cockayne (CS). Estas proteínas foram nomeadas de acordo com seu específico grupo de complementação, sendo sete grupos identificados para XP (XPAXPG) e duas para CS (CSA e CSB). Existe ainda um oitavo grupo de complementação para pacientes XP, denominado de XPV que é decorrente de mutações no gene da DNA polimerase eta. Tal polimerase é recrutada durante a replicação do DNA em situações onde a fita molde contenha dímeros de timina induzidos por UV (Masutani et al., 1999), não foram devidamente corrigidos pela maquinaria de reparo, sendo portanto responsável pela correta incorporação de nucleotídeos adenina, neutralizando as possíveis mutações causadas pelo fotoproduto.

Existem duas sub-vias em NER. Primeiramente o GGR-NER (global genomic repair - NER) que opera ao longo do genoma, enquanto o TCR-NER (transcriptioncoupled repair - NER) atua na remoção de lesões nas fitas transcritas de genes ativos (Nouspikel, 2009) (Figura 2). A maior diferença entre estas duas sub-vias de reparo via NER tem sido atribuída aos passos envolvidos no processo de reconhecimento das lesões, bem como na eficiência de reparo de cada uma destas vias (Sugasawa, 2006). No TCR-NER, o bloqueio do processo de elongação da transcrição pela parada da RNA polimerase II (pol II), frente à presença de lesões no DNA da fita transcrita, é tido como o processo no qual a lesão pode ser percebida e reconhecida, onde o posterior recrutamento de CSB e eventualmente outras proteínas acaba disparando a reação de reparo (Sarasin \& Stary, 2007). Contudo, os passos exatos de reconhecimento da lesão e recrutamento de proteínas para o sitio de parada da RNA pol II, continuam não totalmente esclarecidos. Quanto à eficiência de reparo, TCR-NER tem demonstrado operar mais rapidamente no reparo de lesões UV do que em relação ao GGR-NER (Hanawalt, 2002). 


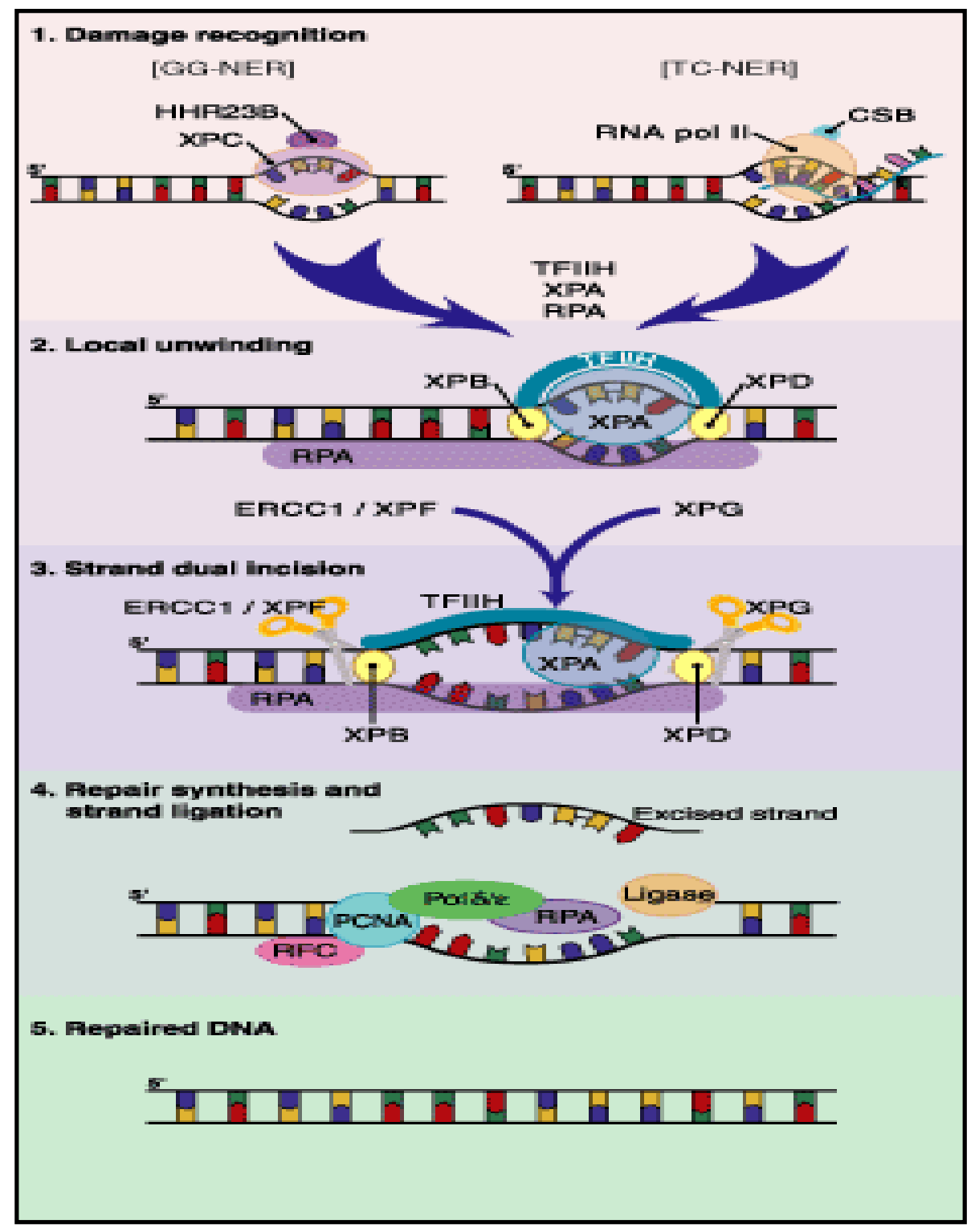

Figura 2. Via de reparo por excisão de Nucleotídeos (NER). A figura mostra os dois braços da via NER: o reparo genômico global (GGR), que atua em todo o genoma, principalmente em regiões não transcritas; e o reparo acoplado à transcrição (TCR), o qual atua em regiões transcritas do genoma. No GGR, o reconhecimento da lesão ocorre pelas proteínas XPC-hHR23B. Já no TCR, o reconhecimento da lesão acontece com o bloqueio da RNA polimerase e conseqüente atuação de proteínas como CSA e CSB. Fonte: R\&D systems (2003).

Por outro lado, em GGR-NER, as lesões são reconhecidas por proteínas que tem afinidade ao DNA e que, além disso, possuem específica afinidade por sítios danificados (Sugasawa, 2006). Um complexo contendo a proteína XPC exerce função essencial neste processo. XPC, juntamente com as proteínas hHR23B e centrina-2, é 
responsável pela ligação e reconhecimento de lesões. No entanto, análises bioquímicas revelaram que o complexo, mais precisamente XPC, não reconhece lesões baseando-se nos tipos específicos de lesões, mas sim a distorção que estas lesões causam na estrutura do DNA (Sugasawa et al. 2002). Portanto, uma vez que a lesão induz distorções na dupla hélice do DNA, XPC pode se ligar ao sitio independente da estrutura da lesão. No complexo, hHR23B protegeria XPC contra degradação proteassomal (Ng et al. 2003), enquanto centrina-2 atuaria para reforçar a afinidade de XPC ao DNA (Nishi et al. 2005). No caso de lesões causadas por UV, os fotoprodutos 6-4, devido à maior distorção que ocasionam no DNA, podem ser prontamente reconhecidos por XPC, enquanto os dímeros de pirimidina (CPD), induzem pouca distorção na dupla hélice, o que leva XPC a possuir menor afinidade a esta lesão (Sugasawa et al. 2001), contudo o reparo deste tipo de lesão ainda é dependente de XPC. Este fato pode ser uma das explicações do motivo dos CPDs serem mais carcinogênicos do que os fotoprodutos 64, justamente por serem menos eficientemente reconhecidos por XPC. Para o reparo de CPDs, o funcionamento de proteínas UV-DDB (UV damage DNA-binding)(mais precisamente DDB-2), as quais são mutadas em paciente XP-E, são importantes no reconhecimento destas lesões, facilitando posteriormente a ligação de XPC ao sítio contendo CPDs.

Após reconhecimento da lesão, seja via XPC no GGR ou pela parada da RNA pol II e CSB no TCR, os subsequentes processos de reparo envolvem mecanismos em comum (Figura 2). O recrutamento da maquinaria responsável pelo reparo começa com a ligação do fator de transcrição TFIIH, o qual é composto por nove subunidades sendo que as proteínas XPB e XPD sub-componentes deste complexo. XPB e XPD exibem função já reconhecida no NER, devido a suas atividades ATPase e helicase (Weeda et 
al. 1990). Desta maneira, XPB e XPD iniciam a abertura da dupla fita permitindo a chegada das outras enzimas envolvidas. Em seguida ocorre a chegada de XPA e RPA junto ao complexo. XPA é uma proteína com grande afinidade ao DNA lesado e interage tanto com TFIIH quanto RPA (Stigger et al. 1998). Já RPA parece estar envolvida em assessorar o processo de pré-incisão da fita lesada, além de recrutar os fatores de replicação para a síntese do DNA reparado (Kolpashuchikov et al. 2001). Após a montagem desta maquinaria, são recrutadas as proteínas XPF-ERCC1 e XPG, as quais apresentam atividade endonuclease 5' e 3', respectivamente. Uma vez feita a incisão da fita originalmente lesada, o próximo passo consiste em preencher o gap existente. Neste momento, provavelmente toda a maquinaria deixa o DNA, restando apenas RPA, que é requerida para este processo de preenchimento. São recrutadas então DNAs polimerases e mais os co-fatores PCNA e RFC via RPA. A síntese de DNA é refeita e por fim, a DNA Ligase I termina o processo ao restabelecer as ligações fosfodiéster.

\subsection{Papel da via NER na biologia de Melanomas}

A função dos sistemas de reparo de DNA na supressão de tumores pode ser observada em síndromes que predispõe ao aparecimento de câncer onde são observadas mutações hereditárias em genes de reparo de DNA. Mutações na via de reparo NER, a qual atua na correção de lesões causadas por exposição à luz UV, condicionam à síndrome do Xeroderma Pigmentosum, onde os indivíduos afetados apresentam cerca de 1000 vezes mais chance de desenvolver tumores cutâneos antes dos 20 anos, incluindo melanomas (DiGiovanna \& Kraemer, 2002), quando comparados à indivíduos normais. Melanomas em indivíduos portadores da síndrome de XP têm sido descritos em 
diferentes estudos que abordam os diferentes grupos de complementação da doença, sendo estes os grupos do tipo XP-A (Wang et al., 2009); XP-C (Spatz et al., 2001; Jacobelli et al., 2008; Wang et al., 2009; Hadj-Rabia et al., 2013), XP-D (Bradford et al., 2011); XP-V (Spatz et al., 2001; Opletalova et al., 2014). De fato, os resultados de sequenciamento em larga escala tem demonstrado que falhas no sistema de reparo tem contribuído para a aquisição de mutações carcinogênicas do tipo UV. Diversos estudos buscam entender em que passos do sistema de reparo acontecem as falhas que podem levar a aquisição de mutações carcinogênicas as quais contribuem para a transformação maligna dos melanócitos.

Os melanócitos podem, inicialmente, ter uma capacidade de reparo via NER menor quando comparado com outros tipos de células (Wang et al., 2010). A capacidade de reparo frente a danos oxidativos e fotoprodutos em melanócitos, fibroblastos normais e células XP foram comparados em ensaios in vitro. A capacidade dos melanócitos em reparar tais tipos de lesão foi menor do que os resultados apresentados para fibroblastos normais, mas não tão baixo quanto aos demonstrados por células XP. O estudo também demonstrou que a presença de melanina poderia interferir no processo de reparo das lesões, uma vez que quando adicionada de maneira exógena, alterava a capacidade de reparo de maneira proporcional à quantidade de melanina. Esta evidência sugere que a melanina em melanócitos pode se liga ao DNA e assim interferir com o reconhecimento de danos, resultando na redução da eficiência de reparo. Os resultados obtidos neste estudo podem explicar o percentual reduzido de reparo de lesões CPD e 6-4 PP em ambos os melanócitos e células de melanoma relatado por outro trabalho (Gaddameedhi et al., 2010). Em seu trabalho Gaddameedhi e colaboradores (2010) compararam a taxa de reparo entre melanócitos e melanomas e 
relataram nenhuma diferença na capacidade de reparo entre as células, levando os autores a sugerir que a aparente não diminuição da capacidade da via NER em melanomas indicasse pouca participação desta via para a gênese desta neoplasia.

No entanto, se os melanócitos originalmente têm uma baixa capacidade de reparo (segundo Wang et al., 2010), então a falta de diferença entre melanócitos e células de melanoma não pode descartar a via NER desempenhando um papel de desenvolvimento de melanoma. Ter uma baixa capacidade da via NER pode predispor melanócitos ao acúmulo de mutações no DNA induzidos por UV, as quais podem iniciar o processo de carcinogênese.

O sequenciamento do genoma de linhagens de melanoma (Pleasance et al., 2010; Berger et al., 2012) mostrou uma assinatura mutacional desigual no genoma. Houve uma menor prevalência de mutações UV em regiões transcritas, bem como dentro de exons em comparação com íntrons. Isto sugere que a via TCR-NER ainda é funcional em melanomas. Por outro lado, alterações na atividade de GGR-NER podem ser responsáveis pela quantidade significativa de mutações UV observadas em todo o resto do genoma, mais precisamente em regiões não-transcritas. Em particular, a via de GGR-NER pode ser importante, uma vez que esta via funciona para reparar os danos que podem levar a mutações durante a replicação do DNA, e os pacientes $X P$ (principalmente pacientes XP-C devido a sua maior frequencia) com defeito em GGRNER tem uma forte associação com o desenvolvimento de câncer. Apesar desta possível conexão entre NER e melanoma, poucas pesquisas nessa área tem sido feito. Dada a escassez de pesquisa em NER em melanoma, mais estudos são necessários para elucidar completamente esta relação. 
Além de mutações nos genes da via NER que caracterizam indivíduos XP, variações genéticas em genes de reparo também podem estar envolvidas. De fato, existem diferentes variantes polimórficas nos genes que compõe o sistema de reparo NER, os quais têm sido ou não atribuídos a maior susceptibilidade ao desenvolvimento de melanoma. Variantes polimórficas em genes como $X P C, X P D, X P G$ e $X P V$ têm demonstrado associações positivas com o desenvolvimento de melanomas, sugerindo possíveis contribuições destas variações no desenvolvimento de melanomas (revisados em Francisco et al., 2013).

\subsubsection{Via NER de Reparo de DNA e outros sistemas de Reparo na progressão de} Melanomas

O papel dos sistemas de reparo de DNA não tem sido apenas relacionado aos processos de carcinogênese. Embora o pensamento intuitivo remeta os sistemas de reparo aos passos iniciais do desenvolvimento de melanomas, tal pensamento tem sido discutido nos últimos anos devido a interessantes resultados apresentados por alguns estudos. Estudo publicado em 2008 (Kauffman et al., 2008) sugeriu novas funções do sistema de reparo na progressão e metástases de melanomas ao analisar a expressão gênica de melanomas primários que mais tarde tiveram a capacidade de formar metástases e de melanomas primários que não metastatizaram e compará-las. Resultados demonstraram alta expressão de genes de reparo e de manutenção da estabilidade genômica nos melanomas que tiveram capacidade de metastatizar. Tais resultados sugeriram que a alta expressão destes genes poderia de alguma maneira favorecer o crescimento tumoral e a capacidade invasiva de células tumorais, uma vez que ajudariam a manter o background genético favorável de certas células com tais 
capacidades citadas. Neste contexto, devido à alta taxa proliferativa e possibilidade de alterações decorrente dos mais diversos tipos de agressões genotóxicas, a estabilidade genética se torna crucial para a progressão do melanoma.

Estudos subsequentes também demonstraram a alta expressão de alguns genes de reparo de DNA em amostras de melanomas quando comparadas a amostras de pele normal e demais carcinomas de pele não melanoma (Jewell et al., 2010; Khao et al., 2011). Contudo, a maioria dos genes da via NER demonstrou expressão diminuída (Khao et al., 2011), fato que sugere que essa baixa expressão pode ter contribuído para os passos iniciais da transformação maligna dos melanócitos. Neste contexto de resultados, pode-se sugerir que os sistemas de reparo de DNA (mais especificamente a via NER) estão mais relacionados aos passos da iniciação do processo tumoral, onde muitas vezes se apresentam pouco funcionais ou demonstram baixa expressão de seus componentes proteícos, enquanto a alta expressão de genes de outras vias de reparo está mais relacionada aos processos de progressão, onde facilitam a manutenção de um genoma que favorece os processos de crescimento e metástase.

Da mesma maneira que a expressão de genes de reparo tem sido relacionada à progressão, a expressão desta classe de genes também apresenta correlação com resposta à quimioterapia em melanomas (Jewell et al., 2010).

\subsubsection{Via NER e resposta a quimioterápicos em Melanomas}

Existem duas características marcantes de melanomas. A primeira, o seu desenvolvimento como um resultado da exposição à radiação UV e, a segunda, a eficácia limitada da quimioterapia, em especial ao agente cisplatina (Bradbury \& Middleton, 2004). Cisplatina induz ligações intra e inter-fitas no DNA que causam 
lesões distorcivas à dupla-hélice, de maneira similiar as causadas por danos UV. Além de reparar fotoprodutos induzidos por UV, a via NER também parece estar envolvida na remoção de lesões causadas por cisplatina (Friedberg, 2001). Um estudo realizado por Bowden e colaboradores (Bowden et al., 2010) investigou o nível de expressão de genes da via NER após danos induzidos por cisplatina em melanomas e melanócitos. Os resultados mostraram uma expressão basal mais elevada de genes da via NER em melanomas. No entanto, quando comparada com a expressão em melanócitos, houve uma significativa falta de indução de genes como XPC, DDB1 e DDB2. Em contraste, a expressão de genes da sub-via TCR (CSA e CSB) foi baixa em ambos melanomas e melanócitos, sugerindo que o TCR não desempenha um papel na resposta à cisplatina. Os resultados deste estudo indicam que a falta de indução NER, especialmente GGR, pode desempenhar um papel na resistência de melanoma à cisplatina. Estudos posteriores identificaram que o componente ERCC1 poderia desempenhar um papel chave tanto no desenvolvimento de melanomas quanto sua resistência à cisplatina (Song et al., 2011; Li \& Melton, 2012).

Recente estudo, ao contrario dos dados apresentados por Bowden (Bowden et al., 2010), demonstrou que existe sim indução de XPC e DDB-2 após tratamento com agentes quimioterápicos que induzem lesões intra e inter-fitas no DNA, como cisplatina, afirmando que esta indução estaria relacionada a aquisição de resistência (Barckhausen et al., 2014). Por outro lado, também há estudos que sugerem que a resistência à cisplatina esteja mais relacionada à via TCR-NER, onde XPC não teria papel relevante nesta resistência (Enoiu et al., 2012). Embora não exista ainda um consenso sobre qual das sub-vias de NER esteja mais relacionada ao processo resistência à cisplatina, os dados em geral demonstram que existe relação desta via de reparo com a 
quimioresistência apresentada por diversos tumores, sendo melanoma um destes (Bowden et al., 2014). De qualquer maneira, mais estudos sobre o papel de NER na resistência e sensibilidade a cisplatina em melanomas são requeridos.

1.4 Modulações da função de XPC e desenvolvimento de melanomas: Possíveis relações?

Os diversos estudos que investigaram o papel dos sistemas de reparos de DNA e o padrão mutacional de lesões UV em melanomas, acima relatados, denotam uma importante perspectiva quanto ao papel do sistema de reparo NER e o desenvolvimento de melanomas: o papel de XPC neste contexto.

O papel de XPC para o desenvolvimento de tumores cutâneos, mais especificamente melanomas, pode ser afirmado em estudos que analisam o aparecimento destes tumores em indivíduos portadores de Xeroderma Pigmentosum, as quais as mutações acometem o gene $X P C$. Recente revisão sobre achados dermatológicos em pacientes XP-C, demonstrou o aparecimento de melanomas em tais indivíduos (Hadj-Rabia et al., 2013), o que evidencia o papel de XPC na supressão de lesões do tipo UV potencialmente carcinogênicas. Porém, não apenas mutações deletérias em XPC parecem estar envolvidas. O padrão mutacional exibido nos estudos de sequenciamento em larga escala mostrou maior frequência de mutações do tipo UV justamente em regiões não transcritas dos genomas analisados (Pleasance et al., 2010; Berger et al., 2012). São nestas regiões não transcritas que o GGR-NER, o qual XPC atua no processo de reconhecimento, tem sua maior atividade.

Diante destas informações, fica claro que a funcionalidade de XPC parece crucial nos processos de supressão/aquisição de mutações carcinogênicas no desenvolvimento de melanomas. Assim, se alterações que inativam por completo a 
atividade de XPC (mutações e silenciamentos gênicos por metilação, como exemplo) não ocorrerem nos passos iniciais da transformação maligna, outros processos que modulam a atividade de reconhecimento e reparo desencadeada por XPC podem atuar, contribuindo assim para menor atividade de reconhecimento e reparo.

Dentre as possíveis modulações de XPC, podemos citar sua interação com demais proteínas que agem como partners de sua atividade, seja o exemplo mais proximal, sua interação com o fator hHR23B (Roche et al., 2008), sua expressão dependente de importantes proteínas reguladoras como p53, além dos possíveis efeitos moduladores das variações genéticas existentes no gene.

\subsubsection{Modulação da atividade proteica de XPC: Funções da proteína Rad23}

Rad23 (proteína encontrada em leveduras, a qual é denominada de hHR23 em humanos e apresenta duas formas, hHR23A e hHR23B) é uma proteína bastante conhecida por seu papel como partner de XPC no reconhecimento de lesões. No entanto, alguns estudos mostram que tal proteína atua também na regulação da degradação de proteínas intracelulares (Dantuma et al., 2009). Embora o papel de $\operatorname{Rad} 23$ neste último processo seja pouco conhecido, é claro que $\operatorname{Rad} 23$ exerce um papel importante no NER. O conhecimento das características estruturais de $\operatorname{Rad} 23$ quanto à seus ortólogos humanos tem sido muito revelador em termos de compreender melhor as possíveis funções dessa proteína quanto aos mecanismos moleculares Rad23dependente. Estudos iniciais indicaram a participação de $\operatorname{Rad} 23$ na degradação proteassomal ubiquitina-dependente, onde sob condições in vitro $\operatorname{Rad} 23$ estaria envolvido na regulação negativa da formação de cadeias poli-ubiquitinadas, estabilizando assim substratos para o proteassoma (Ortolan et al., 2000). Com base 
nestes resultados, foi proposto que $\operatorname{Rad} 23$ é um regulador negativo da degradação proteassomal. Dois estudos subseqüentes abordaram esta primeira conclusão detalhadamente e mostram que $\operatorname{Rad} 23$ também poderia atuar no recrutamento de proteínas poli-ubiquitinadas para o proteassoma e facilitar a sua degradação (Verma et al., 2004). Embora limitações técnicas possam ser responsáveis pelas funções aparentemente opostas de Rad23, ora como inibidor ora como facilitador da degradação de proteínas, ainda sim existe a possibilidade de que as duas funções possam cooperar para garantir a eficiência e a seletiva degradação via proteassoma.

Rad23, ou mais precisamente hHR23A e hHR23B em humanos, é comumente descrito como partner funcional de XPC. Estudos mostram que XPC tem uma afinidade moderada para DNA em geral, mas o tempo de permanência do XPC é fortemente prolongado quando encontra uma lesão, explicando o acúmulo seletivo de XPC em DNA danificado por UV (Hoogstraten et al., 2008). XPC está sujeita a ubiquitinação induzida por UV por um complexo de ligases de ubiquitina (Gillette et al., 2006), entretanto esta poli-ubiquitinação de XPC pelo complexo UV-DDB não causa degradação da proteína, contudo esta modificação altera a capacidade de ligação de XPC ao DNA.

Curiosamente, XPC é rapidamente entregue para a degradação proteassomal em células de camundongos knock-outs para mHR23A e mHR23B (Ng et al. 2003; Okuda et al., 2004). O mesmo estudo mostra que mHR23A e B não são apenas muito semelhantes estruturalmente, mas também apresentam redundância funcional em NER, uma vez que células faltando ora mHR23A ora mHR23B ainda são NER proficiente, embora menos proficiente quanto mHR23B está ausente, uma vez que este é mais expresso e esteja mais relacionado a atividade de reparo junto a XPC ( $\mathrm{Ng}$ et al. 2003). 
No entanto, a supressão de mHR23B, mas não mHR23A, faz com que ocorram vários defeitos de desenvolvimento ( $\mathrm{Ng}$ et al. 2002), sugerindo que mHR23B exerça outras funções.

Recentemente, outra função têm sido atribuída a hHR23B no que diz respeito a sua participação na estabilidade de p53. Estudos utilizando siRNA contra hHR23B demonstraram que, o knock-down da proteína leva a acumulação de formas ubiquitinadas de p53, acelerando sua degradação (Brignone et al., 2004). Tal mecanismo mostrou estar relacionado a um complexo hHR23 e MDM-2, um repressor natural de p53. Conseqüentemente a esta maior degradação de p53, o mesmo grupo demonstrou em outro estudo, que a depleção de hHR23B atenuou a expressão de p21 and BAX, dois genes downstream da via de p53, após insulto genotóxico, culminando com supressão da apoptose (Kaur et al., 2006). Além disso, hHR23B se co-localizou com p53 no promotor de p21 após o agravo, sugerindo também sua participação na atividade transcricional de $\mathrm{p} 53$.

A função de hHR23B em tumores ainda é pouco explorada. Em câncer de pulmão, foi mostrado que hHR23B atua juntamente com p53, evitando sua degradação. Neste caso, a estabilidade de p53 permite com que a mesma atue na repressão de MMP1, inibindo assim o processo de metástase (Wu et al., 2010). Como XPC pode ser silenciado epigeneticamente em tumores pulmonares, sua perda de expressão desestabiliza hHR23B, culminando com degradação de p53 e aumento da expressão de MMP-1, contribuindo assim ao processo de metástase. Já em melanomas, embora nenhum estudo funcional tenha sido feito, análise de expressão gênica comparando linhagens celulares originadas de melanomas de crescimento radial com linhagens celulares originadas de melanomas de crescimento vertical demonstrou perda de 
expressão de hHR23B nas linhagens de crescimento vertical, dado que chama a atenção para a possível participação de hHR23B na biologia de melanomas (Sousa \& Espreafico, 2008).

Assim, como o papel de mutações do tipo UV no desenvolvimento de melanomas tem ganhado novos dados que suportam sua importância, além de indicarem a participação de mecanismos XPC dependentes na aquisição destas mutações, o estudo de fatores que possam modular a atividade de XPC, podem contribuir para o conhecimento do desenvolvimento de melanomas.

\subsubsection{Modulação da expressão de XPC: papel de p53}

A via de NER apresenta importante interação com o gene supressor tumoral p53, particularmente no que consiste a ativação da via de GGR-NER . P53 é um factor de transcrição que desempenha um papel importante no controle do ciclo celular, apoptose e resposta a danos no DNA, com um papel crítico na proteção contra a carcinogênese (Balint \& Vousden, 2011). Uma maneira na qual p53 pode regular a resposta ao dano no DNA é através do seu alvo downstream GADD45, que desempenha papel no reparo do DNA como pode ser constatato em células deficientes neste gene, as quais apresentaram reduzida eficienência no reparo de lesões induzidas por UV (Smith et al., 2000). No entanto, estudos recentes sugerem que p53 pode afetar diretamente a expressão de genes XPC e DDB2 (XPE). Tem sido demonstrado que as células com mutações em p53 têm deficiências na remoção de ambas as lesões do tipo CPDs e 6-4 PP, no entanto este reparo deficiente parece estar limitado a regiões não-transcritas, sugerindo que se trata da via GGR-NER que requer p53 funcional e que a remoção dos mesmos danos em regiões transcritas mediadas por TCR-NER é ainda proficiente (Ford \& Hanawalt, 
1997; Mathonnet et al., 2003). Estudos mostram que a expressão de XPC é induzida por p53 em células do tipo selvagem, no entanto, tal expressão não é observada em células deficientes em p53. Uma análise mais detalhada da região promotora de XPC mostrou um possível elemento de resposta a p53, o que sugere que p53 pode controlar diretamente a expressão do gene XPC (Adimoolam \& Ford, 2002). Outros estudos têm demonstrado que a expressão de DDB2 (XPE) também é dependente de p53. Observouse que os níveis de mRNA de DDB2 eram dependentes da expressão de p53 basal e que apresentaram aumento após danos no DNA de um modo dependente da p53 (Hwang et al., 1999). Um estudo subsequente de análise do gene DDB2 mostrou que este também contém em sua região promotora uma região na qual p53 pode controlar sua transcrição (Tan \& Chu, 2002). Juntos, estes resultados mostram que p53 controla diretamente o reparo de danos no DNA após UV por meio da expressão de genes da via GGR-NER XPC e DDB2 (XPE).

Dada esta relação direta entre p53 e genes da via GGR-NER, seria interessante especular que mutações em p53 poderiam facilitar a aquisição de mutações por exposição à UV, uma vez que a via GGR-NER estaria comprometida por menor expressão de XPC e DDB-2. No entanto, a relação entre p53 e desenvolvimento de melanomas continua uma interessante questão em construção. Isto porque a proporção de amostras de melanomas com mutações em p53 é extretamente baixa, em torno de 7\% (variando entre 0 a 24\%)(de Snoo \& Hayward, 2005). No entanto, estudos têm sugerido que embora selvagem, p53 demonstra certa inatividade transcricional em melanomas (Houben et al., 2011). Dados obtidos a partir de linhagens de melanoma têm corroborados com esta premissa de que diferentes alvos transcricionais de p53 se encontram com baixa expressão, principalmente quando comparados com sua expressão 
em amostras névicas, sugerindo assim um p53 disfuncional nestes melanomas (Yu et al., 2009). Estes relatos tem demonstrado que outros mecanismos podem estar envolvidos na inativação da atividade de p53 em melanomas, o que pode influenciar seja no desenvolvimento desta neoplasia, na sua progressão e também na resposta a agentes quimioterápicos.

\subsubsection{Modulação de XPC: possível papel de polimorfismos genéticos?}

Outra fonte possível de modulação da função gênica pode ser atribuída a variações genéticas existentes nos genes. O sequenciamento do genoma humano permitiu a identificação de variações genéticas em importantes genes, os quais através de estudos epidemiológicos do tipo caso-controle sugerem a participação destas variações como genes de baixa penetrância para o desenvolvimento de doenças.

Para compreender a base mecanistica através da qual um polimorfismo pode estar associado com um fenótipo em particular é necessário saber se que o polimorfismo é funcional (ou seja, se altera a função de um gene ou conjunto de genes). Na maioria dos casos, a função de um polimorfismo não está definida e deve ser imaginada ou extrapolada como um efeito sobre o gene que contém este polimorfismo. Em casos raros, o polimorfismo pode ser uma variação não sinônima em regiões de codificação de aminoácidos que altera a estrutura da proteína. Polimorfismos mais comuns são potenciais polimorfismos regulatórios localizados em regiões não codificadoras, incluindo regiões promotoras downstream/upstream e também em regiões intronicas, que podem afetar a transcrição (Chorley et al., 2008). Em introns e regiões UTR, polimorfismos podem alterar processos de transcrição, splicing e tradução (Sadee et al., 2011). 
Polimorfismos individuais podem ter impacto funcional mínimo, mas podem estar em desequilíbrio de ligação com um conjunto de polimorfismos que formam um haplótipo associado a um resultado funcional na expressão ou função do gene. Considerando que um polimorfismo pode ter um efeito demonstrado na função de um gene, existem diferentes maneiras de demonstrar a função de uma variante genética. Estes vão desde estudos in vitro até estudos que buscam determinar o impacto funcional de um determinado polimorfismo sobre a expressão gênica em humanos como a mais clara indicação de um "polimorfismo funcional." Assim, para fins de geração de discussão sobre esta questão, um potencial sistema para classificar a função de uma variante ou polimorfismo de sequência pode ser apresentado (Albert, 2011):

Classe 0: Função não determinado. Ou (A), a função é conhecida, ou (B) a função teórica é pode ser prevista, mas não foi demonstrada experimentalmente;

Classe 1: Funcional in vitro. O efeito funcional do polimorfismo de um elemento de DNA-alvo ou mecanismo de regulação tem sido demonstrado através de ensaios in vitro (por exemplo, shifting in gel, ensaios repórter, ensaios de ligação e interação a alvos); no entanto, a função do polimorfismo na expressão do gene endógeno ou in vivo é desconhecida;

Classe 2: Funcional in vivo. Em adição aos requisitos da classe 1, (A) Efeito da função do polimorfismo no gene endógeno foi testado no modelo de sistemas celulares (por exemplo, linhagens de células humanas transformadas, linfócitos humanos, culturas de células primárias) usando métodos tais como expressão alélica e imunoprecipitação da cromatina, e (B) em função in vitro correlaciona-se com uma mudança funcional em tecido humano; 
Classe 3: Fenocópia Funcional. Em adição aos requisitos da classe 1, função (A) tem sido demonstrada in vivo utilizando modelos de organismos, tais como camundongos knock-out, e a função (B) está correlacionada com uma mudança funcional em tecidos humanos.

Nota-se que, dentro de cada classe, o grau de perturbação funcional pode variar. Assim, a classificação de classe não indica a magnitude do impacto funcional do polimorfismo. Em vez disso, ele só indica o grau em que o impacto tem sido investigado. Além disso, a classe de um polimorfismo não implica a sua importância em uma dada população: um polimorfismo pode ter um grande impacto sobre a função in vivo, mas é muito raro e não é útil como um marcador na população em geral.

Diversos genes de reparo apresentam variantes polimórficas, incluindo XPC. Dos diferentes polimorfismos existentes, os mais frequentes e estudados são: uma inserção de 83 pares de bases de repetições AT no intron 9 (polimorfismo conhecido como PAT+), uma substituição de citosina para adenina no sitio de splicing do intron 11 (polimorfismo conhecido como IV11-6C/A) e a troca de uma Lisina por Glutamina no códon 939 da proteína (K939Q)(Khan et al., 2000; Khan et al., 2002). Além disso, os três polimorfismos apresentam forte desequilíbrio de ligação, sendo assim, herdados juntos no formato de um haplótipo.

Diversos estudos têm analisado os possíveis impactos destes polimorfismos de $X P C$ na susceptibilidade a diversos tipos de câncer, de onde estudos de meta-análise a partir de dados epidemiológicos casos-controle têm sugerido a participação destas variantes em alguns tipos específicos de tumores, como por exemplo pulmão, bexiga e cabeça e pescoço (Francisco et al., 2008). Quanto ao envolvimento destes polimorfismos com melanoma, diversos estudos foram feitos, com resultados diferentes. 
Os primeiros estudos conduzidos em populações européias (Blankenburg et al., 2005; Millikan et al., 2006; Povey et al., 2007) e norte-americanas (Li et al., 2006) não demonstraram participação dos polimorfismos de XPC na susceptibilidade a melanoma. No entanto, estudos posteriores de regiões com maiores índices de UV demonstraram que polimorfismos em XPC podem contribuir para o aumento do risco (Gonçalves et al., 2011; Oliveira et al., 2013; Torres et al., 2013). Em especial, no estudo de Gonçalves e colaboradores (2011), estudo este conduzido pelo grupo, os polimorfismos de $X P C$ se mostraram associados com demais fatores de risco no desenvolvimento de melanomas, demonstrando assim uma relação importante entre a existência de variantes genéticas de XPC e demais fatores de risco, como por exemplo, o padrão de exposição solar.

Já com relação a atividade funcional destes polimorfismos, alguns estudos procuraram investigar seus possíveis efeitos na atividade de XPC e consequentemente de reparo. Alguns estudos sugeriram menor capacidade de reparo conferida a estes polimorfismos, principalmente em relação aos polimorfismos PAT+ e K939Q, no entanto tais estudos são baseados em linfócitos de pacientes, método que pode estar sujeito a outras variações genéticas que não foram analisadas (Qiao et al., 2002). O outro polimorfismo de XPC estudado funcionalmente é a mudança da base citosina por adenina no nucleotídeo - 5 do sitio aceptor de splice do íntron 11. Com esta alteração, a chance de um processamento do RNA perder o exon 12 é aumentada, pois a afinidade de ligação e reconhecimento do spliceossomo é diminuída. Esta hipótese foi verificada e os resultados indicaram que indivíduos com genótipo AA tinham um aumento significativo de perda do exon 12 em comparação aos indivíduos $\mathrm{CC}$, enquanto os heterozigotos (CA) também tinham um aumento significativo, mesmo sendo este 
intermediário, onde esta maior perda do exon 12 do genótipo AA correlacionava-se com menor atividade de reparo (Khan et al., 2002). Já a análise funcional desta deleção do exon 12 resultou em perda da função de um cDNA de XPC em corrigir a atividade de reparo de células XP-C. Além disso, os resultados demonstraram um efeito dominante negativo da função de reparo em células normais (Khan et al., 2002). A perda deste exon leva consequentemente a perda do sítio de interação de XPC com hHR23B (Li et al., 1997).

No entanto, uma maior análise do impacto destes polimorfismos, seja na estabilidade do mRNA, uma vez que dois dos polimorfismos estão localizados em regiões intrônicas (sendo uma delas no sitio de splicing), seja na atividade da proteína mediante a troca de lisina por glutamina no códon 939 ainda não foram devidamente exploradas, principalmente para neoplasias tais como o melanoma. Neste caso, o estudo das possíveis modulações que estes polimorfismos de XPC possam causar na função da proteína e consequentemente no processo de reparo de DNA, pode contribuir para o entendimento do papel de $X P C$ no desenvolvimento de melanoma.

Desta maneira, agora com a descrição de variantes polimórficas que podem interferir com atividade do gene/proteína, há um cenário de investigação para o possível estudo dos fatores que influenciam na atividade de XPC. Dada a importância que a atividade de XPC e de reparo de DNA em si tem mostrado no desenvolvimento de melanomas, o estudo das atividades que possam modular essas atividades, contribuindo para a aquisição de mutações carcinogênicas, tem grande importância no entendimento da biologia do desenvolvimento de melanomas, e consequentemente é o objetivo desta tese. 


\section{OBJETIVOS}

\subsection{Objetivo Geral}

Avaliar o papel de possíveis agentes modificadores da função da via GGR-NER (Global Genomic Repair - Nucleotide Excision Repair) na resposta a exposição à UVB, na atividade de XPC e na resposta ao tratamento com o quimioterápico cisplatina.

\subsection{Objetivos específicos}

2.2.1 Verificar o papel funcional de p53 em linhagens de melanoma expostas a UVB quanto a $(o)$ :

- sensibilidade à radiação UVB;

- expressão de proteínas da via NER e atividade de reparo de lesões UVB;

- padrão de morte e expressão de proteínas relacionadas a morte por exposição à UVB;

- papel da neutralização de espécies reativas de oxigênio após exposição à UVB;

- papel de espécies reativas de oxigênio na sensibilidade a UVB.

2.2.2 Verificar o possível papel de moduladores da função de XPC na biologia de melanomas, incluindo para isto:

- avaliar a análise da expressão de hHR23B em amostras de lesões melanociticas, incluindo nevus, melanomas primários e metástases;

- avaliar a expressão de hHR23B em linhagens de melanoma e possíveis consequencias da sua expressão diferenciada na sensibilidade e atividade de reparo de DNA após lesões por UVB;

- avaliar o papel de hHR23B na estabilidade e acumulação de XPC; 
- avaliar o papel de hHR23B e XPC na sensibilidade a quimioterápicos;

- avaliar se a presença de variantes polimórficas de XPC influencia na expressão relativa em cada um dos alelos existentes.

2.2.3 Verificar o papel funcional de p53 em linhagens de melanoma expostas a cisplatina quanto a $(o)$ :

- sensibilidade à cisplatina;

- expressão de proteínas da via NER e atividade de reparo a lesões por cisplatina;

- padrão de morte e expressão de proteínas relacionadas à morte por exposição à cisplatina.

Além destes tópicos, esta seção também apresenta como objetivos:

- verificar o papel de XPC na resposta à cisplatina;

- verificar o papel de moléculas estimuladoras da função de p53, como por exemplo, Nutlin-3, na resposta à cisplatina. 


\section{MATERIAS E MÉTODOS}

\subsection{Cultivo de Células}

As linhagens de melanoma utilizadas foram: LB373-mel (Zhu et al., 2003), Mel85 (Senff-Ribeiro et al., 2004), Skmel-28 (Fogh et al., 1977) Skmel-37 (Carey et al., 1976), Mz2-Mel (Traversari et al., 1992), SBCL2 (Sturm et al., 2002), NGM (Banco de Células UFRJ), WM905 (Instituto Wistar - Filadélfia, EUA), MeWo (Carey et al., 1976), Melan-a (Bennet et al., 1987), TM1 (Oba-Shinjo et al., 2006), B16F10 (Fidler, 1975) e as demais linhagens (Skmel-05, Skmel-147, UACC-62, Skmel-29 e Skmel-103). As linhagens de melanoma foram cultivadas em meio de cultura específico suplementado com soro fetal bovino (SFB) $\left(\right.$ Cultilab $\left.^{\circledR}\right)$. As linhagens LB373, Mel85, Skmel-28, MZ2-MEL, SBCL2, WM905, MeWo, Melan-a, TM1 e B16F10 foram cultivadas com meio RPMI 1640 da Sigma-Aldrich ${ }^{\circledR}$ pH 7.2, suplementado com 25 mM de HEPES (ácido N-2-hidroxietilpiperazina-N-2-etanosulfonico) e Bicarbonato de Sódio 24 mM. Já Skmel-37 foi cultivada com meio MEM (Minimum Essential Medium) da Sigma-Aldrich ${ }^{\circledR}$ pH 7.2 também suplementado com 25 mM de HEPES (ácido N-2-hidroxietilpiperazina-N-2-etanosulfonico) e Bicarbonato de Sódio $24 \mathrm{mM}$. As linhagens Skmel-05, Skmel-147, UACC-62, Skmel-29 e Skmel-103 foram cultivadas em meio DMEM pH 7.2, suplementado com 25 mM de HEPES (ácido N-2hidroxietilpiperazina-N-2-etanosulfonico) e Bicarbonato de Sódio $24 \mathrm{mM}$. Todas as linhagens foram cultivadas com 10\% de SFB, com exceção a Melan-a e TM1, que foram cultivadas com SFB a 5\%. A metodologia de cultivo de Melan-a também teve de ser suplementada com $0.2 \mu \mathrm{M}$ de PMA (Phorbol-12-myristate 13-acetate - Sigma Aldrich). As culturas celulares foram mantidas em estufa de $5 \%$ de $\mathrm{CO}_{2}$. O descolamento das células para posterior contagem e subcultivo foi feito por curta exposição à PBS-EDTA (Phosphate buffered Saline - Ethylenediamine tetraacetic acid) 
e tripsina. As células foram contadas através da utilização de câmera de Neubauer, e o plaqueamento das células se deu de acordo com o experimento a ser conduzido.

\subsection{Ensaios de Morte Celular}

Para se avaliar ensaios de sensibilidade a UVB, cerca de $3.5 \times 10^{4}$ células foram plaqueadas em placas de 12 poços e após $24 \mathrm{~h}$ de plaqueamento, as células foram irradiadas a diferentes doses de UVB. Para tal, a quantidade de energia emitida pela lâmpada UVB foi mensurada utilizando-se um dosímetro (Instrutherm). A medida fornecida pelo instrumento é dada em $\mu \mathrm{W} / \mathrm{cm}^{2}$, onde o valor obtido foi utilizado para transformação em $\mathrm{J} / \mathrm{m}^{2}$ de acordo com os valores acima estipulados. Dessa transformação obteve-se o valor referente ao tempo de exposição à UVB.

Para exposição, as células na placa tiveram o meio retirado, sendo substituído por solução HBSS 1x (Hank's Buffered Salt Solution). Após a irradiação, o HBSS foi retirado, sendo substituído por meio RPMI ou MEM (para Skmel-37) mais 10\% SFB. Após 24 e/ou 48h de exposição à UVB, o sobrenadante foi retirado e as células aderidas foram lavadas e tripsinisadas, com posterior fixação das células em etanol $70 \%$, e mantidas congeladas até o momento da análise por citometria de fluxo (citômetro FACScalibur Becton Dickson).

Já para a análise quanto a sensibilidade a exposição à cisplatina, cerca de $3.5 \times 10^{4}$ células foram plaqueadas em placas de 12 poços e após $24 \mathrm{~h}$ de plaqueamento, as células foram tratadas com diferentes doses de cisplatina. As células foram deixadas expostas a cisplatina por $24 \mathrm{~h}$, sendo após este tempo retirou-se o meio de cultura, lavando-se as células com PBS e recolocado meio de cultura suplementado com $10 \%$ de SFB. Após mais $24 \mathrm{~h}$ com meio de cultura livre de cisplatina, o 
sobrenadante foi retirado e as células aderidas foram lavadas e tripsinisadas, com posterior fixação das células em etanol $70 \%$, e mantidas congeladas até o momento da análise por citometria de fluxo.

O processo de morte foi avaliado pela incorporação de iodeto de propídio (PI), que se incorpora estequiometricamente ao DNA, permitindo uma quantificação relativa do conteúdo de DNA de uma população de células. Células apresentando quantidade de DNA inferior a $2 \mathrm{n}$ (hipodiplóides $=\mathrm{H} 0$ ) foram consideradas em morte celular. Para tal, as células foram centrifugas por 5 min a $3000 \mathrm{rpm}$, após descartado o etanol vertendo os tubos, o pellet foi lavado com PBS, centrifugando-se novamente a $300 \mathrm{~g}$ por $5 \mathrm{~min}$. O sobrenadante foi retirado e o pellet ressuspendido em $200 \mu \mathrm{lde}$ solução PI (20 ml de PBS, $20 \mu \mathrm{l}$ e Triton $0.1 \%, 200 \mu \mathrm{g} / \mathrm{ml}$ RNase, $20 \mu \mathrm{g} / \mathrm{ml}$ PI) transferindo as amostras para tubos FACS. Após 30 min de incubação, foi feita a captação das células marcadas pelo citômetro. A análise da citometria de fluxo foi realizada usando-se o programa Cell Quest Pro da Becton \& Dickson. A porcentagem das células nas diferentes fases do ciclo celular foi quantificada e os dados foram expressos em gráficos de histogramas. Como ilustrado na figura 3, a porcentagem de células encontradas no primeiro segmento (M1) foi considerada representativa das células em morte celular, pois este segmento contém células com conteúdo de DNA abaixo de 2n (hipodiplóides). O segundo segmento (M2) foi definido pelo primeiro pico de eventos, onde havia células com conteúdo de DNA compatível com a fase G0/G1 do ciclo celular. O terceiro segmento (M3) apresenta células que caracterizam as fases $\mathrm{S} / \mathrm{G} 2 / \mathrm{M}$ do ciclo celular. O quarto segmento (M4) representa agregados celulares, estes desconsiderados na análise. 


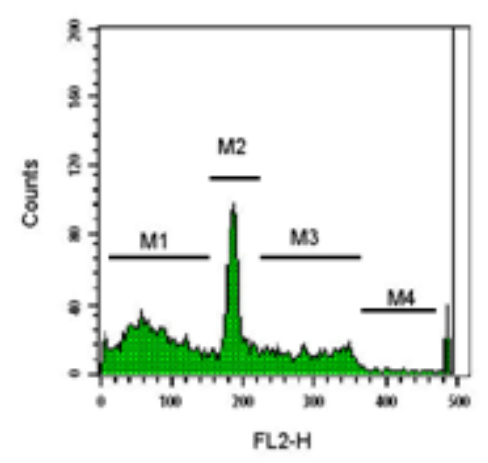

Figura 3. Esquema representativo da análise de ciclo celular através de um histograma. Adaptado de www.boku.ac.at/iam/poster/?C=M;O=D.

\subsection{Morte Celular e Deprivação de Soro}

Para testar se a passagem pela fase $S$ do ciclo celular interfere com o padrão de morte celular, utilizaram-se duas diferentes concentrações de soro para inibir/estimular o ciclo celular e averiguar sua influência na morte celular por cisplatina. Para tal, a mesma metodologia para averiguar a morte celular por cisplatina descrita acima foi utilizada. No entanto, no grupo com deprivação de soro foi utilizado $2 \%$ de SFB e no grupo de estimulação, $20 \%$ de SFB. Após $24 \mathrm{~h}$ de tratamento com $12.5 \mu \mathrm{M}$ de cisplatina, o meio foi trocado por meio de cultura novo, mantendo-se as mesmas concentrações de soro utilizadas. Após mais 24h, as células foram extraídas para análise de morte celular e fase de ciclo por análise em FACS, conforme descrito acima.

\subsection{Ensaios de Sobrevivência por formação de colônias}

Para ensaios de sobrevivência, cerca de 1000 células foram plaqueadas em placas de $60 \mathrm{~mm}$ e após $24 \mathrm{~h}$ de plaqueamento as células foram expostas a doses diferentes de ultravioleta e deixadas 10-15 dias para formação de colônias. A exposição à UVB se deu da mesma maneira que descrito para os ensaios de morte celular, no entanto, optou-se por avaliar a capacidade de sobrevivência das células após as doses de 
30, 60 e $120 \mathrm{~J} / \mathrm{m}^{2}$. Após esse período as colônias foram fixadas com solução $1 \%$ de paraformaldeído por 15 min e corados com $0.1 \%$ de cristal de violeta. O número de colônias após o tratamento indica a capacidade de sobrevivência e multiplicação das células após determinado tratamento. O número de colônias foi quantificado a olho nu em cada condição.

Para o ensaio de formação de colônias utilizando cisplatina, a mesma metodologia foi aplicada. Neste caso em específico, as células isoladas foram tratadas com cisplatina às concentrações de $0.5,1$ e $5 \mu \mathrm{M}$ de cisplatina por $24 \mathrm{~h}$. Após este período, o meio de cultura foi retirado e novo meio isento de cisplatina foi colocado.

\subsection{Extração de Proteínas e Dosagem proteica}

Para avaliação da expressão protéica das linhagens celulares após os tratamento e condições analisadas, as células foram tripsinizadas, centrifugadas e ressuspendidas em tampão hipotônico RIPA (Tris-HCl 10 mM, pH 7.4; EDTA 5 mM; NaCl 150 mM; Triton X-100 1\%; deoxicolato de sódio 1\%; SDS 0.1\%) no qual inibidores de protease foram adicionados $(0.1 \mathrm{mM}$ PMSF, $5 \mu \mathrm{g} / \mathrm{ml}$ de aprotinina e $0.1 \mathrm{M}$ de Ortovanadato de Sódio). As células foram homogeneizadas e colocadas a $4^{\circ} \mathrm{C}$ por 15 minutos. $\mathrm{O}$ homogenato foi centrifugado a $4^{\circ} \mathrm{C}$ por 15 minutos a $13000 \mathrm{rpm}$.

Foi feito a dosagem proteíca de acordo com uma modificação do método descrito por Lowry (Lowry et al., 1951). A dosagem de proteínas foi realizada utilizando-se o kit Reagente BCA para Ensaio de Proteínas (Lowry modificado), da BioAgency ${ }^{\circledR}$, de acordo com o manual do fabricante. Foi utilizado solução de BSA de concentração determinada como padrão para criação de curva padrão de concentração. A solução de reagentes A e B do kit BCA foi preparada na proporção de 50:1 (A:B). As 
amostras a serem dosadas foram postas em triplicatas $(10 \mu \mathrm{l}$ cada) em placas de 96 poços juntamente com $200 \mu 1$ da solução de detecção. A placa foi deixada a $37^{\circ} \mathrm{C}$ por 30 min, protegida da luz para a reação colorimétrica acontecer. Para leitura das amostras, foi utilizado um leitor de microplacas (BioRad microplate Reader) utilizando-se filtros de $592 \mathrm{~nm}$. A concentração de proteínas em $\mu \mathrm{g} / \mu \mathrm{l}$ foi determinado através de comparação à curva obtida através do BSA padrão.

\subsection{Gel de Poliacrilamida e Western Blotting}

A análise dos extratos protéicos foi realizada através da separação de acordo com sua massa molecular aparente (SDS-PAGE). As amostras de extratos protéicos foram incubadas em tampão redutor (120 mM Tris pH 6.8, 4\% SDS, 200 mM DTT, $0.01 \%$ bromofenol blue e $20 \%$ glicerol) e aquecidas a $100^{\circ} \mathrm{C}$ em banho seco por 5 minutos, sendo posteriormente aplicadas em gel de poliacrilamida contendo $1.5 \mathrm{M}$ de

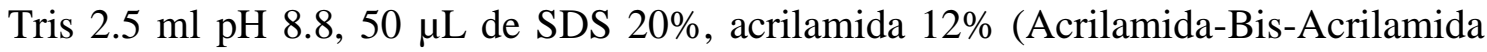
29:1-30\%), $200 \mu 1$ de Persulfato de Amônio (APS) 20\% , $3 \mu 1$ de TEMED (N,N,N tetra metilenodiamina) e $\mathrm{H}_{2} \mathrm{O}$ MilliQ q.s.p. $10 \mathrm{ml}$; e o gel de empilhamento 4\%, $1.25 \mathrm{ml}$ Tris $1 \mathrm{M} \mathrm{pH} \mathrm{6.8,} 50 \mu \mathrm{l}$ de SDS 20\%, $1.33 \mathrm{ml}$ acrilamida 30\%, $200 \mu \mathrm{l}$ de APS $20 \%$ APS, $3 \mu \mathrm{l}$ TEMED e $\mathrm{H}_{2} \mathrm{O}$ MilliQ q.s.p. $10 \mathrm{ml}$. Em seguida, os extratos protéicos separados foram transferidos para a membrana PVDF (Hydrophobic polyviniylidene difluoride, Amersham) para a realização do blotting, sendo feita em tampão Tris $25 \mathrm{mM}$, Metanol $20 \% \mathrm{H}_{2} \mathrm{O}$ MilliQ q.s.p. $1 \mathrm{~L}$ por uma hora a $100 \mathrm{~V}$ e a $4^{\circ} \mathrm{C}$.

A membrana teve seus sítios inespecíficos bloqueados com leite seco desnatado 5\% em PBS-Tween 0.2\% e incubada com os anticorpos: anti-hHR23B (Santa Cruz), anti hHR23A (Santa Cruz), anti-XPC (Santa Cruz), anti-DDB-2 (Santa Cruz), anti-p53 
(Santa Cruz), anti-Histona H3 (Abcam) e anti- $\beta$-actina (Sigma-Aldrich), $\gamma$-H2AX (Millipore), ERCC1 (Santa Cruz), p21 (Santa Cruz), ERK e phospho ERK (Calbiochem), nucleophosmin (NPM)(Neomarkers), Bcl-2 (Santa Cruz), PUMA (Santa Cruz), XPV (Santa Cruz), BAD (Santa Cruz), Beclin-1 (Santa Cruz) LC-3 (Santa Cruz). Com exceção de anticorpo anti- $\beta$-actina (incubação por cerca de $1 \mathrm{~h}$ temperatura ambiente), os demais anticorpos foram incubados por período overnight $4^{\circ} \mathrm{C}$. Utilizaram-se anticorpos secundários conjugados a peroxidase para revelação através do princípio de quimioluminescência. Para tal uma solução caseira para quimioluminescência foi utilizada, sendo esta composta de: Tris $100 \mathrm{mM} \mathrm{pH} \mathrm{8.8,}$ luminol $2.5 \mathrm{mM}$, ácido p-cumárico $2.5 \mathrm{mM}$ e $0.01 \%$ peróxido de hidrogênio $30 \%$ e $\mathrm{H}_{2} \mathrm{O}$ MilliQ q.s.p. $1 \mathrm{ml}$. As revelações foram realizadas utilizando-se o equipamento Image Quant (LifeScience).

\subsection{Ensaios de Recuperação de RNA}

Lesões causadas por exposições à ultravioleta também causam parada na maquinaria de transcrição, mais precisamente causando a parada da RNA polimerase II (Costa et al., 2003). Esta parada leva a ativação do reparo acoplado à transcrição (Figura 2). Deste modo a avaliação da recuperação de RNA é uma medida indireta da atividade deste tipo de reparo. Para tal, 1 x $10^{5}$ células foram plaqueadas em placas de Petri de $35 \mathrm{~mm}$, e após $24 \mathrm{~h}$ de plaqueamento as placas foram irradiadas com UVC em doses de 15 e $30 \mathrm{~J} / \mathrm{m}^{2}$. As análises da quantidade de RNA foram mensuradas nos tempos de 2, 6 e 24h após irradiação. Uma hora antes do tempo previsto, as células foram incubadas em 4,0 $\mu \mathrm{Ci} / \mathrm{ml}$ de uridina $\mathrm{H}^{3}$ (Amersham Pharmacia Biotech, USA). Após esse tempo, as células foram lavadas com PBS e tripsinizadas e posteriormente 
separadas em duas alíquotas para cada replicata. Em uma das alíquotas, as células foram lisadas em solução de lise ( $\mathrm{NaCl} 300$ nM; Tris-HCl pH 8.020 mM; EDTA 2 mM; SDS $1 \%$ e proteinase $\mathrm{K} 200 \mu \mathrm{g} / \mathrm{ml}$ ) e aplicadas em papel Whatman 17 em triplicatas. O papel foi lavado com TCA $15 \%$ e etanol absoluto por $2 \mathrm{x}$, para eliminação de material radioativo não incorporado. Após $24 \mathrm{~h}$ de secagem, o papel foi colocado em tubos para medida da radioatividade em cintilação liquida (Beckman LS 7000). A outra alíquota do lisado de células teve a absorbância medida $(260 \mathrm{~nm})$ para quantificação total do RNA (Nano Drop). A medida da quantidade de RNA serve como normalização dos dados. A razão entre as medidas de radioatividade e absorbância reflete o valor de síntese de RNA. Para tal experimento, linhagem de fibroblastos de pacientes CSB (Cokayne Syndrome B)(mutadas para o respectivo gene) foram usadas como controle, uma vez que tais pacientes apresentam sistema de reparo de DNA ineficiente na recuperação da transcrição após lesões UV. O experimento foi conduzido no laboratório do Prof Carlos Menck (ICB-USP). A linhagem CSB também foi proveniente do mesmo grupo. Fibroblastos provenientes de pacientes CSB foram cultivados em meio DMEM suplementado com $10 \%$ de SFB.

\subsection{Ensaios de Reparo de DNA lesionados por UVB}

A luz ultravioleta causa danos específicos de DNA que podem ser detectados através de anticorpos específicos contra estes tipos de lesões. Para verificar a eficiência de reparo das células, 1 × $10^{5}$ células foram plaqueadas em placas de Petri de $35 \mathrm{~mm}$, e após $24 \mathrm{~h}$ de plaqueamento as placas foram irradiadas a $120 \mathrm{~J} / \mathrm{m}^{2}$ de UVB. Para tal, a quantidade de energia emitida pela lâmpada UVB foi mensurada utilizando-se dosímetro de UVA/UVB modelos MRU-201 (Instrutherm). A medida fornecida pelo 
instrumento é dada em $\mu \mathrm{W} / \mathrm{cm}^{2}$, onde o valor obtido foi utilizado para transformação em $\mathrm{J} / \mathrm{m}^{2}$ de acordo com os valores acima estipulados. Dessa transformação obteve-se o valor referente ao tempo de exposição à UVB. Para exposição, as células na placa tiveram o meio retirado, sendo substituído por solução HBSS 1x (Hank's Buffered Salt Solution). Após a irradiação, o HBSS foi retirado, sendo substituído por meio RPMI ou MEM (para Skmel-37) acrescido de 10\% SFB.

O DNA das linhagens foi extraído após 0,6 e 24h da exposição, além de uma amostra de DNA não irradiado. Para extração do DNA foi usada solução de lise contendo $2 \%$ SDS e $25 \mathrm{nM}$ EDTA pH 8.0, onde após $24 \mathrm{~h}$ a temperatura ambiente foi adicionado solução de $7.5 \mathrm{M}$ acetato de amônia para denaturação de proteínas. O lisado foi centrifugado a $3200 \mathrm{rpm} 15$ min para precipitação de proteínas. O sobrenadante foi separado, sendo adicionado isopropanol, deixado para precipitação por $15 \mathrm{~min}$ a temperatura ambiente e centrifugado novamente a $10 \mathrm{~min}$ a $13000 \mathrm{rpm}$. O pellet resultante foi lavado com etanol 70\%, sendo novamente centrifugado a 10 min a 13000 rpm. Em seguida o sobrenadante foi removido, e o DNA dissolvido em água ultra-pura.

O DNA extraído foi quantificado em espectofotometria a 260/280 nm. Para o blotting, de 100 - 300 ng de DNA foram diluídos em $200 \mu$ de TE e aquecido a $95^{\circ} \mathrm{C}$ por 5 min para denaturação, sendo em seguida colocado em gelo por aproximadamente 5 min. Após período de incubação, as amostras de DNA diluídas em tampão TE (100 $\mathrm{mM}$ Tris- $\mathrm{HCl}$ e $10 \mathrm{mM}$ EDTA, $\mathrm{pH}=8.0$ ) foram aplicadas no aparato de dot-blot (Biodot SF BioRad), previamente lavado para os slots com TE. O aparato continha membrana de Nylon Hybond-N (Amersham) também pré-lavada com TE pH 8,0. Uma vez passadas pelo processo de blotting, a membrana contendo as amostras de DNA passaram por processo de "cross-link" através de secagem a $80^{\circ} \mathrm{C}$ por um hora, e em 
seguida a membrana foi bloqueada com 5\% leite seco diluído em TBS-Tween (50 mM Tris pH 7.5 e $150 \mathrm{mM} \mathrm{NaCl}$ ) na concentração de $0.2 \%$ por 1 h. Após bloqueio, foi adicionado anticorpo especifico para lesões tipo UV, seja para lesões do tipo CPD (Dímeros de Ciclobutano) ou lesões do tipo 6-4PP (fotoprodutos 6-4)(CosmosBio) e incubado over night a $4^{\circ} \mathrm{C}$. Posteriormente, a membrana foi incubada com o anticorpo secundário especifico peroxidase por uma hora. A revelação da membrana foi feita da mesma maneira descrita acima para Western blotting. Por fim, foi feito a densitometria das bandas através do programa Image $J$, para análise quantitativa da taxa de reparo no DNA e posterior montagem de gráfico.

Para controle da quantidade de DNA aplicado no blotting, a mesma quantidade em volume e concentração aplicada para o blotting foi colocada em tubos eppendorf, sendo adicionado depois $10 \mu \mathrm{l}$ de solução contendo SYBR Green Gold (Invitrogen) diluído a 10 mil vezes e deixados a reagir por 5 min a temperatura ambiente. Após este tempo, foi adicionado $200 \mu \mathrm{l}$ de TE e o volume total aplicado no aparato de dot blot contendo membrana Hybond-N, da mesma maneira descrita acima. A membrana foi então retirada e fotografada sob luz UV e a imagem captada com auxílio de software existente no aparelho. Os valores obtidos da densitometria foram normalizados de acordo com os valores obtidos para a marcação com SYBR Green Gold.

\subsection{Quantificação de melanina}

Para quantificar a quantidade de melanina existente entre Skmel-28 e Skmel-37, o extrato proteico total destas linhagens foi extraído de acordo com o protocolo de extração descrito acima. Como referência, foi-se usado o extrato proteico da linhagem de melanoma Skmel-188, a qual apresenta pigmentação de melanina visível em cultura 
celular. Para se determinar a quantidade relativa de melanina nas linhagens, o extrato proteico obtido foi lido sob os espectros de 400 e $470 \mathrm{~nm}$ utilizando-se NanoDrop, espectros estes como utilizados para mensurar a melanina (Hosoi et al., 1985). O resultado obtido foi normalizado pela quantidade total de proteína também mensurada da mesma maneira, no entanto utilizando-se do espectro de $580 \mathrm{~nm}$.

\subsection{Uso de pifitrina- $\alpha$}

Pifithrin- $\alpha$ (PFT- $\alpha$ ) é um composto capaz de inibir a função transcricional de p53 (Komarov et al., 1995). PFT- $\alpha$ então foi usado para reverter o papel transcricional de p53 após exposição à UVB e cisplatina. Para tal, as células foram plaqueadas da mesma maneira descrita na seção 3.2 (Ensaios de Morte Celular). Como inibidor da atividade transcricional, pifithrin- $\alpha(30 \mu \mathrm{M})$ foi adicionado uma hora antes da exposição a UVB ou a adição de cisplatina. No caso específico de UVB, o meio foi substituído por HBSS para o momento da exposição. Após a irradiação, o meio foi recolocado novamente com PFT- $\alpha$. Para cisplatina, apenas foi adicionada o quimioterápico no meio já contendo PFT- $\alpha$. Como o ensaio de morte usando PFT- $\alpha$ foi averiguado após $48 \mathrm{~h}$ da exposição, seja à UVB ou cisplatina, o meio de cultura foi trocado após $24 \mathrm{~h}$, sendo este novo meio também contendo $30 \mu \mathrm{M}$ de PFT- $\alpha$. O controle foi tratado com DMSO, meio diluente para PFT- $\alpha$. A quantidade de DMSO foi de $0.5 \%$ $\mathrm{v} / \mathrm{v}$.

\subsection{Uso de Nutlin-3}

Para realçar a função de p53, optou-se por usar o composto Nutlin-3 nos ensaios que procuraram entender o papel de p53 na resposta à cisplatina. Nutlin-3 é um 
composto capaz de inibir a função de MDM-2 em ubiquitinar p53 (função essa que marca p53 à degradação) por interagir com o domínio de MDM-2 responsável pela função ligase (Vassilev et al., 2004). Para os ensaios de morte celular, as células foram plaqueadas da mesma maneira descrita na seção 3.2 (Ensaios de Morte Celular). As células foram tratadas com $12.5 \mu \mathrm{M}$ de cisplatina por $24 \mathrm{~h}$ e após este tempo deixada mais $24 \mathrm{~h}$ sem cisplatina, sendo então a morte analisada após $48 \mathrm{~h}$ do inicio do tratamento. Junto com o tratamento com cisplatina, as células foram tratadas com duas doses diferentes de Nutlin-3 (1 e $5 \mu \mathrm{M})$, adicionadas após cisplatina. Após a troca do meio para retirada de cisplatina, nova quantidade de Nutlin-3 também foi adicionada em novo meio. O controle foi tratado com DMSO, meio diluente para Nutlin-3. A quantidade de DMSO não foi superior a $1 \%$ v/v. A análise de morte foi realizada por FACS, conforme metodologia já descrita anteriormente.

Para o ensaio clonogênico, o mesmo ensaio foi realizado, porém após $48 \mathrm{~h}$ cerca de 300 células de cada ponto do ensaio foram contadas e plaqueadas em placas de 6 poços para crescimento de colônias. Após cerca de 2 semanas as colônias foram fixadas com solução $1 \%$ de paraformaldeído por 15 min e corados com $0.1 \%$ de cristal de violeta. O número de colônias após o tratamento indica a capacidade de sobrevivência e multiplicação das células após determinado tratamento. O numero de colônias foi quantificado a olho nu em cada condição.

\subsection{Análise de localização por imunofluorescência em microscopia confocal}

Cerca de $3 \times 10^{4}$ células foram plaqueadas em placa de 24 poços em condição de cultura, sobre lamínulas circulares de $13 \mathrm{~mm}$, e após $24 \mathrm{~h}$ foram irradiadas com dose de UVB a $120 \mathrm{~J} / \mathrm{m}^{2}$ para análise após 2,6 e $24 \mathrm{~h}$. As células foram fixadas em $3.5 \%$ de 
formaldeído em PBS. Em seguida, após serem lavadas 3x com PBS, foi adicionado Triton X-100/PBS $0.2 \%$ por 5 minutos. O bloqueio de sítios inespecíficos foi feito com PBS/BSA 5\% por 1 hora. Após isso, foi adicionado o anticorpo primário para hHR23B (1:100) diluído PBS-Tween $0.2 \%$ por período over night a $4^{\circ} \mathrm{C}$. No dia seguinte, depois de lavadas 3x com PBS-Tween 0.2\% incubou-se anticorpo primário contra XPC (1:100) diluído em PBS-Tween $0.2 \%$ novamente por $1 \mathrm{~h}$, a temperatura ambiente. Após o período, lavou-se por 3x novamente com PBS-Tween $0.2 \%$ por 10 min sendo em seguida adicionados os anticorpos secundários conjugados com Alexa Flúor 488 e 564 nm (Invitrogen 1:400) por 1h, de acordo com a origem do anticorpo primário. Após serem lavadas novamente com PBS-Tween $0.2 \%$, foi adicionado solução contendo DAPI, ou eventualmente Hoescht (ambos 1:400) por 15 minutos diluído em com PBS/BSA 5\%. Por último, foram montadas as lâminas. A análise foi realizada em microscópio confocal ZEISS LSM 510 Meta/UV. A calibração do equipamento foi feita de modo a não haver excesso de intensidade de fluorescência captada pelo microscópio nos ensaios onde há tratamento com UV, pois é onde se espera que haja maior intensidade de fluorescência em todas as marcações realizadas.

Para a análise da marcação de pontos de $\gamma-\mathrm{H} 2 \mathrm{AX}$, o mesmo procedimento acima descrito também foi feito, sendo, no entanto, a análise feita após 24 e 48 h após irradiação com UVB a $120 \mathrm{~J} / \mathrm{m}^{2}$. A montagem das lâminas também foi realizada da mesma maneira descrita. A análise também foi realizada por microscopia confocal, onde a calibração do equipamento foi adequada para o mínimo de fluorescência nas amostras controles, a fim de captar apenas foci fluorescentes correspondentes à marcação de $\gamma$-H2AX. Para a análise, 100 células foram identificadas para cada ponto do experimento (ctl, 24h e 48h) e o numero de foci correspondentes à marcação de $\gamma$ - 
H2AX foram contabilizados. Para análise estatística, os números de foci foram agrupados como: 0 a 5, 6 a 10, 11 a 15, 16 a 20 e mais de 20 foci.

\subsection{Ensaio Caspase 3/7}

Para analisar a ativação de caspases foi-se utilizado o kit Vybrant-FAM (Life Technologies) para detecção da ativação de caspase 3/7. Para tal, $1.2 \times 10^{5}$ células foram plaqueadas em placa de 6 poços e após $24 \mathrm{~h}$ foram expostas a $120 \mathrm{~J} / \mathrm{m}^{2}$ de UVB. Após irradiação dos tempos determinados (24 e 48h), o sobrenadante foi descartado e as células ainda aderidas foram tripsinizadas e ressuspensas em PBS. Cerca de $4 \times 10^{4}$ células de cada ponto foram contadas e ressuspensas em $100 \mu 1$ de PBS, adicionando-se o reagente de detecção da atividade caspase, seguindo concentração indicada pelo fabricante. $\mathrm{O}$ eppendorf contendo as células foi colocado em estufa de $\mathrm{CO}_{2}$ por 1 hora, sendo em seguida as células centrifugadas e lavadas com solução wash buffer do kit. O pellet resultante foi suspenso em PBS e incubado com solução de Iodeto de Propídeo (proveniente do kit) no gelo por 5 min. Em seguida, as células foram analisadas por citometria de fluxo (FACScalibur Becton Dickson). A análise da ativação de caspase se deu pelos resultados de deslocamento de eventos em comparação com o controle, através do filtro em FL-1 (excitação verde). A análise quantitativa da ativação de caspase foi baseada na média da intensidade de fluorescência, medida pela média geométrica obtida pelo histograma da fluorescência.

A metodologia e análise da ativação de caspase $3 / 7$ na exposição à cisplatina foi realizada da mesma maneira descrita. Neste caso em específico, as células foram tratadas com $12.5 \mu \mathrm{M}$ de cisplatina por $24 \mathrm{~h}$. Um dos pontos observados foi após $24 \mathrm{~h}$ de exposição à cisplatina, enquanto outro ponto foi de $24 \mathrm{~h}$ após as primeiras $24 \mathrm{~h}$ de 
exposição à cisplatina, da mesma maneira realizada para análise de morte celular descrita acima.

3.13 Ensaio de detecção de espécies reativas de oxigênio (ROS) por DHR e uso de Tempol e Catalase na sensibilidade à UVB

Para detecção de espécies reativas de oxigênio após a exposição à UVB, foi usada a detecção da fluorescência emitida por DHR (Dihydrorhodamine 123). O DHR é um indicador de espécies reativas de oxigênio inicialmente não oxidado que pode difundir passivamente através das membranas celulares, onde dentro do citoplasma pode ser oxidado por ROS e emitir fluorescência no espectro verde. Para este ensaio, cerca de $3.5 \times 10^{4}$ células foram plaqueadas em placas de 12 poços e após $24 \mathrm{~h}$ irradiadas com UVB a $120 \mathrm{~J} / \mathrm{m}^{2}$. Para exposição, as células na placa tiveram o meio retirado, sendo substituído por solução HBSS 1x (Hank's Buffered Salt Solution). Após a irradiação, o HBSS foi retirado, sendo substituído por meio RPMI ou MEM (para Skmel-37) acrescido de 10\% SFB.

Trinta minutos antes do término do tempo de exposição a ser analisado (24h e 48h), o meio e o sobrenadante foram retirados e novo meio contendo $15 \mu \mathrm{M}$ de DHR foi adicionado. As placas então foram recolocadas em estufa de $\mathrm{CO}_{2}$ por $30 \mathrm{~min}$. Após esse tempo, as células foram tripsinizadas, centrifugadas para formação de pellet e o mesmo ressuspenso em PBS. As amostras foram analisadas quanto à emissão de fluorescência em citometria de fluxo. A análise quantitativa da produção de espécies reativas foi baseada na média da intensidade de fluorescência, medida pela média geométrica obtida pelo histograma da fluorescência. 
O uso de neutralizadores de espécies reativas como Tempol (4-HydroxyTEMPO)(Sigma Aldrich) e Catalase (Sigma Aldrich) foi usado para testar o papel de espécies reativas na sensibilidade à UVB. Tempol foi diluído em água à concentração de $1 \mathrm{M}$ e usado em concentrações de 0.2 e $2 \mathrm{mM}$. Catalase foi diluída em tampão fosfato (Fosfato de Potássio $50 \mathrm{mM}$ pH 7.0). As concentrações de uso foram de 50 e $500 \mathrm{U}$. Para o ensaio com uso de Tempol ou Catalase, cerca de $3.5 \times 10^{4}$ células foram plaqueadas em placas de 12 poços e após $24 \mathrm{~h}$ irradiadas com UVB a $120 \mathrm{~J} / \mathrm{m}^{2}$. Após a irradiação foi adicionado as concentrações de acima citadas de Tempol ou Catalase, sendo após 48h as células tripsinizadas e analisadas para morte celular em FACS.

3.14 Transdução da linhagem Skmel-28 com vetor p53 e GFP e experimento de proporção populacional em população mista

Para confirmar o papel de p53 após exposição à UVB e/ou cisplatina, optou-se por restaurar a atividade de p53 na linhagem Skmel-28, a qual possui mutação descrita na literatura (R145L). Para tal, utilizou-se de transdução viral com vetor desenvolvido para expressão da proteína p53 tendo como controle transcricional um promotor responsivo a p53. Tal vetor foi desenvolvido e testado pelo grupo do Dr. Bryan Strauss, mostrando interessantes resultados de restauração da atividade p53 (Strauss \& CostanziStrauss, 2004; Strauss et al., 2005).

Para a metodologia de transdução, cerca de $10^{5}$ células foram plaqueadas em poço de placa de 6 poços em $1.5 \mathrm{ml}$ de meio RPMI acrescido de $10 \%$ de SFB. As células plaqueadas foram deixadas em estufa de $\mathrm{CO}_{2}$ a $37^{\circ} \mathrm{C}$. No dia seguinte, o meio foi retirado e foi-se adicionado 600-700 $\mu \mathrm{l}$ de meio de cultura contendo o vetor lentiviral previamente produzido suplementado com $8 \mu \mathrm{l} / \mathrm{ml}$ de polibreno. No poço para 
controle negativo, apenas meio contendo $8 \mu \mathrm{l} / \mathrm{ml}$ de polibreno. As células foram deixadas expostas ao vetor por cerca de 6-8 horas, sendo após esse período adicionado 1 $\mathrm{ml}$ de meio fresco. Como a expressão do transgene pode ser observada após $48 \mathrm{~h}$ da transdução, as células transduzidas foram deixadas por 2 dias, sendo após esse período iniciado a seleção por antibiótico. As células foram mantidas com $80 \mu \mathrm{g} / \mathrm{ml}$ de antibiótico Geneticina (G418) até a total eliminação do controle negativo. Após a seleção as células foram expandidas e utilizadas para os experimentos necessários, sempre mantidas na concentração de $80 \mu \mathrm{g} / \mathrm{ml}$ de geneticina, exceto no momento do experimento, onde foi apenas utilizado meio de cultura livre de antibiótico. Além das células expressando p53, as células controles de transfecção apresentaram vetor vazio (mock) ou, em alguns experimentos necessários, expressão de GFP.

Para o ensaio de proporção populacional após exposição à cisplatina utilizou-se as duas populações de células, a população expressando p53 e população expressando GFP. As duas populações foram tripsinizadas e contadas para cerca de $1.5 \times 10^{4}$ células de cada população, as quais foram plaqueadas em placa de 12 poços, estando no final a proporção de 1:1 de cada subpopulação. As populações teste foram expostas a $12.5 \mu \mathrm{M}$ de cisplatina por $24 \mathrm{~h}$ e após $24 \mathrm{~h}$, o meio com cisplatina retirado e reposto por meio livre do quimioterápico. A proporção de células expressando p53 ou GFP foi analisada após os tempos de 48h, 72h e 96h após exposição à cisplatina. A análise foi feita em FACS, sendo as células controles e tratadas nos respectivos tempos, tripzinizadas, homogeneizadas e resuspensas em PBS para análise no citômetro. A análise constou na proporção de eventos em cada um dos dois quadrantes estabelecidos, uma vez que a população expressando apenas GFP apresentava deslocamento à direita no canal FL-1 
(verde), enquanto as células expressando p53 se apresentavam situadas à esquerda. $\mathrm{O}$ numero de eventos foi contabilizado e colocado em gráfico e analisado estatisticamente.

Para os demais experimentos realizados com as duas populações, a metodologia usada foi a mesma descrita para os ensaios já realizados com Skmel-28 e Skmel-37.

\subsection{Tratamento com 5'AZA- 2' -deoxicitidina}

Para tratamento com o agente inibidor de enzimas DNA metilases 5' AZA-2' deoxicitidina ( $5^{\prime}$ AZA), 5 × $10^{5}$ células foram plaqueadas em garrafas de $25 \mathrm{~cm}^{2}$. Após 24h de cultivo, as células foram tratados com $5 \mu \mathrm{M}$ de 5' AZA (Sigma Aldrich) por 72h. Durante tal período, o meio foi trocado a cada $24 \mathrm{~h}$, sendo adicionado novamente a mesma concentração de $5 \mu \mathrm{M}$ de 5 ' AZA a cada troca de meio. O controle foi tratado com DMSO, o diluente usado na solução de 5' AZA. A relação volume/volume (v/v) para a solução contendo DMSO não ultrapassou $0.5 \%$ do volume total. Após as $72 \mathrm{~h}$ de tratamento, as células contidas nas garrafas de $25 \mathrm{~cm}^{2}$ foram tripsinizadas e centrifugadas. O sobrenadante foi descartado e o pellet de células foi resuspenso em tampão RIPA para extração de proteínas.

\subsection{Extração de RNA}

Para análises de quantificação da expressão gênica foi utilizada a técnica de qRT-PCR. Inicialmente o mRNA das linhagens celulares foi extraído através do reagente TRIZOL (Life Technologies). Brevemente, após a adição de $1 \mathrm{ml}$ de Trizol, a solução foi transferida para tubos eppendorf de $1.5 \mathrm{ml}$ para homogeneização por $5 \mathrm{~min}$ a temperatura ambiente. Em seguida foi adicionado $200 \mu \mathrm{l}$ de clorofórmio para denaturação das proteínas. Após 2 min de incubação, as amostras foram centrifugadas a $12.000 \mathrm{rpm}$ por $15 \mathrm{~min} \mathrm{a} 4^{\circ} \mathrm{C}$ sendo a fase aquosa (fase superior) transferida para tubos 
novos. Em seguida, $500 \mu \mathrm{l}$ de isopropanol foram adicionados e incubados $15 \mathrm{~min}$ a temperatura ambiente. Logo após, centrifugou-se a $11.000 \mathrm{rpm}$ por $10 \mathrm{~min}$, o sobrenadante removido e o pellet lavado com $1 \mathrm{ml}$ de etanol 75\%. As amostras foram centrifugadas a $7.500 \mathrm{rpm}$ por 5 min e o pellet dissolvido em água ultrapura (RNase free). $\mathrm{O}$ pellet resultante foi homogeneizado a $60^{\circ} \mathrm{C}$ por $10 \mathrm{~min}$. As amostras foram estocadas a $-70^{\circ} \mathrm{C}$ até o momento do uso.

A quantificação do RNA extraído foi determinada por espectrofotometria, sendo a integridade do RNA total verificada através da visualização de bandas ribossomais 28S e 18S. Para tal, o RNA foi submetido à eletroforese em gel de agarose $0.8 \%$ em tampão MOPS (200 mM MOPS, $10 \mathrm{mM}$ EDTA, $50 \mathrm{mM}$ Acetato de Sódio). A visualização das bandas se deu por ultravioleta em trans-iluminador (ImageMaster, Pharmacia) coradas com brometo de etídio.

\subsection{Síntese de cDNA}

A síntese de cDNA a partir de RNA foi realizada utilizando-se o kit Superscrpt III (Life Technologies) e seguindo o protocolo do fabricante. Brevemente, $1 \mu \mathrm{g}$ de RNA foi adicionado a $1 \mu \mathrm{l}$ de oligo dT $500 \mu \mathrm{g} / \mathrm{ml}$ (Life Technologies) e $1 \mu \mathrm{lde}$ dNTP mix 10 mM (Life Technologies) em tubo de $200 \mu$ l e água ultra pura q.s.p. $13 \mu$ l. Os reagentes então foram incubados a $65^{\circ} \mathrm{C}$ por 5 min. Imediatamente após esse período, as amostras foram resfriadas em gelo. Em seguida foi adicionado 7 ul de mix contendo: $4 \mu \mathrm{de}$ tampão first-strand 5X (Life Technologies), $2 \mu 1$ de DTT $0.1 \mathrm{M}$ (Life Technologies), 1 $\mu 1$ de Superscript III (Life Technologies) e $1 \mu 1$ de RNase inhibitor (Life Technologies). As amostras foram incubadas por $1 \mathrm{~h}$ a $50^{\circ} \mathrm{C}$ seguidos de 15 min a $75^{\circ} \mathrm{C}$. O cDNA resultante foi estocado a $-20^{\circ} \mathrm{C}$. 


\subsection{Análise da expressão gênica por quantitative RT-PCR (qRT-PCR)}

Para a reação de qRT-PCR utilizou-se a metodologia do SYBR-Green, na qual um fluoróforo é capaz de se ligar ao DNA dupla fita, aumentando sua fluorescência ao longo da reação. Os valores quantitativos foram obtidos no ponto no qual a fluorescência emitida ultrapassou um limiar de detecção estabelecido de 0.2 (CT: Cycle Treshold), ou seja, no ponto no qual a amplificação do produto foi detectada. Os dados de quantificação obtidos foram analisados pelo software de análise do aparelho Rotor Gene 3000 (Corbett Life Science).

Para a reação de real time foi utilizado um volume final de $20 \mu 1$ de reação contendo tampão de reação $1 \mathrm{x}$ (Life Technologies), $1.5 \mathrm{mM}$ de $\mathrm{MgCl}_{2}$ (Life Technologies), 1U Taq Platinum (Life Technologies), $10 \mu \mathrm{M}$ de dNTPs (Life Technologies), $0.3 \mu \mathrm{M}$ de primer senso e $0.3 \mu \mathrm{M}$ de primer anti-senso, $1 \%$ de SYBR Green 1:100 (Life Technologies) e 5\% de DMSO (dimetil sulfóxido, SIGMA). Os primers utilizados foram: para hHR23B (senso 5'CAGATAGGTCGAGAGAATCCTCAAT-3', anti-senso 5'ATCTGAATAAAATGCTCCTGGTGTT-3'), hHR23A (senso 5'GAACCCTCAGCTTTTACAGCAAA-3', anti-senso 5'GGCTCGTTCAGCATCTGGAT-3'), $\quad \beta$-actina $\quad$ (senso $\quad$ 'AGAAAATCTGGCACCACACC-3', anti-senso 5'-AGAGGCGTACAGGGATAGCA3'), XPC (senso 5'-TCTTCGGAGGGCGATGAAAC-3', anti-senso 5'ATGATGGACAGGCCAATAGC-3').

As condições de amplificação foram as seguintes: $95^{\circ} \mathrm{C}$ por 5 minutos seguidos de 35 ciclos de $95^{\circ} \mathrm{C}$ por 30 segundos, $60^{\circ} \mathrm{C}$ por 30 segundos e, por fim, $72^{\circ} \mathrm{C}$ por 30 segundos. Uma etapa final, na qual a temperatura aumenta gradualmente de $72^{\circ} \mathrm{C}$ para 
$95^{\circ} \mathrm{C}$ a $1^{\circ} \mathrm{C}$ a cada 5 seg com a contínua aquisição da fluorescência, foi adicionada ao fim da amplificação para submeter os produtos amplificados a uma curva de dissociação.

A expressão diferencial dos genes a serem avaliados (transcrito alvo) foi determinada através do método de quantificação relativa em relação a um controle endógeno ou gene normalizador, no caso, a $\beta$-actina. Para o cálculo da expressão diferencial foi utilizado o modelo matemático proposto por Pfaffl (2001), seguindo a fórmula:

$$
\mathbf{R}=\frac{(E \text { alvo })^{\Delta C T} \text { alvo (amostra } \text { referência/amostra alvo) }}{(E \text { normalizador })^{\Delta C T \text { normalizador }} \text { (amostra referência/amostra alvo) }}
$$

Onde:

$\boldsymbol{E}$ alvo: Eficiência de amplificação dos primers específicos para o transcrito alvo;

$\boldsymbol{E}$ normalizador: Eficiência de amplificação dos primers específicos para o gene normalizador, no caso $\beta$-actina;

$\Delta$ CT alvo: Corresponde à diferença entre o CT obtido dos genes avaliados para a amostra de referência (controle) e do CT dos genes avaliados obtidos para a amostra em análise (condição experimental);

$\Delta \mathbf{C T}$ normalizador: Corresponde à diferença entre o CT da $\beta$-actina obtido para a amostra de referência (controle) e do CT obtido da $\beta$-actina para a amostra em análise (condição experimental).

As eficiências de amplificação dos primers foram calculadas de acordo com a equação: 


$$
\mathrm{E}=10^{(-1 / \text { slope })}
$$

Onde o Slope corresponde à inclinação da reta obtida quando se analisa a variação do CT do transcrito alvo e do normalizador em função do $l o g$ de diferentes quantidades de cDNA. A eficiência de amplificação dos primers usados já foi previamente calculada, seja na rotina do laboratório.

3.19 Silenciamento gênico por siRNA e experimentos de reparo de lesões UVB e sensibilidade a UVB e quimioterápicos

Foi-se utilizado também metodologia de silenciamento gênico por uso de siRNAs, de carácter transiente. Optou-se por usar oligos esiRNA (Sigma Aldrich) para o silenciamento transiente. Este tipo de siRNA é composto de diversos oligos preparados por metodologia de endorribonuclease, gerando assim uma mistura heterogênea de siRNA para uma mesma sequiência alvo. Esta metodologia facilita o silenciamento gênico ao mesmo tempo em que diminui a possibilidade de off-targets, conseqüência possível da aplicação de uma única seqüência de siRNA. Desta maneira usou-se esiRNA para hHR23B, XPC e como controle negativo, esiRNA para o gene Luciferase (Luc1) (Sigma Aldrich).

Para transfecção, $3.5 \times 10^{5}$ células Skmel-37 foram plaqueadas em placas de 70 mm e após 24h, as placas foram lavadas 2x com PBS e em seguida colocado $2.6 \mathrm{ml}$ de OPTIMEM pH 7.2. Paralelamente, $200 \mu$ de OPTIMEM foi colocado em tubos eppendorf e acrescido $10 \mu \mathrm{d}$ de Olifofectamina (Invitrogen)(quantidade normalmente usada para transfecções de siRNA no laboratório). Em outro tubo eppendorf com a mesma quantidade de OPTIMEM, foi colocado esiRNA. Ambos tubos foram deixados em repouso por 5 min e em seguida misturados e deixados para formação dos 
complexos contendo oligofectamina + esiRNAs por $20 \mathrm{~min}$ (conforme protocolo do fabricante). Após o tempo de formação dos complexos, os $400 \mu$ resultantes foram colocados por gotejamento nas placas de $70 \mathrm{~mm}$ contendo as células. As células foram então colocadas em estufa e após 6 h foi adicionado $10 \%$ de SFB.

Após $24 \mathrm{~h}$ da transfecção, as células foram tripsinizadas e contadas para plaqueamentos posteriores. O restante das células foi recolhido para extração de RNA para confirmação do silenciamento. Primeiramente foi feito padronização para a quantidade de esiRNA a ser usada no silenciamento. Para confirmação do efeito do silenciamento por esiRNA, o RNA extraído foi convertido em cDNA e a expressão do gene alvo mensurada através de Real-Time PCR. A metodologia para conversão de RNA em cDNA e de Real-Time PCR foi a mesma utilizada e descrita acima.

Para ensaios de sensibilidade a UVB e quimioterápicos, 24h após transfecção (quantidade de $1.2 \mu \mathrm{g}$ de esiRNA), cerca de $3.5 \times 10^{4}$ células foram plaqueadas em placas de 12 wells e após 24 h de plaqueamento foram tratadas, seja por irradiação com UVB (doses de 60 e $120 \mathrm{~J} / \mathrm{m}^{2}$ ) ou com os agentes quimioterápicos descritos abaixo. Após $48 \mathrm{~h}$ de tratamentos, as células e o sobrenadante foram recolhidos para análise de morte por incorporação de iodeto de propídio, conforme descrito acima para tal procedimento. Para a exposição à UVB, após 48h do tratamento, 300 células do componente aderente foram plaqueadas em placas de 6 wells para ensaios de sobrevivência. Após cerca de uma semana as colônias foram fixadas com solução 3.7\% de paraformaldeído por 15 min e corados com $0.1 \%$ de cristal de violeta. O número de colônias após o tratamento indica a capacidade de sobrevivência e multiplicação das células após determinado tratamento. O número de colônias foi quantificado a olho nu em cada condição. Nos ensaios onde houve extração de proteínas, 3.5 x $10^{5}$ células 
Skmel-37 foram plaqueadas em placas de $70 \mathrm{~mm}$ e após $24 \mathrm{~h}$ transfectadas com esiRNA (concentração de $1.2 \mu \mathrm{g}$ de esiRNA) as células foram plaqueadas em placas de 6 wells na quantidade de $1.25 \times 10^{5}$ e após 24 h foram realizados os ensaios descritos. Após os tempos estipulados, as células foram tripsinizadas para extração de proteínas totais, utilizando-se metodologia já descrita para extração. Para os ensaios de western blottings, a quantidade de proteína aplicada variou-se de 40-50 ng.

Para ensaios de cinética de reparo de DNA, 5 x $10^{5}$ células em placas de $100 \mathrm{~mm}$ foram transfectadas para esiRNA ( $2 \mu \mathrm{g}$ de esiRNA) e após $24 \mathrm{~h}, 1.2$ × $10^{5}$ células foram plaqueadas em placas de 6 wells. Após $24 \mathrm{~h}$ de plaqueamento, as células foram irradiadas com UVB a $120 \mathrm{~J} / \mathrm{m}^{2}$. Foram plaqueadas em 4 poços (ctl neg, 0h, 6h e 24h). Após os tempos indicados, as células foram tripsinizadas e o DNA extraído conforme descrito na seção 3.8. A metodologia de avaliação da eficiência de reparo de lesões CPD e 6-4PP nas células knock-down para hHR23B e XPC é similar a descrita na seção 3.8.

\subsection{Sensibilidade a agentes quimioterápicos}

Para testar o papel de hHR23B na resistência e resposta a agentes quimioterápicos, $3.5 \times 10^{4}$ células previamente transfectadas com esiRNA foram plaqueadas em placa de 12 wells e após 24 h horas (início do tratamento a 48 h após transfecção) foram expostas a diferentes agentes quimioterápicos por $48 \mathrm{~h}$. Após este período de exposição, o sobrenadante a as células ainda aderidas foram recolhidas para análise de morte celular por incorporação de iodeto de propídio por citometria de fluxo. Os agentes quimioterápicos utilizados e a concentração final foram: Cisplatina (12.5 $\mu \mathrm{M}$ - Sigma Aldrich), Doxorrubicina (100 ng/ml - Sigma Aldrich), Dacarbazina (20 $\mu \mathrm{M}$ Sigma Aldrich), Etoposideo (1 $\mu \mathrm{M}$ - Sigma Aldrich), Temozolomida (100 $\mu \mathrm{M}$ - Sigma 
Aldrich), 5’Fluoracil (10 $\mu \mathrm{M}$ - Sigma Aldrich), e Tunicamicina (300 e $500 \mu \mathrm{M}$ - Sigma

Aldrich). Exceto para cisplatina, todos os demais quimioterápicos foram diluídos em DMSO, sendo a relação volume/volume (v:v) não ultrapassando $0.5 \%$ do volume de meio.

3.21 Análise imunohistoquimica para expressão de hHR23B em amostras de origem melanocíticas

Para análise da expressão de hHR23B em amostras de origem melanocíticas, foi adquirido Melanoma $T M A$ array, NCI (http://cdp.nci.nih.gov/melanoma/melanoma.html) de acordo com projeto colaborativo estabelecido por R. Chammas e R.J. Gilles (H. Lee Moffitt, Câncer Center). As lâminas de TMA adquiridas são compostas por 4 lâminas contendo respectivamente séries névicas, melanomas primários, metástases lifonodais de melanomas cutâneos e metástases viscerais de melanomas cutâneos. O processo de imunohistoquímica foi feito com anticorpo anti-hHR23B (Santa Cruz) e revelado com sistema dependente de atividade de fosfatase alcalina (cromógeno vermelho) e contracorado com hematoxilina de Harris.

\subsection{Extração de DNA e genotipagem quanto aos polimorfismos de XPC}

A extração de DNA das linhagens de melanoma existentes no laboratório ocorreu de acordo com protocolo previamente estabelecido no laboratório. Brevemente, células de uma garrafa pequena $\left(25 \mathrm{~cm}^{2}\right)$ foram tripsinizadas e recolhidas em tubo falcon de $15 \mathrm{ml}$ e precipitadas por centrifugação a $2000 \mathrm{~g}$ por $2 \mathrm{~min}$. O pellet resultante foi lisado com solução contendo $2 \%$ SDS, 25 mM EDTA pH 8.0 e a solução homogeneizada por vortex e incubada overnight a $37^{\circ} \mathrm{C}$. Em seguida a solução foi 
mantida a temperatura ambiente por $1 \mathrm{~h}$ sendo em seguida adicionada solução para precipitação de proteínas (10M acetato de amônia). A solução foi passada pelo vortex e em seguida deixada 15 min em gelo. Após incubação em gelo, a solução foi centrifugada a $2000 \mathrm{~g}$ por 15 min e o supernadante retirado e colocado em tubo novo contendo $500 \mathrm{ml}$ de isopropanol $100 \%$ para precipitação em temperatura ambiente por 15 min.

Após a centrifugação, o supernadante foi descartado por e o pellet resultante de DNA lavado com etanol $70 \%$, sendo em seguida centrifugado novamente por $2000 \mathrm{~g}$ por 15 min. Em seguida, retirou-se o sobrenadante, deixando o tubo secar a temperatura ambiente e o pellet de DNA foi finalmente ressuspenso em DNA a $65^{\circ} \mathrm{C}$ por $10 \mathrm{~min}$. A quantidade de DNA foi mensurada por nanodrop.

O método escolhido para genotipagem foi a Reação em Cadeia da Polimerase (PCR - polymerase chain reaction) seguida de restrição. Através de tal reação seria possível à amplificação específica da região de DNA que apresentasse o alelo polimórfico dos genes de interesse no estudo. A utilização das concentrações dos reagentes bem como das condições de amplificações foram otimizadas de maneira a produzirem um produto amplificado único e de grande intensidade quando observado em gel de agarose sob luz UV, de maneira a possibilitar a genotipagem correta das amostras nos passos posteriores.

Quanto à utilização dos reagentes, as reações de PCR foram realizadas, com concentrações finais: 1x Buffer da enzima Taq Dna polimerase, $1.5 \mathrm{mM}$ de $\mathrm{MgCl}_{2}, 0.2$ $\mathrm{mM}$ de dNTP Mix, $0.3 \mathrm{mM}$ de primer senso, $0.3 \mathrm{mM}$ de primer anti-senso, $1 \mathrm{U}$ enzima Taq Dna polimerase (Invitrogen), concentração de 100 a 200 ng de DNA das amostras e 
água MilliQ autoclavada q.s.p. $20 \mu \mathrm{l}$, o volume final da reação. Todos reagentes colocados em tubo tipo Eppendorf de $0.2 \mathrm{ml}$.

Uma vez terminada a montagem da reação, as amostras foram levadas ao termociclador (PCR System 9700 - Applied Biosystem) onde as condições da amplificação foram otimizadas para: 1 ciclo de $94^{\circ} \mathrm{C}$ por 5 min para desnaturação completa do DNA, seguido de 40 ciclos de 30 s a $94^{\circ} \mathrm{C}, 30$ s de temperatura de associação dos primers, cuja temperatura variou de acordo com a composição das bases (Tabela 1) e 30s a $72^{\circ}$ para amplificação dos produtos. Seguiu-se após o termino dos 40 ciclos, uma extensão final de 5 min a $72^{\circ} \mathrm{C}$.

Após o termino da reação de PCR, as amostras foram conferidas para a adequada amplificação em gel de agarose $1.5 \%$ já corado previamente com Brometo de Etídio e submetidas à eletroforese por cerca de $1 \mathrm{~h}$ a $120 \mathrm{~V}$. Após a eletroforese, o gel foi visto sob luz UV e em seguida fotografado utilizando-se para isso o equipamento Image Master (Pharmacia Biotech) disponível no laboratório de Oncologia Experimental da FMUSP. Todos os géis continham um marcador de peso molecular 100 bp (Invitrogen) para confirmação da amplificação do tamanho esperado para determinado gene. Para o polimorfismo de XPC PAT, o próprio produto de PCR já indicava o genótipo da amostra, isso porque tal variante alélica consiste da presença ou ausência de uma região de 83 pares de bases de repetições AT. Assim, se a linhagem fosse homozigoto para ausência do poli AT (-/-) o produto amplificado deveria ser uma banda única de 266 bp, enquanto se fosse homozigoto para a presença de poli AT (+/+) deveria apresentar banda única de 344 bp. Já o genótipo heterozigoto apresentaria as duas bandas. Existe um erro no tamanho do amplificado que contém a região de 83 AT, pois a soma não corresponderia a 344 e sim a 349. A explicação está no fato de que a 
inserção desta região de 83 pares de bases ocasiona necessariamente a deleção de 5 pares de bases do intron 9 de XPC (Khan et al. 2000).

Uma vez que a amplificação dos DNAs foi adequada, o passo posterior foi genotipar as amostras quanto a seu haplótipo nos genes abordados no estudo. Para tal, foi abordada a metodologia de restrição dos fragmentos através do uso de enzimas de restrição. Tal metodologia é conhecida como RFLP (Restrinction Fragment Lenght Polymorphism). A escolha de tal método é devido ao efeito que a substituição de bases no DNA causa em sítios de restrição de enzimas, assim o polimorfismo de uma base pode criar ou mesmo retirar um sítio de restrição podendo então ser usada uma determinada enzima para a correta genotipagem.

A reação de restrição foi realizada utilizando-se cerca de $1 \mu \mathrm{g}$ do produto amplificado por PCR, 1x Buffer da Enzima a ser utilizada, $1 \mathrm{U}$ da enzima adequada para cada polimorfismo (Tabela 1) e água MilliQ autoclavada na quantidade suficiente para completar $10 \mu \mathrm{l}$ de reação, volume final, sendo todos os reagentes colocados em tubo tipo Eppendorf. A restrição se deu em banho seco por cerca de $2 \mathrm{~h}$, onde a temperatura variou de acordo com a temperatura ideal de cada enzima. Após o termino da reação, o produto obtido foi colocado em gel de agarose $1.5 \%$ corado com Brometo de Etídio e submetido à eletroforese por cerca de $1 \mathrm{~h}$ a $120 \mathrm{~V}$. Em seguida o gel foi visualizado sob luz UV e fotografado. Com auxilío da fotografia, a genotipagem das amostras foi anotada de acordo com o padrão de restrição obtido e previamente determinado. Um marcador molecular de 100 bp (Invitrogen) também foi colocado em todos os géis de agarose para confirmação dos tamanhos dos fragmentos. 
A genotipagem das amostras foi realizada através do tamanho dos produtos resultantes da restrição, onde o padrão esperado para cada genótipo pode ser conferido na Tabela 1.

Tabela 1. Primers, condições de PCR e restrição para os polimorfismos de $X P C$

\begin{tabular}{|c|c|c|c|c|c|c|}
\hline gene (SNP) & Primers $\left(5^{\prime} \rightarrow 3^{\prime}\right)$ & Temp ${ }^{\circ} \mathrm{C}$ & RFLP & \multicolumn{3}{|c|}{ Tamanho esperado (bp) } \\
\hline \multirow[t]{2}{*}{ XPC poli AT -/+ } & F - TAGCACCCAGCAGTCAAAG & 56 & & $(-/-)$ & $(+/-)$ & $(+/+)$ \\
\hline & R - TGTGAATGTGCTTAATGCTG & & & 266 & $344 / 266$ & 344 \\
\hline \multirow[t]{2}{*}{ XPC K939Q } & F- GGAGGTGGACTCTCTTCTGATG & 58 & Pvu II & KK & KQ & QQ \\
\hline & R- TAGATCCAAGCAGATGACC & & & 765 & $765 / 585 / 180$ & $585 / 180$ \\
\hline \multirow[t]{2}{*}{ XPCIV11-5 C/A } & F- AAATGACCTGGGCCTGTTTG & 63 & Fau I & $\mathrm{CC}$ & $\mathrm{CA}$ & AA \\
\hline & R-GGCAGGAAGAGGTACACATTC & & & $160 / 43$ & $203 / 160 / 43$ & 203 \\
\hline
\end{tabular}

\subsection{Análise de Expressão alelo-específica de XPC}

Para análise de expressão alelo-especifica, as linhagens heterozigotas para XPC K939Q (LB373, Mel85, MZ2-MEL, Skmel-02 e Skmel-147), foram primeiramente plaqueadas em placas de $70 \mathrm{~mm}\left(3.5 \times 10^{5}\right.$ cels $)$ e após $24 \mathrm{~h}$ de plaqueamento as placas foram irradiadas com UVB à dose de $120 \mathrm{~J} / \mathrm{m}^{2}$ (dose comumente usada durante o projeto). Para tal, as placas tiveram o meio de cultura retirado e substituído por HBSS 1x, e em seguida irradiadas. Após a irradiação, as células foram novamente postas sob meio de cultura original e mantidas a estufa a $37^{\circ} \mathrm{C}$ e $5 \% \mathrm{CO}_{2}$ pelos tempos necessários. Para cada linhagem, foi-se realizado cinética de exposição à UVB, extraindo-se RNA de cada linhagem após 0, 2, 4, 6, 8 e 24h após irradiação. Para todas as linhagens heterozigotas, o ensaio foi realizado em triplicatas independentes. A metodologia de extração de RNA foi a mesma descrita anteriormente. As amostras foram tratadas com DNase I Amplification Grade (life Technologies) usando o seguinte protocolo: $5 \mu \mathrm{g}$ de RNA, $2 \mu \mathrm{g}$ de DNase I, $1 \mu \mathrm{l}$ de DNase I buffer e água DEPC para $10 \mu 1$. Incuba-se a 
reação a $37^{\circ} \mathrm{C}$ por 10 min e em seguida adiciona-se $1 \mu 1$ de EDTA $25 \mathrm{mM}$ para termino da reação e em seguida aquece-se a reação a $65^{\circ} \mathrm{C}$ por $5 \mathrm{~min}$. Após tratamento com DNase I, cerca de $2 \mu \mathrm{g}$ de RNA foi usada para conversão em cDNA, conforme descrito anteriormente.

Para a avaliação da expressão alelo-específica, optou-se por usar a metodologia de Taqman, utilizando-se sondas específicas para cada alelo de XPC (alelo K e alelo Q). As sondas utilizadas, já constam de metodologia utilizada e padronizada usualmente para genotipagem de polimorfismos (Life Technologies), desta maneira aproveitando-as para o uso de expressão alelo-específica. As reações de quantificação alelo-específica foram realizadas em duplicata em placas de 96 poços, em reações contendo $1 \mu$ de cDNA (50 ng), $6.25 \mu \mathrm{l}$ de TaqMan Universal Master Mix (Life Technologies ${ }^{\circledR}$ ), 0.625 $\mu 1$ Kit Taqman sonda XPC e $\mathrm{H}_{2} \mathrm{O}$ Milli Q q.s.p. $12.5 \mu$ l. Para auxilio e referência na hora de calcular as diferenças de expressão alelo-específica, junto de cada reação realizada foi feito uma curva-padrão das amostras de DNA genômico homozigotas para os alelos KK e QQ, nas seguintes diluições 4:1, 3:1, 2:1, 1:1, 1:2, 1:3, 1:4, respectivamente, todas com a concentração de 50 ng de DNA. Esta metodologia foi baseada em experimentos prévios já publicados (Lo et al., 2003). A intensidade do sinal de fluorescência de FAM (alelo selvagem-K) e VIC (alelo raro-Q) foi captada no termociclador Applied Biosystems 7900HT Fast Real-Time PCR. As amostras foram quantificadas pelo programa Quantification (Life Technologies ${ }^{\circledR}$ ).

\subsection{Cálculos para análise de expressão alelo-específica de XPC K939Q}

Para a análise do resultado da expressão alelo-específica de XPC K939Q, houve a necessidade de se elaborar um conjunto de cálculos para se chegar à possível diferença 
de expressão de cada alelo. Tal metodologia foi baseada em trabalhos publicados anteriormente e que já haviam desenvolvido tal metodologia (Lo et al., 2003; Pillay et al., 2012). Inicialmente, houve a necessidade de se construir uma curva padrão com diferentes pontos de concentração dos alelos K e Q. Para tal, amostras de DNA de linfócitos de um banco originalmente usadas em projetos anteriores foram genotipadas para identificação de amostras homozigotas para os alelos KK e QQ. Uma vez genotipadas, as amostras foram diluídas em $\mathrm{H}_{2} \mathrm{O}$ Milli Q para concentração final de 50 ng de DNA. A partir destas diluições, foi então construída a curva padrão a ser utilizada, a qual constou de diluições descritas acima.

Para análise da expressão alelo-específica, os dados do valor de fluorescência para cada alelo no ciclo 45 (metodologia usada por Lo et al., 2003) foram obtidos e plotados em tabela. A média das duplicatas para FAM (alelo K), ROX (normalizador interno) e VIC (alelo Q) foram obtidas. Para cada amostra, foi necessário normalizar a intensidade do sinal de FAM/ROX e VIC/ROX. A normalização também constou com a utilização de amostras de DNA genômico controle homozigota KK (FAM/FAM) e controle homozigota QQ (VIC/VIC), isto porque ensaios com sonda TaqMan podem apresentar sinal inespecífico de fluorescência.

Após esta normalização, a razão FAM/VIC (eixo X) e o $\log _{10}$ da razão foram obtidos para cada amostra (eixo Y). Para a construção da curva-padrão, o eixo X corresponde a valores fixos, previamente calculados, baseados nas diluições das amostras de DNA genômico controle (Tabela 2). 
Tabela 2. Cálculo da diluição das amostras controle utilizadas na curva-padrão para os ensaios de análise de expressão alelo-específica.

\begin{tabular}{ccc}
\hline Diluições & Razão & $\begin{array}{c}\text { Log10 da razão FAM/VIC } \\
\text { - Eixo X }\end{array}$ \\
\hline FAM VIC 4:1 & 4 & 0,60 \\
FAM VIC 3:1 & 3 & 0,50 \\
FAM VIC 2:1 & 2 & 0,30 \\
FAM VIC 1:1 & 1 & 0,00 \\
FAM VIC 1:2 & 0,5 & $-0,30$ \\
FAM VIC 1:3 & 0,33 & $-0,50$ \\
FAM VIC 1:4 & 0,25 & $-0,30$ \\
\hline
\end{tabular}

O eixo Y da curva-padrão corresponde à intensidade de $\log _{10}$ da razão FAM/VIC obtidas dos valores de intensidade de fluorescência a partir das diluições. Em planilha, os dados dos eixos X e Y foram selecionados e um gráfico de dispersão foi construído. No gráfico, a fórmula de equação da reta e o R-quadrado foram incluídos. Depois de construída a curva-padrão, (para identificar a expressão alelo-específica de cada amostra), o cálculo da razão FAM/VIC foi obtido.

Para tal, a equação da reta obtida através da curva padrão foi usada para descobrir os valores no eixo $\mathrm{X}$, uma vez que os valores de $\log _{10}$ da razão correspondem ao eixo Y (obtidos a partir do ensaio de Taqman). Em seguida, a razão FAM/VIC foi revelada através do calculo do exponencial na base 10 com o valor do eixo X. Se os resultados forem positivos, o valor da razão FAM/VIC já está determinado, se os resultados forem negativos, calcular 1/exponencial na base 10 para calcular a razão FAM/VIC. 


\subsection{Análise estatística}

As análises gráficas foram realizadas usando-se o software Graph Pad 4 (GraphPad, San Diego, CA, USA). Para se avaliar a possível diferença estatística entre os experimentos realizados, foram-se usados os testes de One-way ANOVA e Two-way ANOVA, de acordo com o tipo de experimento feito. 


\section{RESULTADOS}

\subsection{Papel de p53 na resposta a UVB}

\subsubsection{Sensibilidade à exposição à UVB em linhagens de melanomas}

O papel da radiação UVB no desenvolvimento de melanomas já tem sido descrito na literatura, inclusive sendo esta relação já descrita por estudos do grupo (Gonçalves et al., 2011). Para procurar entender melhor as vias moleculares envolvidas neste processo, procurou-se testar inicialmente em duas linhagens de melanoma os mecanismos de respostas à UVB. As linhagens Skmel-28 e Skmel-37, duas linhagens que segundo a literatura apresentam diferenças quanto à funcionalidade de p53 (http://p53.fr), foram inicialmente usadas e expostas a três doses iniciais de UVB (60, 120 e $240 \mathrm{~J} / \mathrm{m}^{2}$ ) e o padrão de morte celular foi observado após os tempos de 24 e $48 \mathrm{~h}$ após irradiação. Os resultados (Figura 4) demonstram que a linhagem Skmel-38 apresentou maior sensibilidade à UVB, sendo inclusive a sensibilidade maior após 48h.

Para confirmar a maior sensibilidade de Skmel-28, ensaios de sobrevivência por formação de colônias também foram realizados. Neste caso, a mesma quantidade de células para Skmel-28 e Skmel-37 foram plaqueadas e posteriormente irradiadas com diferentes doses de UVB. A sensibilidade das linhagens foi medida pela porcentagem de colônias em relação ao controle (Figura 4C) e demonstrou que, corroborando com os ensaios de morte celular, Skmel-28 apresenta maior sensibilidade à UVB. Para os demais ensaios referentes às respostas à UVB, optou-se por usar a dose de $120 \mathrm{~J} / \mathrm{m}^{2}$, a qual mostrou importante diferença entre as linhagens quanto a sensibilidade, sendo, no entanto, não tão letal quanto doses maiores. 
A
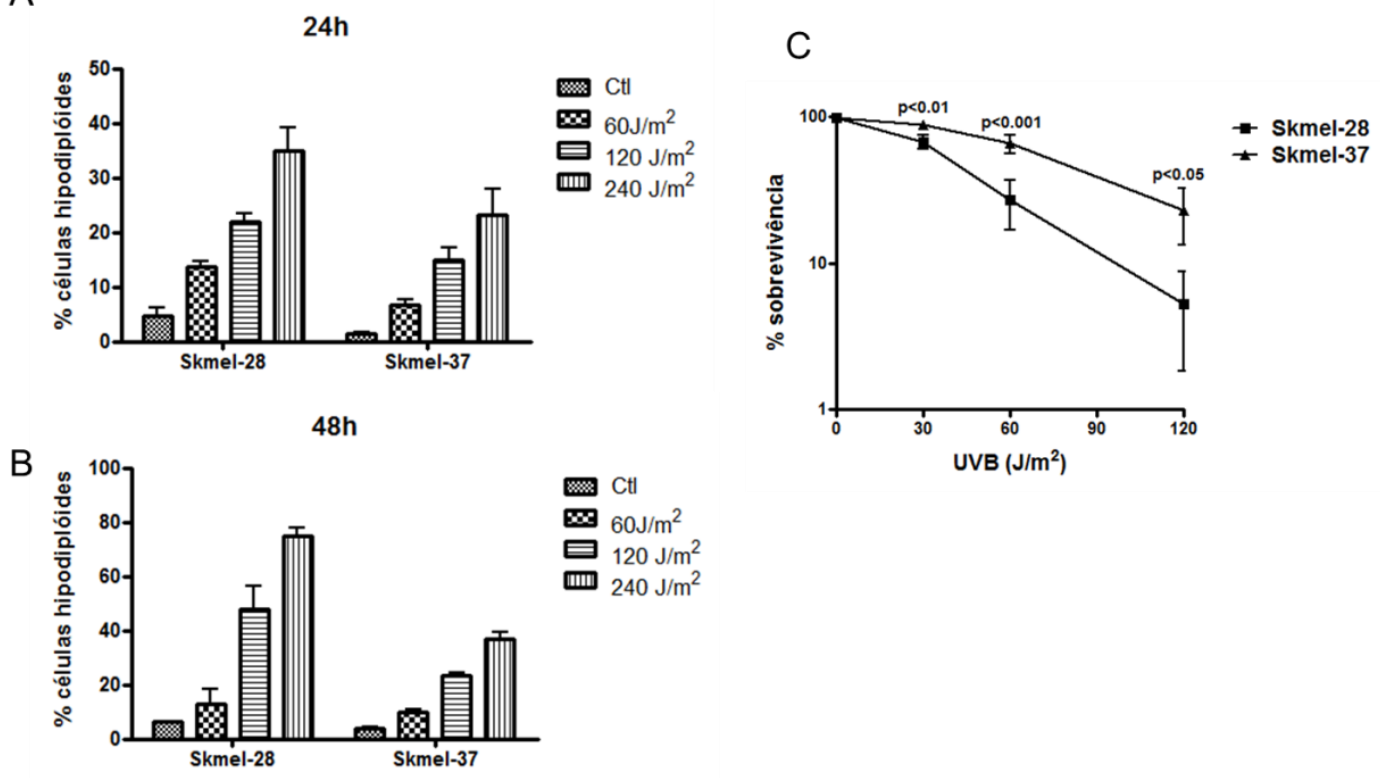

Figura 4. Sensibilidade das linhagens Skmel-28 e Skmel-37 à UVB. (A) Morte celular após 24h. (B) Morte celular após 48h. (C) Ensaios de sobrevivência por formação de colônias. Resultados mostram média e desvio padrão de ensaio em triplicata. Ensaio representativo de triplicatas independentes.

Como melanomas tem origem de melanócitos, células pigmentadas cuja função da melanina é proteger o DNA dos efeitos nocivos da radiação UVB, verificou-se se existiria quantidade de melanina diferente entre as duas linhagens que pudesse mascarar a sensibilidade apresentada. A quantidade de melanina foi avaliada, tendo-se como referência a quantidade de melanina apresentada pela linhagem Skmel-188 (a qual apresentava pigmentação visível in vitro). A medida da quantidade de melanina não demonstrou grande diferença entre as linhagens. Os valores obtidos para a leitura de melanina em 400 e $470 \mathrm{~nm}$ pode ser vista no Anexo A.

4.1.2 Expressão de proteínas da via NER, ensaio de recuperação de RNA e de reparo de DNA

Visto a maior sensibilidade de Skmel-28 à UVB e tendo em mente a estreita relação entre os danos causados por UVB e o reparo via NER, procurou-se analisar a 
expressão de importantes proteínas desta via de reparo de DNA em ambas as linhagens após a irradiação. A expressão de proteínas como XPC, XPV (também descrita como polimerase eta) e DDB-2 pode ser vista na figura 5. A análise da expressão destas proteínas permite concluir que sua expressão é menor em Skmel-28 em relação à Skmel-37, o que de certa forma poderia explicar sua maior sensibilidade.

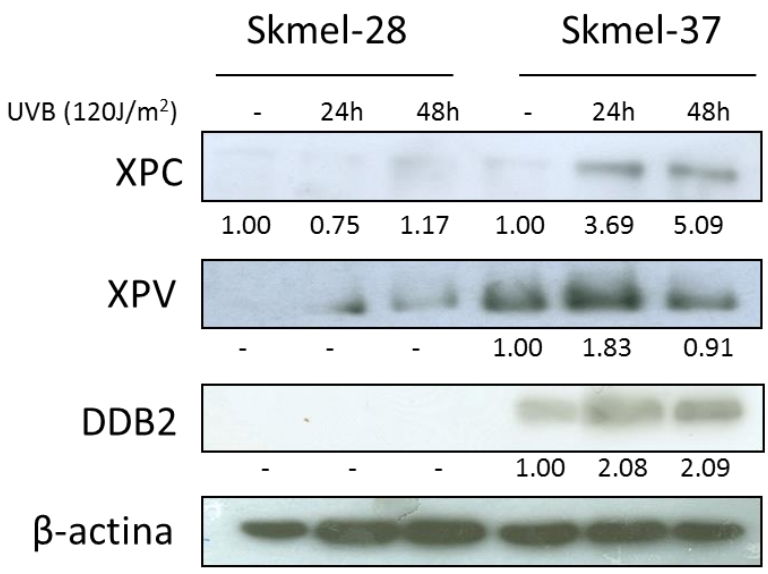

Figura 5. Western Blotting para XPC, XPV e DDB-2 em Skmel-28 e Skmel-37 após UVB.

No entanto, a maior sensibilidade poderia estar relacionada a uma não funcionalidade da via NER em decorrência de possíveis mutações em outros componentes da via. Para verificar a funcionalidade da via NER, pelo menos no que consistem os passos a seguir do reconhecimento, onde atuam XPC e DDB-2 (Figura 2), nos verificamos a capacidade de recuperação de RNA das duas linhagens. Este ensaio de recuperação permite uma inferência indireta da funcionalidade de NER através da atividade da sub-via TCR-NER, a qual atua justamente no reparo de lesões em regiões transcritas. Desta maneira, as duas linhagens foram irradiadas com duas doses de UVC (espectro escolhido devido ao protocolo já estabelecido e também devido ao fato de UVC realizar apenas danos diretos ao DNA, ao contrário de UVB e UVA que podem 
criar espécies reativas de oxigênio) sendo a quantidade de RNA total mensurada. Como controle utilizou-se uma linhagem celular oriunda de paciente com síndrome de Cockayne, a qual apresenta mutação no gene $C S B$ e, portanto mau funcionamento da via TCR-NER (Figura 2).

Os resultados obtidos a partir do ensaio de recuperação de RNA demonstraram que as duas linhagens apresentam a mesma capacidade de recuperação de RNA após os tempos analisados e também para as duas doses testadas (Figura 6). Ambas as linhagens apresentaram de recuperação superior à linhagem CSB, usada como controle. Desta maneira, os resultados sugerem que a sensibilidade pode estar relacionada à baixa expressão de genes de reparo que atuem no reconhecimento de lesões como XPC e DDB-2, além de XPV, que possui importante função na correção de lesões por UV em dímeros de timina durante a replicação.

A

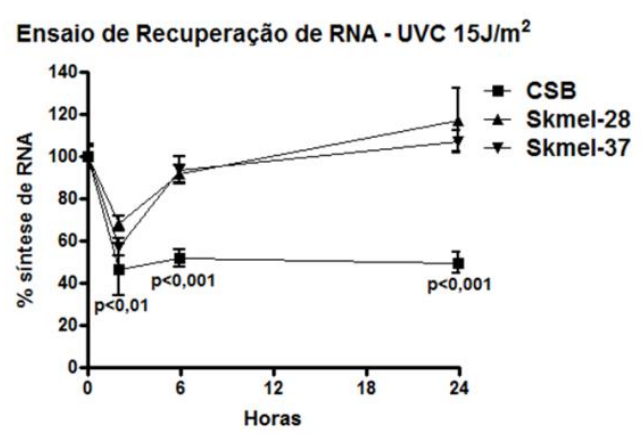

B

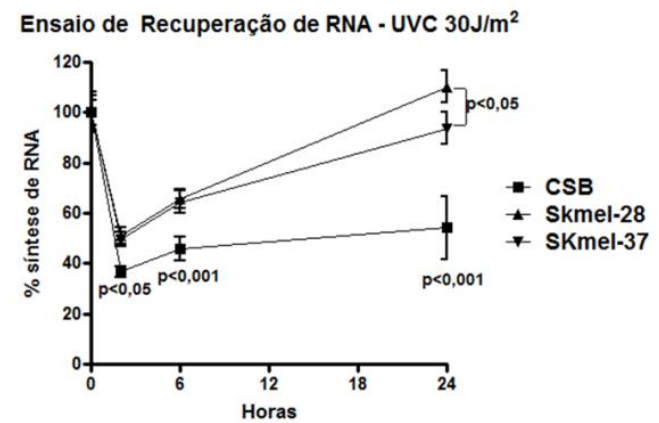

Figura 6. Ensaio de Recuperação de RNA nas linhagens Skmel-28, Skmel-37 e CSB. (A) $15 \mathrm{~J} / \mathrm{m}^{2}$ (B) 30 $\mathrm{J} / \mathrm{m}^{2}$. Resultados mostram média e desvio padrão de ensaio em triplicata.

Com o cenário desenhado pelos resultados, onde a baixa expressão de alguns genes da via NER e as evidências do funcionamento da via TCR-NER, a prévia observação da sensibilidade de Skmel-28 poderia ser em decorrência de menor taxa ou mais tardio reparo de DNA de lesões causadas pela exposição à UVB. Para testar essa 
hipótese, as linhagens foram expostas à UVB por tempos determinados e o DNA extraído para análise da cinética de reparo de lesões do tipo CPD.

O resultado da análise da cinética de reparo demonstrou que de fato Skmel-28 possuia menor atividade de reparo de lesões UVB quando comparada a Skmel-37 (Figura 7), fato este que pode estar relacionado à baixa expressão de genes como XPC, DDB-2 e XPV, como visto anteriormente.
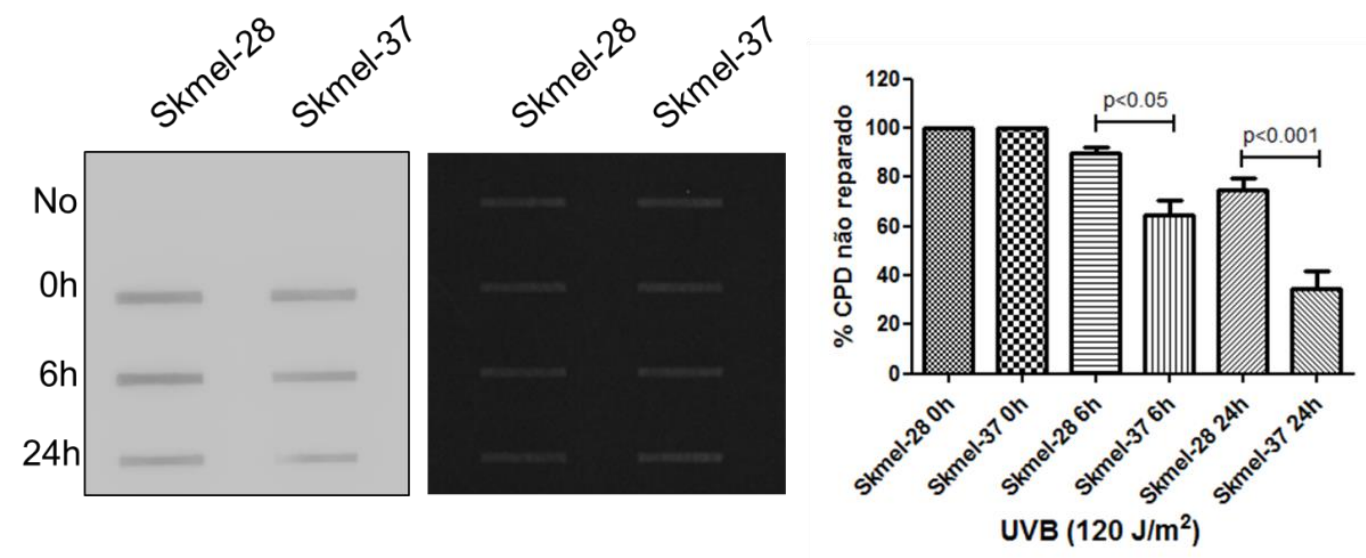

Figura 7. Dot-Blot para reparo de lesões do tipo CPD em Skmel-28 e Skmel-37. O gráfico mostra média e o erro padrão de três experimentos independentes.

Como o acúmulo de danos no DNA pode acarretar em quebras na fita de DNA, avaliou-se também a quantidade de danos do tipo fosfo-H2AX, cuja fosforilação neste grupo de histonas sinaliza para danos no DNA. Para tal avaliação as linhagens foram expostas a UVB e vistas sob microscopia confocal para visualização e contagem dos números de foci para fosfo-H2AX. As imagens da captura dos foci de fosfo-H2AX podem ser vistas no material em anexo B. Já a contagem dos números de foci foi plotada em gráfico e pode ser visto na figura 8. Nos gráficos apresentados, é possível verificar que a quantidade de número de foci maior que 5 (número arbitrário que consideramos como consequência de danos UVB não reparados) é maior em Skmel-28 
em comparação à Skmel-37. Após 24h este número de mostra significativo para número de foci de 6-10 e 11-15, enquanto que em 48h a principal diferença fica com o número de foci maior que 20 .
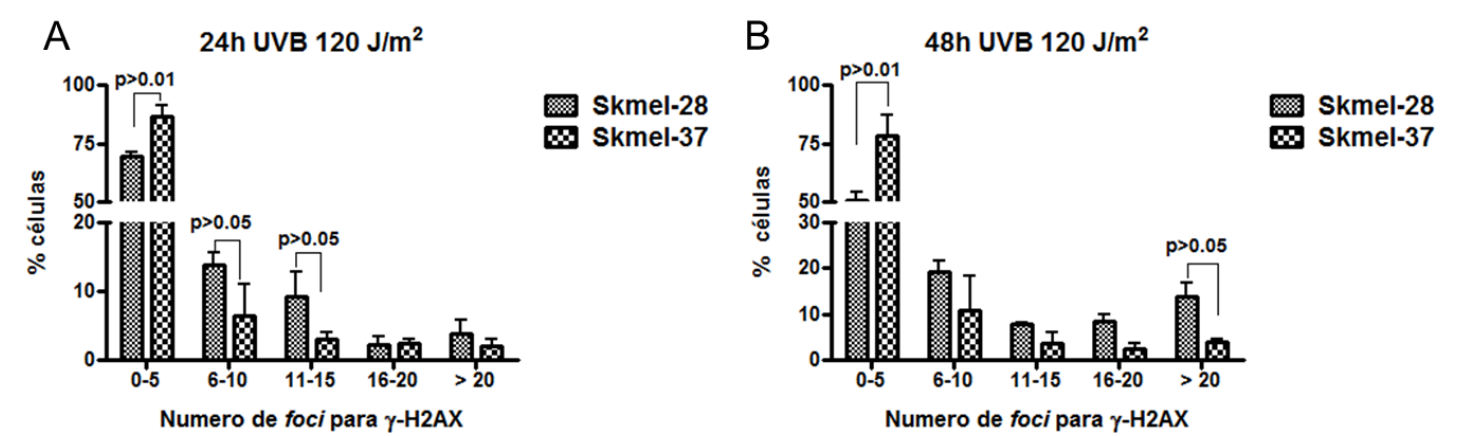

Figura 8. Contagem do número de foci para fosfo-H2AX em Skmel-28 e Skmel-37 após UVB. (A) Contagem após 24h. (B) Contagem após 48h. O gráfico mostra média e o erro padrão de três experimentos independentes.

\subsubsection{Papel de p53 na resposta à UVB em melanomas}

Como os dados anteriores sugerem que a baixa expressão de genes de reparo da via NER podem estar relacionados a maior sensibilidade de Skmel-28 devido justamente a menor cinética de reparo, os próximos passos adotados foram de tentar relacionar estes últimos resultados com alguma via upstream que pudesse estar relacionada a tais resultados. Inicialmente se procurou explorar duas importantes vias, a via de p53 e a via ERK. Análise destas vias por western blotting mostra que para a via p53, a própria proteína p53 se mostra ativa em Skmel-37 não só pela sua expressão mas também pela expressão de p21, gene normalmente ativado pela atividade de p53. Já em Skmel-28, a via demonstrou estar inativa. Já a análise dos níveis de ativação da via ERK, medidos pelo nível de fosforilação de ERK1, demonstrou que em ambas as linhagens não houve diferença com a exposição à UVB (Figura 9). 


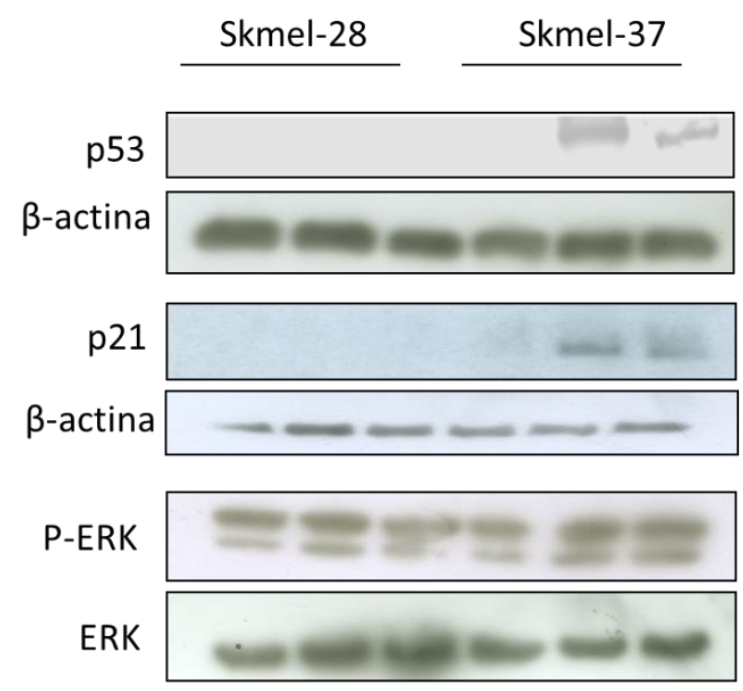

Figura 9. Western Blotting para p53, p21 e fosfo-ERK em Skmel-28 e Skmel-37 após exposição à UVB.

Com os resultados sugerindo a participação de p53 nos resultados descritos, uma vez que p53 está relacionado a transcrição de diversos genes, incluindo genes de reparo, focou-se na participação de p53 na sensibilidade à UVB. Para testar o papel de p53, utilizou-se inicialmente o inibidor farmacológico pifithrin- $\alpha$ para abolir a atividade transcricional de p53. Com a utilização de pifithrin- $\alpha$ nas linhagens de melanoma, observou-se que enquanto em Skmel-28 não houve efeito no padrão de morte celular (o que pode ser explicado pela ausência de expressão de p53), em Skmel-37 o uso do inibidor aumentou a sensibilidade da linhagem à UVB, confirmando um papel importante de p53. Tomando em conta os resultados, é possível sugerir que a inibição de p53 por pifithrin- $\alpha$, leva a diminuição da atividade transcricional de p53, incluindo aí os genes de reparo como XPC e DDB-2, culminando com menor atividade de reparo e consequente maior sensibilidade. Os resultados podem ser visto na figura 10. 

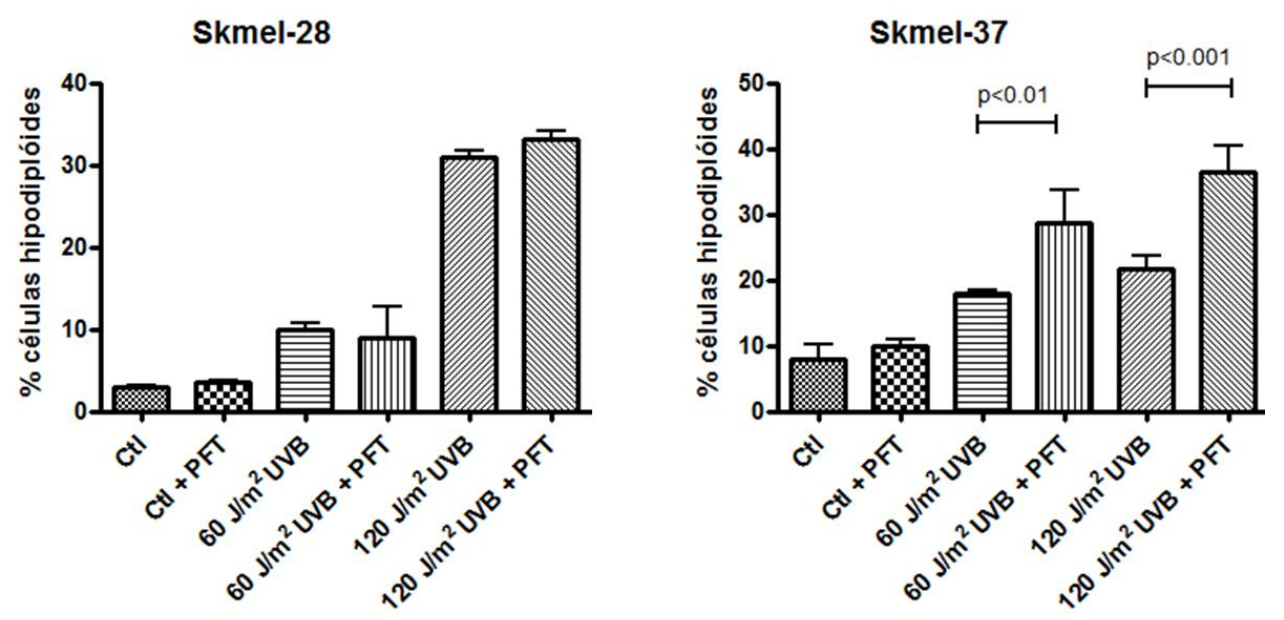

Figura 10. Morte celular em Skmel-28 e Skmel-37 após 48h de exposição à UVB e uso de pifithrin- $\alpha$. Resultados mostram média e desvio padrão de ensaio em triplicata. Ensaio representativo de triplicatas independentes.

Com os resultados para pifithrin- $\alpha$ indicando o papel de p53 o passo a seguir foi tentar restaurar a atividade p53 em Skmel-28. A ideia em questão era restaurar a atividade da via e confirmar seu papel na resposta à UVB em melanomas. Para tal, utilizou-se de vetores virais contendo construção para expressão de p53, sendo este controlado por promotor responsivo a p53 (Strauss \& Costanzi-Strauss, 2004). Uma vez com esta linhagem, junto com seu respectivo controle, foi-se repetido o ensaio de morte celular para averiguação do papel de p53. Os resultados demonstraram que a reexpressão de p53 em Skmel-28 levou a linhagem a apresentar menor sensibilidade a UVB quando comparada a linhagem transfectada controle (Mock)(Figura 11). 


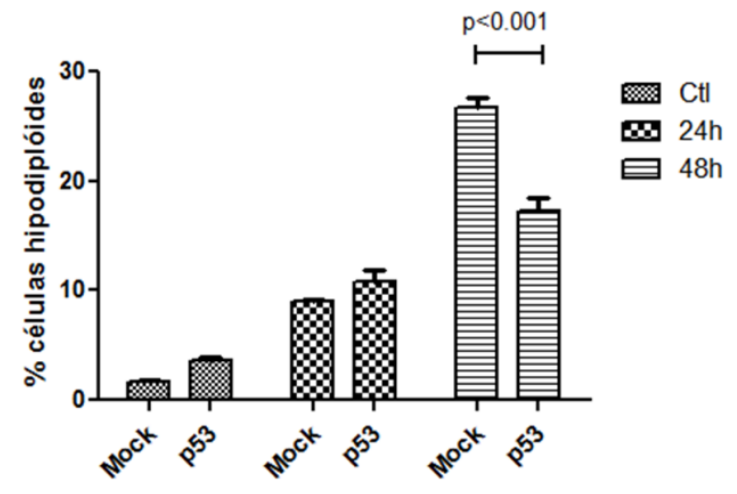

Figura 11. Morte Celular de Skmel-28 transfectada para expressar p53 e seu respectivo controle (Mock) após 48h de exposição à UVB. Resultados mostram média e desvio padrão de ensaio em triplicata. Ensaio representativo de triplicatas independentes.

Com o resultado confirmando a participação de p53 na sensibilidade à UVB, neste caso em específico levando a menor taxa de morte celular, verificou-se se a expressão de proteínas de reparo foi influenciada pela re-expressão de p53 e consequentemente se houve diferença na cinética de reparo com esta nova condição de expressão em Skmel-28. A expressão de XPC, XPV e p53 foi avaliada por western blotting e o resultado pode ser visto na figura 12. Pode-se notar que a re-expressão de p53 em Skmel-28 aumentou a expressão destas duas proteínas, o que confirma o papel de p53 na expressão destas proteínas.

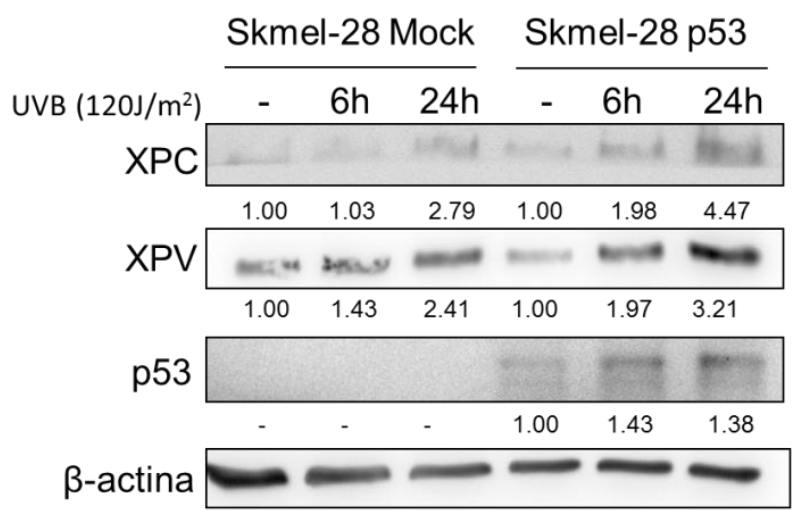

Figura 12. Western Blotting para XPC, XPV e p53 em Skmel-28 transfectada com vetor para expressão de p53 e seu controle (Mock). 
Com o aumento da expressão de XPC e XPV verificou-se se a re-expressão de p53 alteraria a cinética de reparo de lesões CPD. A análise feita a partir do ensaio de dot-blot sugeriu que este aumento de expressão das proteínas de reparo XPC e XPV contribuiu para a diminuição da quantidade de lesões do tipo CPD após 24h, demonstrando assim a importância de p53 não só no aumento da expressão destas proteínas de reparo como também na sensibilidade à UVB (Figura 13).
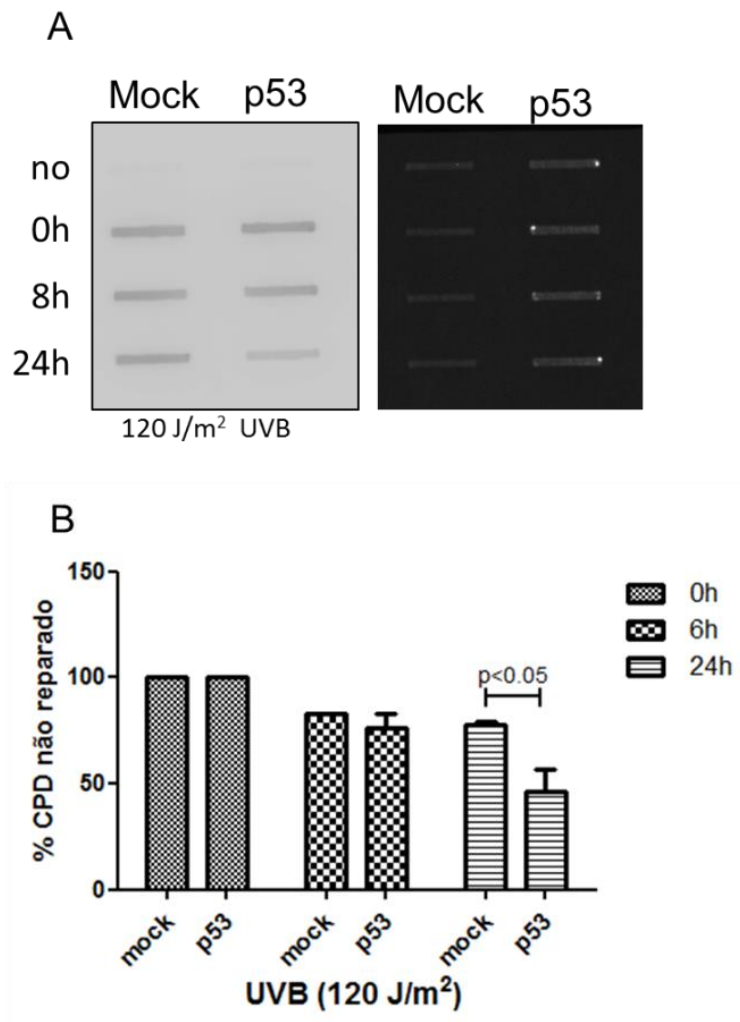

Figura 13. Cinética de reparo de lesões CPD em linhagem Skmel-28 transfectada com vetor viral para expressão de p53 e controle (Mock). (A) Dot-blot para lesões do tipo CPD após os tempos determinados. (B) Gráfico demonstrando média e erro padrão de duplicatas independentes para a cinética de reparo de lesões CPD.

\subsubsection{Vias de Morte Celular em melanomas após UVB}

Com o intuito de continuar a explorar as respostas das duas linhagens de melanoma à UVB, focou-se agora nas respostas referentes a ativação de morte celular. 
Como os resultados anteriores demonstraram que a via de p53 está relacionada ao padrão diferenciado de morte entre ambas as linhagens, verificou-se se havia também diferenças quanto a ativação de vias de morte celular. Os resultados para a expressão de proteínas envolvidas com vias de morte como PUMA $\alpha / \beta$, BAD e BCL-2 podem ser vistas na figura 14.

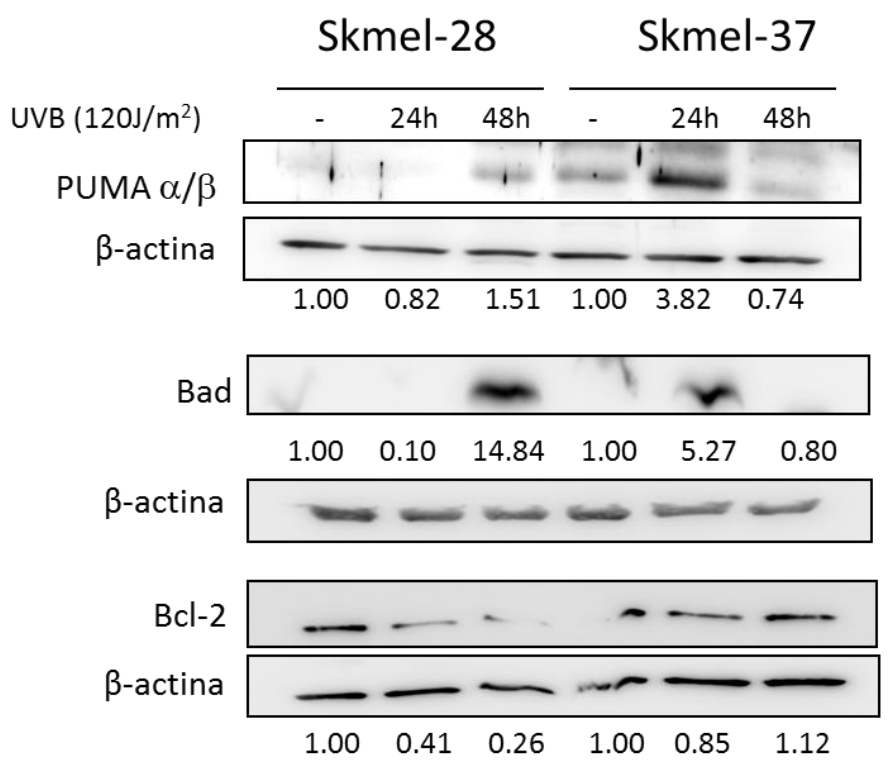

Figura 14. Western blotting para expressão de PUMA $\alpha / \beta$, BAD e BCL-2 em Skmel-28 e Skmel-37 após UVB.

Os resultados mostram que a expressão de proteínas pró-apoptóticas como PUMA $\alpha / \beta$ e BAD tem sua expressão maior após $24 \mathrm{~h}$ de UVB em Skmel-37 seguida por queda desta expressão em 48h. Ao contrário, em Skmel-28 a expressão destas proteínas pró-apoptóticas tem sua maior expressão após $48 \mathrm{~h}$ da exposição à UVB. Já com relação a expressão da proteína anti-apoptótica BCL-2, sua expressão é diminuída conforme o tempo de exposição em Skmel-28 enquanto que em Skmel-37, após 24h se verificou pequeno aumento seguido de aumento de expressão após as $48 \mathrm{~h}$. 
Como a expressão destas proteínas esta relacionada a passos upstream no desencadeamento do processo de morte celular, o passo seguinte foi verificar a ativação de passos mais downstream, como a ativação de enzimas Caspases, as quais estão relacionadas a ativação do processo de morte celular por apoptose. Para tal caracterização verificou-se a ativação das Caspases efetoras de morte celular, as Caspases 3/7, cuja ativação pode ser verificada por fluoróforos específicos. A partir da análise por FACS para a ativação de Caspase $3 / 7$ mostrou-se que em ambas as linhagens houve ativação maior após 48h da exposição à UVB (Figura 15). No entanto, os resultados permitem verificar que a ativação foi maior em Skmel-28, o que pode ser confirmado pelo maior deslocamento à direita da fluorescência emitida e também pela análise por dot plot, realizada diretamente no FACS (Anexo C), onde se pode verificar a posição de cada evento adquirido em FL-1 (filtro utilizado para aquisição da fluorescência emitida pelo kit de detecção de ativação Caspase).
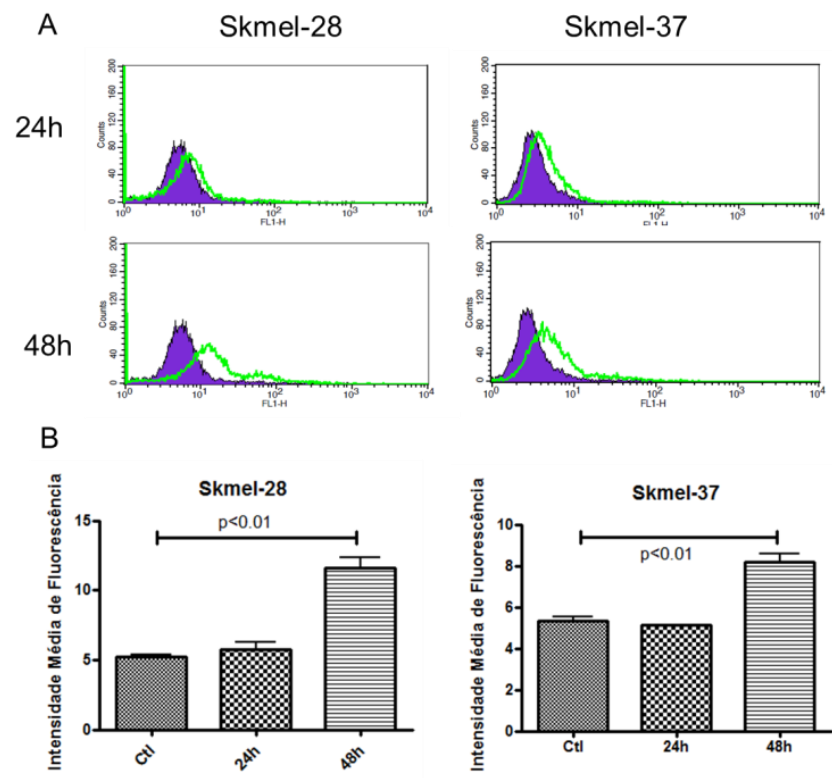

Figura 15. Ensaios de ativação de Caspase 3/7 após exposição à UVB $\left(120 \mathrm{~J} / \mathrm{m}^{2}\right)$ em Skmel-28 e Skmel37. (A) Histograma para o deslocamento da fluorescência para ativação de Caspase $3 / 7$ em relação ao controle. (B) Gráfico com a análise da intensidade média de fluorescência do ensaio de ativação de 
Caspase 3/7 nas linhagens de melanoma utilizadas. Resultados mostram média e desvio padrão de ensaio em duplicata. Ensaio representativo de triplicatas independentes.

Por fim, com o intuito de continuar a caracterização dos processos de morte celular disparados por exposição à UVB em melanomas, verificou-se se a atividade diferencial de p53 que as linhagens apresentam poderia influenciar no processo de autofagia, outro tipo de atividade celular que pode desencadear morte celular. O papel de p53 na atividade autofágica de células tumorais foi revisado por Sui e colaboradores (Sui et al., 2011). Duas proteínas são usadas como hallmarks do processo autofágico: Beclin-1 e LC-3. Beclin-1 está relacionado aos passos iniciais enquanto LC-3 está mais relacionado a fases mais tardias do processo, onde é clivado originando uma subunidade menor. Os resultados da expressão de ambas as proteínas pode ser visto na figura 16 e demonstraram que não houve aumento importante na expressão de Beclin-1 ou então na clivagem de LC-3, sugerindo que o processo autofágico não se demonstrou relevante no processo de morte celular em melanoma após UVB, independentemente do status funcional de p53 nas linhagens analisadas.

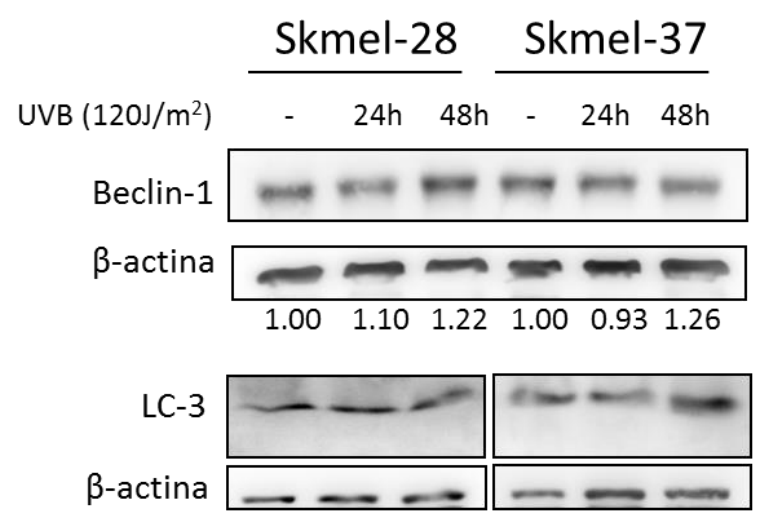

Figura 16. Western Blotting para Beclin-1 e LC-3 após UVB em Skmel-28 e Skmel-37.

4.1.5 Produção de Espécies Reativas de Oxigênio (ROS) e sua relevância no processo de morte celular após $U V B$ 
Além da lesão direta que a exposição à UVB pode acarretar no DNA, como os CPDs e lesões 6-4 PP, é sabido que tal exposição também pode levar a produção de espécies reativas de oxigênio (Sander et al., 2004), as quais também podem contribuir para a aquisição de mutações e acarretar morte celular, embora em um percentual baixo em comparação com as lesões diretas. Para verificar se a exposição à UVB também contribuiria para a produção de ROS, as linhagens foram expostas e a produção de ROS foi mensurada por FACS utilizando-se o fluoróforo DHR (di-hidro-rhodamina 123, o qual ao ser oxidado por tais moléculas emite fluorescência), após 24 e 48h. A análise demonstrou que a produção de ROS teve maior pico de produção após as $48 \mathrm{~h}$ de exposição, tanto em Skmel-28 quanto em Skmel-37. O deslocamento da fluorescência, no entanto, demonstrou ser maior em Skmel-28. O histograma de fluorescência e o gráfico obtido dos valores podem ser vistos na figura 17.
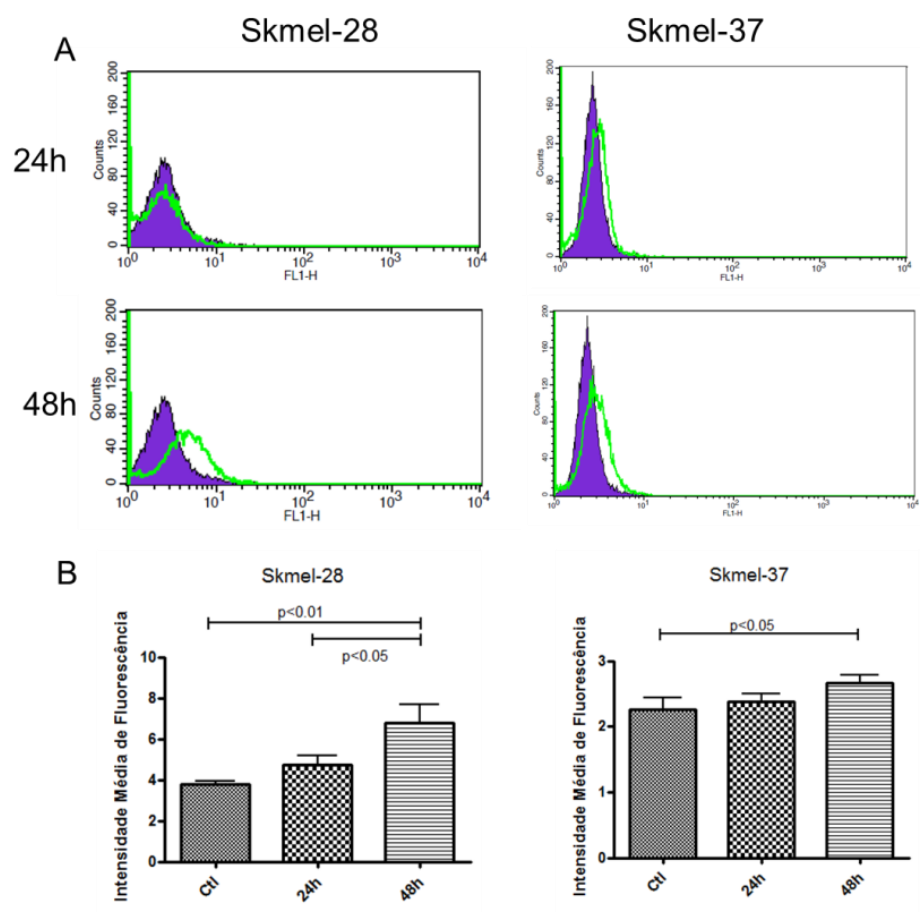
Figura 17. Ensaios de detecção de ROS após exposição à UVB (120 J/m²) em Skmel-28 e Skmel-37. (A) Histograma para o deslocamento da fluorescência para produção de ROS mensurada por DHR em relação ao controle. (B) Gráfico com a análise da intensidade média de fluorescência do ensaio de detecção de ROS nas linhagens de melanoma utilizadas. Resultados mostram média e desvio padrão de ensaio em triplicata. Ensaio representativo de triplicatas independentes.

Os resultados obtidos não só demonstraram que a exposição à UVB leva a produção de ROS mas também que a via p53 também pode estar envolvida uma vez que Skmel-28 apresentou maior deslocamento de fluorescência. Para averiguar se realmente existia tal relação, recorreu-se novamente a linhagem Skmel-28 transduzidas para expressão de p53 e seu respectivo controle Mock, sendo o ensaio para detecção de ROS por uso de DHR realizado novamente. A análise que pode ser vista na figura 18 , sugere realmente que a via de p53 pode estar relacionada também no processo de scavenger de espécies reativas. Nos histogramas respectivos quanto a produção de ROS, pode se observar que o deslocamento da fluorescência na linhagem Skmel-28 Mock é maior em relação ao controle quando comparada com o padrão de fluorescência exibida por Skmel-28 transduzida para expressão de p53.
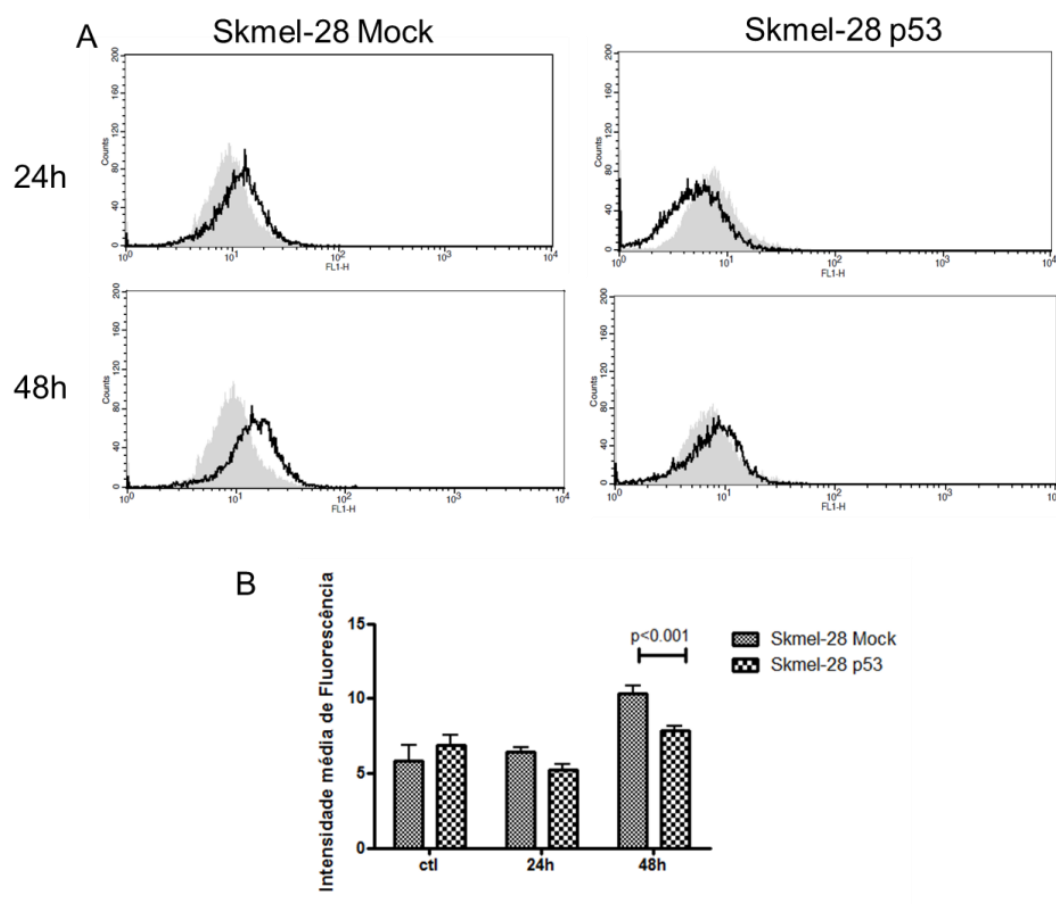
Figura 18. Ensaios de detecção de ROS após exposição à UVB (120 J/m²) em Skmel-28 transduzida. (A) Histograma para o deslocamento da fluorescência para produção de ROS mensurada por DHR em relação ao controle. (B) Gráfico com a análise da intensidade média de fluorescência do ensaio de detecção de ROS nas linhagens de melanoma utilizadas. Resultados mostram média e desvio padrão de ensaio em triplicata. Ensaio representativo de duplicatas independentes.

Por fim, buscou-se analisar se a quantidade de ROS produzida poderia de alguma maneira contribuir para o processo de morte celular observada após UVB. Para averiguar esta hipótese procurou-se tratar as células com substâncias capazes de fazer o scavenger de ROS, neste caso em específico Catalase (enzima responsável pela dismutação de peróxidos) e Tempol (substância capaz de dismutar ânions superóxidos). Inicialmente, para averiguar a funcionalidade destes compostos a linhagem Skmel-28 (a qual produz mais ROS após UVB) foi exposta à UVB e a produção de ROS foi medida novamente utilizando-se a metodologia já usada para DHR. A análise da produção de ROS ao se utilizar os dois compostos, demonstrou menor fluorescência, indicando assim sua funcionalidade (Anexo D). Uma vez testada a funcionalidade dos compostos acima citados, seus efeitos foram testados nas linhagens após UVB. Foram escolhidas duas concentrações de diferença de 10x para análise do efeito de cada concentração usada. Primeiramente para o efeito de Catalase, foi observado que em concentração menor (50 unidades), um efeito protetivo no intuito de menor taxa de morte pode ser observado em Skmel-37, enquanto em Skmel-28, embora não significativamente diferente, mostrou um indicativo de menor taxa de morte. Já para maior concentração, 500 unidades, tal efeito de dismutação de peróxidos levou a maior sensibilidade à UVB em ambas as linhagens. Para o uso de Tempol, o uso da menor concentração não levou a diferenças na sensibilidade à UVB, no entanto para a maior concentração houve aumento na taxa de morte em Skmel-37. Os resultados descritos podem ser observados na figura 19. Os resultados em geral demonstraram que Skmel-37 esteve mais 
susceptível aos efeitos da Catalase e do Tempol do que Skmel-28. De maneira contrária ao inicialmente esperado, maiores concentrações de Catalase ou Tempol aumentaram a sensibilidade à morte por UVB, o que sugere que de alguma forma as espécies reativas de oxigênio produzidas após UVB podem exercer um papel importante na ativação de vias de sobrevivência.

A

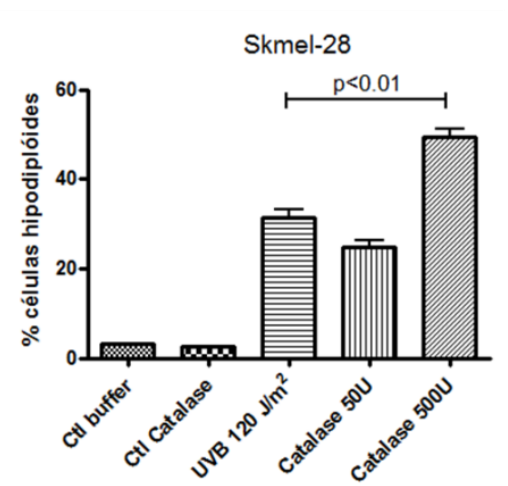

B

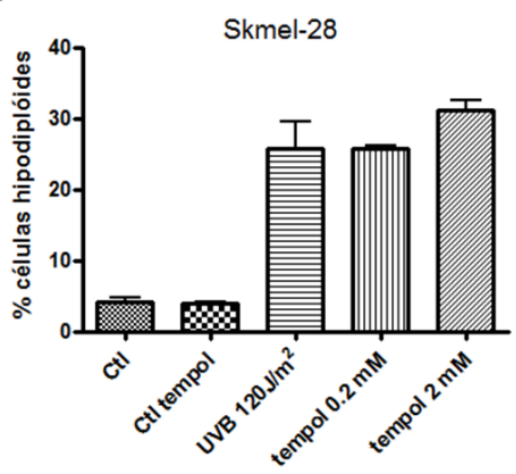

Skmel-37

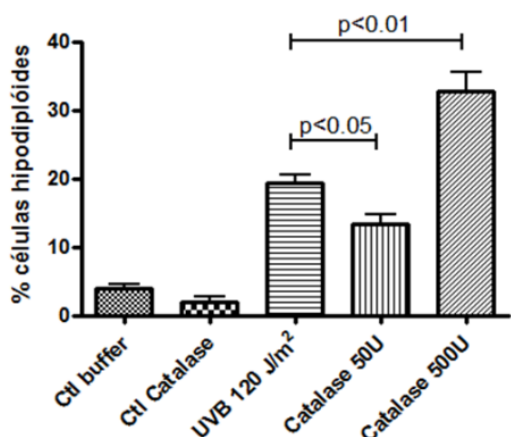

Skmel-37

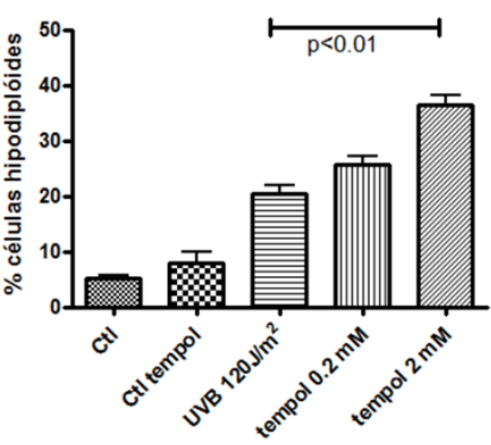

Figura 19. Análise de morte celular após UVB utilizando-se (A) Catalase e (B) Tempol. Resultados mostram média e desvio padrão de ensaio em triplicata. Ensaio representativo de triplicatas independentes. 


\subsection{Papel de hHR23B na biologia de melanomas}

4.2.1 Análise imunohistoquímica da expressão de hHR23B em amostras melanocíticas

Com o objetivo de analisar a influência do principal partner de XPC na biologia de melanomas, procurou-se inicialmente verificar o padrão de expressão de hHR23B em amostras de diferentes tecidos correspondentes a progressão de melanomas. Para tal, analisou-se sua expressão imunohistoquímica a partir de lâminas de tissue microarray (TMA). Este TMA foi composto de: 45 amostras de Nevus (lesões beningnas), 39 amostras de melanomas primários, 33 amostras de melanomas metastáticos localizados em linfonodos e 58 amostras de metástases viscerais de melanomas cutâneos. As amostras foram fotografadas e como análise comparativa foi contado a porcentagem de células positivas para marcação de hHR23B nuclear e citoplasmática. Imagens representativas das amostras melanocíticas a partir do TMA podem ser vistas nas figuras 20 e 21. 


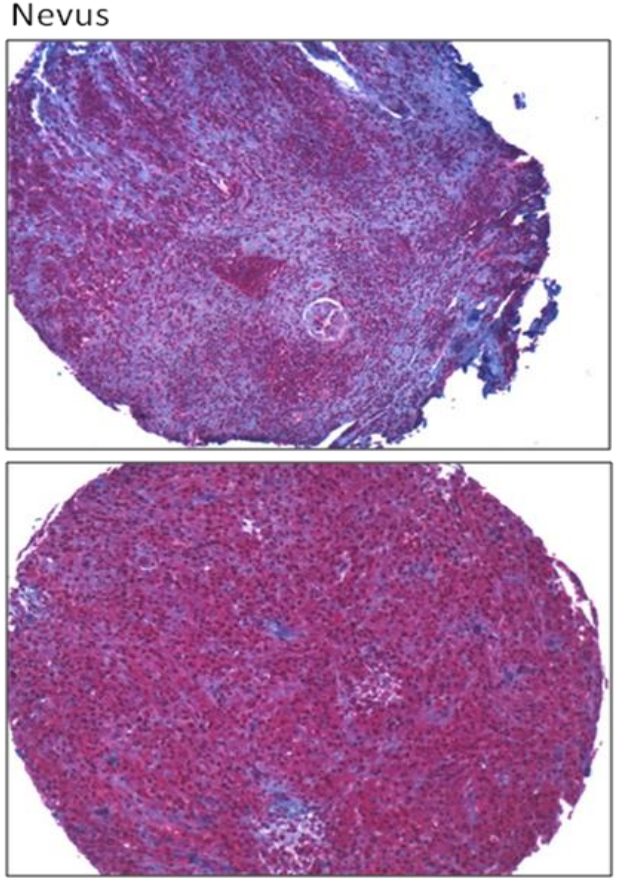

Linfonodo
TumorPrimário

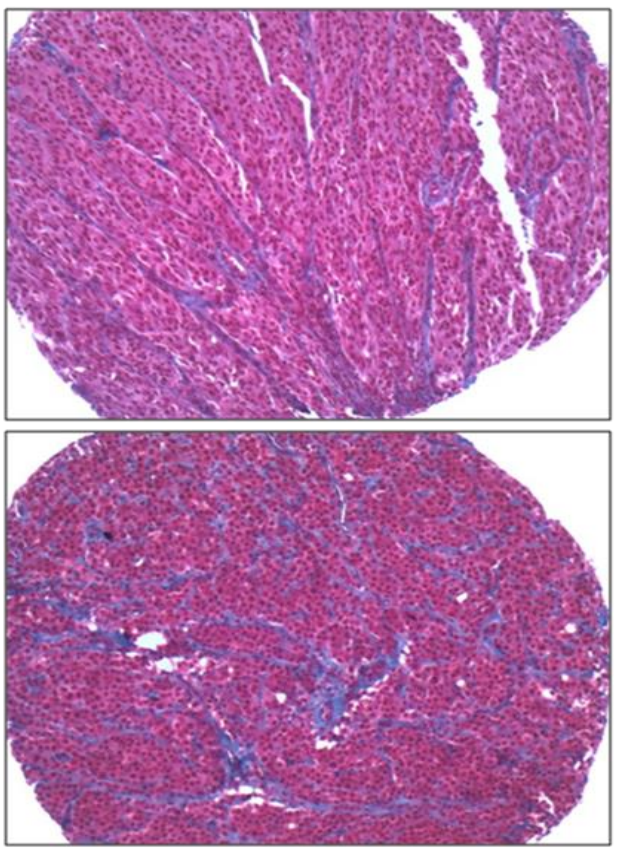

Metástase

Figura 20. Imagem representativa das lesões de origem melanocíticas analisadas por TMA. Na figura as imagens se apresentam com aumento de $5 \mathrm{X}$.
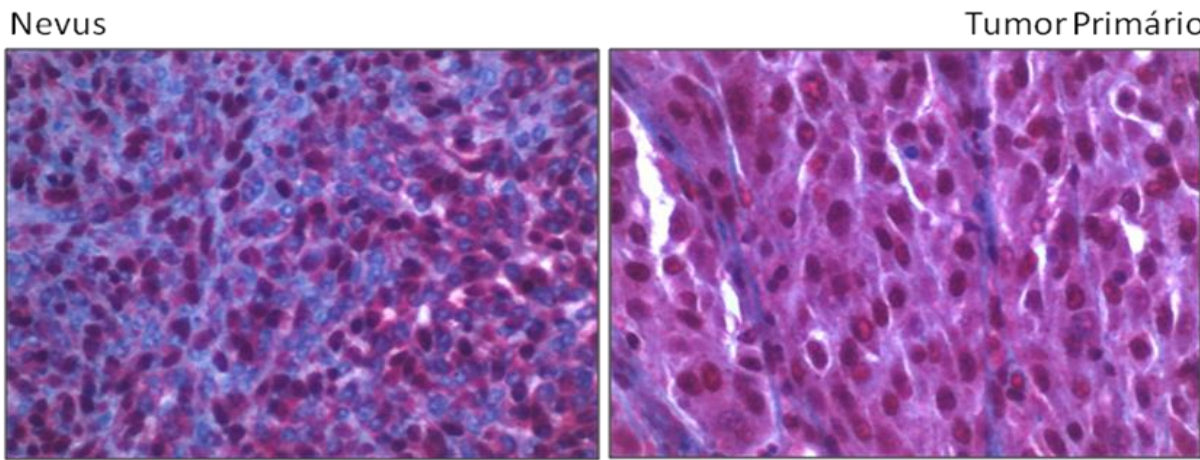

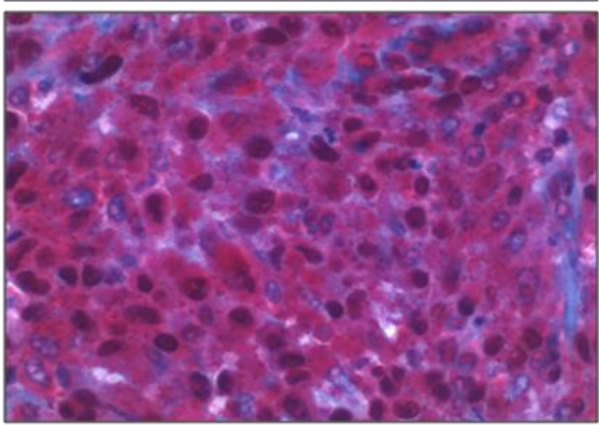

Linfonodo

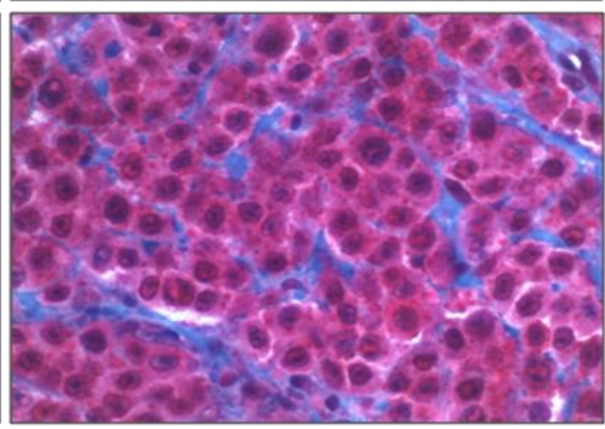

Metástase

Figura 21. Imagem representativa das lesões de origem melanocíticas analisadas por TMA. Na figura as imagens se apresentam com aumento de 20X. 
A análise imunohistoquímica mostrou que nas amostras de nevus há um importante heterogeneidade de marcação para hHR23B. Esta heterogeneidade demonstra que algumas células, mais precisamente alguns núcleos, não mostram marcação para hHR23B. Além disso, muitas células névicas também apresentam marcação citoplasmática para hHR23B. Já nas amostras de melanomas (primário, metástase linfonodal e metástase visceral) é possível verificar forte marcação para hHR23B, tanto nuclear quanto citoplasmático. Nestes casos, a heterogeneidade de marcação se mostra bem diminuída, onde nota-se prevalência de marcação de hHR23B na maioria das células que compõe a amostra.

Para que tal afirmação quanto à heterogeneidade de marcação tanto nuclear quanto citoplasmática fosse de certa forma mais mensurável, verificou-se a porcentagem de células positivas para a marcação com hHR23B nas amostras melanocíticas. O resultado pode ser observado na figura 22.
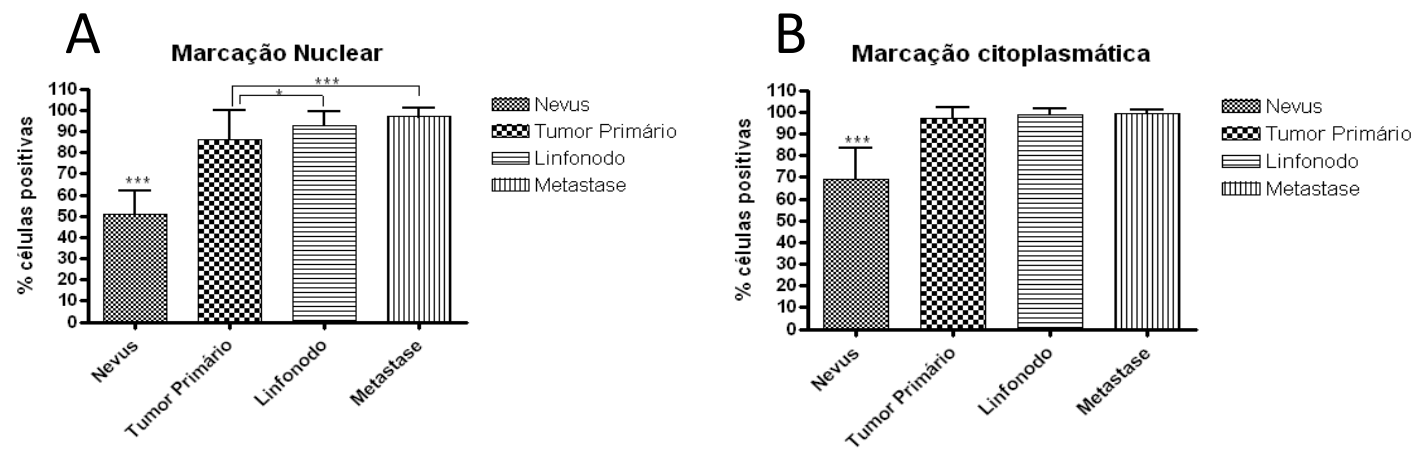

Figura 22. Análise da porcentagem de células positivas para hHR23B. (A) porcentagem de células positivas para marcação nuclear de hHR23B. (B) porcentagem de células positivas para marcação citoplasmática de hHR23B. * p <0.05, *** $\mathrm{p}<0.001$. Resultados mostram média e desvio padrão.

Os resultados da análise de positividade de marcação de hHR23B demonstrou que de fato as amostras de origem névica (Nevus) apresentavam menor porcentagem de 
células positivas para marcação de hHR23B, seja para marcação nuclear (Figura 22A), quanto para marcação citoplasmática (Figura 22B), fato este devido a heterogeneidade de marcação. Em ambos os casos, a porcentagem de células positivas para hHR23B foi estatisticamente diferente de todas as demais amostras melanocíticas analisadas. Outro dado que surgiu da análise foi também a diferença existente entre a marcação positiva nuclear de hHR23B nos tumores primários em comparação a ambas amostras metastáticas, seja linfonodal ou visceral, onde tal marcação se mostrou menor (Figura 22A).

Por fim, a análise de imunohistoquimica para hHR23B demonstra uma nova situação para a expressão desta proteína na biologia dos melanomas. Isto porque os resultados mostram que, diferentemente dos dados de linhagens de melanoma, nas amostras de tumores há uma grande expressão de hHR23B. Já nas amostras de lesões benignas (Nevus) existe uma considerável heterogeneidade de marcação. Além disso, os resultados chamam a atenção para a marcação citoplasmática de hHR23B, o que sugere outra função desta proteína além do reconhecido papel como participante dos primeiros passos da via GGR-NER, atuando em conjunto com XPC.

\subsubsection{Expressão de hHR23A e hHR23B em linhagens de melanoma}

Com os resultados obtidos a partir da análise de expressão de hHR23B, procurouse nas linhagens de melanoma existentes no laboratório expressão diferencial de hHR23B, a qual poderia servir de modelo para estudo da função desta proteína na biologia de melanomas. As linhagens já existentes no laboratório, Mel-85, LB373 e Skmel-37, foram testadas para a diferença de expressão entre hHR23A e hHR23B (Figura 23). O resultado demonstra claramente a diferença dos níveis de expressão de hHR23B em relação a hHR23A, principalmente nas linhagens Mel-85 e LB373, onde a expressão de 
hHR23B se mostra bem inferior a expressão de hHR23A. No entanto, na linhagem Skmel-37, a expressão gênica de hHR23B se mostra sutilmente maior que hHR23A.

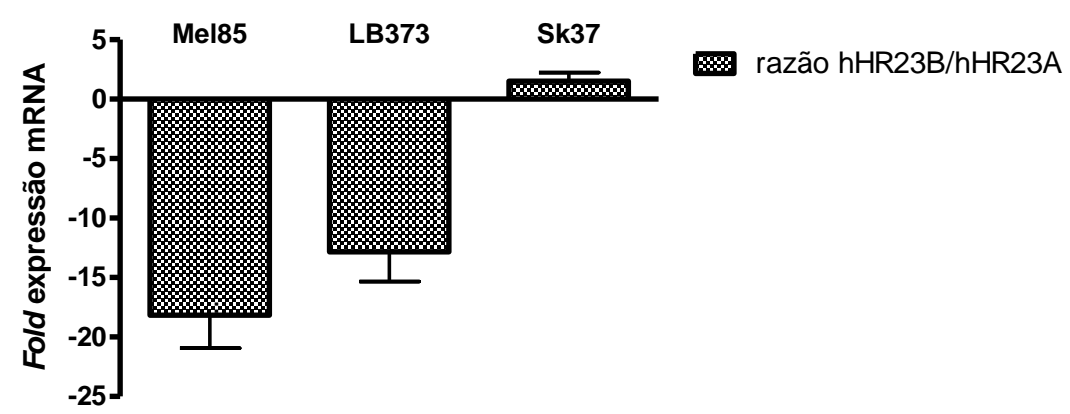

Figura 23. Resultado obtido por Real-Time PCR para avaliação da diferença de expressão entre hHR23A e hHR23B em linhagens de melanoma.

Uma vez que a análise por Real-Time PCR sugeriu um possível modelo para validação in vitro do papel de hHR23B, onde duas linhagens possuem baixa expressão de hHR23B e outra linhagem apresentava expressão detectável, o passo seguinte foi analisar a expressão das proteínas hHR23A e hHR23B nessas linhagens.

Como hHR23A e, principalmente, hHR23B estão inicialmente relacionadas ao reparo de lesões por ultravioleta, foi-se avaliado a expressão de ambas proteínas $6 \mathrm{~h}$ após estimulação por UVB em dose de $120 \mathrm{~J} / \mathrm{m}^{2}$, dose já demonstrada em experimentos anteriores do grupo para indução de genes relacionados a reparo de DNA. Como controle foi usado à expressão de Histona H3. A análise da expressão protéica das linhagens (Figura 24) demonstrou, confirmando os dados por Real-Time, a baixa expressão de hHR23B nas linhagens Mel85 e LB373, enquanto na linhagem Skmel-37 se manteve presente. Além disso, os resultados demonstraram que a expressão de hHR23A se manteve presente em todas as linhagens. Para ambas as proteínas hHR23A e hHR23B, a exposição a UVB não alterou sua expressão de maneira perceptível. 


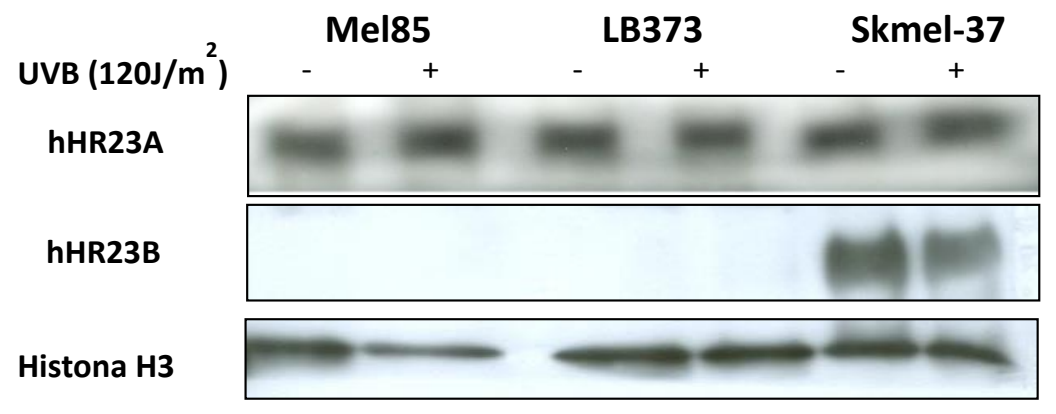

Figura 24. Expressão de hHR23A e hHR23B nas linhagens de melanoma.

Optou-se em seguida por analisar a expressão de hHR23B em outras linhagens de origem melanocítica diferentes, sejam humanas ou murinas. Para tal, nós analisamos a expressão nas linhagens NGM (melanócitos de origem primária), na linhagem SBCL2 (originada a partir de um melanoma de fase radial) e na linhagem WM905 (originada a partir de um melanoma metastático), gentilmente cedida pelo professor Meenhard Herlyn do Instituto Wistar (Philadelphia - USA). Quanto as linhagens murinas, foi utilizado as linhagens Melan-a (melanoma de crescimento radial), a linhagem TM1 (melanoma de crescimento vertical originado partir de Melan-a)(Oba-Shinjo et al., 2006), e a linhagem B16F10, de comportamento metastático. Em ambas as linhagens, humanas ou murinas, a expressão foi avaliada a partir de $6 \mathrm{~h}$ de irradiação com ultravioleta. $\mathrm{O}$ resultado pode ser observado na figura 25. 


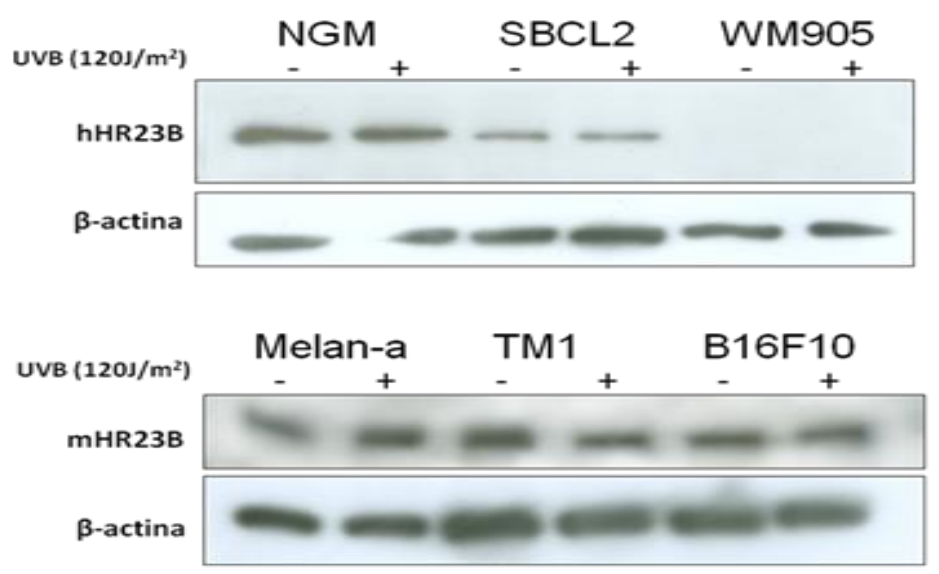

Figura 25. Expressão de hHR23B em linhagens de melanoma humanas e murinas, representativas de diferentes fases da progressão de melanoma.

Nas linhagens humanas, a expressão de hHR23B demonstrou inicialmente estar correlacionada ao comportamento biológico da lesão. Isto porque, há uma diminuição de hHR23B na linhagem de origem radial (SBCL2) quando comparada a linhagem de melanócitos (NGM), e também a perda da expressão de hHR23B nas linhagem de origem metastática (WM905). Contrariamente, nas linhagens de origem murina, não houve diferença da expressão de hHR23B, de acordo com o comportamento biológico da linhagem, evidenciando que a participação deste gene pode estar relacionada a um processo carcinogênico mais restrito a transformação de células humanas.

\subsubsection{Efeito do uso de 5'Aza- 2'-deoxicitidina na expressão de hHR23B}

Uma possibilidade da baixa expressão de hHR23B nas linhagens Mel85 e LB373 poderia ser através de metilação. Neste processo, grupos metil são adicionados à região promotora do gene em questão, mais especificamente em sítios CG (também conhecidos como ilhas $\mathrm{CpG}$ ). A adição destes grupos metil nestes sítios recruta diversas proteínas que acabam por compactar a cromatina, inabilitando o acesso de 
fatores de transcrição (em especial fatores SP1) e assim reprimindo a transcrição gênica (Deaton \& Bird, 2011).

Uma maneira de averiguar se a expressão de um gene está reprimida pode ser pela adição do composto 5'Aza- 2' -deoxicitidina, o qual age como um inibidor de proteínas DNA metil-transferases, responsáveis pela adição dos grupos metil nas regiões promotoras de genes. Desta maneira, através da inibição de DNA metiltransferases, genes previamente silenciados podem voltar a ser expressos.

Para averiguar a possibilidade de silencimento por metilação, as linhagens Mel85 e LB373 foram tratadas por $72 \mathrm{~h}$ com $10 \mu \mathrm{M}$ de 5'Aza- 2' -deoxicitidina, sendo o meio e o composto trocados a cada $24 \mathrm{~h}$. Após $72 \mathrm{~h}$, houve a extração de proteínas e posterior western blotting para hHR23B. Conforme pode ser observado na figura 26, houve um aumento da expressão de hHR23B em ambas linhagens após o tratamento com 5’Aza.

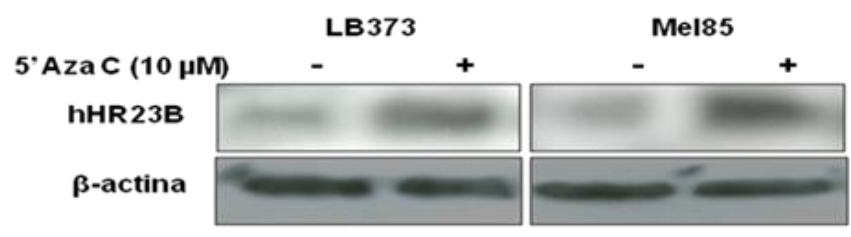

Figura 26. Expressão de hHR23B nas linhagens LB373 e Mel85 após tratamento com $10 \mu \mathrm{M}$ de 5’Aza2'-deoxicitidina.

Tal resultado sugere que a baixa expressão de hHR23B pode ser por processos de metilação do gene. A confirmação de um possível processo de metilação da região promotora deveria acontecer por seqüenciamento da região promotora e identificação de metilação nos sítios CpG. Embora tenha se tentado amplificar a região promotora de hHR23B nas linhagens, para posterior seqüenciamento, não se obteve sucesso em tal procedimento. 


\subsubsection{Ensaios de morte celular após irradiação com UVB}

Após verificar as linhagens de melanoma que apresentavam baixa expressão de hHR23B, testou-se se essa menor expressão poderia levar a maior sensibilidade a UVB. Desta maneira, as três linhagens de melanoma foram expostas a $120 \mathrm{~J} / \mathrm{m}^{2}$ de UVB e após $48 \mathrm{~h}$ verificadas para porcentagem de células hipodiplóides (aqui considerado como morte celular), por incorporação de iodeto de propídio (PI).

Os resultados de morte celular após UVB bem como histogramas representativos da análise citométrica de PI podem ser visto na figura 27. De maneira geral, os resultados indicam que as linhagens LB373 e Mel85 apresentavam maior sensibilidade à exposição UVB.

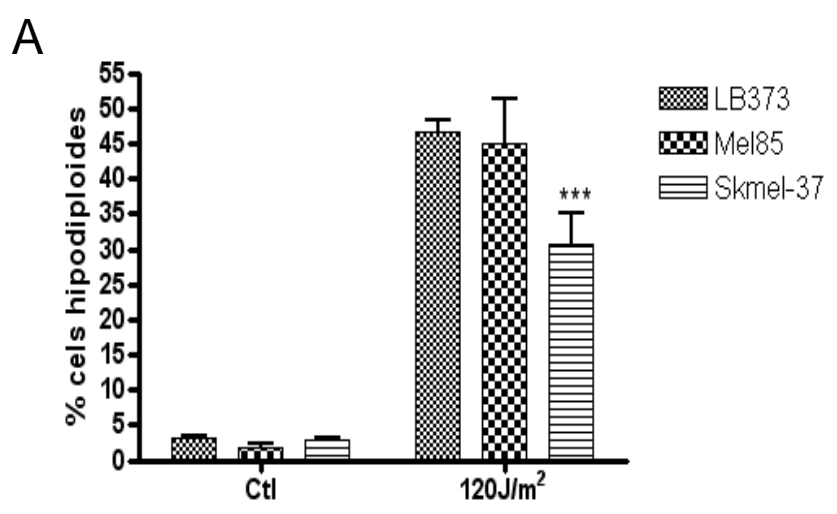


B Skmel-37
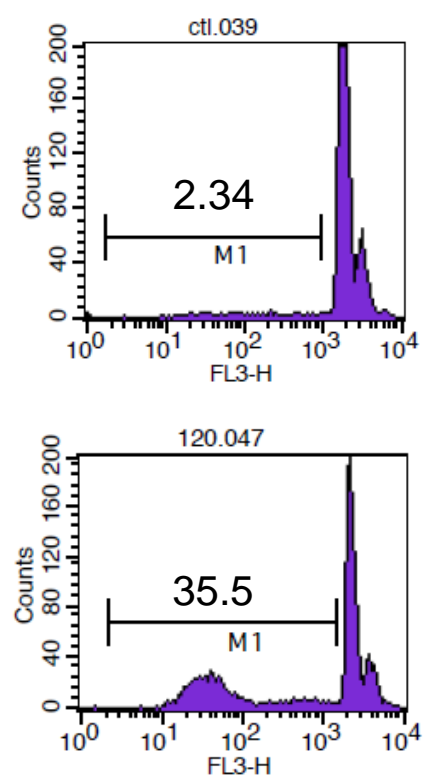

LB373
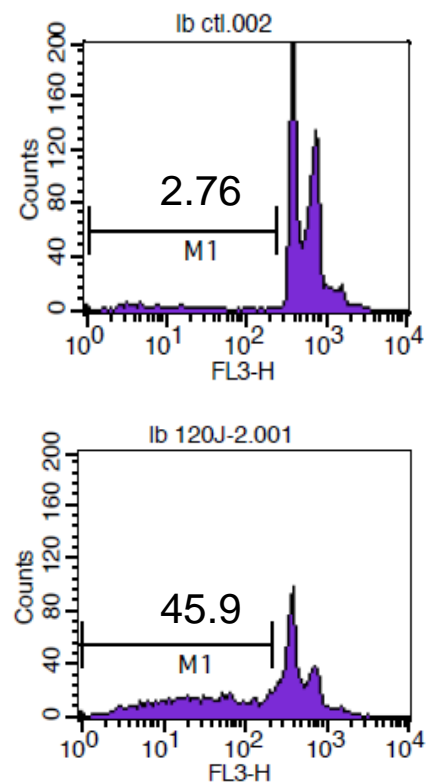

Mel85

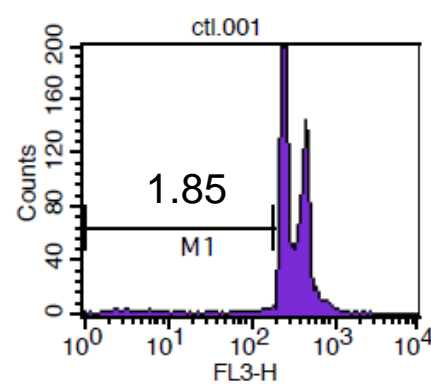

Ctl

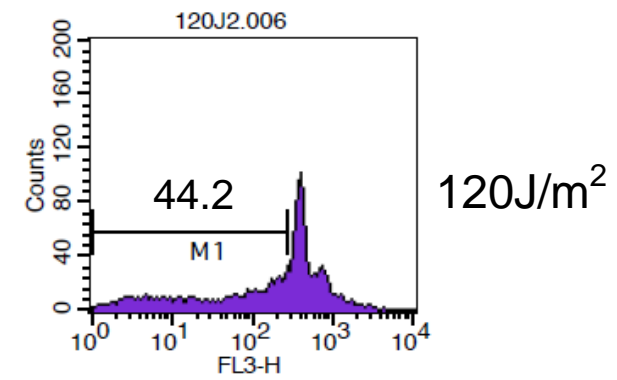

Figura 27. Morte celular após UVB. (A) \% de células hipodiplóides medida por incorporação de PI. (B) Histogramas representativos da análise citométrica. *** $\mathrm{p}<0.001$. Resultados mostram média e desvio padrão de ensaio em triplicata. Ensaio representativo de triplicatas independentes.

\subsubsection{Ensaios de Recuperação de RNA e Reparo de danos UVB}

Os resultados anteriores demonstravam que as células que possuem menor expressão de hHR23B, demonstravam maior sensibilidade a danos por UVB. Como hHR23B atua no primeiro passo da via NER (mais precisamente na via GGR-NER Figura 2), tal sensibilidade inicial das linhagens LB373 e Mel85, poderia estar relacionada também a um eventual mal-funcionamento dos passos posteriores do reparo de DNA, o que poderia produzir um resultado falso-positivo para a correlação de sensibilidade a UVB e expressão de hHR23B. Para testar a possibilidade que a sensibilidade a UVB está relacionada à baixa expressão de hHR23B e o correto funcionamento dos passos posteriores da via NER, foi-se realizado experimento para testar a capacidade de recuperação de RNA após UV.

Como a via NER atua em duas sub-vias (Figura 2), a via do TCR atua 
inicialmente na recuperação de lesões em fitas transcritas do DNA, operando via proteínas CSA e CSBs no reconhecimento de lesões que impedem a continuidade da RNA polimerase (Costa et al., 2003). Após o reconhecimento, os demais passos são comuns à via GG-NER. Assim, a recuperação de RNA após lesões UV, serve como indicativo da correta função dos passos iniciais do TCR-NER bem como o funcionamento de toda a via posterior ao reconhecimento, justamente onde hHR23B atua.

Assim, as linhagens Skmel-37, LB373 e Mel85 foram irradiadas com doses de 15 e $30 \mathrm{~J} / \mathrm{m}^{2}$ e UVC e a quantidade de RNA foi medida a partir dos tempos de 2,6 e 24h. A taxa de transcrição controle foi medida no tempo de 0h sem exposição à UVC Optou-se por usar UVC devido sua ação direta em só produzir danos tipo dímeros de pirimidina, uma vez que UVB pode levar a produção de espécies reativas de oxigênio, as quais também podem ocasionar lesões que sejam reparadas por TCR (Stevnsner et al., 2008). Como controle, foi-se usada a linhagem celular de fibroblastos mutados para CSB. Os gráficos presentes na figura 28 demonstram os resultados para a taxa de recuperação de RNA após UV.
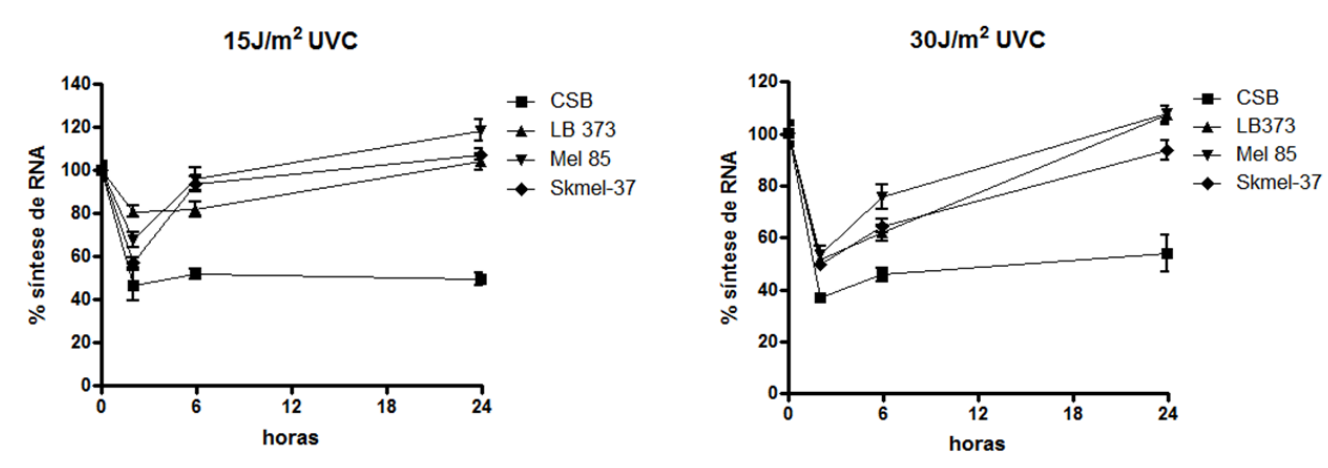

Figura 28. Ensaio de recuperação de RNA nas linhagens de melanoma e na linhagem CSB após irradiação com diferentes doses de UVC. Resultados mostram média e desvio padrão de ensaio em triplicata.

Os resultados obtidos demonstram a recuperação do processo de transcrição 
das linhagens de melanoma após $2 \mathrm{~h}$ de exposição à UVC, ao mesmo tempo em que demonstram a ineficiência das células CSB nesta recuperação. É possível observar que após $2 \mathrm{~h}$ de exposição, todas as linhagens apresentam um decréscimo da quantidade de RNA como consequência dos danos causados por UVC na transcrição. No entanto, é possível observar que após 6 h todas as linhagens aumentam a quantidade de RNA, no entanto após $24 \mathrm{~h}$, todas as linhagens de melanoma mantiveram o aumento da taxa de RNA, enquanto as linhagens CSB não apresentam o mesmo comportamento.

Como o ensaio de recuperação de RNA após exposição à UV indicou que todas as linhagens apresentam capacidade de recuperação, o que nos sugere que o sistema de reparo via NER possa estar funcionamento sem possíveis mutações ou alterações devido ao processo de transformação maligna do melanoma, pôde-se em seguida verificar se a ausência de hHR23B afetaria o reparo de lesões UV nas linhagens de melanoma.

Desta maneira, procurou-se analisar a cinética de reparo de lesões causadas por UVB nas linhagens de melanoma após irradiação. Para tal as três linhagens foram expostas a $120 \mathrm{~J} / \mathrm{m}^{2}$ de UVB e tiveram seus DNA extraídos nos tempos de 0h logo após a irradiação, e após 6 e 24h. Como controle, da reação foi- se usado DNA da mesma linhagem não irradiado. Cerca de 100 - 300 ng de DNA extraído de cada condição foi imobilizado em membrana Hybond para dot-blo e incubado com anticorpos específicos para lesões do tipo CPD e também para lesões do tipo fotoproduto 6-4. Como controle da quantidade de DNA aplicada, a mesma quantidade aplicada para revelação dos danos de DNA também foi aplicada em membrana Hybond após tratamento prévio com SYBR Green Gold. A quantidade de DNA foi 
visualizada sob luz UV. O ensaio foi realizado em triplicata e os valores obtidos da densitometria foram plotados em gráfico. Os resultados demonstram que há uma menor atividade de reparo de DNA tanto para fotoprodutos 6-4 (Figura 29A), quanto para lesões do tipo CPD (Figura 29B) nas linhagens que possuem menor expressão de hHR23B. No entanto, o reparo de lesões 6-4PP foi mais eficiente em Skmel-37 em $6 \mathrm{~h}$ e 24h após irradiação. Já para as lesões do tipo CPD, o reparo foi mais eficiente apenas após 6h de irradiação, enquanto para 24h após, não houve diferença estatística.
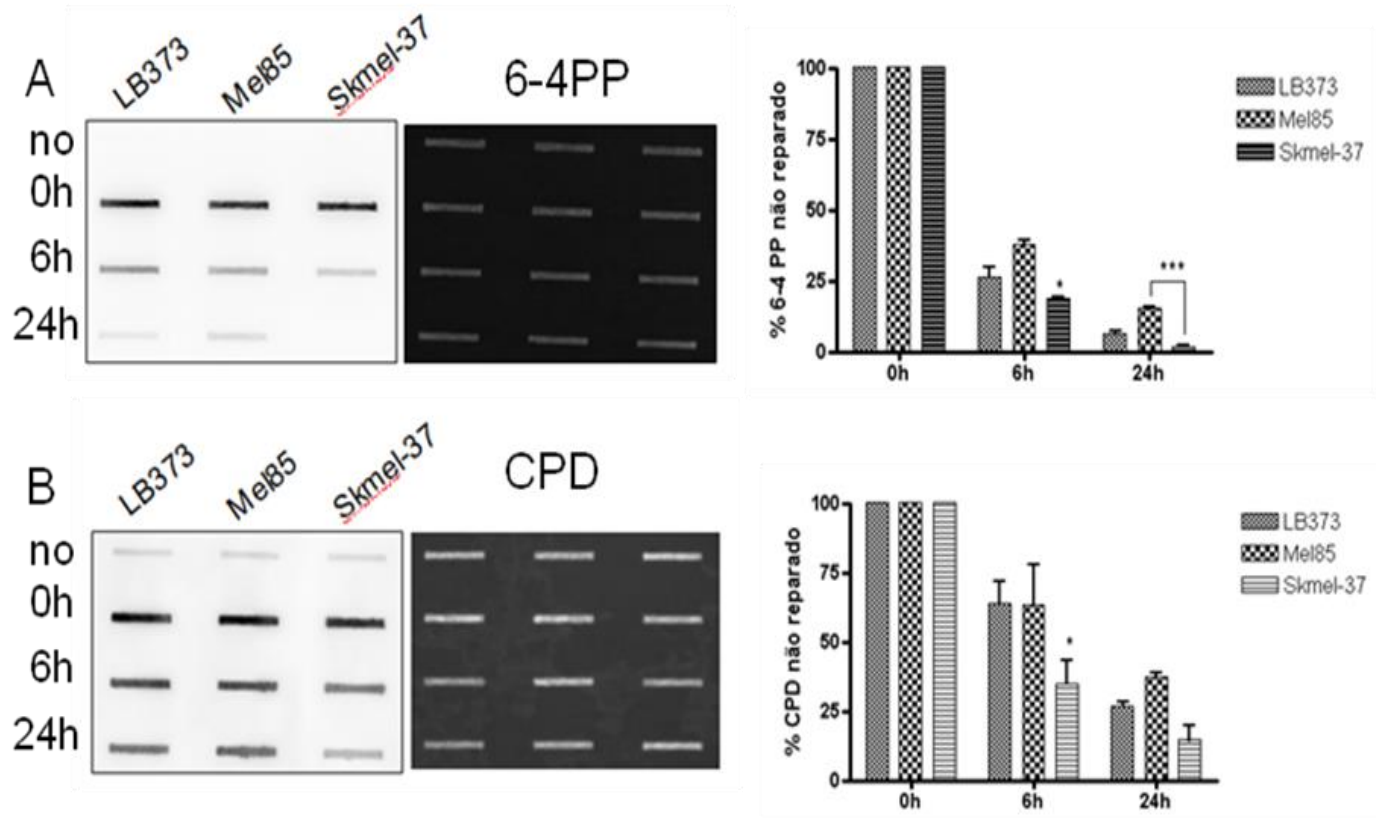

Figura 29. Cinética de reparo de lesões do tipo fotoproduto 6-4PP (A) e lesões do tipo CPD (B). Os gráficos representam média e erro padrão de três experimentos independentes. $* \mathrm{p}<0.05$, $* * * \mathrm{p}<0.001$.

\subsubsection{Expressão e estabilidade de XPC nas linhagens de melanoma}

No que se refere a sua participação na via de reparo de DNA NER, hHR23B está relacionado a estabilidade da proteína XPC, a qual funciona como proteína de reconhecimento das lesões nas fitas não transcritas do DNA. Para averiguar o papel de hHR23B na expressão e estabilidade de XPC, foi realizado western blotting nas 
linhagens de melanoma após UVB (Figura 30).

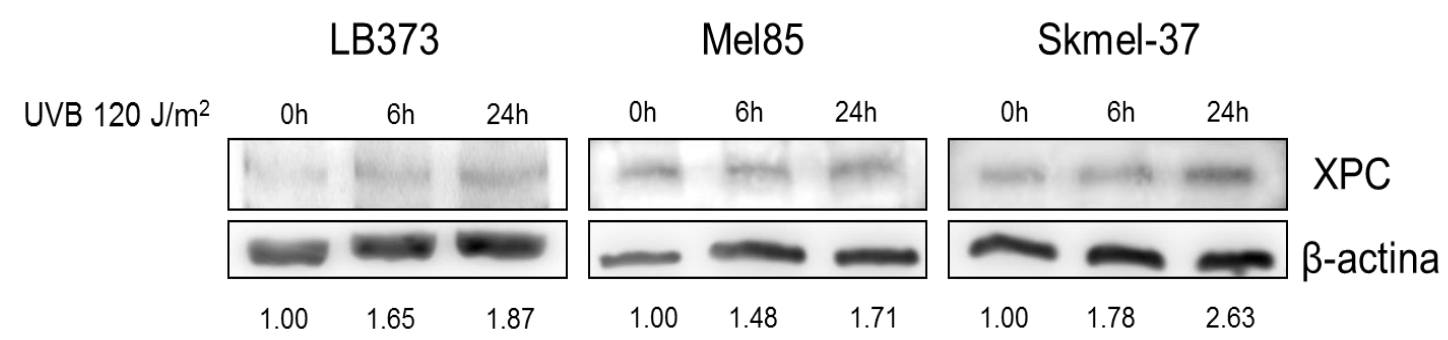

Figura 30. Expressão de XPC nas linhagens de melanoma após UVB.

A análise do western blotting para XPC, demonstrou inicialmente que nas células Skmel-37 (alta expressão de hHR23B), a quantidade de XPC foi maior em comparação com as outras linhagens de melanoma com menor expressão de hHR23B. Como tal resultado pode estar relacionado à biologia de cada linhagem, mascarando o possível efeito da expressão de hHR23B, foi-se testado a estabilidade de XPC na presença de $40 \mu \mathrm{M}$ de ciclohexamida ( $\mathrm{CHX}$ ). $\mathrm{CHX}$ funciona como inibidor do processo de tradução de proteínas, sendo um importante composto para averiguação da estabilidade de proteínas, uma vez que a síntese de novas proteínas fica comprometida devido à ação de CHX.

Desta maneira, as linhagens foram tratadas por diferentes tempos com $\mathrm{CHX}$ e o extrato protéico resultante foi analisado por western blotting. O resultado, o qual pode ser visualizado na figura 31, demonstra que a estabilidade de XPC é relativamente menor nas linhagens que não possuem hHR23B quando comparado com a linhagem Skmel-37, que possuem alta expressão da proteína. 


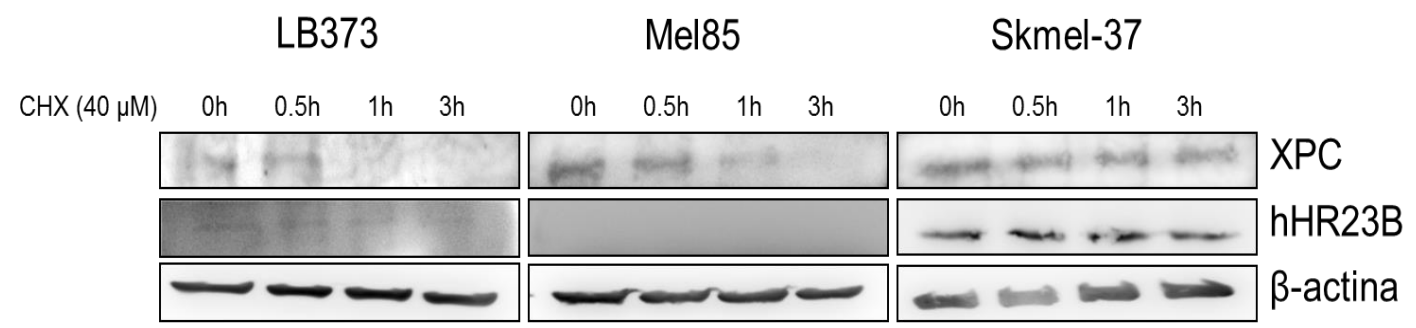

Figura 31. Estabilidade de XPC nas linhagens de melanoma após tratamento com $40 \mu \mathrm{M}$ de CHX.

\subsection{7 - Expressão e estabilidade de p53 nas linhagens de melanoma}

Além da expressão de XPC, o qual age no reconhecimento de lesões por UV, a proteína DDB-2 (também descrita como XPE) também auxilia no reconhecimento de lesões, principalmente lesões do tipo CPD (Fitch et al., 2003). Tanto XPC quanto DDB-2 têm sido descritas como proteínas expressas sob influência de p53 (Barckhausen et al., 2014). Além disso, hHR23B foi descrito como proteína relacionada a estabilidade de p53 (Wu et al., 2010).

Diante destes conhecimentos prévios, foi-se também verificado a expressão de DDB-2 e p53 nas linhagens de melanoma. Os resultados mostrados na figura 32 demonstram que DDB-2 se encontra expresso em ambas as linhagens e sendo responsivo à indução por UV em ambas as linhagens, principalmente em Mel85 e Skmel-37, embora em tempos diferentes (maior expressão a 24h em Mel85 e em 8h para Skmel-37 e LB373). Quanto à p53, em ambas as linhagens p53 esteve expresso após a exposição à UVB. 


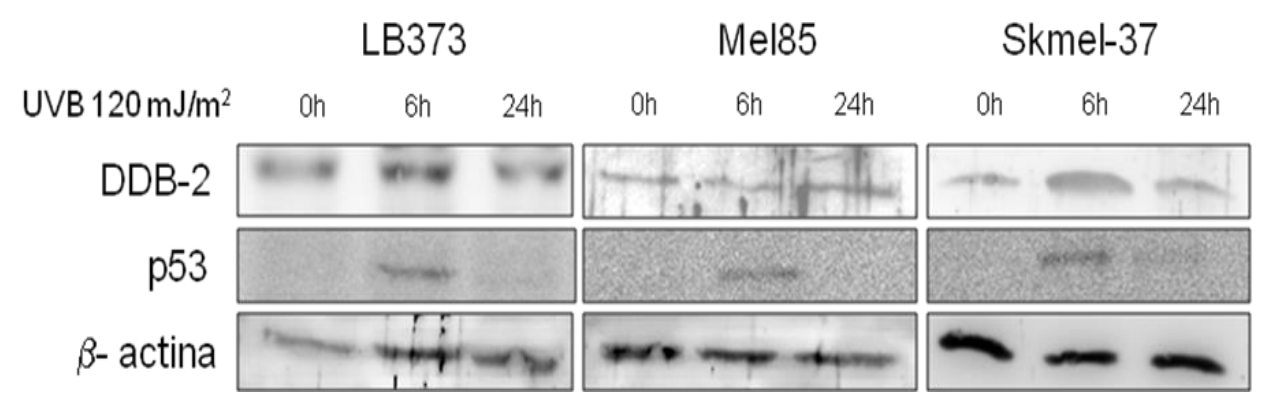

Figura 32. Expressão de DDB-2 e p53 nas linhagens de melanoma após UVB.

A seguir, investigou-se se a ausência de hHR23B nas células, poderia estar relacionada a menor estabilidade de p53. Para tal, o mesmo ensaio com CHX realizado para XPC foi feito, no entanto, como a vida média de p53 é menor, o tempo analisado também foi menor. O resultado mostrado na figura 33, demonstra uma informação importante no que diz respeito a possibilidade de hHR23B estar relacionado a estabilidade de p53. Nas células Skmel-37 a estabilidade e quantidade de p53 foi visualmente maior que nas demais linhagens.

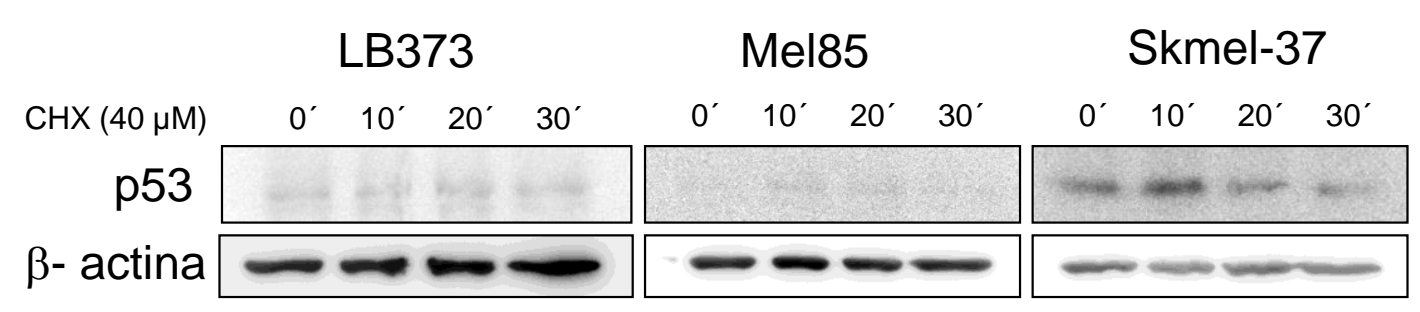

Figura 33. Estabilidade de p53 nas linhagens de melanoma após tratamento com cicloheximida.

\subsubsection{Imunolocalização de hHR23B e XPC na linhagem de melanoma Skmel-37}

Baseando-se nos resultados a partir da imuno-histoquimica do TMA, onde a expressão de hHR23B pode ser observada em regiões nucleares e também citoplasmáticas, procurou-se verificar sua localização subcelular na linhagem Skmel-37. Como hHR23B está envolvido na estabilidade e auxilio da função de XPC através de interação 
protéica, nós verificamos a localização subcelular destas proteínas.

O resultado representativo mostrado na figura 34 sugere que há maior localização proximal de hHR23B e XPC após os tempos de 2 e 6 h após irradiação com $120 \mathrm{~J} / \mathrm{m}^{2}$ de UVB. Já às $24 \mathrm{~h}$, verifica-se que a expressão de XPC mostra-se bem diminuída, uma vez que no merge das imagens a 24h, a expressão de hHR23B se mostra maior que a marcação de XPC. 

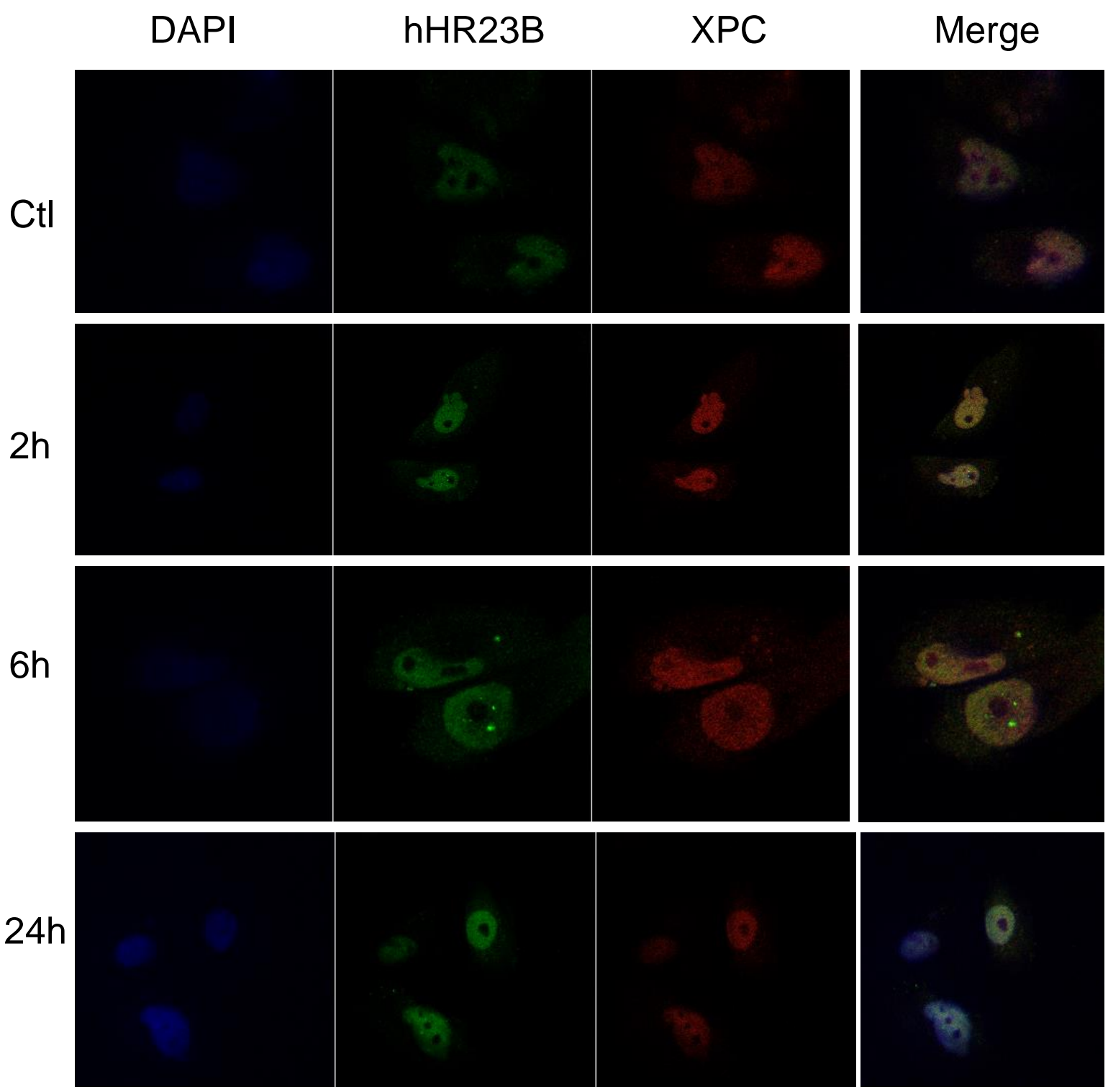

Figura 34. Imuno-colocalização de hHR23B e XPC na linhagem Skmel-37.

\subsubsection{Inibição da expressão de hHR23B e XPC por esiRNA}

Para a inibição de hHR23B e XPC foi-se usado a metodologia de siRNA. Como descrito na seção de Materiais e Métodos (seção 3.19), optou-se pelo uso de esiRNA, composto de diferentes oligos nucleotídeos para silenciamento, os quais têm por objetivo aumentar a eficiência do processo. O primeiro passo adotado foi a otimização da quantidade de esiRNA usado para o silenciamento gênico, onde diferentes 
concentrações foram usadas sendo a eficiência do silenciamento observada por real-time PCR após 24h de transfecção. Como controle foi usado esiRNA contra Luciferase 1 (Sigma Aldrich). Uma vez determinado as melhores concentrações de oligos (descritos na seção 3.19), o silenciamento de hHR23B e XPC foi verificado em relação ao acúmulo de proteína. Os resultados para o uso de esiRNA para hHR23B quanto a seu efeito em relação a quantidade de proteína bem para o nível do transcrito, conforme uso de concentração padronizada pode ser vista na figura 35. Já para os efeitos quanto ao uso de esiRNA para XPC pode ser visto na figura 36.
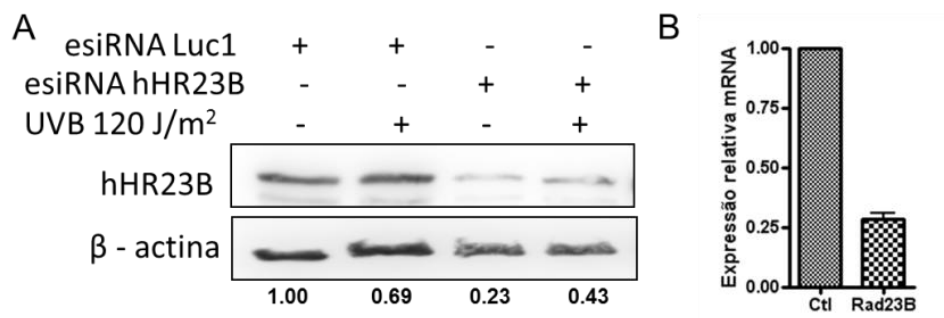

Figura 35. Uso de esiRNA para hHR23B. (A) Western Blotting mostrando diminuição da quantidade de hHR23B. (B) Efeito do uso de esiRNA na expressão gênica de hHR23B, mensurado por Real-Time PCR.
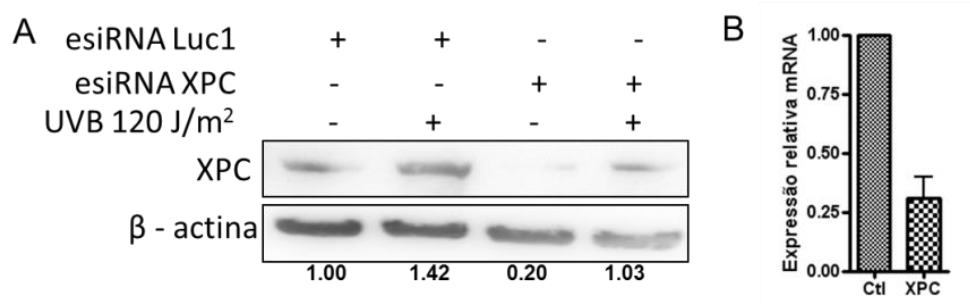

Figura 36. Uso de esiRNA para XPC. (A) Western Blotting mostrando diminuição da quantidade de XPC. (B) Efeito do uso de esiRNA na expressão gênica de XPC, mensurado por Real-Time PCR.

\subsubsection{Silenciamento de hHR23B e estabilidade e expressão de XPC}

Linhagens de melanoma LB373 e Mel85 que apresentavam baixa expressão de hHR23B também demonstravam menor acumulação e estabilidade de XPC. Para confirmar o papel de hHR23B na estabilidade e consequente acúmulo de XPC após UVB, Skmel-37 foi silenciada para hHR23B usando esiRNA e exposta à UVB para 
estimular a expressão de XPC e também tratada com CHX para testar a estabilidade de XPC após silenciamento de hHR23B. O papel de hHR23B na estabilidade e funcionamento de XPC já tem sido descrito dentro do funcionamento da via NER ( $\mathrm{Ng}$ et al., 2003), no entanto a confirmação desta função reforça a hipótese de que a perda de hHR23B em melanomas contribui para a aquisição de mutações causadas por exposição à radiação solar, da qual UVB é o principal componente carcinogênico.

Primeiramente, para verificar se a diminuição da expressão de hHR23B altera a estabilidade de XPC contribuindo assim para sua maior degradação, células Skmel-37 foram transfectadas com esiRNA e após $48 \mathrm{~h}$ tratadas com $40 \mu \mathrm{M}$ de cicloheximida $(\mathrm{CHX})$ por $3 \mathrm{~h}$. Após as $3 \mathrm{~h}$ foi extraído proteína para posterior western blotting. $\mathrm{O}$ resultado ilustrado na figura 37A denota a importância de hHR23B, uma vez que sua inibição por siRNA contribuiu para a maior degradação de XPC em Skmel-37. O uso de cicloheximida, inibidor do processo de tradução de proteínas sendo um importante composto para averiguação da estabilidade de proteínas, demonstrou que com a nãoprodução de mais proteínas, a quantidade de XPC diminui mais rapidamente na ausência de hHR23B, corroborando com os dados anteriores para as linhagens LB373 e Mel85 e também com dados prévios na literatura para a função de hHR23B na estabilidade de XPC (Okuda et al., 2004)

Como o resultado anterior demonstrou menor estabilidade de XPC, a expressão de XPC na situação de silenciamento de hHR23B também foi averiguada após $6 \mathrm{~h}$ de irradiação com UVB (Figura 37B). O resultado demonstrou menor acumulação protéica de XPC na vigência de esiRNA para hHR23B quando comparada as células transfectadas com esiRNA negativo após irradiação por UVB. Tal efeito pode ser 
atribuído ao silenciamento de hHR23B, onde a menor estabilidade de XPC, vista pelo ensaio com CHX, leve ao menor acúmulo de XPC após UVB.

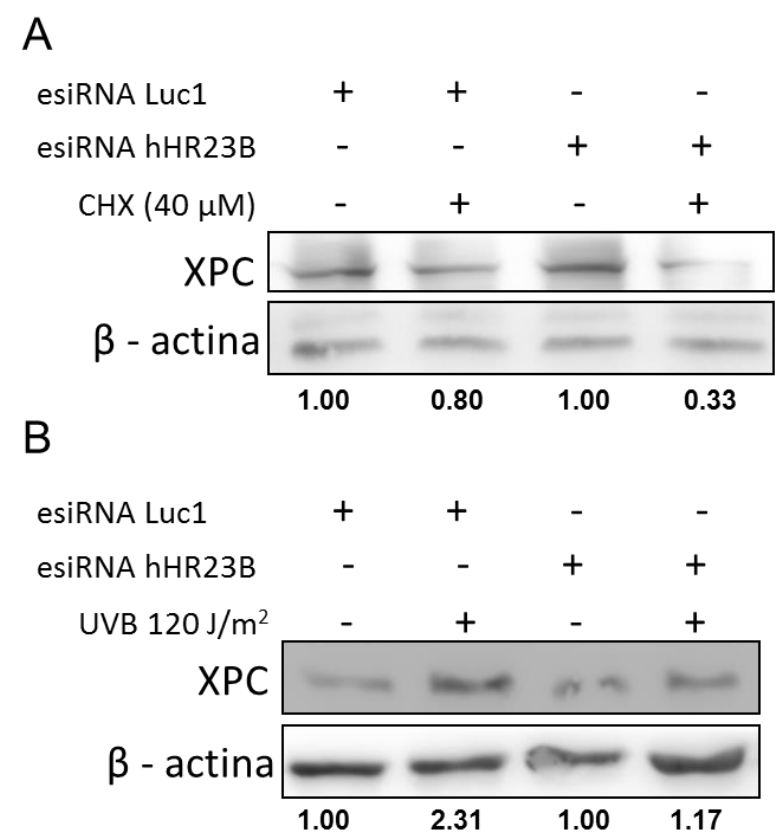

Figura 37. Estabilidade e expressão de XPC. Estabilidade de XPC após uso de esiRNA para hHR23B e CHX por 3h (A). Expressão de XPC após esiRNA para hHR23B e irradiação com UVB.

4.2.11 Efeito do silenciamento de hHR23B e XPC na cinética de reparo de lesões UV

Os resultados mostrados até o presente momento demonstraram que a inibição de hHR23B contribui para a menor estabilidade e consequente acúmulo de XPC após UVB. Assim, tais resultados sugerem que a diminuição da expressão de hHR23B leva a menor a estabilidade de XPC, culminando portanto com menor eficiência de reparo de DNA após UVB. Em tal situação, a perda de hHR23B poderia facilitar a aquisição de mutações e contribuir para o processo carcinogênico de melanomas.

Para testar essa hipótese sobre a menor eficiência do reparo UVB, procurou-se medir a taxa de reparo das duas principais lesões causadas por UV em função do tempo nas células Skmel-37 com o silenciamento de hHR23B. Absorção do UVB pelo DNA 
pode levar a dois tipos de lesões: os fotoprodutos 6-4, gerados entre resíduos de pirimidinas adjacentes, e por dímeros de pirimidinas ou ciclobutanos (CPD), formados especificamente por resíduos adjacentes de timina ou citosina. Dímeros de pirimidina são considerados mais carcinogênicos que fotoprodutos $6-4$, formando-se cerca de três vezes mais e sendo menos eficientemente reparados. (Pfeifer et al., 2005). Ambos os tipos de lesão podem levar a mutações genéticas tais como transições $\mathrm{C} \rightarrow \mathrm{T}$ e $\mathrm{CC} \rightarrow \mathrm{TT}$, este último característico de lesão por UV.

Para avaliar o papel de hHR23B na cinética de reparo de lesões UVB, células Skmel-37 foram transfectadas com esiRNA para XPC e hHR23B e após 48h irradiadas com UVB. Imediatamente após irradiação (0h), 6h e 24h, o DNA das células foi extraído para posterior utilização em dot blot (conforme detalhadamente descrito em materiais e métodos). Primeiramente foi averiguada a capacidade de reparo de lesões do tipo fotoproduto 6-4 (Figura 38 A e B). Resultado mostra que o silenciamento de ambos XPC ou hHR23B leva a menor eficiência de reparo de lesões deste tipo de lesão. 

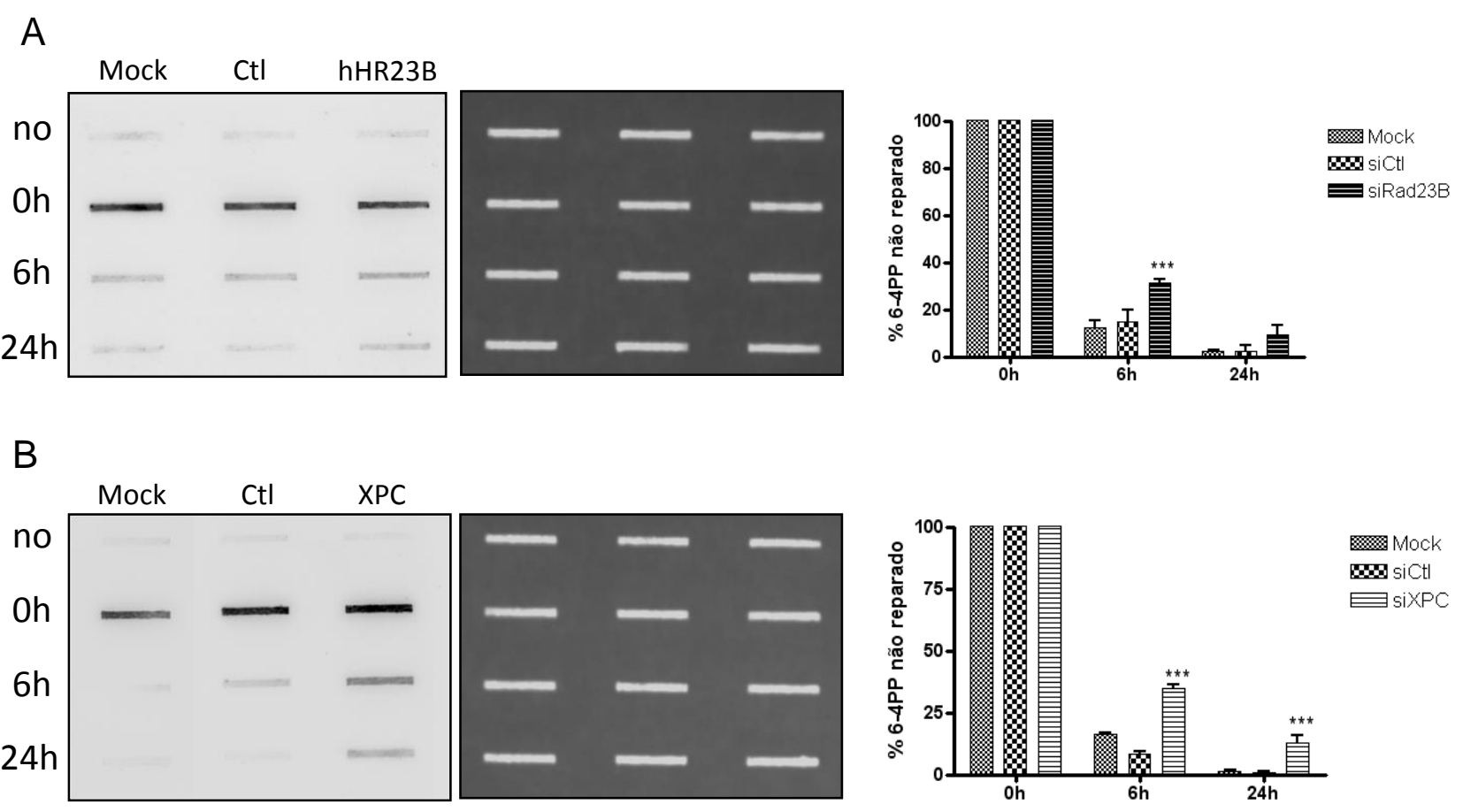

Figura 38. Dot-Blot para reparo de lesões do tipo fotoproduto 6-4 (6-4PP). (A) cinética de reparo de 64PP em Skmel-37 silenciadas com esiRNA para XPC. (B) cinética de reparo de 6-4PP em Skmel-37 silenciadas com esiRNA para hHR23B. Os gráficos ao lado mostram a quantificação da intensidade das bandas do dot-blot mensurado com auxílio do programa Image J. O gráfico mostra média e o erro padrão de três experimentos independentes. $* * * \mathrm{p}<0.001$.

Em seguida, usando a mesmo DNA irradiado verificou-se a capacidade de reparo de lesões do tipo CPD (Figura 39 A e B). No entanto, neste caso, apenas para o silenciamento de XPC pode-se observar significativo diminuição do reparo após 24h. Já no caso de hHR23B, embora visualmente sugestivo, essa diferença não se mostrou significativa quando observada após uso de estatística. 

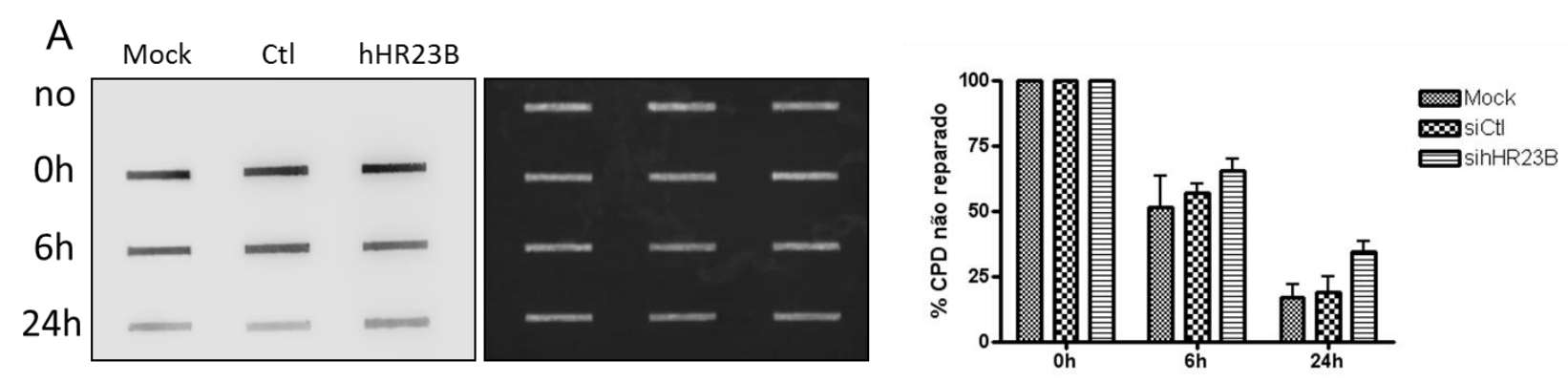

$\mathrm{B}$
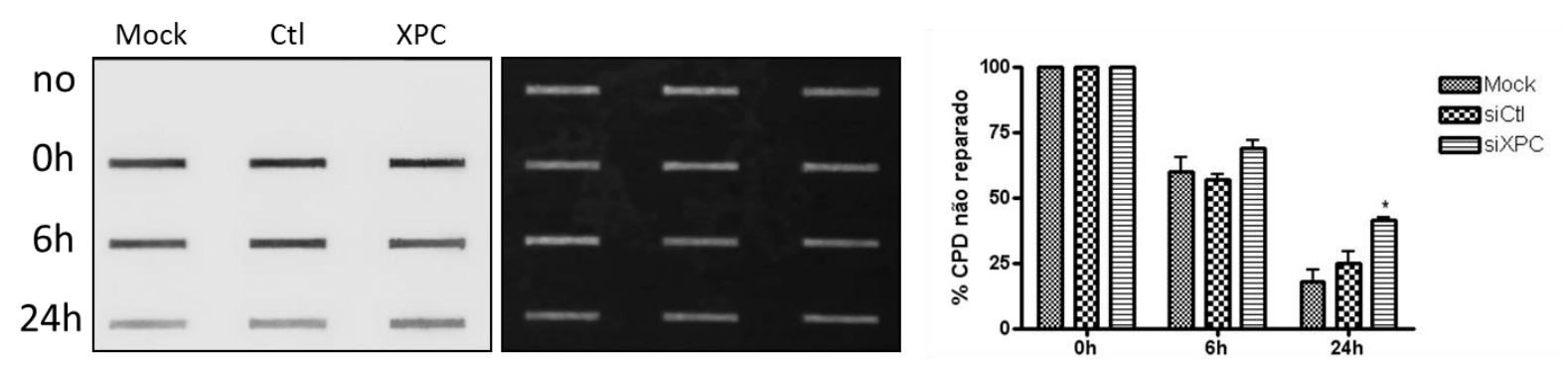

Figura 39. Dot-Blot para reparo de lesões do tipo CPD. (A) cinética de reparo de CPD em Skmel-37 silenciadas com esiRNA para XPC. (B) cinética de reparo de CPD em Skmel-37 silenciadas com esiRNA para hHR23B. Os gráficos ao lado mostram a quantificação da intensidade das bandas do dot-blot mensurado com auxílio do programa Image J. O gráfico mostra média e o erro padrão de três experimentos independentes. $* \mathrm{p}<0.05$

\subsubsection{Sensibilidade a UVB em Skmel-37 após silenciamento de hHR23B e XPC}

Como os resultados para cinética de reparo sugerem que possa haver uma diminuição da velocidade de reparo de lesões causadas por UVB, principalmente em relação à lesões do tipo 6-4P, quando silenciamos hHR23B ou XPC, verificou-se se essas situações alterariam a sensibilidade a UVB.

Desta maneira verificou-se a porcentagem de células hipodiplóides (morte celular) após $48 \mathrm{~h}$ de irradiação. As células Skmel-37 previamente transfectadas para esiRNA para hHR23B e XPC foram plaqueadas em placas de 12 wells e irradiadas com UVB à 60 e $120 \mathrm{~J} / \mathrm{m}^{2}$. Concomitantemente ao ensaio de morte celular foi realizado ensaio clonogênico das amostras irradiadas para morte celular. Para isso, 300 células de cada poço das placas de 12 wells usadas para morte celular foram plaqueadas e deixadas para formação de clones. Os resultados podem ser visto na figura 40. 


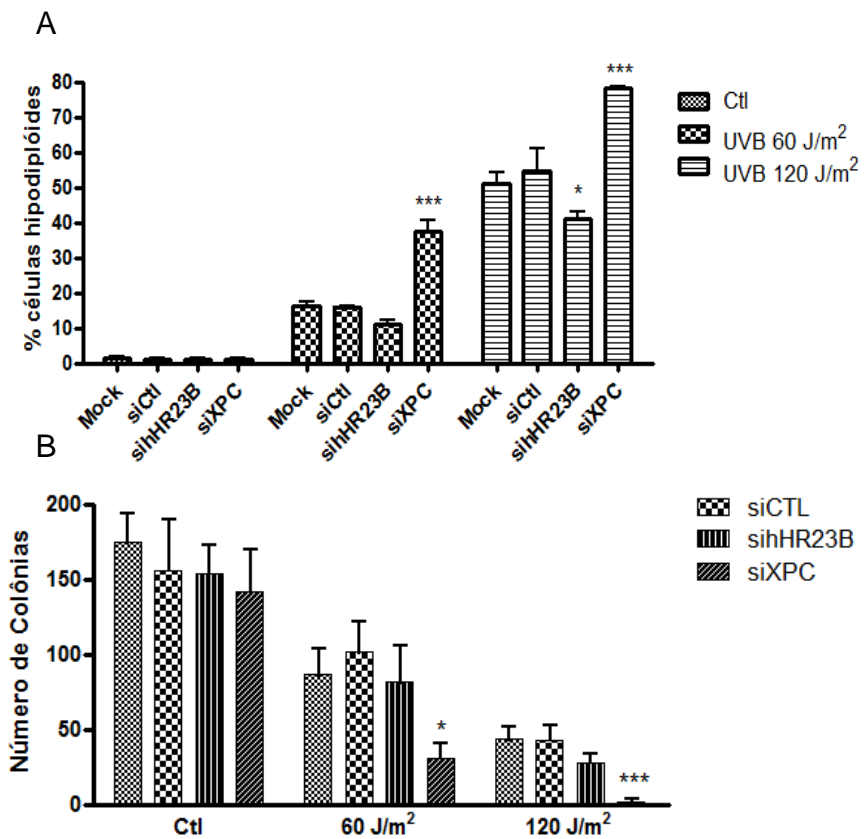

Figura 40. Sensibilidade de células Skmel-37 após uso de esiRNA para hHR23B e XPC. (A) porcentagem de células hipodiplóides analisados por incorporação de PI. (B) ensaio clonogênico a partir do ensaio de morte celular. $* \mathrm{p}<0.05, * * * \mathrm{p}<0.001$. Resultados mostram média e desvio padrão de ensaio em triplicata. Ensaio representativo de triplicatas independentes.

Os resultados demonstram que a inibição de XPC tanto aumenta a morte celular (Figura 40A) quanto também diminui a capacidade das células em formar colônias após irradiação (Figura 40B). Já para hHR23B os resultados para morte celular $\left(120 \mathrm{~J} / \mathrm{m}^{2}\right)$ sugerem uma taxa de morte menor quando comparados ao controle com esiRNA para LUC1 (Figura 40A). No entanto, quando se observa a capacidade de formação de colônias, o silenciamento para hHR23B demonstra que as células apresentam capacidade estatisticamente igual ao controle (Figura 40B). Os resultados sugerem que a inibição de hHR23B possa alterar a sensibilidade a morte por UVB após 48h, diminuindo assim o mecanismo de morte até o tempo analisado. Porém essa diminuição de morte não é acompanhada por capacidade de formação de clones, pois não houve diferença entre a condição controle. $\mathrm{O}$ que os resultados sugerem é que a inibição de 
hHR23B possa momentaneamente diminuir a taxa de morte, mas essa aparente sobrevivência não é persistente, pois não favorece a formação de clones.

\subsubsection{Papel de hHR23B e XPC na resposta a quimioterápicos}

Uma vez que muitos agentes quimioterápicos agem causando danos no DNA, os quais podem ser reparados pela via de reparo NER levando assim a resistência à quimioterapia em tumores, buscou-se avaliar se a inibição de hHR23B de alguma maneira aumentaria a resposta à quimioterapia. Para tal, optou-se por utilizar quimioterápicos que de alguma maneira estivesse relacionados à participação da via NER no reparo das lesões causadas por tais agentes quimioterápicos, seja por criação de adutos no DNA (as quais são preferencialmente reparados pela via NER), ou seja, pela oxidação ou alquilação de bases. Para este último caso, alguns trabalhos sugerem a participação seja de XPC (D’Errico et al., 2006) ou mesmo de hHR23B (Miao et al., 2000) na atividade de reparo de lesões oxidativas. Desta maneira, usaram-se os quimioterápicos: cisplatina (que pode atuar causar adutos no DNA), dacarbazina e temozolamida (comumente usados na quimioterapia de melanomas e que causam alquilações em bases do DNA), etoposídeo (inibidor de DNA topoisomerase e que pode também causar adutos de DNA), 5'Fluouracil (antimetabólito que atua na inibição da timidilato sintase, inibindo assim a síntese de timina) e Tunicamicina (agente causador de estresse de reticulo devido a sua atuação na inibição de importante passo do folding de proteínas).

5' Fluouracil foi escolhido devido a sua eficácia poder ser mediada pela ação da proteína glicosilase TDG (Thymine DNA Glysosylase)(Kunz et al., 2009) que atua no reparo de lesões em timinas, sendo que TDG pode também interagir com XPC (Shimizu et al., 2003). Já a escolha de Tunicamicina, sua ação levando a situação de estresse de 
reticulo pode levar a aumento de espécies reativas de oxigênio que causam danos no DNA (onde novamente o complexo XPC-hHR23B pode atuar modulando proteínas da via BER), ou a mesma situação de estresse desencadeia processos de degradação de proteínas, papel que pode ser modulado por hHR23B devido a seus domínios de ligação a ubiquitina (Dantuma et al. 2009).

Para verificar o efeito do silenciamento de hHR23B na resposta a agentes quimioterápicos, células Skmel-37 foram transfectadas com esiRNA para hHR23B e após $48 \mathrm{~h}$ de inibição, foram tratadas para os agentes citados. As concentrações usadas foram estimadas com base na literatura específica para uso destes agentes em linhagens de melanoma ou mesmo de uso rotineiro no laboratório (detalhes na seção de materiais e métodos). Após 48h, as células foram extraídas e verificadas para morte celular por incorporação de iodeto de propídeo. Os resultados podem ser vistos na figura 41.

Os resultados demonstraram primeiramente que a inibição de hHR23B e também de XPC levou a maior sensibilidade das células a exposição a doxorrubicina (Figura 41). Como o silenciamento de hHR23B e XPC sugeriu a participação deste complexo proteico da via NER na resposta a doxorrubicina, surgiu à questão de verificar se nas linhagens de melanoma que possuem baixa expressão de hHR23B apresentariam a mesma sensibilidade a doxorrubicina. Para responder esta questão, nós voltamos a utilizar as linhagens de melanoma LB373 e Mel85 (as quais apresentavam baixa expressão de hHR23B) para avaliar a sensibilidade a doxorrubicina, tendo em comparação a linhagem Skmel-37, a qual expressa hHR23B. Desta maneira, as três linhagens foram plaqueadas e após $24 \mathrm{~h}$, foram expostas a doxorrubicina à concentração de $100 \mathrm{ng} / \mathrm{ml}$ por $48 \mathrm{~h}$ e analisadas quanto a morte celular por incorporação de iodeto de propídio em citometria de fluxo. A exposição das linhagens de melanoma à 
doxorrubicina mostrou que a linhagem Skmel-37, a qual expressa hHR23B, possui sensibilidade "intermediária" à ação do quimioterápico quando comparada com as linhagens LB373 e Me185, as quais não expressam hHR23B (Figura 41). Tal resultado sugere que outras variáveis além do complexo XPC-hHR23B, mais precisamente a via NER, podem estar envolvidas na sensibilidade a doxorrubicina.
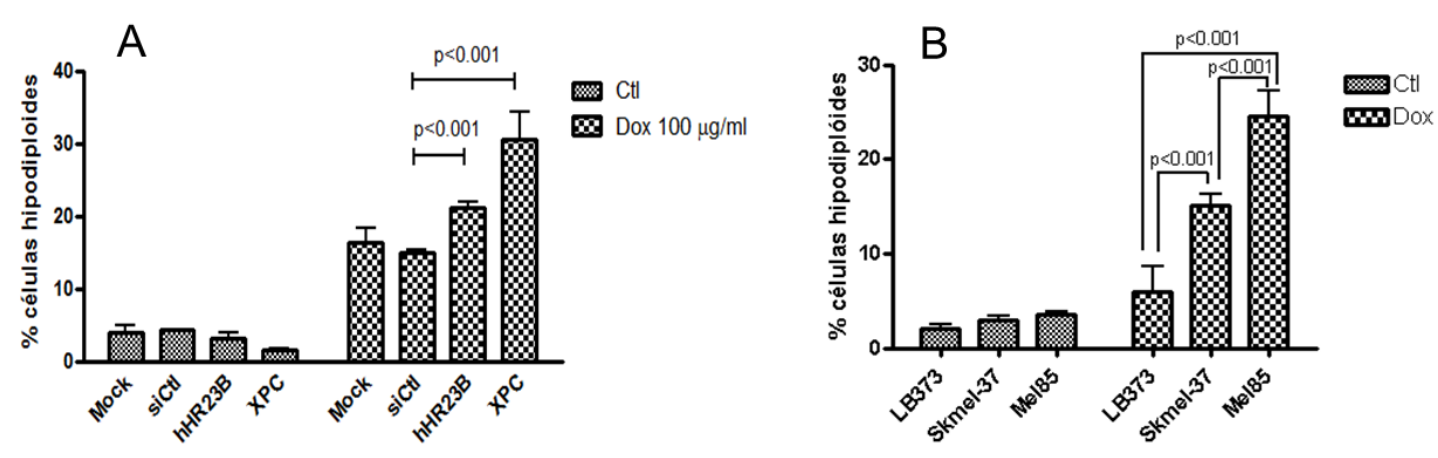

Figura 41. Sensibilidade das linhagens de melanoma à doxorrubicina. (A) efeito do silenciamento de hHR23B e XPC. (B) Sensibilidade das linhagens de melanoma à doxorrubicina. Resultados mostram média e desvio padrão de ensaio em triplicata. Ensaio representativo de triplicatas independentes.

Além de doxorrubicina, outros agentes quimioterápicos também foram utilizados. No caso do uso de Temozolomida e 5'Fluoracil, nenhuma diferença foi observada (Figura 42A e C). Já para o uso de etoposideo, curiosamente, a inibição de hHR23B levou a uma menor taxa de morte celular após 48 de tratamento (Figura 42B). Para cisplatina, apenas a inibição de XPC levou a um aumento na taxa de morte celular, no entanto, o silenciamento de hHR23B não alterou tal sensibilidade (Figura 42D).

Além dos agentes quimioterápicos usados, testou-se se hHR23B poderia contribuir para a sensibilidade ao agente tunicamicina, composto comumente usado para ativar estresse de reticulo endoplasmático, onde a atuação de tunicamicina impede um importante passo de glicosilação de proteínas recém-sintetizadas, levando a um acumulo 
de proteínas mal-enoveladas, disparando assim o processo conhecido como UPR (unfolded protein response). A ativação de UPR leva as células a ativarem um programa de degradação das proteínas mal-enoveladas acumuladas no reticulo endoplasmático, da qual hHR23B pode estar relacionado devido a seus domínios de ligação a proteínas ubiquitinadas (Dantuma et al., 2009). A persistência da ativação de UPR também pode levar as células a apoptose. Como hHR23B também apresenta os mesmos domínios de ligação a proteínas ubiquitinadas e também têm sido relacionado a regulação de degradação de proteínas, pode também de alguma maneira estar relacionado a sensibilidade a tunicamicina.

De maneira similar aos resultados encontrados para exposição à etoposídeo, o tratamento com tunicamicina levou as células previamente silenciadas para hHR23B a uma menor taxa de morte celular quanto comparada as células tratadas com esiRNA negativo (Figura 42E). No entanto, o silenciamento para XPC não alterou a susceptibilidade a tunicamicina, evidenciando assim um possível papel de hHR23B independente de sua função no NER. 

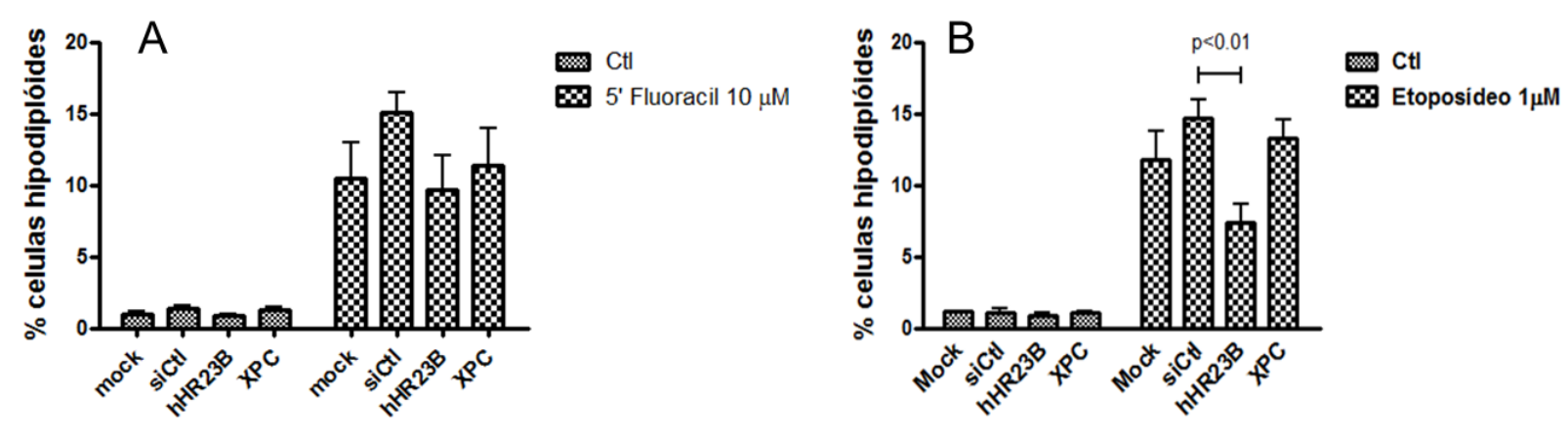

C
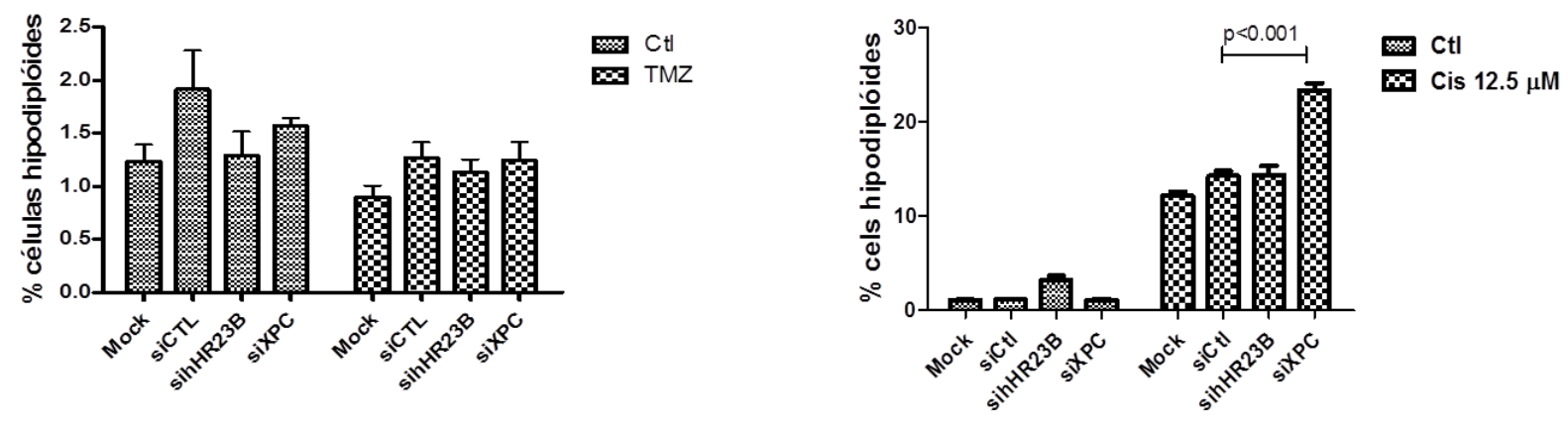

E

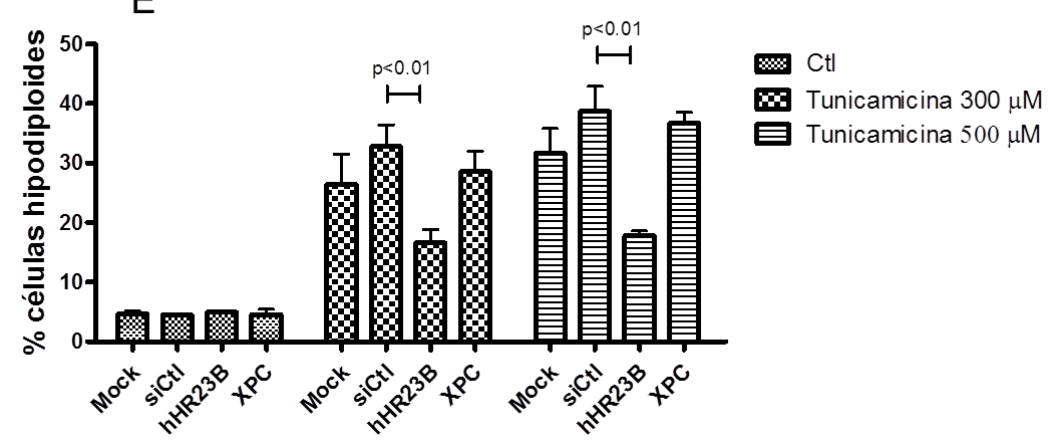

Figura 42. Sensibilidade das linhagens de melanoma à 5'Fluoracil (A) Etoposídeo (B), Temozolomida (C), Cisplatina (D) e Tunicamicina (E), após silenciamento de hHR23B e XPC. Resultados mostram média e desvio padrão de ensaio em triplicata. Ensaio representativo de triplicatas independentes. 


\subsection{Função de polimorfismos de XPC no risco de desenvolvimento de melanoma e na expressão gênica}

\subsubsection{Função dos polimorfismos de XPC no risco de melanomas}

Nosso grupo obteve resultados interessantes quanto ao envolvimento de genes da via NER e o desenvolvimento de melanoma (Gonçalves et al., 2011). Em um estudo caso-controle foi observado maior risco de desenvolvimento de melanoma em indivíduos que possuíam um haplótipo polimórfico no gene XPC (Tabela 3). Tal haplótipo é formado por três polimorfismos: uma inserção de 83 pares de bases de repetições AT no intron 9 (polimorfismo conhecido como PAT+), uma substituição de citosina para adenina no sitio de splicing do intron 11 (polimorfismo conhecido como IV11-6C/A) e a troca de uma Lisina por Glutamina no códon 939 da proteína (K939Q). Além disso, o mesmo estudo mostrou que os três polimorfismos apresentam forte desequilíbrio de ligação, sendo assim, herdados juntos no formato de um haplótipo. Alguns estudos sugeriram menor capacidade de reparo conferida a estes polimorfismos, principalmente em relação aos polimorfismos PAT+ e K939Q, no entanto tais estudos foram baseados em linfócitos de pacientes, método que pode estar sujeito a outras variações genéticas que não foram analisadas (Qiao et al., 2002). No entanto, uma maior análise do impacto destes polimorfismos, seja na estabilidade do mRNA, uma vez que dois dos polimorfismos estão localizados em regiões intrônicas (sendo uma delas no sitio de splicing), seja na atividade da proteína mediante a troca de lisina por glutamina no códon 939 ainda não foram devidamente exploradas, principalmente para neoplasias tais como o melanoma.

Não apenas as variações genéticas existentes em XPC aumentaram o risco para o desenvolvimento melanoma, como a associação das variações existentes de XPC com 
outros fatores de risco já conhecidos para melanoma também demonstrou aumento de risco (Tabela 4). Os resultados obtidos deste estudo sugerem que fatores que possam modular a atividade de XPC, como por exemplo, a existência de variações genéticas, podem também estar relacionados ao desenvolvimento de melanomas. Alguns estudos recentes têm demonstrado a existência de variações funcionais em alguns genes devido à presença de variações polimórficas (Altilia et al., 2012). Além disso, variações na expressão gênica específica de diferentes alelos também têm sido descritas, o que pode justamente acarretar em riscos diferenciais atribuídos a alelos específicos e determinadas doenças (Pillay et al., 2012).

Tabela 3. Frequência genotípica e risco associado a polimorfismos no gene $X P C$ e risco de melanoma. Dados extraídos de Gonçalves et al., 2011.

\begin{tabular}{|c|c|c|c|c|}
\hline Polimorfismos & Casos $n(\%)$ & Controles $n(\%)$ & OR $(95 \% \mathrm{CI})$ & ajustado OR $(95 \% \mathrm{CI})^{*}$ \\
\hline \multicolumn{5}{|l|}{$X P C$ PAT } \\
\hline$-/-$ & $65(33.8)$ & $114(54.8)$ & 1.00 & 1.00 \\
\hline$-/+$ & $85(44.3)$ & $73(35.1)$ & $2.04(1.32-3.16)$ & $1.77(1.13-2.78)$ \\
\hline$+/+$ & $42(21.8)$ & $21(10.1)$ & $3.51(1.91-6.43)$ & $3.27(1.75-6.12)$ \\
\hline$P A T+$ allele & 0.44 & 0.28 & & \\
\hline \multicolumn{5}{|l|}{$X P C$ IV11 -6C/A } \\
\hline$C C$ & $55(28.6)$ & $102(49.0)$ & 1.00 & 1.00 \\
\hline$C A$ & $97(50.5)$ & $83(39.9)$ & $2.17(1.40-3.36)$ & $2.04(1.29-3.22)$ \\
\hline$A A$ & $40(20.8)$ & $23(11.1)$ & $3.23(1.75-5.93)$ & $3.10(1.65-5.83)$ \\
\hline$A$ allele & 0.46 & 0.31 & & \\
\hline \multicolumn{5}{|l|}{ XPC LysK939Gin } \\
\hline Lys/Lys & $61(31.8)$ & $102(49.0)$ & 1.00 & 1.00 \\
\hline Lys/Gln & $93(48.4)$ & $85(40.9)$ & $1.83(1.19-2.82)$ & $1.73(1.10-2.71)$ \\
\hline $\mathrm{G} \ln / \mathrm{G} \ln$ & $38(19.8)$ & $21(10.1)$ & $3.03(1.63-5.63)$ & $2.89(1.52-5.50)$ \\
\hline $\begin{array}{l}\text { Gln allele } \\
\text { gene-gene interaction }\end{array}$ & 0.44 & 0.30 & & \\
\hline \multicolumn{5}{|l|}{$X P C$ haplotype } \\
\hline PAT -/-;-6CC,Lys/Lys & $47(30)$ & $95(53)$ & 1.00 & 1.00 \\
\hline PAT-/+;-6CA;Lys/Gln & $76(49)$ & $65(38)$ & $2.36(1.46-3.82)$ & $1.94(1.17-3.20)$ \\
\hline $\mathrm{PAT}+/+;-6 \mathrm{AA}, \mathrm{G} \ln / \mathrm{G} \ln$ & $33(21)$ & $17(9)$ & $3.92(1.98-7.76)$ & $3.64(1.77-7.48)$ \\
\hline PAT +-6 A Gln allele & 0.455 & 0.28 & & \\
\hline
\end{tabular}


Tabela 4. Associação de variações polimórficas de $X P C$ e demais fatores de risco para o risco de desenvolvimento de melanomas. Dados extraídos de Gonçalves et al., 2011.

\begin{tabular}{|c|c|c|c|c|}
\hline Variables & Cases $n(\%)$ & Controls $n(\%)$ & Crude OR & Adjusted OR $(95 \% \mathrm{Cl})$ \\
\hline \multicolumn{5}{|c|}{ Hair color and XPC haplotype } \\
\hline Black or brown/XPC 0 & $36(24.3 \%)$ & $83(50.3 \%)$ & 1.00 & 1.00 \\
\hline Black or brown/XPC 1-2 & $83(56.1 \%)$ & $72(43.6 \%)$ & 2.66 & $2.18(1.14-4.15)$ \\
\hline Blonde or red/XPC 0 & $10(6.8 \%)$ & $5(3.0 \%)$ & 4.61 & $2.11(0.40-11.09)$ \\
\hline Blonde or red/XPC 1-2 & $19(12.8 \%)$ & $5(3.0 \%)$ & 8.76 & $3.82(1.01-14.45)$ \\
\hline \multicolumn{5}{|c|}{ Eye color and XPC haplotype } \\
\hline Black or brown/XPC 0 & $34(23.1)$ & $76(46.1)$ & 1.00 & 1.00 \\
\hline Black or brown/XPC 1-2 & $71(48.3)$ & $69(41.8)$ & 2.30 & $1.75(0.89-3.41)$ \\
\hline Green or blue/XPC 0 & $12(8.2)$ & $13(7.9)$ & 2.06 & $1.67(0.50-5.61)$ \\
\hline Green or blue/XPC 1-2 & $30(20.4)$ & $7(4.2)$ & 9.58 & $7.42(2.30-23.87)$ \\
\hline \multicolumn{5}{|l|}{ Freckles and XPC haplotype } \\
\hline Any/Rare/XPC 0 & $25(17.2)$ & $70(44.0)$ & 1.00 & 1.00 \\
\hline Any/Rare/XPC 1-2 & $61(42.1)$ & $64(40.3)$ & 2.67 & $2.07(1.01-4.24)$ \\
\hline Few/Many $/ X P C 0$ & $18(12.4)$ & $12(7.6)$ & 4.20 & $1.62(0.56-4.71)$ \\
\hline Few/Many/XPC 1-2 & $41(28.3)$ & $13(8.2)$ & 8.83 & $3.66(1.41-9.47)$ \\
\hline \multicolumn{5}{|c|}{ Sunburn in childhood and XPC haplotype } \\
\hline $\mathrm{No} / X P C 0$ & $13(8.8)$ & $52(33.8)$ & 1.00 & 1.00 \\
\hline $\mathrm{No} / X P C 1-2$ & $34(23.0)$ & $46(29.9)$ & 2.96 & $2.32(0.96-5.56)$ \\
\hline Yes/XPC 0 & $33(22.3)$ & $25(16.2)$ & 5.28 & $1.77(0.59-5.31)$ \\
\hline Yes/XPC 1-2 & $68(45.9)$ & $31(20.1)$ & 8.77 & $3.39(1.29-8.87)$ \\
\hline \multicolumn{5}{|c|}{ Sunburn in adolescence and XPC haplotype } \\
\hline $\mathrm{No} / X P C 0$ & $15(10.4)$ & $52(34.0)$ & 1.00 & 1.00 \\
\hline $\mathrm{No} / X P C 1-2$ & $35(24.3)$ & $55(36.0)$ & 2.21 & $1.86(0.81-4.27)$ \\
\hline Yes/XPC 0 & $29(20.1)$ & $24(15.7)$ & 4.19 & $2.37(0.81-6.98)$ \\
\hline Yes/XPC 1-2 & $65(45.1)$ & $22(14.4)$ & 10.24 & $5.42(2.00-14.69)$ \\
\hline \multicolumn{5}{|c|}{ Pigmented lesions removed and XPC haplotype } \\
\hline $\mathrm{No} / \mathrm{XPC} 0$ & $17(11.5)$ & $73(44.2)$ & 1.00 & 1.00 \\
\hline $\mathrm{No} / X P C 1-2$ & $51(34.5)$ & $62(37.6)$ & 3.53 & $2.57(1.17-5.66)$ \\
\hline Yes/XPC 0 & $29(19.6)$ & $15(9.1)$ & 8.30 & $4.68(1.73-12.69)$ \\
\hline Yes/XPC 1-2 & $51(34.5)$ & $15(9.1)$ & 14.60 & $7.19(2.81-18.38)$ \\
\hline \multicolumn{5}{|c|}{ European ancestry and XPC haplotype } \\
\hline $\mathrm{No} / X P C 0$ & $23(15.7)$ & $59(37.3)$ & 1.00 & 1.00 \\
\hline $\mathrm{No} / X P C 1-2$ & $34(23.1)$ & $44(27.9)$ & 1.98 & $2.41(1.04-5.60)$ \\
\hline Yes/XPC 0 & $23(15.7)$ & $23(14.60$ & 2.57 & $2.07(0.75-5.75)$ \\
\hline Yes/XPC 1-2 & $67(45.6)$ & $32(20.3)$ & 5.37 & $3.75(1.61-8.72)$ \\
\hline
\end{tabular}

${ }^{\mathrm{f}}$ Arabicnumbers in XPCgene: 0 indicates a no-riskallele(PAT;IV11-6C;Lys) and 1-2 indicates a genetic model grouping the heterozygous a (PAT+;IV11-6A;Gln).

- Adjusted for age, sex, educational level, eye color, hair color, phototype, nevi and sunburn.

- Test for multiplicative interaction obtained from logistic regression models with adjustment for age, sex, educational level and main effe

Os resultados apontados pelo estudo claramente demonstram um papel dos polimorfismos de XPC no risco de melanoma (Gonçalves et al., 2011). Tais dados serviram de base para a proposta de analisar o possível impacto funcional destes polimorfismos. Devido a presença de polimorfismos intrônicos e o forte desiquilíbrio de ligação entre as variantes, buscou-se avaliar o possível impacto funcional na 
estabilidade e expressão gênica de XPC, usando como marcador surrogado o polimorfismo K939Q. As seções a seguir descrevem os resultados quanto à padronização e avaliação da expressão gênica de $X P C$.

\subsubsection{Genotipagem de linhagens de melanoma para os polimorfismos de XPC}

Seguindo os objetivos do projeto de avaliar o impacto dos polimorfismos de $X P C$ na expressão e funcionalidade do mesmo, procurou-se genotipar as linhagens de melanoma existentes no laboratório quanto aos genótipos de $X P C$. Neste caso, a genotipagem permitiria identificar linhagens que poderiam ser utilizadas como modelos para averiguar o impacto dos polimorfismos intrônicos de XPC na expressão e estabilidade dos transcritos. Os polimorfismos de $X P C$ são: presença de região de repetição de bases AT de 83 pares de bases localizados no intron 9 (XPC Poli AT); substituição de um citosina por adenina no sitio de splicing do exon 12 (XPC IV -6 C/A) e substituição do aminoácido lisina (K) por glutamina (Q) no códon 939. Os polimorfismos poli AT, XPC IV -6 A e 939Q são os alelos variantes do gene.

Os resultados da genotipagem para os polimorfismos de XPC podem ser vistos na figura 43. 

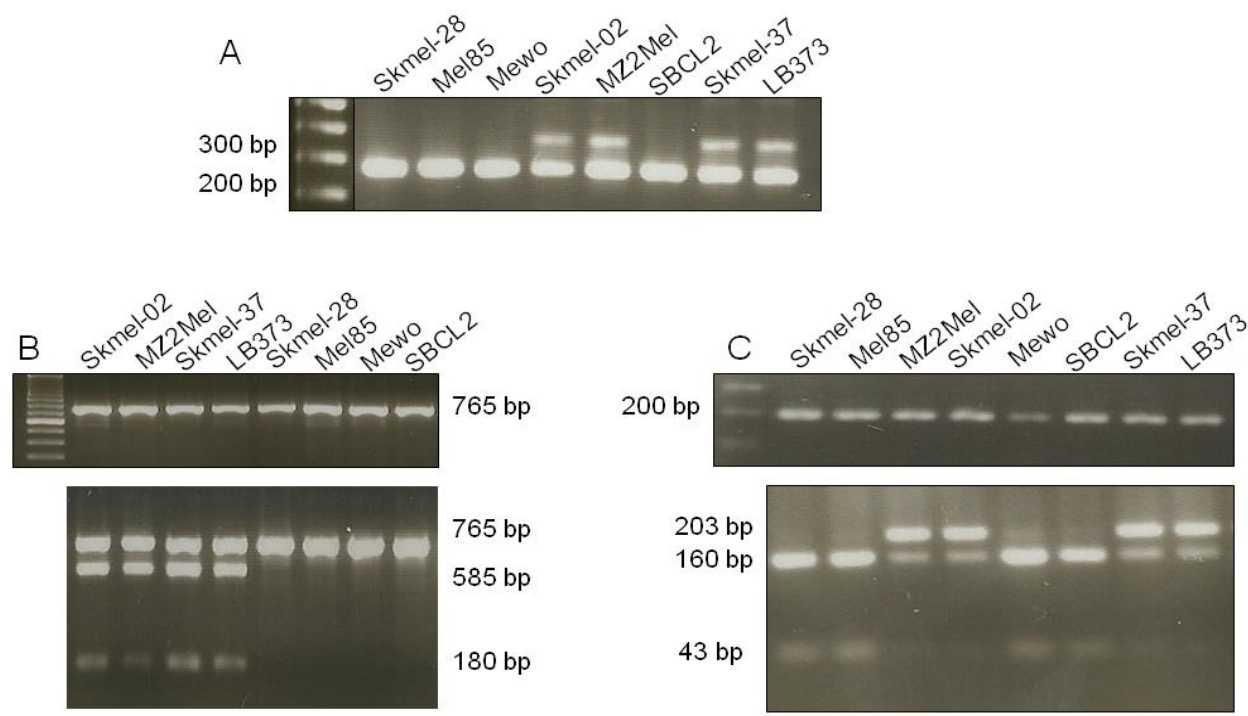

Figura 43. Genotipagem das linhagens celulares de melanoma existentes no laboratório para os polimorfismos de XPC: (A) XPC poli AT, (B) XPC K939Q, (C) XPC IV-6 C/A.

Os resultados mostram que as linhagens celulares Skmel-02, Skmel-37, LB373 e MZ2-Mel são todas heterozigotas para os polimorfismos de XPC, enquanto as demais linhagens, Skmel-28, Mel-85, Mewo e SBCL2 apresentam os genótipos selvagens para os polimorfismos de XPC. Com os resultados das genotipagens, as linhagens heterozigotas se mostram importantes para análise de expressão alélica diferencial, pois podem ser analisadas por meio de sondas específicas para Real-time PCR. A exploração de linhagens de melanoma para linhagens heterozigotas para XPC K939Q, e consequentemente para os demais polimorfismos, foi estendida para as demais linhagens adquiridas no grupo (Figura 44). Estas linhagens são: UACC-62, Skmel-05, Skmel-19, Skmel-29, Skmel-103 e Skmel-147. Resumo da genotipagem dos polimorfismos de XPC esta detalhado na tabela 4 . 

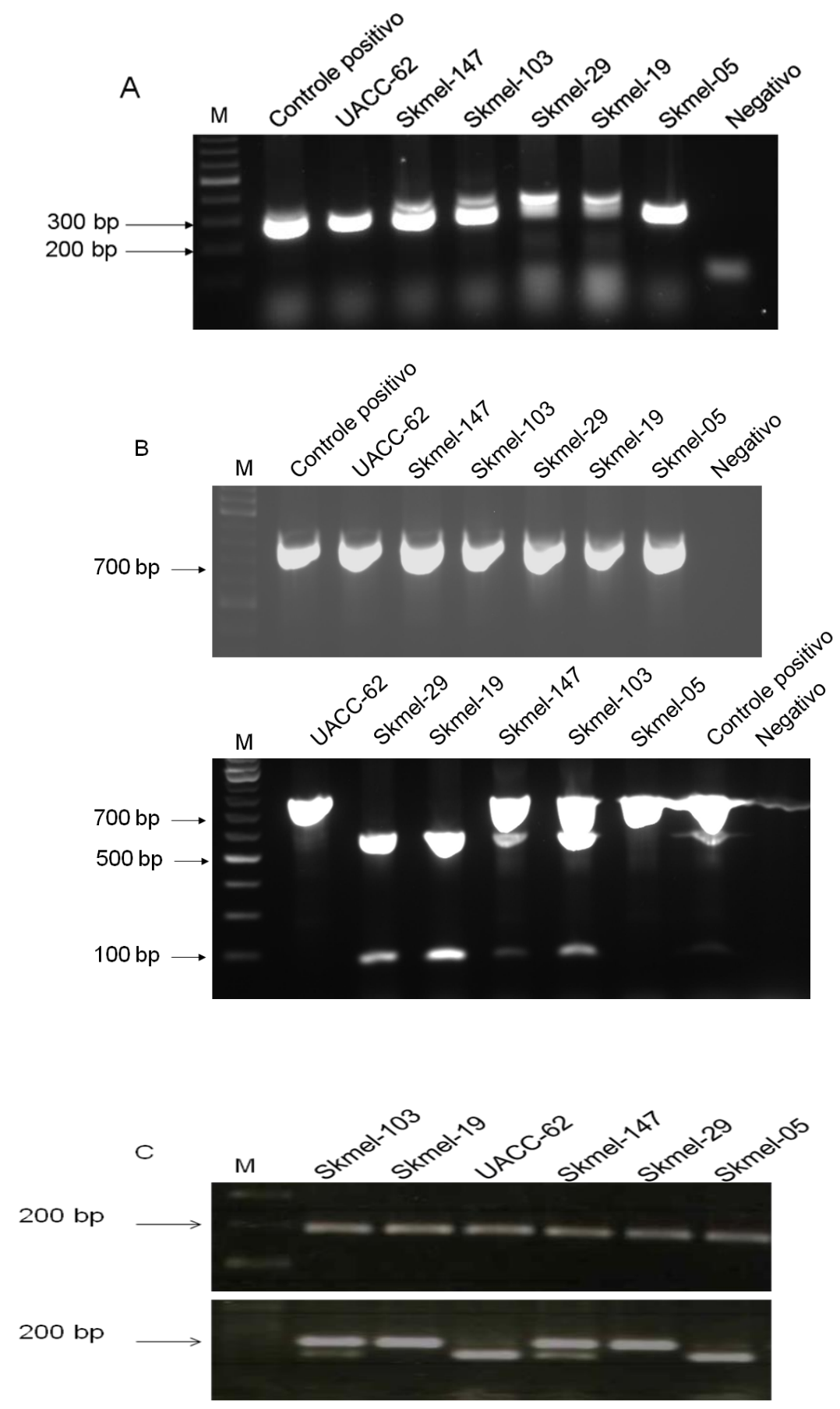

Figura 44. Genotipagens das novas linhagens celulares de melanoma existentes no laboratório para os polimorfismos de XPC: (A) XPC poli AT, (B) XPC K939Q, (C) XPC IV-6 C/A. 
Tabela 5. Resumo das genotipagens dos polimorfismos de $X P C$ nas linhagens de melanoma.

\begin{tabular}{|c|c|c|c|}
\hline & XPC poli AT & XPC IV -6 C/A & XPC K939Q \\
\hline Skmel-02 & Heterozigoto & CA & KQ \\
\hline Skmel-28 & Selvagem & CC & KK \\
\hline Skmel-37 & Heterozigoto & CA & KQ \\
\hline Mel85 & Selvagem & CC & KK \\
\hline LB373 & Heterozigoto & CA & KQ \\
\hline Mewo & Selvagem & CC & KK \\
\hline SBCL2 & Selvagem & CC & KK \\
\hline MZ2Mel & Heterozigoto & CA & KQ \\
\hline UACC-62 & Selvagem & CC & KK \\
\hline Skmel-05 & Selvagem & CC & KK \\
\hline Skmel-19 & Homozigoto & AA & QQ \\
\hline Skmel-29 & Homozigoto & AA & QQ \\
\hline Skmel-147 & Heterozigoto & CA & KQ \\
\hline & & & CA \\
\hline
\end{tabular}

4.3.3 Padronização das metodologias usadas para quantificação alelo-específica de XPC K939Q

\section{Tratamento com DNase I}

O ensaio Taqman que seria utilizado para avaliação da expressão aleloespecifica de XPC K939Q foi originalmente desenvolvida para genotipagem do polimorfismo em ensaios usando DNA, desta maneira os primers usados para amplificação seriam próprios para DNA. Além disso, o exon 15 onde se encontra o polimorfismo tem grande extensão (216 bp mais a região 3’UTR de $600 \mathrm{bp}$ )(Khan et al., 2002), impossibilitando assim o desenho de primers para usar em cDNA. 
Assim, para realizarmos a quantificação da expressão alelo-especifica houve a necessidade de se tratar o RNA extraído com DNase com o intuito de se eliminar qualquer resíduo de DNA contaminante que poderia vir a alterar a confiabilidade dos resultados. Primeiramente, houve a necessidade de verificar se havia DNA contaminante nas amostras de RNA extraídas por metodologia de TRIZOL. Para tal, usaram-se primers de amplificação de $X P C$, desenhados para se ligarem a regiões intrônicas (mais especificamente, os primers usados para genotipagem de XPC poli AT).

Para averiguação da possível contaminação de DNA em amostras de RNA, as amostras de um ensaio completo com exposição à UVB foram amplificadas para XPC poli AT. O resultado da amplificação pode ser visto na figura 45A. O resultado demonstra claramente a presença de DNA contaminante durante a extração de RNA pela metodologia do TRIZOL, confirmando assim a necessidade do tratamento de DNA para as amostras oriundas da extração de RNA.

Após metodologia de tratamento com DNase I, a qual necessitou de padronização, foi possível eliminar a presença de DNA contaminante das amostras, conforme pode ser visto no produto de amplificação exemplificado na figura 45B. Uma vez padronizada a eliminação de DNA contaminante, o RNA resultante pode ser convertido em cDNA para quantificação alelo-específica. 


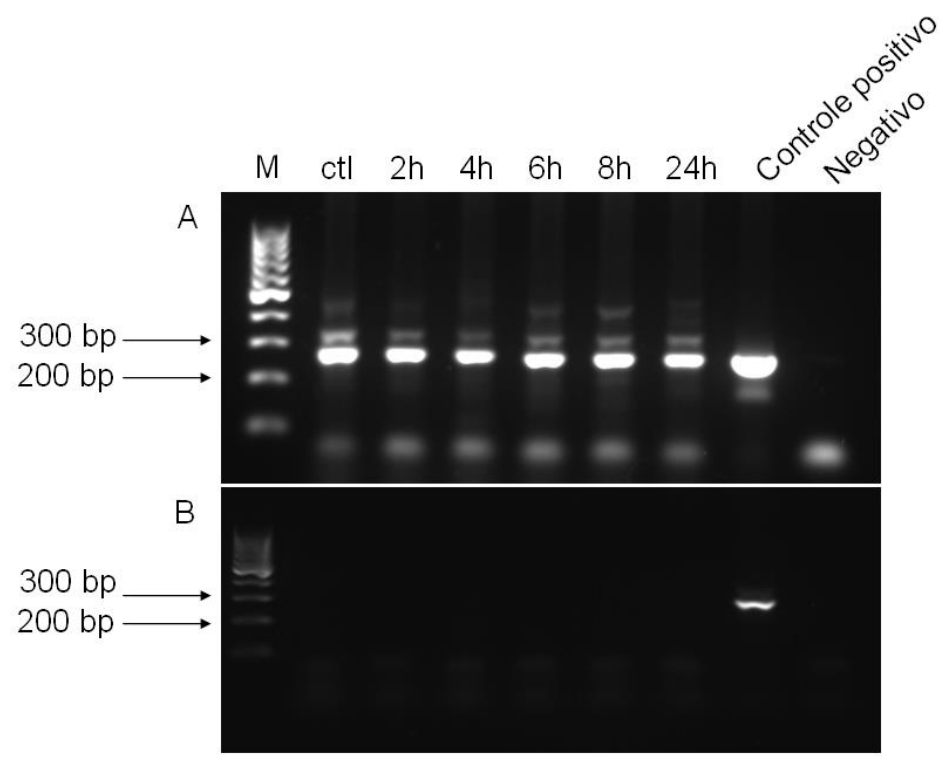

Figura 45. Amplificação de DNA contaminante em amostras de RNA extraído do ensaio para quantificação alelo-específica de XPC. (A) amplificação em amostras originais de extração. (B) amplificação após tratamento com DNase I.

\section{Teste de especificidade das sondas Taqman}

O próximo passo para garantir a sensibilidade do ensaio de expressão alelo específico seria de testar uma possível reação cruzada entre as sondas, podendo assim levar a uma interpretação errada do sinal envolvido na amplificação. Para testar a possibilidade de reação cruzada entre sondas, imaginou-se verificar a veracidade de identificação de genótipos através do ensaio Taqman em amostras genotipadas inicialmente por PCR. Optou-se por genotipar as amostras para esta finalidade usando os primers para o polimorfismo XPC poli AT (descrito na tabela 1). Em um banco de amostras de DNA de indivíduos saudáveis, procurou-se identificar o genótipo destas amostras (figura 46). 


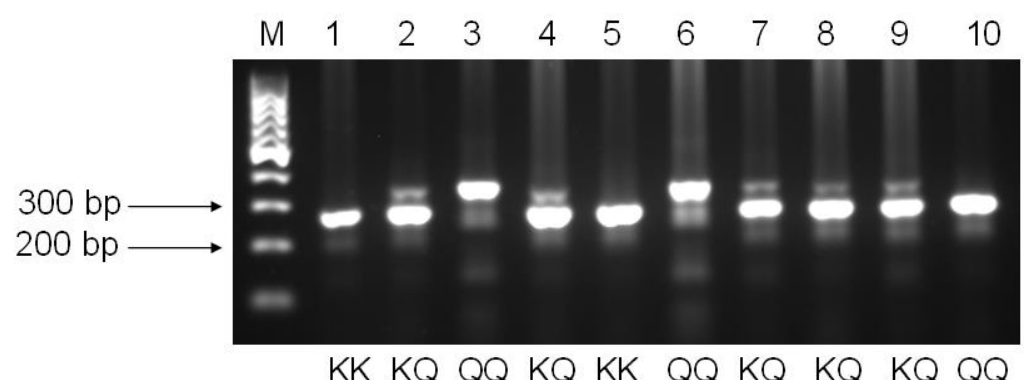

Figura 46. Genotipagem de amostras do banco de DNA para posterior teste de reação cruzada.

Com a identificação de genótipo de algumas amostras do banco de DNA disponível, o próximo passo foi testar a possível reação cruzada entre as sondas. Para tal, ensaio Taqman foi realizado utilizando-se duas amostras de cada genótipo (KK, KQ e QQ) e analisando-se a possibilidade de reação cruzada entre as sondas. O resultado do plot de genotipagem pode ser visto na figura 47. Em um primeiro teste, a utilização das sondas de genotipagem resultou na confirmação dos genótipos previamente identificados por PCR, ou seja, as amostras de genótipo KK vistas por PCR também foram confirmadas por Taqman, assim como as amostras de genótipo KQ e QQ.

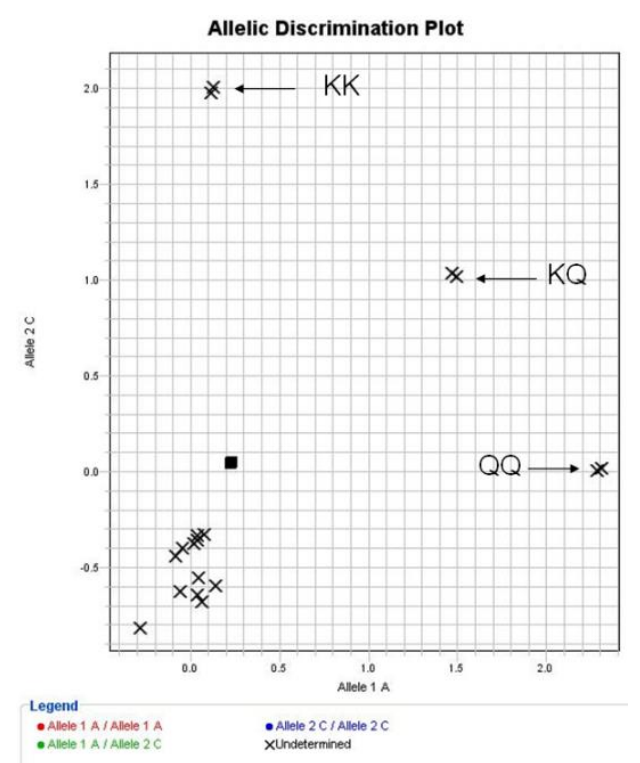

Figura 47. Plot de identificação de genótipos por Taqman. 
Para uma análise mais detalhada da amplificação das amostras, atentou-se também para os amplifications e multicomponent plots das amplificações (figura 48).

Os resultados vistos demonstram bem a especificidade das sondas utilizadas. Isto porque, nas amostras de genótipo KK, o amplification plot demonstrou apenas uma curva de amplificação (do alelo $\mathrm{K}$ ), enquanto no multicomponent plot, apenas um componente (verde) apresenta aumento na intensidade de fluorescência, enquanto o componente azul (representando o alelo Q) não apresenta mudança significativa da intensidade de fluorescência ao longo do processo de amplificação. Já nas amostras heterozigotas, há o aumento de intensidade de fluorescência nos dois fluoróforos usados (FAM e VIC, respectivamente alelos Q e K) e nas amostras de genótipo QQ, apenas o fluoróforo correspondente demonstrou aumento da intensidade de fluorescência. Tomando em conta os resultados, acredita-se que as sondas específicas para cada alelo, poderiam ser usadas para quantificação de expressão alelo-específica. 

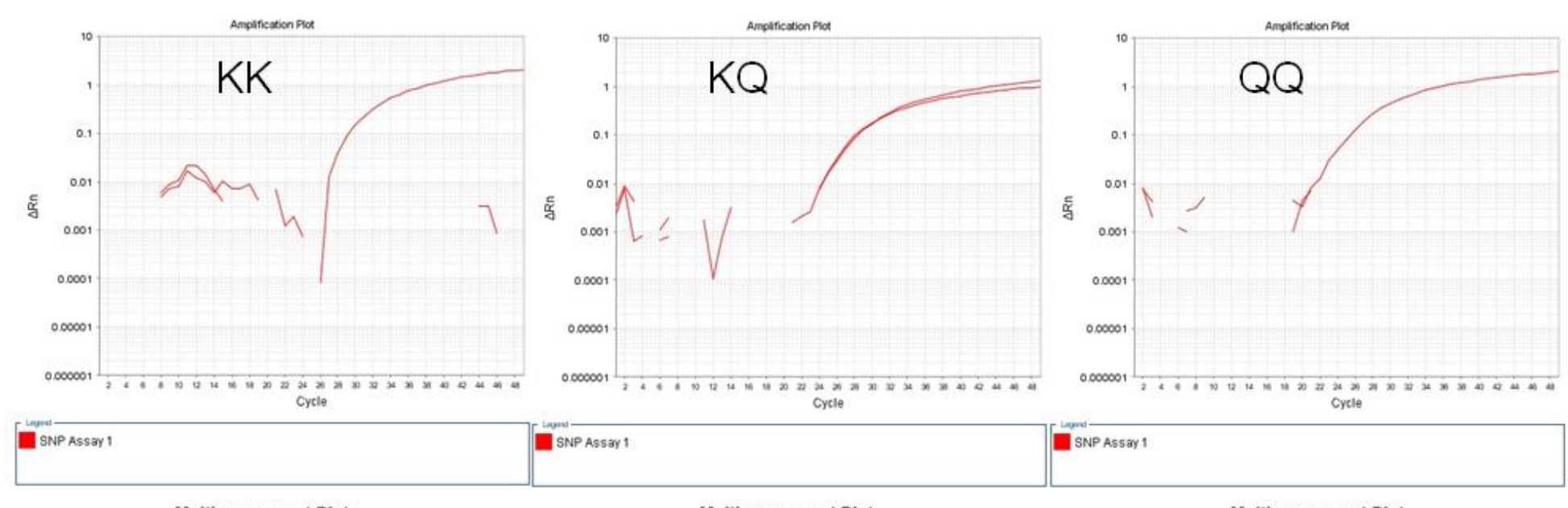

$$
\text { SNPAssay } 1
$$

ENP Assay 1
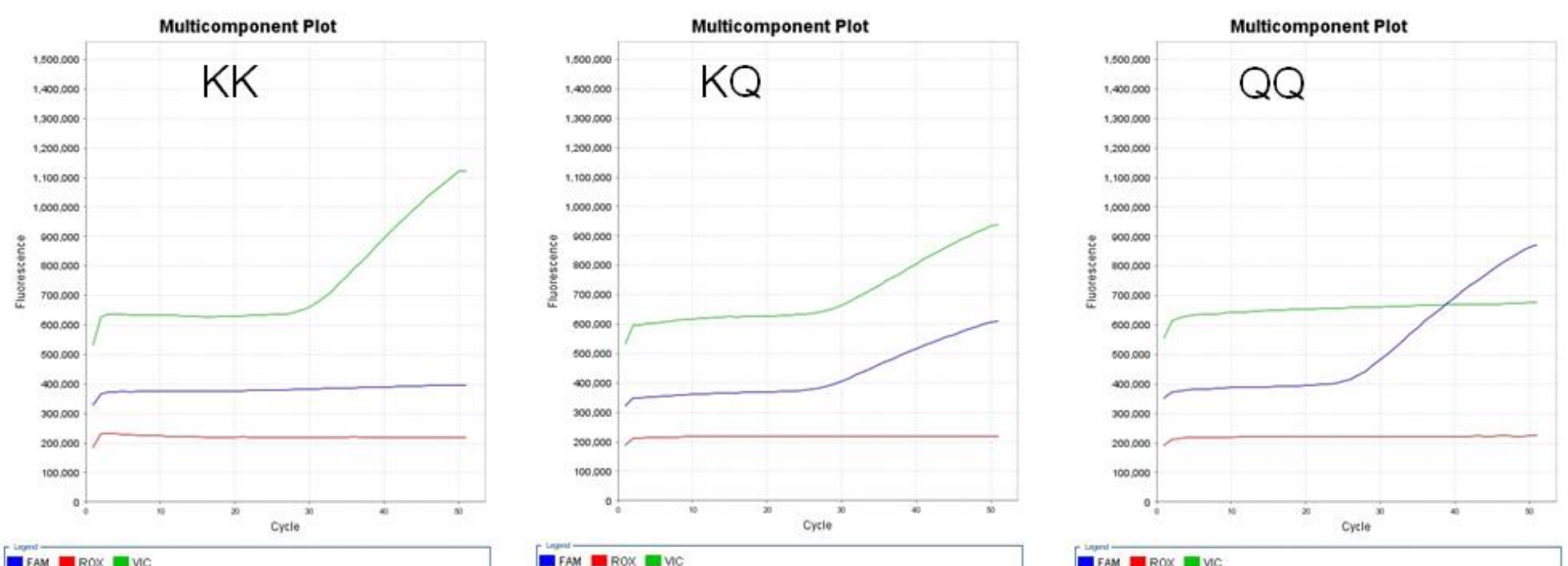

-

[ FAM

-

Figura 48. Amplification e Multicomponent plots a partir da amplificação de amostras de genótipo conhecido através do ensaio Taqman. 


\section{Construção da curva padrão}

Conforme descrito na seção de Materiais \& Métodos, houve a necessidade de se criar uma curva padrão de concentração conhecida dos alelos $\mathrm{K}$ e Q para referência no cálculo da possível diferença alelo-específica. Esta curva foi criada através de diluições diferentes de DNA homozigoto para os alelos KK com DNA homozigoto para os alelos QQ nas proporções (KK/QQ) de 4:1, 3:1, 2:1, 1:1, 1:2, 1:3 e 1:4. Uma vez criada tais diluições (todas com concentração de $50 \mathrm{ng} / \mu \mathrm{l}$ ), foi realizado o ensaio Taqman para confirmação da utilidade da curva. Os resultados da amplificação (amplification plot) de cada uma das diluições podem ser observados na figura 49. Nas figuras de cada plot, é possível observar a diferença de amplificação de cada alelo em decorrência da diluição previamente estabelecida, onde a separação das curvas obedece a expectativa de cada tipo de diluição feita.
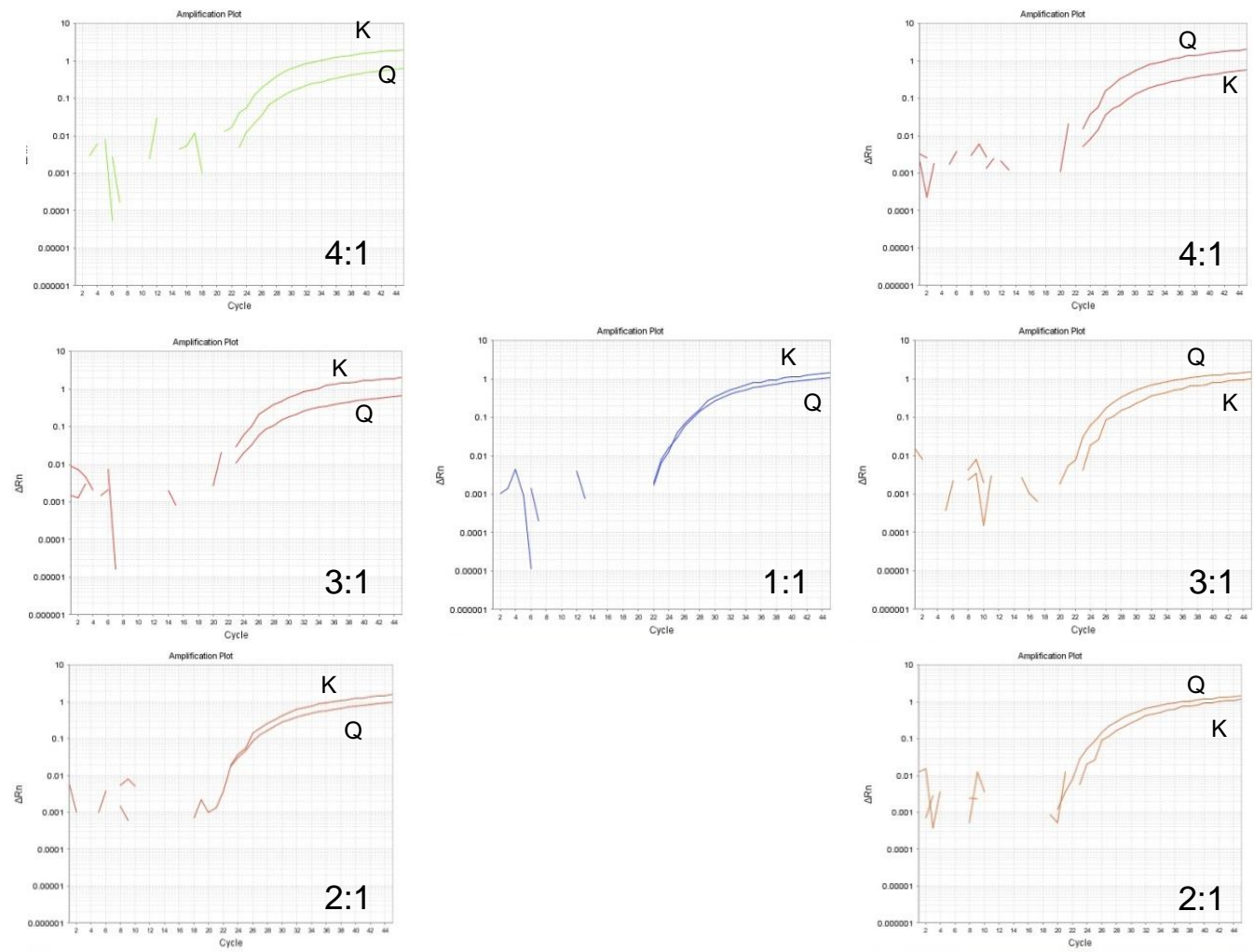

Figura 49. Amplification plots para a curva de amplificação da curva padrão. 
Uma vez obtida a curva padrão para referência, os valores obtidos da amplificação foram plotados em gráfico para averiguação dos resultados, no intuito de verificar se a curva padrão serviria de fato para base de cálculo para a expressão alelo-específica. Um exemplo dos dados plotados em gráficos pode ser visto na figura 50

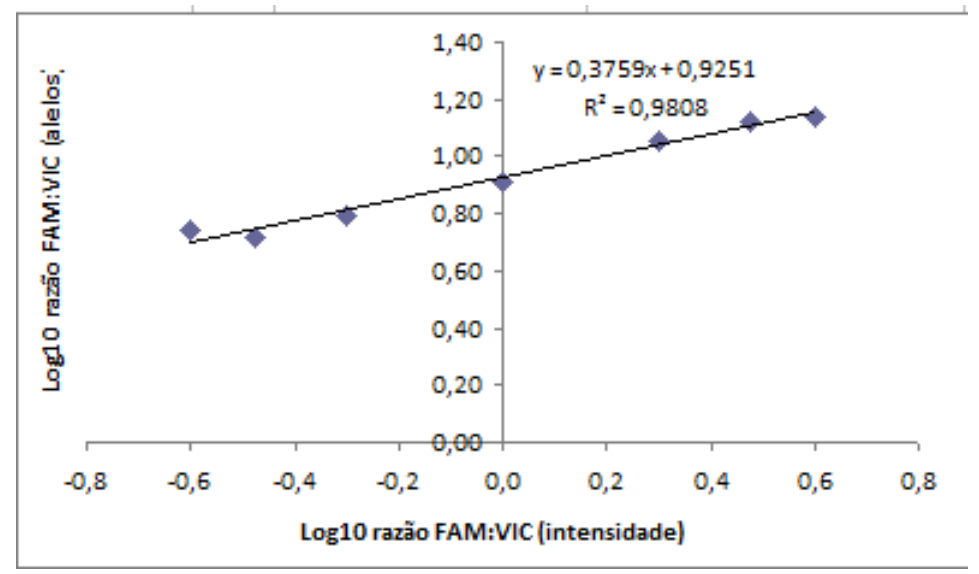

Figura 50. Plotagem dos dados da curva padrão.

O resultado da plotagem dos dados da curva padrão pareceram adequados, uma vez que o valor $\mathrm{R}^{2}$ apresentou valor de correlação de 0.98 , valor adequado para utilização de curvas padrão.

\subsubsection{Expressão de XPC e expressão alelo-específica de XPC K939Q}

Com os ensaios de padronização da metodologia de expressão aleloespecífica, o procedimento a seguir foi então a quantificação. Para a análise da expressão alelo-específica, nós optamos por fazer uma cinética de expressão de XPC após a exposição à UVB. Uma vez que a expressão de XPC é estimulada por lesões no DNA, nos poderíamos "monitorar" sua expressão ao longo do tempo após lesões 
no DNA, como por exemplo, lesões causadas por UVB. Neste sentido, poderíamos não só apenas reconhecer o padrão de expressão total de XPC como também sua expressão alelo específica, podendo correlacioná-los. A expressão total e aleloespecífica foi medida nos tempos de $0,2,4,6,8$ e 24 h após exposição à UVB (120 $\mathrm{J} / \mathrm{m}^{2}$ ). A análise das expressões de XPC para todas as cinco linhagens heterozigotas para K939Q, bem como os amplification plots de cada ponto da expressão são mostrados nas figuras abaixo. 
A
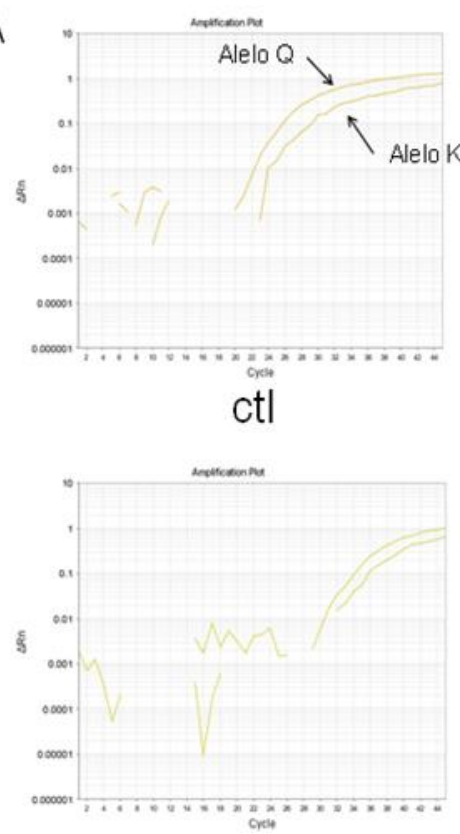

$6 h$

$\mathrm{B}$

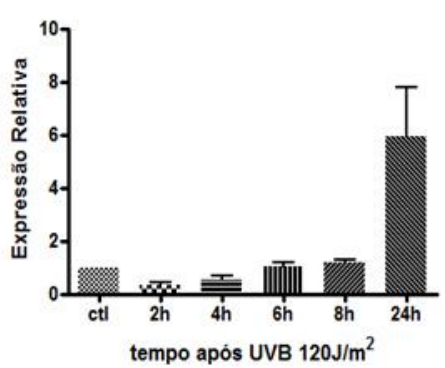

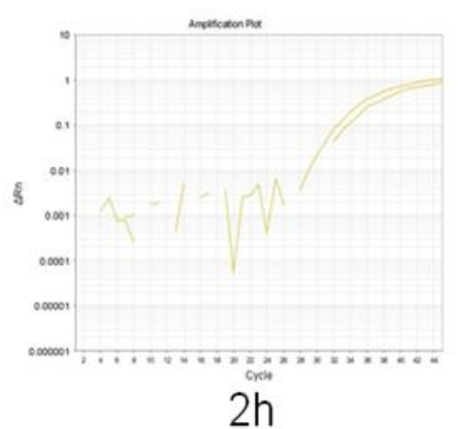
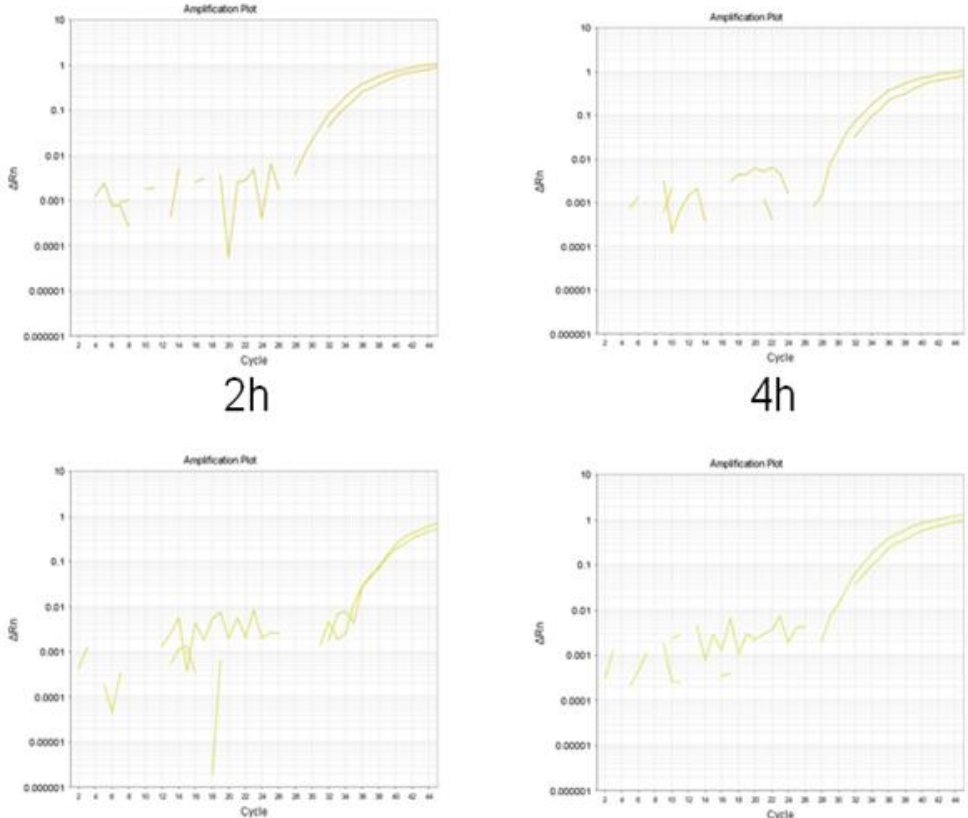

$8 \mathrm{~h}$

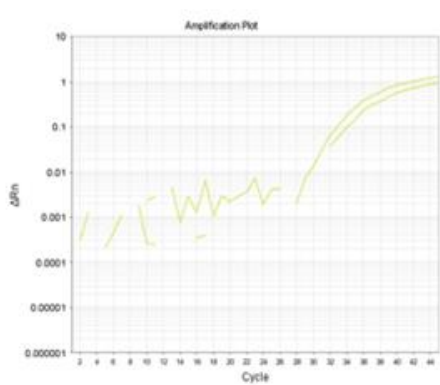

$24 \mathrm{~h}$

\section{C}

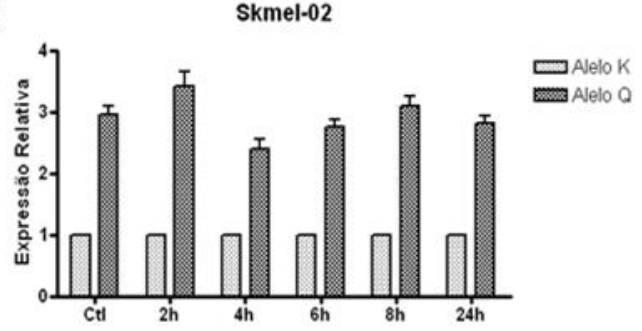

Figura 51. Análise de expressão de XPC e expressão alelo-específico de XPC K939Q em Skmel-02. (A) Amplification plots para expressão alelo-específica nos pontos analisados. (B) Expressão total de XPC. (C) Expressão alelo-especifica de XPC K939Q. Gráficos demonstram média e erro padrão de três experimentos independentes. 

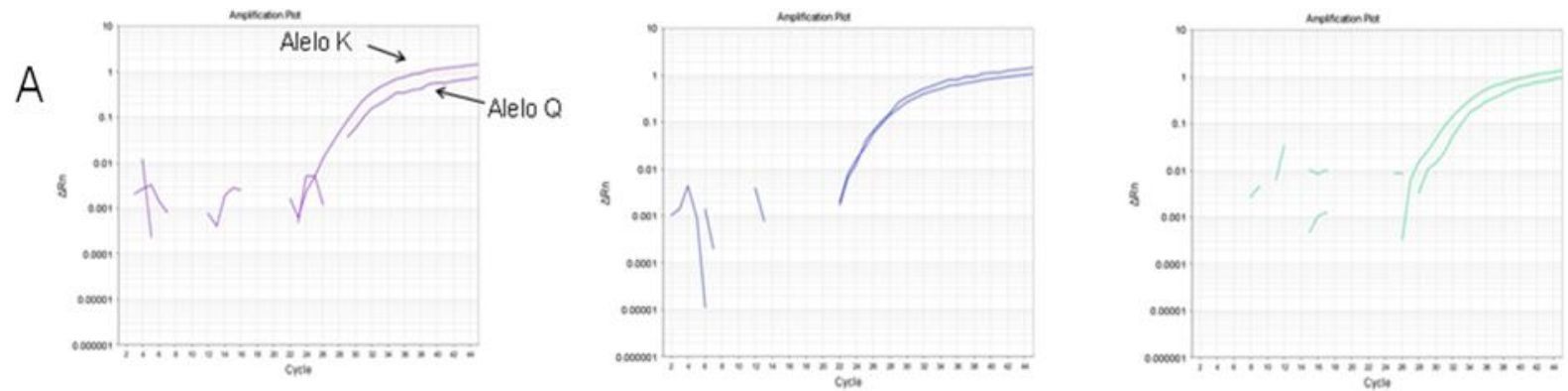

ctl
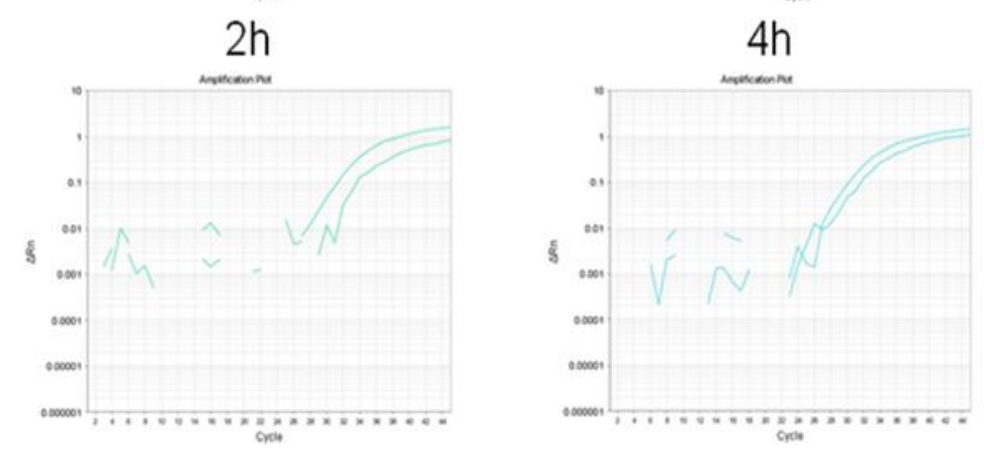

$6 \mathrm{~h}$

$8 \mathrm{~h}$

$24 \mathrm{~h}$

B

Skmel-37

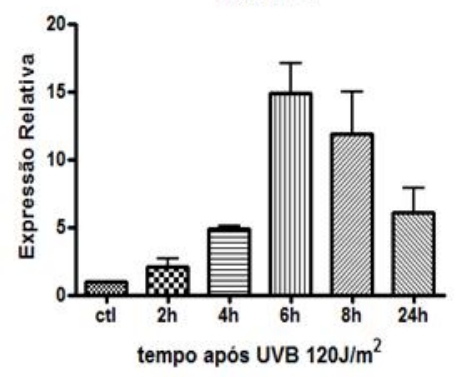

C

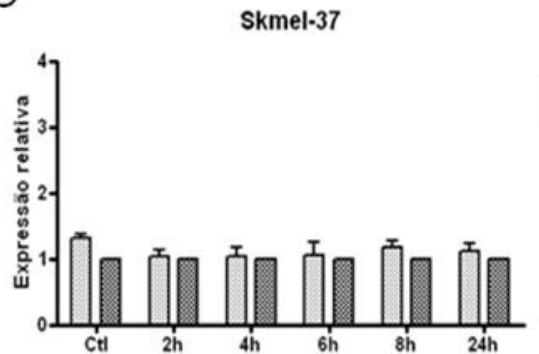

$\square$ A velo K

Alelo O

Figura 52. Análise de expressão de XPC e expressão alelo-específico de XPC K939Q em Skmel-37. (A) Amplification plots para expressão alelo-específica nos pontos analisados. (B) Expressão total de XPC. (C) Expressão alelo-especifica de XPC K939Q. Gráficos demonstram média e erro padrão de três experimentos independentes. 


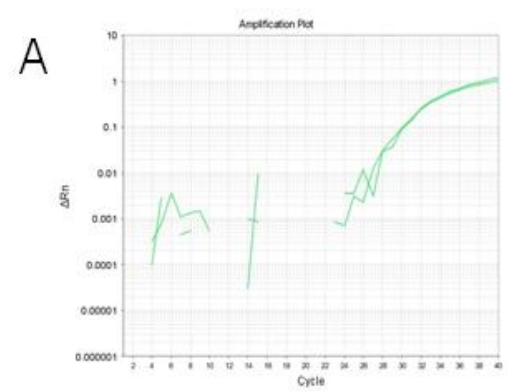

ctl

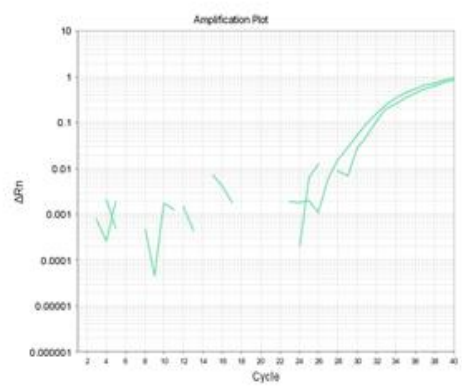

$6 \mathrm{~h}$

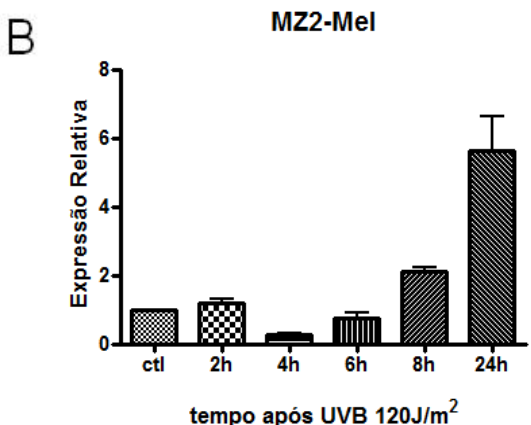

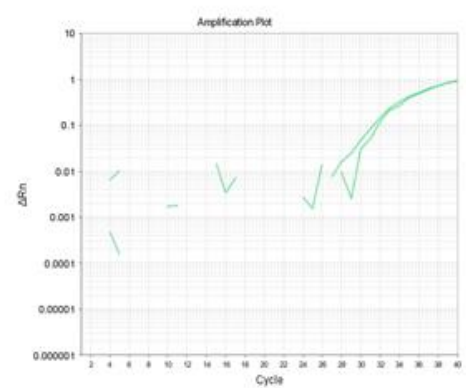

$2 \mathrm{~h}$

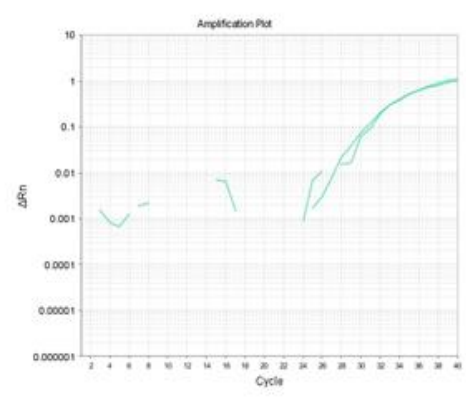

$8 \mathrm{~h}$

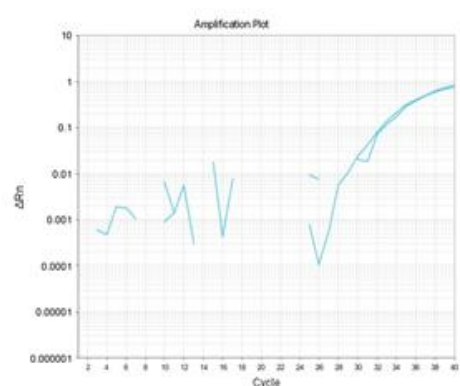

$4 \mathrm{~h}$

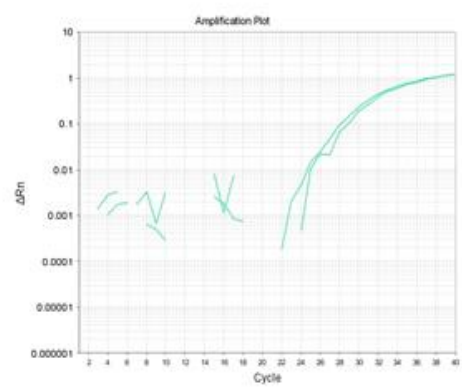

$24 \mathrm{~h}$

C

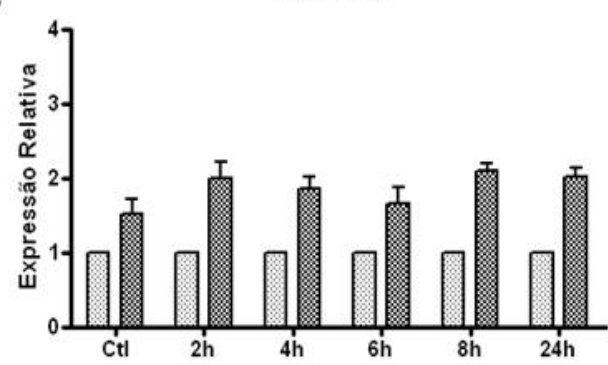

Figura 53. Análise de expressão de XPC e expressão alelo-específico de XPC K939Q em MZ2-Mel. (A) Amplification plots para expressão alelo-específica nos pontos analisados. (B) Expressão total de XPC. (C) Expressão alelo-especifica de XPC K939Q. Gráficos demonstram média e erro padrão de três experimentos independentes. 

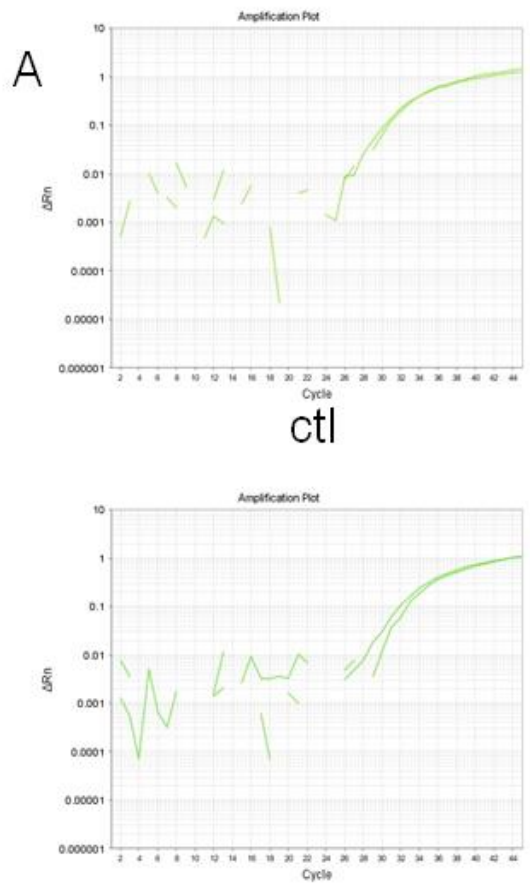

$6 \mathrm{~h}$
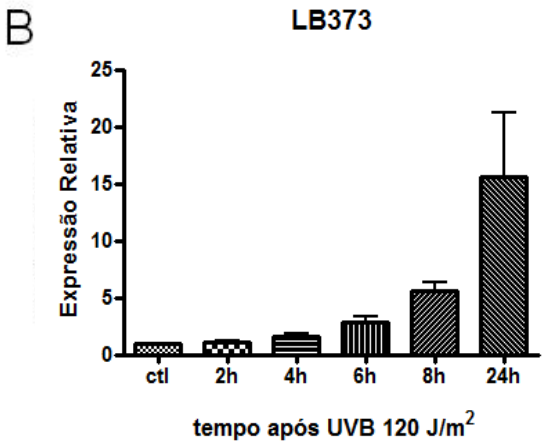

C

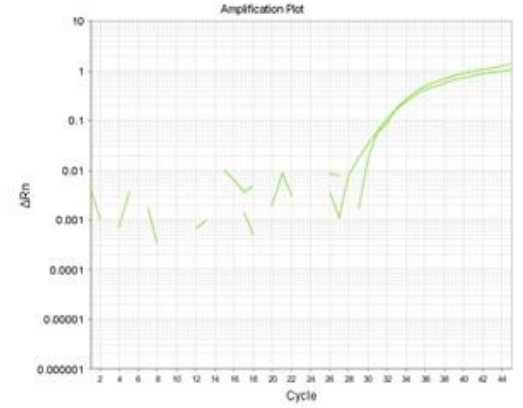

$2 \mathrm{~h}$
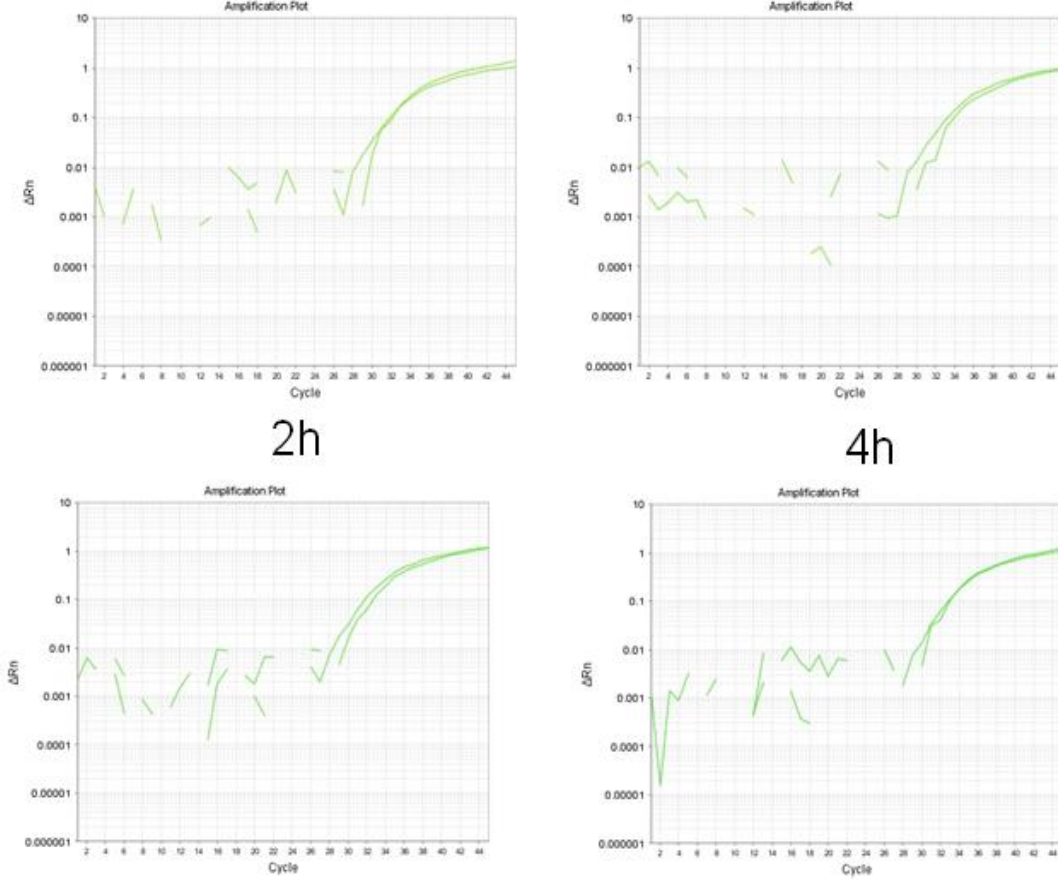

$8 \mathrm{~h}$
$4 \mathrm{~h}$

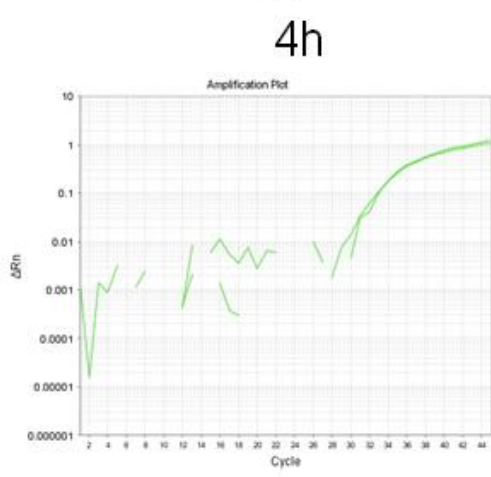

$24 h$

LB373

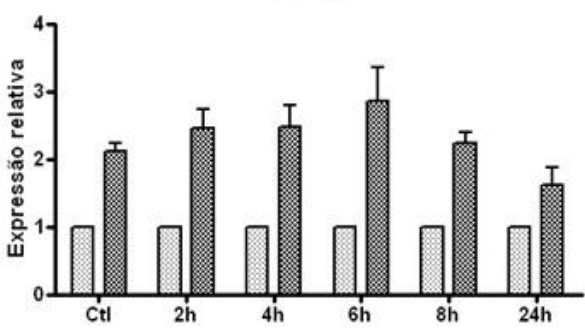

Alelo K

Figura 54. Análise de expressão de XPC e expressão alelo-específico de XPC K939Q em LB-373. (A) Amplification plots para expressão alelo-específica nos pontos analisados. (B) Expressão total de XPC. (C) Expressão alelo-especifica de XPC K939Q. Gráficos demonstram média e erro padrão de três experimentos independentes. 


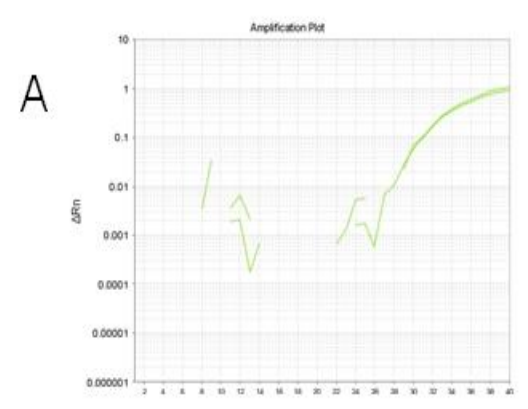

ctl

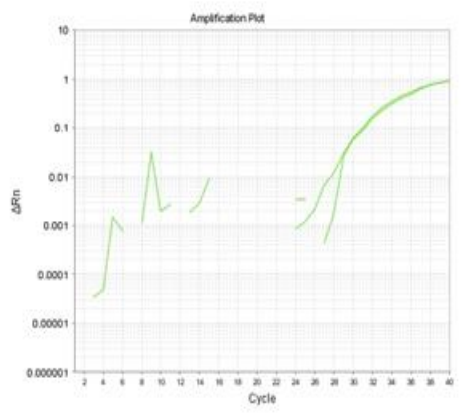

$6 \mathrm{~h}$

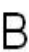

$\mathrm{B}$

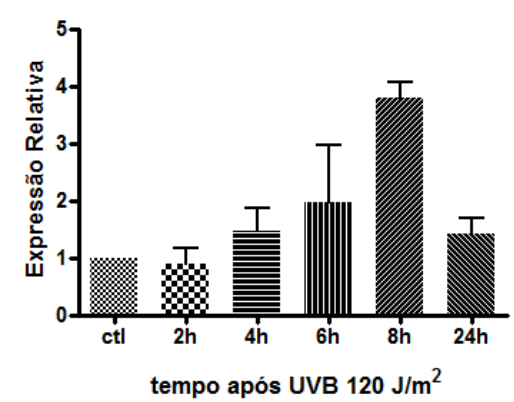

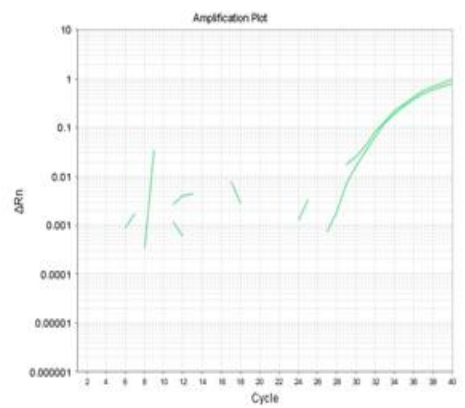

$2 \mathrm{~h}$

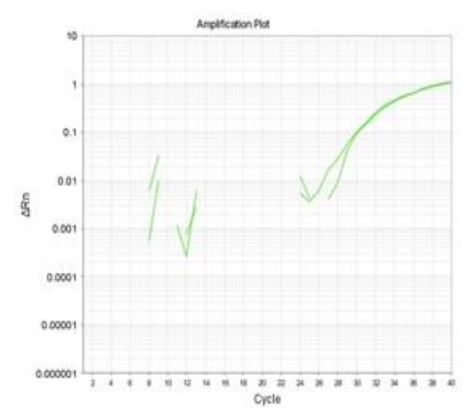

$8 \mathrm{~h}$
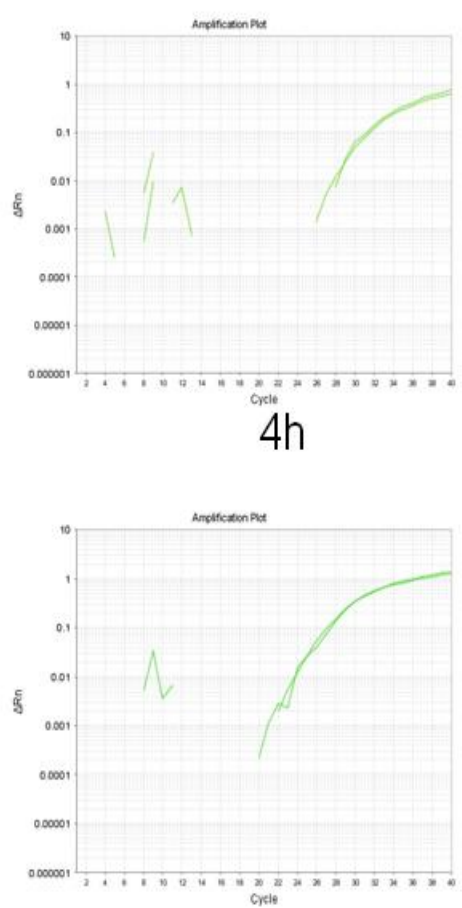

$24 \mathrm{~h}$

C
Skmel-147

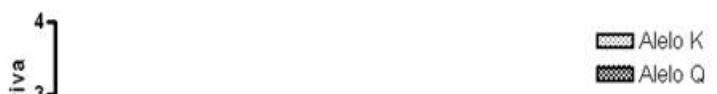

Figura 55. Análise de expressão de XPC e expressão alelo-específico de XPC K939Q em Skmel-147. (A) Amplification plots para expressão alelo-específica nos pontos analisados. (B) Expressão total de XPC. (C) Expressão alelo-especifica de XPC K939Q. Gráficos demonstram média e erro padrão de três experimentos independentes. 
Os resultados demonstrados para a expressão de XPC e expressão aleloespecífica apresentaram interessantes diferenças entre as linhagens. Em primeiro lugar, é possível notar que não houve um padrão comum de expressão total de XPC após irradiação com UVB. De maneira geral, todas as linhagens apresentaram aumento da expressão de XPC após irradiação com UVB. No entanto, esse aumento demonstrou pontos diferentes entre as linhagens. A expressão de XPC em Skmel-37 e Skmel-147 teve seu maior aumento em 6 e 8 h após exposição à UVB, enquanto nas linhagens LB373 e MZ2-Mel, este aumento foi mais tardio, após 8 e 24h. Já para Skmel-02, foi perceptível uma diminuição da expressão de XPC após 2 e 4h de exposição, enquanto o aumento só se deu após $24 \mathrm{~h}$, o que demonstra um processo mais tardio de expressão de XPC.

Quanto à expressão alelo-especifica, os resultados demonstraram que, exceto para Skmel-37 cuja expressão dos alelos K e Q estavam próximas, o alelo Q se mostrou mais expresso. Nas linhagens MZ2-Mel, LB-373 e Skmel-147, o alelo Q esteve mais expresso em cerca de 2x. Já na linhagem Skmel-02, o alelo Q mostrou-se cerca de 3x mais expresso que o alelo K. Os resultados da expressão total de XPC e a expressão alelo-específica não demonstraram uma clara correlação entre ambos. Além disso, não houve também uma associação entre diferenças de expressão alélica e tempo decorrido de exposição após UVB.

Como controle negativo da reação, as amostras de cada ponto e de cada linhagem após o tratamento com DNase I e antes do RNA ser convertido em cDNA também foram testadas para o metodologia Taqman. Tal iniciativa teve como objetivo confirmar que a amplificação vista nas amostras convertidas em cDNA estava relacionada realmente a presença da quantidade do mensageiro de $X P C$ e não de 
eventual DNA contaminante, restante da extração do RNA e do tratamento prévio com DNase I. Os resultados podem ser visto nas figuras 19 e 20. Em geral, nas amostras negativas não houve amplificação de XPC. Para aquelas amostras onde houve algum tipo de amplificação, estas se mostraram mais tardias do que as amostras "positivas" (cDNA convertido), sugerindo que esta amplificação tardia não interferiu na avaliação da expressão alelo-especifica da amostra. 
Skmel-147

LB-373

MZ2-Mel

CtI

$2 \mathrm{~h}$
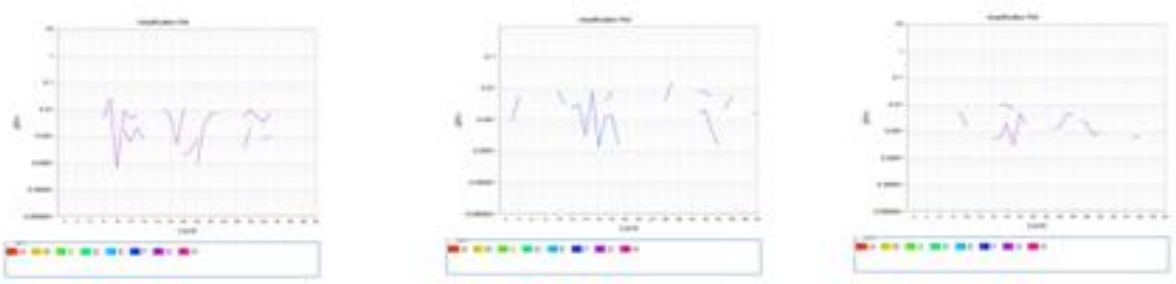

$4 \mathrm{~h}$
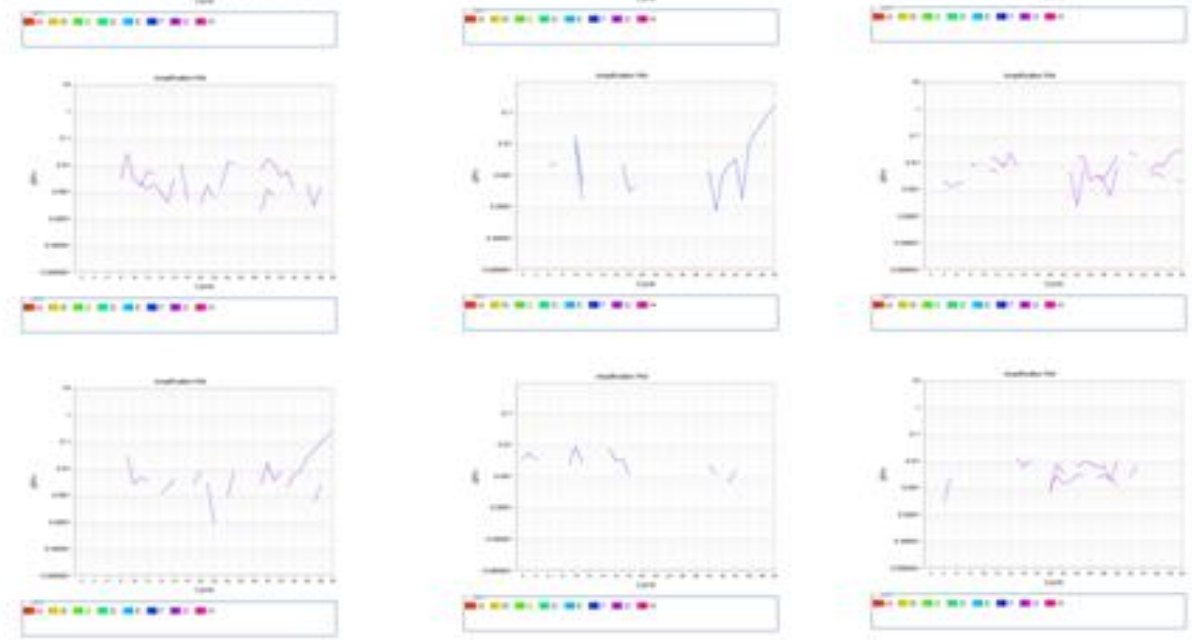

$6 \mathrm{~h}$
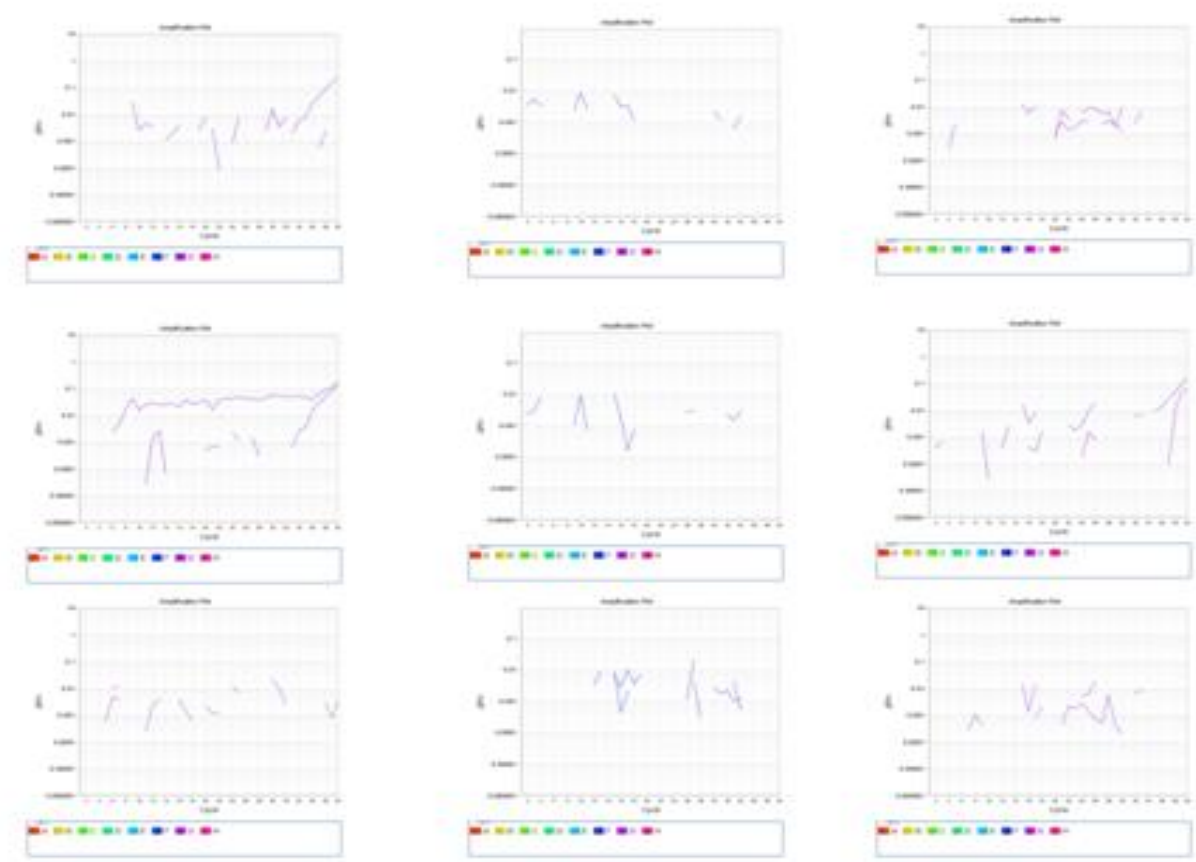

$8 \mathrm{~h}$
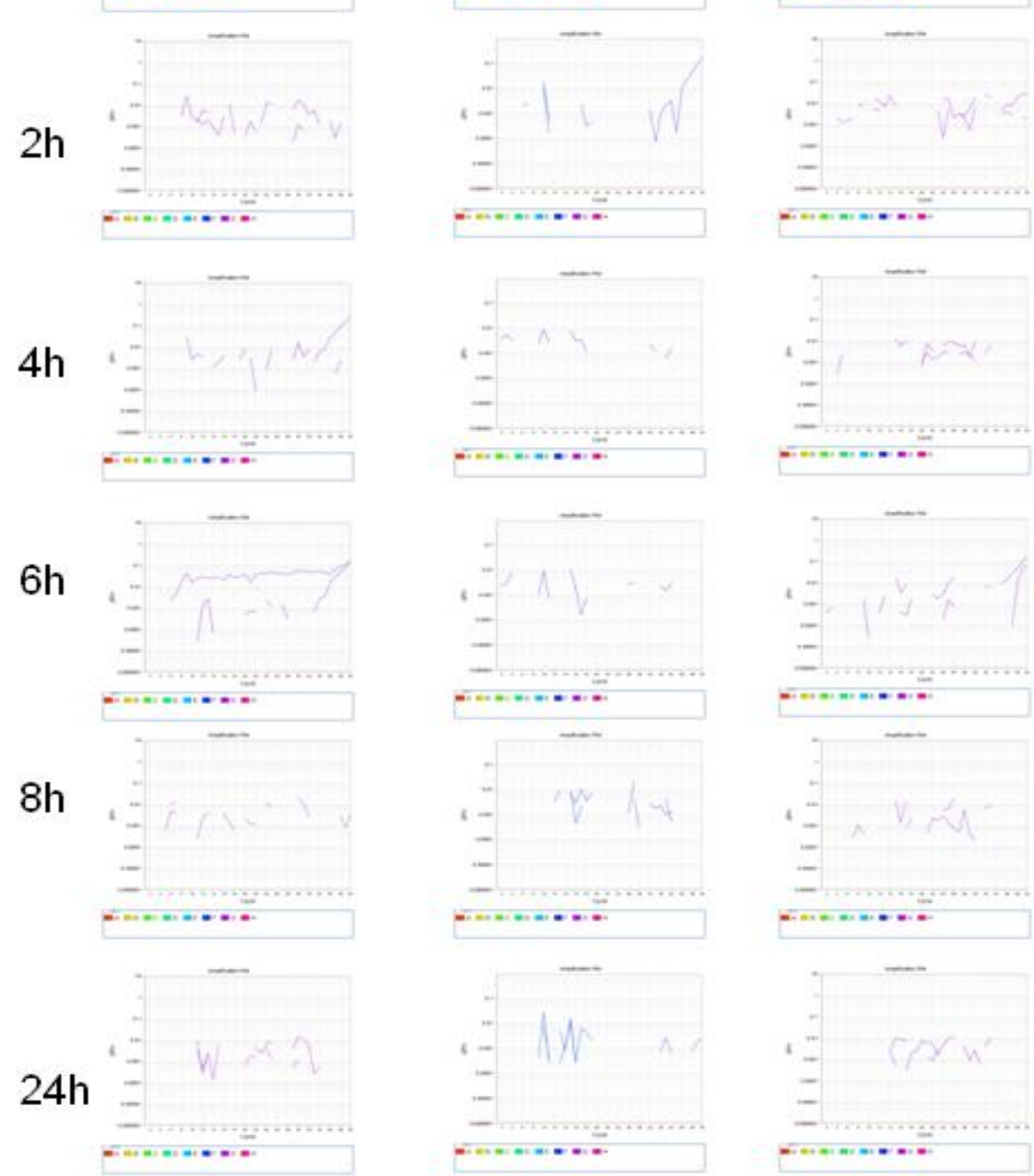

Figura 56. Controle negativos para ensaio de Taqman para K939Q. 
Skmel-02

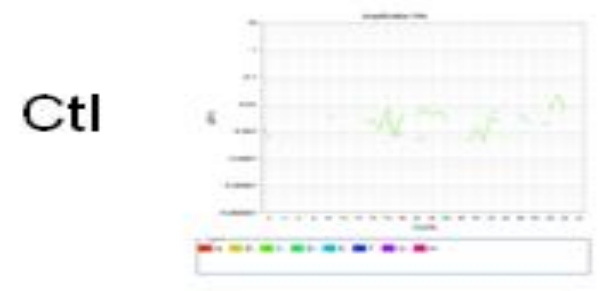

$2 \mathrm{~h}$

$4 h$

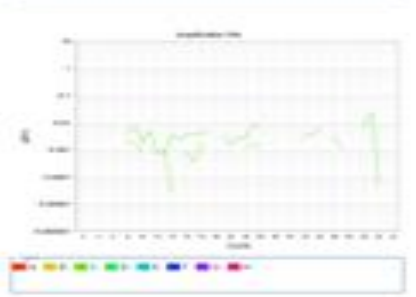

$6 \mathrm{~h}$

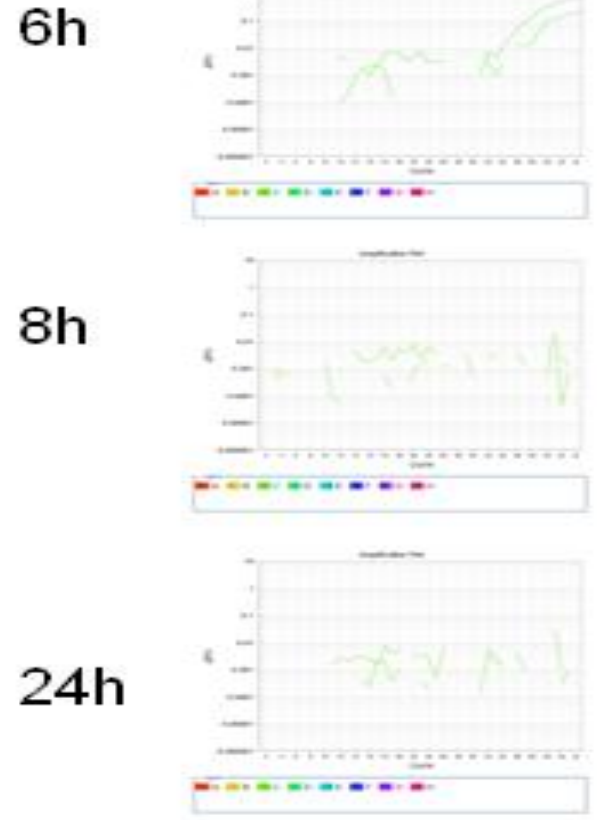

Skmel-37
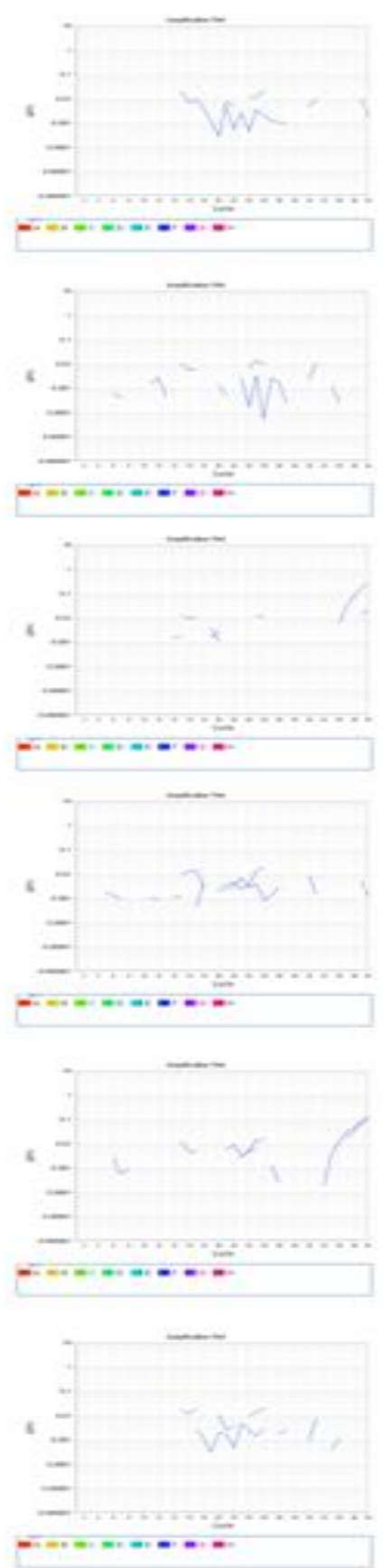

Figura 57. Controle negativos para ensaio de Taqman para K939Q. 


\subsection{Papel de p53 na resposta à Cisplatina}

\subsubsection{Sensibilidade das linhagens Skmel-28 e Skmel-37 à Cisplatina}

Para compreender melhor o possível papel do status funcional de p53 em melanomas e sua influência na resposta à cisplatina, as linhagens Skmel-28 e Skmel-37, as quais apresentam diferenças funcionais quanto à p53 (resultados observados na seção 4.1), foram testadas quanto à sensibilidade à cisplatina. Ambas as linhagens foram expostas a três diferentes concentrações de cisplatina $(6.25,12.5$ e $25 \mu \mathrm{M})$ por $24 \mathrm{~h}$. Para uma análise de resposta à cisplatina em maior tempo, as linhagens foram expostas as mesmas concentrações por $24 \mathrm{~h}$, sendo após este tempo as linhagens deixadas por mais 24h com meio de cultura livre de cisplatina (aqui chamado de pós $24 \mathrm{~h}$ de cisplatina). Após estes dois tempos de exposição, as células e o sobrenadante foram analisados para morte celular como descrito anteriormente. Os resultados podem ser vistos nas figuras $58 \mathrm{~A}$ e B.
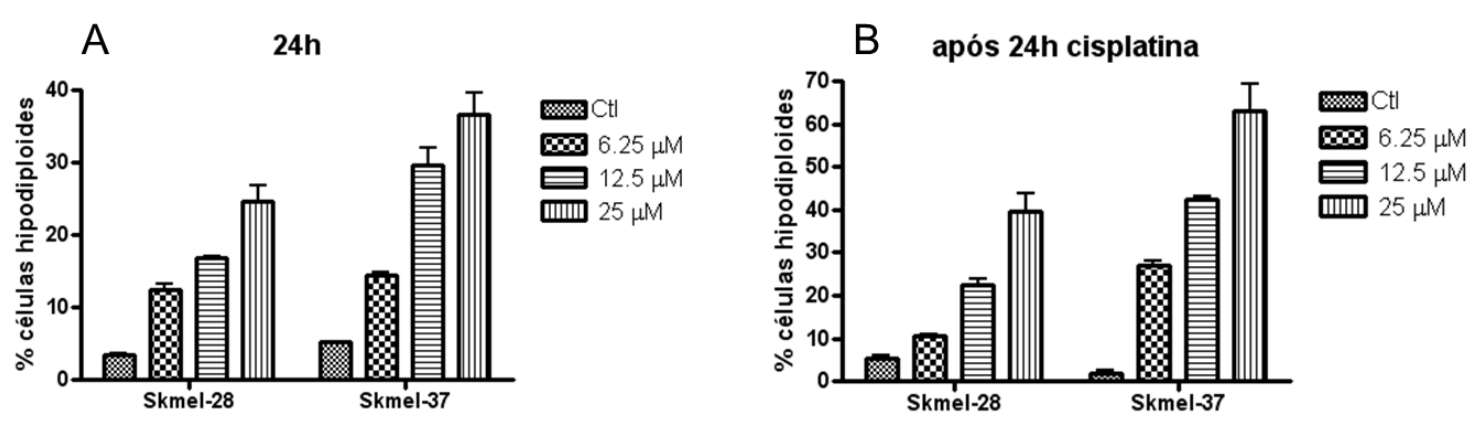

Figura 58. Sensibilidade das linhagens Skmel-28 e Skmel-37 a diferentes doses de cisplatina. (A) Sensibilidade após $24 \mathrm{~h}$ de exposição. (B) Sensibilidade após $24 \mathrm{~h}$ da exposição das primeiras $24 \mathrm{~h}$ com cisplatina. Resultados mostram média e desvio padrão de ensaio em triplicata. Ensaio representativo de triplicatas independentes.

Os resultados mostraram que a linhagem Skmel-28 se mostrou menos sensível a morte por cisplatina em ambos os tempos de exposição e concentração em comparação 
a linhagem Skmel-37, demonstrando desta maneira um fenótipo mais resistente. Esta diferença de sensibilidade entre linhagens pode ser o passo inicial para explorar fatores envolvidos com a já conhecida quimiorresistência de melanomas. Para posterior exploração dos mecanismos responsáveis por tal resistência, optou-se pela concentração de $12.5 \mu \mathrm{M}$, a qual apresentou diferenças importantes no padrão de morte, sendo seu efeito, no entanto, não tão deletério como a dose de $25 \mu \mathrm{M}$.

Para confirmar a diferença de sensibilidade à cisplatina, as linhagens também foram testadas para ensaios de sobrevivência para a formação de colônias após cisplatina. Neste ensaio, células foram plaqueadas de maneira individual, tratadas com cisplatina por $24 \mathrm{~h}$ com diferentes concentrações de cisplatina $(0.5,1$ e $5 \mu \mathrm{M})$ (neste caso, doses menores que as usadas para sensibilidade, uma vez que as células estariam individualizadas) e deixadas para formação de colônias, conforme descrito nos Materiais e Métodos. Os resultados mostrados na figura 59 demonstraram novamente que a linhagem Skmel-28 possui maior resistência à cisplatina e maior capacidade de formação de colônias.

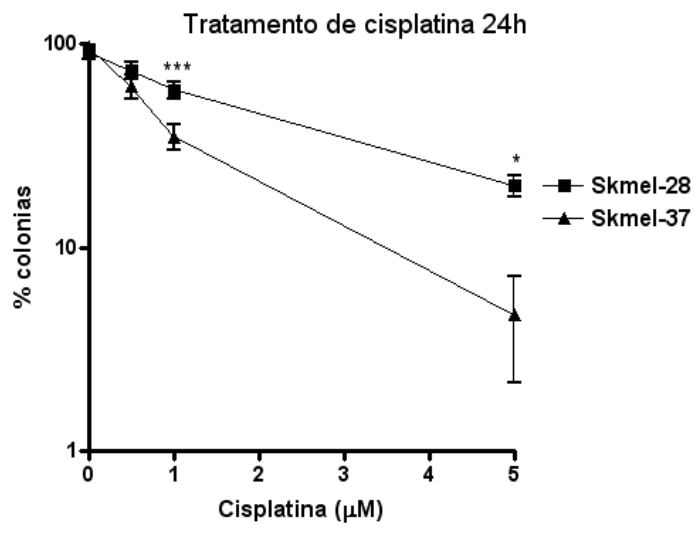

Figura 59. Ensaio clonogênico de sobrevivência. Resultados mostram média e desvio padrão de ensaio em triplicata. Ensaio representativo de triplicatas independentes. $* p<0.05 ; * * * p<0.001$. 


\subsubsection{Exploração de vias relacionadas com resistência à cisplatina}

Os resultados para sensibilidade à cisplatina demonstraram que a linhagem Skmel-28 possui um fenótipo de resistência que pode ser explorado para entender os possíveis mecanismos que possam contribuir para tal resistência. Para começar a explorar possíveis vias moleculares envolvidas com o fenótipo de resistência, optou-se inicialmente por duas importantes vias: a via de p53, já explorada na relação com resistência a UVB (seção 4.1) e também relatada como via envolvida a resistência à cisplatina em outros tumores (Ali et al., 2012), e também a via ERK, via também relacionada a resistência à cisplatina em melanomas (Mirmohammadsadegh et al., 2007).

As análises por Western blotting referentes a estas vias demonstraram que para a via de ERK, não houve alteração nos padrões de fosforilação nas duas linhagens nos tempos analisados, sugerindo pouca influência desta via na modulação da resistência nestas linhagens. Por outro lado, quanto à via de p53, na linhagem Skmel-28 tal via se mostrou não funcional após exposição à cisplatina, fato que pode ser explicado pela mutação já descrita nesta linhagem (R145L). Ao contrário, na linhagem Skmel-37 houve uma resposta positiva da via p53 tanto quanto a acumulação de p53 quanto a expressão de p21 (Figura 60). 


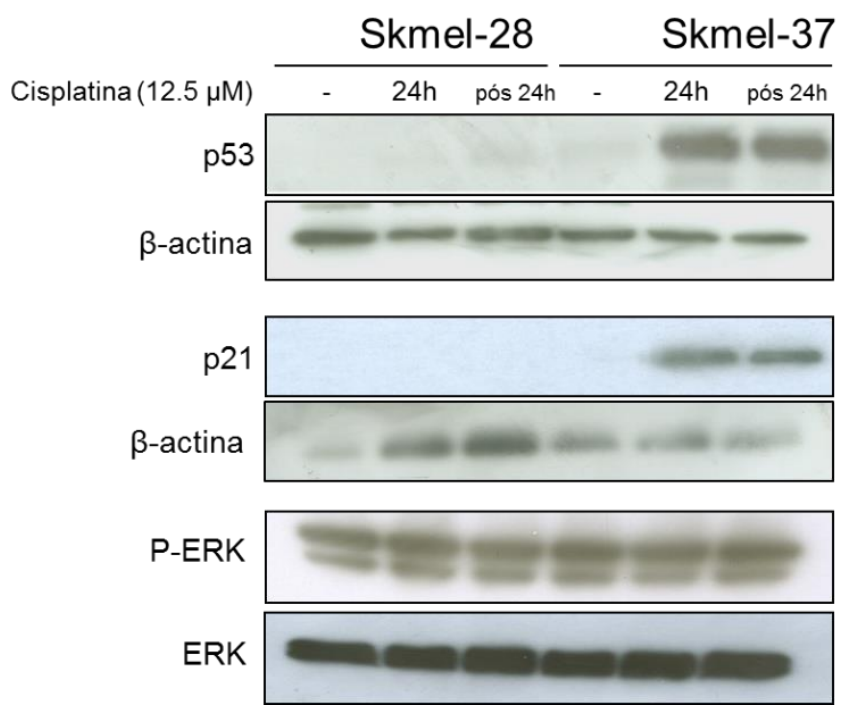

Figura 60. Western Blotting para p53, p21 e fosfo-ERK para Skmel-28 e Skmel-37 após exposição à cisplatina.

Além das vias de p53 e ERK, observamos também a possível influência de genes chaves da via NER. Para verificarmos tal influência, procurou-se analisar a expressão de XPC, uma vez que tal proteína demonstra estar sob influência transcricional de p53, além de existir um debatido na literatura quanto a sua real participação na resposta e resistência à cisplatina (Enoiu et al., 2012; Lee et al., 2014). Assim, a análise de XPC não só poderia dar maiores subsídios quanto à participação da via GGR-NER, como também suporte para a funcionalidade de p53 na resposta ao quimioterápico.

Em seguida, relacionando a atividade de reconhecimento e inicio de reparo por XPC, procurou-se analisar também a atividade de dano e reparo de lesões genômicas causadas por cisplatina através dos níveis de fosforilação da Histona H2AX bem como a expressão de ERCC1, outra proteína acessória da atividade NER (Figura 2) e que tem sido relacionada à resistência à cisplatina (Bowden, 2014). Os resultados apresentados pela figura 61 demonstram a expressão de XPC, fosfo-H2AX e ERCC1 nas linhagens analisadas após tratamento. 


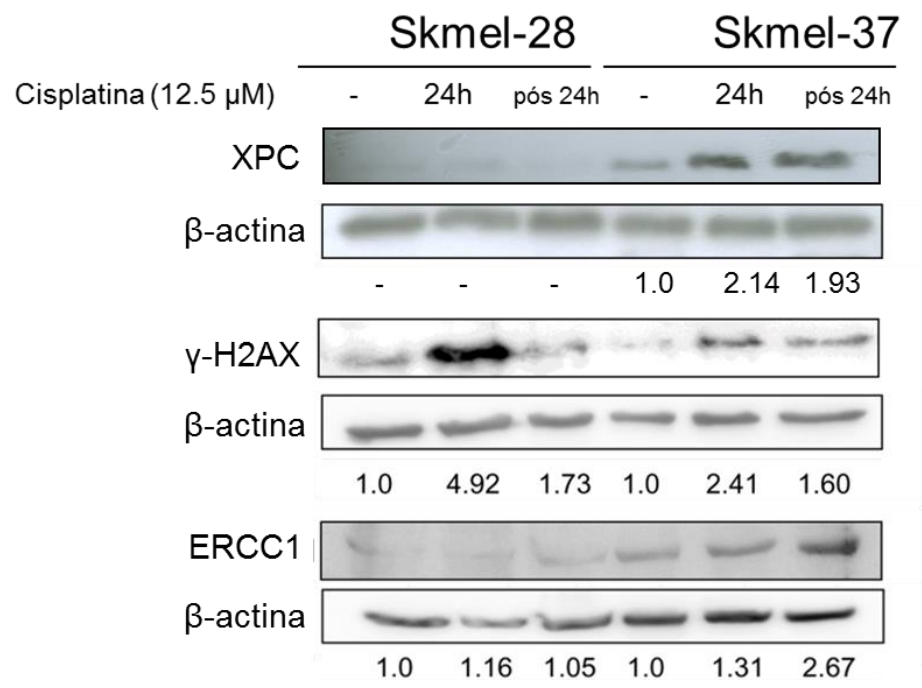

Figura 61. Western blottings para expressão de XPC, fosfo-H2AX e ERCC1.

Os resultados indicam importantes características. Primeiramente, demonstram que XPC só foi expresso em Skmel-37 conforme a exposição à cisplatina. Fato este que pode realmente demonstrar o papel da atividade p53 na expressão de XPC. Em segundo lugar, para os resultados em relação aos níveis indiretos de danos genômicos, demonstraram que os níveis de fosforilação de H2AX apresentaram maior acúmulo em Skmel-28 após tratamento com cisplatina, seguida de uma diminuição acentuada após a retirada da cisplatina, sugerindo um mecanismo de reparo eficiente. Ao contrário em Skmel-37, embora um menor acúmulo durante a exposição, tais níveis de fosforilação tiveram menor queda 24h após. Quanto à expressão de ERCC1, mesmo sendo esta proteína correlacionada com resistência, nestas duas linhagens não demonstrou relação direta.

\subsubsection{Inibição da atividade de p53 por pifithrin- $\alpha$}

Uma das vias analisadas que poderia estar relacionada à resistência é a via de p53. Os resultados indicaram que Skmel-28, mais resistente, apresentava deficiência na 
via de p53, conforme visto pelos resultados de western blotting da própria p53 e de p21, ao contrário de Skmel-37. Para confirmar o real impacto da via de p53 optou-se por usar o inibidor farmacológico de p53, pifithrin- $\alpha$, e verificar seu efeito na resposta à cisplatina. Desta maneira, as linhagens foram tratadas com pifithrin- $\alpha$ e cisplatina, sendo o padrão de morte celular observado 24 h após as $24 \mathrm{~h}$ iniciais de exposição à cisplatina. Os resultados (Figura 62) mostraram que para Skmel-28 não houve mudança na resposta à cisplatina, resultado que pode ser justificado pela ausência de atividade de p53 nesta linhagem. Já para Skmel-37 é possível verificar que o uso de inibidor de p53 levou a uma menor taxa de morte celular, sugerindo assim que de fato a via de p53 possa estar envolvida neste processo.
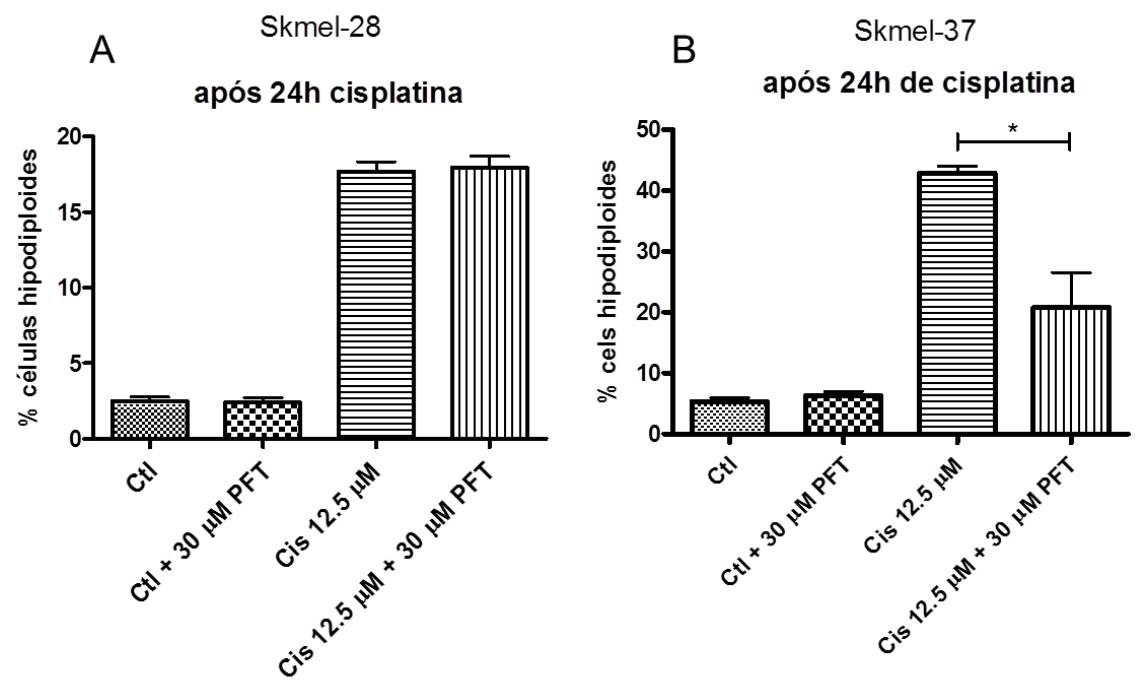

Figura 62. Morte celular em Skmel-28 (A) e Skmel-37 (B) após o uso de pifithrin- $\alpha$. Resultados mostram média e desvio padrão de ensaio em triplicata. Ensaio representativo de triplicatas independentes. * p < 0.05 . 


\subsubsection{Caracterização das vias de morte por exposição à cisplatina}

Uma vez sugerido que a via de p53 poderia estar relacionada com a resistência ao tratamento com cisplatina, procurou-se explorar melhor os mecanismos que contribuiam para o desencadeamento de morte após cisplatina em melanomas.

A primeira questão a ser analisada foi se a fase do ciclo celular contribuia para a morte celular causada por cisplatina. Neste caso em específico, porque cisplatina causa lesões genômicas, dentre outras, que acabam por interferir com processos de duplicação e transcrição. Para verificar se a passagem pela fase $\mathrm{S}$ do ciclo celular poderia interferir com a resposta, procurou-se estimular/inibir o ciclo celular através da quantidade de soro fetal. Desta maneira as células foram tratadas com $2 \%$ de soro para inibir o ciclo celular e outro grupo com $20 \%$ para estimular o ciclo. Em ambas as situações descritas, as células foram tratadas com cisplatina. A figura 63 demonstra os resultados do experimento. Inicialmente verificou-se realmente se o tratamento com diferentes concentrações de soro tem efeito no ciclo celular. Como mostrado na figura 63A, é possível verificar que a concentração de $20 \%$ de soro aumenta em cerca de $10 \%$ a quantidade de células em ciclagem (S/G2/M), o que também pode ser observado nos histogramas representativos mostrados (Figura 63B). Quando se observa o efeito da diferença de concentração na resposta ao quimioterápico, se observa que para ambas as linhagens a inibição do ciclo celular leva a uma menor taxa de morte (Figura 63C). 
a

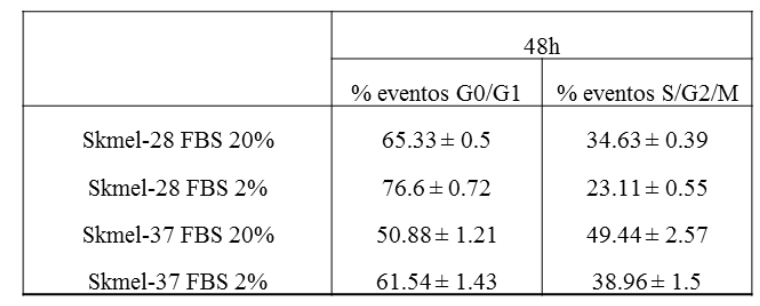

b

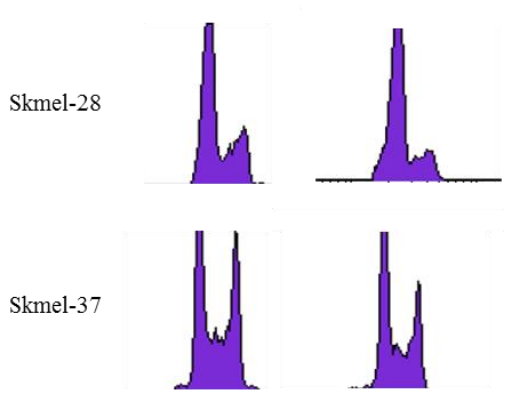

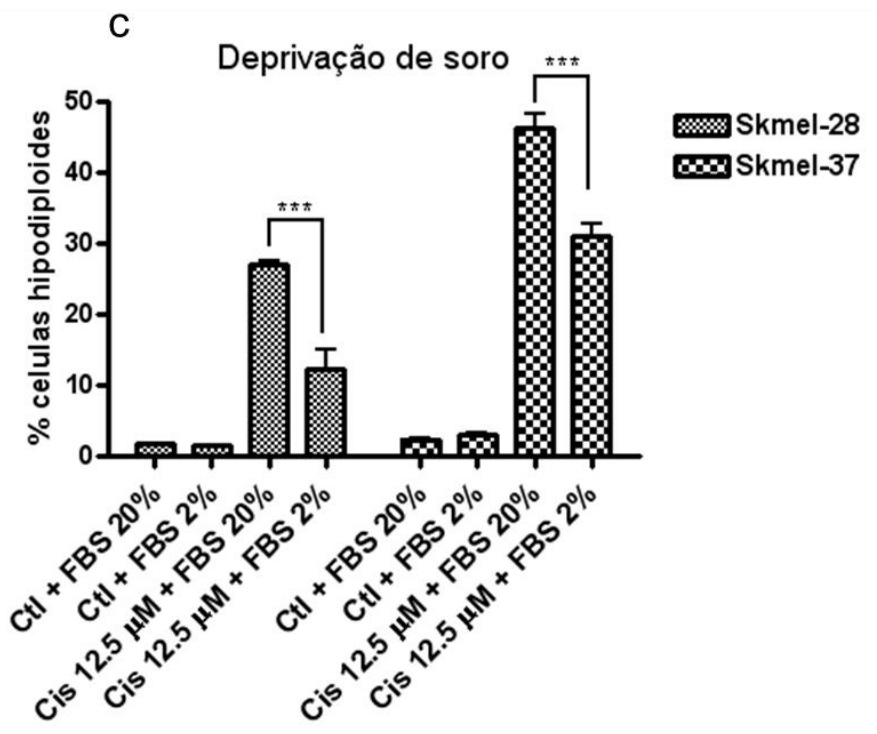

Figura 63. Análise do efeito do ciclo celular na resposta à cisplatina. (A) Média e desvio padrão da porcentagem de eventos em cada uma das fases do ciclo celular nas condições de concentração de soro. (B) Imagem representativa dos histogramas referentes às concentrações do soro. (C) Gráfico com a porcentagem de células hipodiplóides referente à sensibilidade à cisplatina em relação à concentração de soro. Resultados mostram média e desvio padrão de ensaio em triplicata. Ensaio representativo de triplicatas independentes. $* * * \mathrm{p}<0.001$.

Os resultados sugerem que a passagem pela fase $\mathrm{S}$ do ciclo celular pode ser mais letal no uso de cisplatina. Isto porque, provavelmente o acúmulo de lesões genômicas causadas por cisplatina, durante a fase de replicação de DNA cause maiores consequências e desencadeie processos de morte.

Seguindo a intenção de caracterizar o processo de morte relacionado à cisplatina nestas duas linhagens, procuramos entender as possíveis vias moleculares envolvidas. $\mathrm{O}$ processo de desencadeamento de morte se mostra bem complexo, com a ativação de várias sub-vias as quais levam a ativação de mecanismos de morte, podendo este ser por 
morte do tipo apoptose onde há a ativação da via Caspase. Analisou-se a expressão de duas proteínas importantes para a regulação do mecanismo de morte celular, BCL-2 e PUMA $\alpha / \beta$. Enquanto BCL-2 atua como proteína anti-apoptótica, PUMA $\alpha / \beta$ age como proteína pró-apoptótica. O resultado da expressão destas das proteínas pode ser vista na Figura 64.

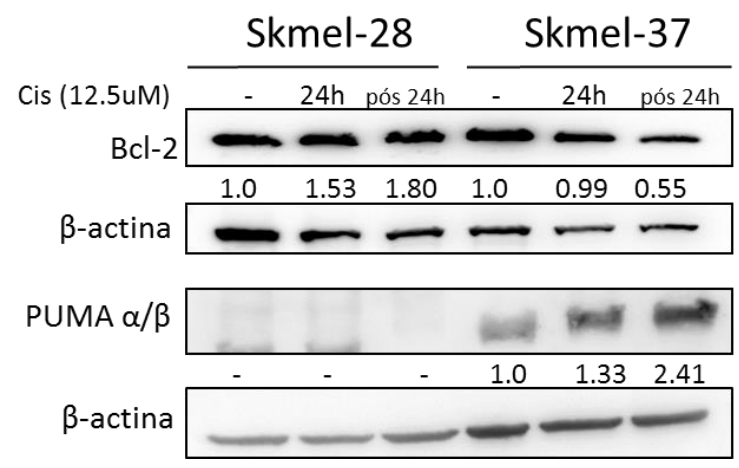

Figura 64. Western Blotting para BCL-2 e PUMA $\alpha / \beta$.

Os resultados corroboram com os achados para sensibilidade à cisplatina, isto porque na linhagem Skmel-28, mais resistente, a expressão de BCL-2 aumentou conforme a exposição enquanto em Skmel-37 diminuiu. Já com relação a expressão de PUMA $\alpha / \beta$, nota-se que sua expressão aumenta conforme o tratamento com cisplatina em Skmel-37, porém em Skmel-28 é possível observar a não expressão da proteína, mesmo após o tratamento com cisplatina. Este resultado reflete uma importante característica que tem justamente se desenhado, a participação de p53 na resposta à cisplatina. Isto porque PUMA $\alpha / \beta$ é um alvo downstream de $\mathrm{p} 53$, o que reforça tal participação desta via.

Os resultados mostram que o tratamento com cisplatina leva a um desbalanço dos fatores pró e anti-apoptóticos, no caso PUMA $\alpha / \beta$ e BCL-2. O desbalanço destes 
fatores é primordial para a ativação ou não das vias efetoras de apoptose, como a ativação das Caspases 3 e 7. Sendo assim, nós verificamos a ativação de Caspase 3 e 7 nas linhagens após o tratamento com cisplatina, como uma análise complementar dos processos de morte envolvidos. Neste experimento, as linhagens foram tratadas com cisplatina, conforme metodologia já utilizada e a marcação da atividade Caspase 3/7 foi medida através de peptídeo fluorescente ativado por atividade das Caspases citadas e que atuam como efetoras, cuja fluorescência pode ser adquirida por citometria. Desta maneira, a verificação da atividade Caspase 3/7 se deu pela análise da intensidade média de fluorescência emitida. A figura 65 demonstra os resultados para a análise da ativação de Caspase 3/7 das linhagens.

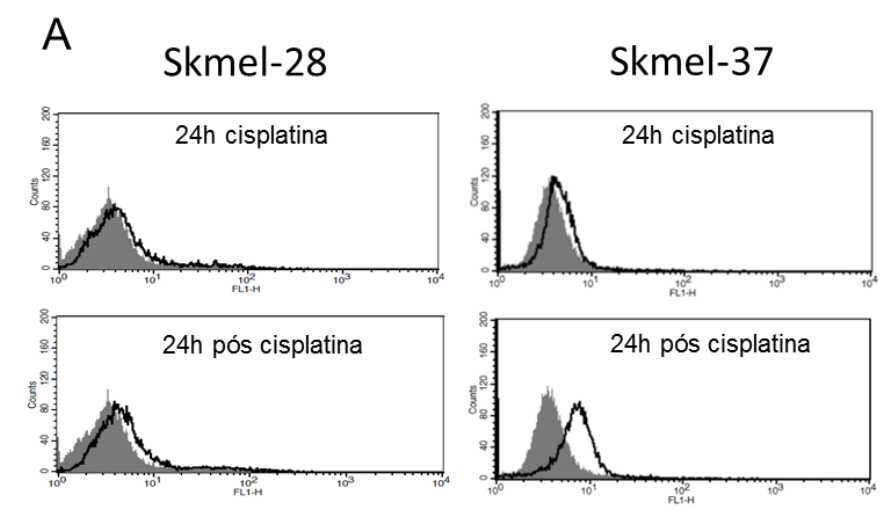

B
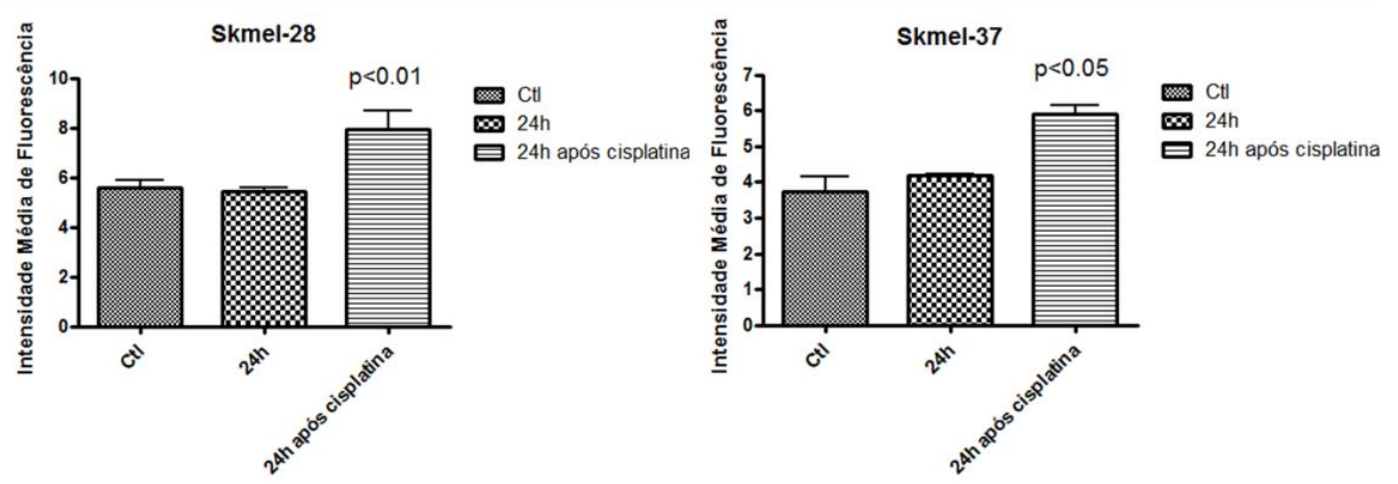

Figura 65. Análise da ativação de Caspase 3/7. (A) Análise de histogramas quanto aos picos de fluorescência. (B) Gráfico com a análise da intensidade média de fluorescência do ensaio de ativação de Caspase 3/7 nas linhagens de melanoma utilizadas. Resultados mostram média e desvio padrão de ensaio em duplicata. Ensaio representativo de triplicatas independentes. 
Os resultados demonstraram que houve maior ativação de Caspase 3/7 em Skmel-37 quando se analisa o deslocamento dos histogramas em comparação ao controle (Figura 65A) e também quando se compara ao deslocamento apresentado por Skmel-28. No entanto, quando os dados de intensidade média de fluorescência são postos em gráficos (Figura 65B), é possível verificar que a ativação de Caspase 3/7 é significativa para ambas as linhagens no tempo de $24 \mathrm{~h}$ após tratamento com cisplatina por 24h. Uma análise mais detalhada do ensaio de Caspase 3/7, mostrando a aquisição dos eventos pela fluorescência pode ser visto em Anexo E.

\subsubsection{Modulação da atividade de p53 e sua relação com resposta à cisplatina}

Os resultados demonstrados até agora sugerem fortemente a o papel de p53 na resposta a cisplatina em melanomas. Para confirmar este papel, além dos resultados com o uso de pifithrin- $\alpha$, optou-se por restaurar a atividade p53 na linhagem Skmel-28. Para tal, usamos de transdução viral para re-expressão de p53, onde tal expressão estaria sob controle transcricional de promotor responsivo a p53 (Strauss \& Constazi-Strauss, 2004).

Após a transdução e a seleção de células transduzidas, as mesmas células Skmel28 expressando p53 e as células controle expressando GFP foram tratadas usando a mesma metodologia descrita e testada para a expressão de proteínas que já foram analisados anteriormente. Os resultados podem ser visto na figura 66. 

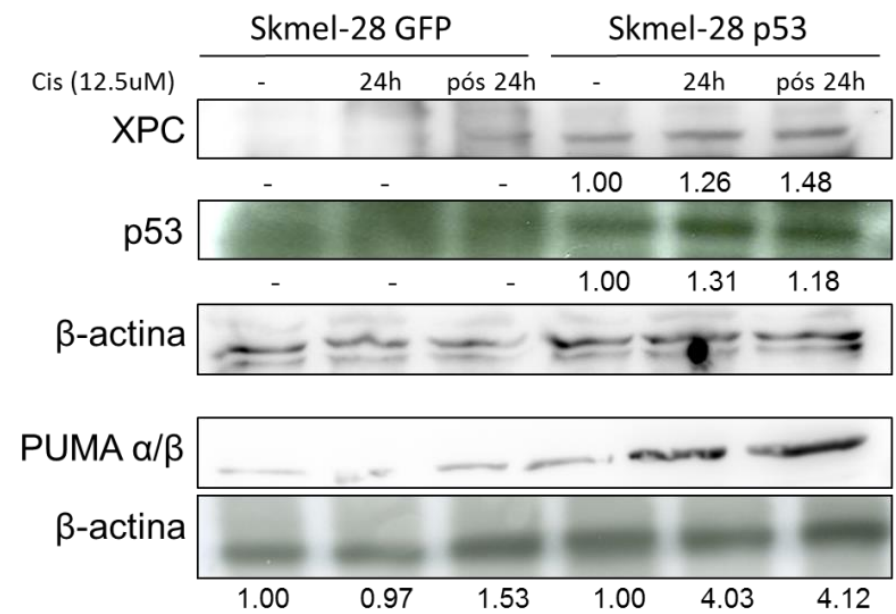

Figura 66. Western Blottings da expressão de XPC, p53 e PUMA $\alpha / \beta$ na linhagem Skmel-28 transduzida com p53 e GFP.

Os resultados em geral demonstram que a re-expressão de p53 em Skmel-28 aumentou a expressão de proteínas downstream de p53 como XPC e PUMA $\alpha / \beta$, confirmando os dados anteriores que mostravam alta expressão destas proteínas em Skmel-37, linhagem que apresentava p53 funcional.

Uma vez que a re-expressão de p53 levou a um aumento da expressão de PUMA $\alpha / \beta$, resolveu-se verificar se ao restaurar a via de p53 em Skmel-28, a mesma pode se tornar mais sensível à exposição à cisplatina. A figura 67 demonstra o resultado da análise de morte celular na linhagem Skmel-28 transduzida com p53 e controle GFP. O resultado demonstra claramente que a re-expressão de p53 aumentou a sensibilidade da linhagem Skmel-28, reforçando o papel desta via na sensibilidade/resistência ao quimioterápico. 


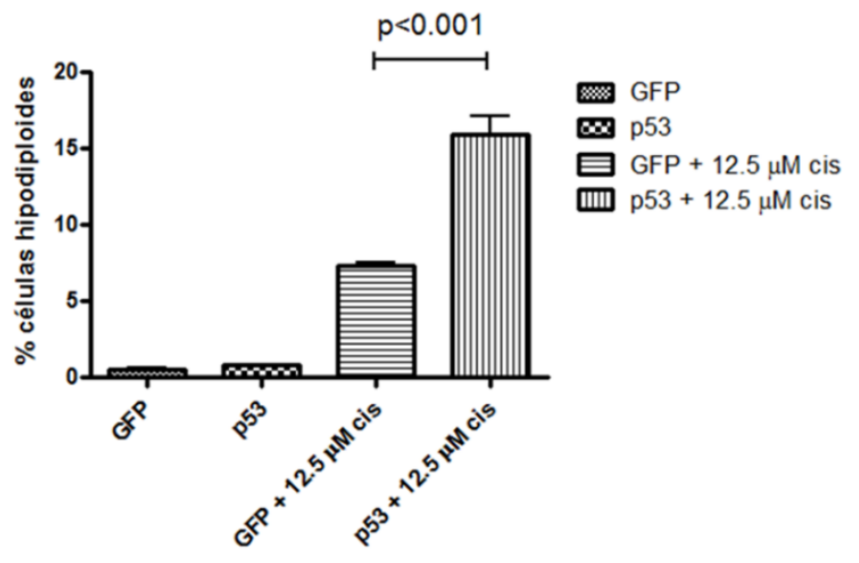

Figura 67. Morte celular em Skmel-28 transduzidas para expressar p53 e GFP. Resultados mostram média e desvio padrão de ensaio em triplicata. Ensaio representativo de triplicatas independentes.

Como os dados de restauração da atividade de p53 através da transdução em Skmel-28 demonstraram que este recurso aumenta a sensibilidade à cisplatina, procuramos também testar a possibilidade de aumentar a resposta ao quimioterápico através do uso farmacológico de inibidores de HDM-2, repressor natural de p53. Para tal, utilizamos de Nutlin-3, composto descrito por inibir a atividade de HDM-2 em conduzir p53 à degradação, liberando assim a atividade desta última. De fato, inibidores da atividade HDM-2 já foram testados como possíveis compostos à terapia de melanomas (Verhaegen et al., 2012). Duas concentrações de Nutlin-3 foram usadas e as duas linhagens Skmel-28 e Skmel-37 foram testadas para morte celular, seguindo a metodologia já usada anteriormente (Figura 68). Os resultados mostraram que o uso de concentração mais baixa de Nutlin-3 $(1 \mu \mathrm{M})$ aumentou significativamente a taxa de morte celular em ambas as linhagens, enquanto que em concentração maior $(5 \mu \mathrm{M})$, embora ainda tenha aumentado a taxa de morte em relação ao controle em Skmel-28, essa taxa foi menor que a concentração menos. Ao contrário, em Skmel-37, a maior concentração de Nutlin-3 inibiu a morte por cisplatina no tempo analisado. 

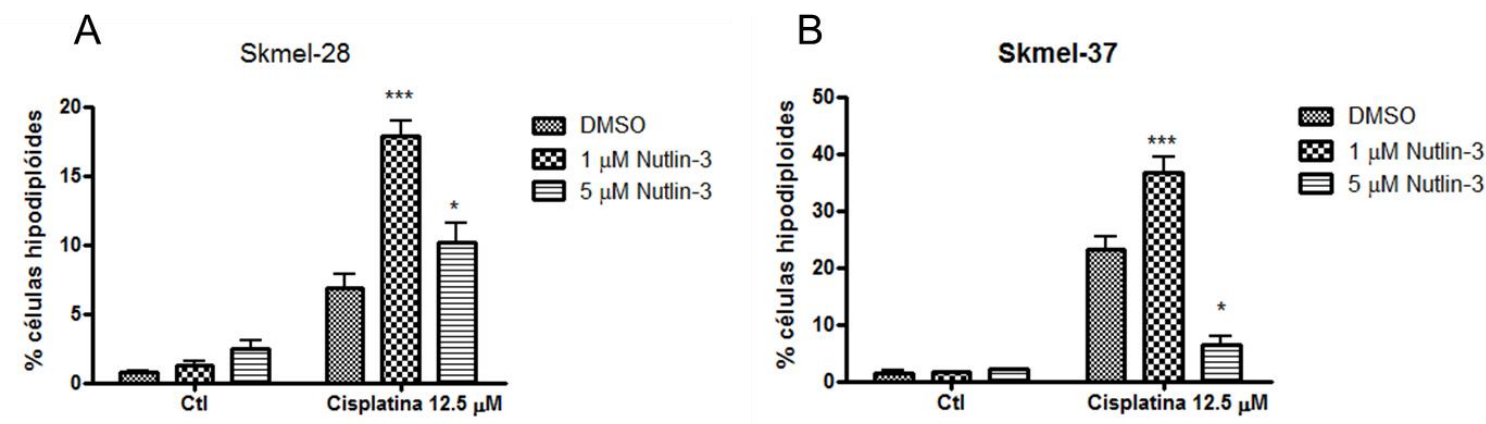

Figura 68. Morte celular em Skmel-28 (A) e Skmel-37 (B) após cisplatina e Nutlin-3. Resultados mostram média e desvio padrão de ensaio em triplicata. Ensaio representativo de triplicatas independentes. As analises estatísticas se referem à comparação com o controle. * $\mathrm{p}<0.05$; *** $\mathrm{p}<$ 0.001 .

Para verificar se esse efeito de Nutlin-3 afeta a sobrevivência das células em longo prazo, ensaio de sobrevivênvia por formação de colônias também foi realizado. A figura 69 demonstra os resultados.
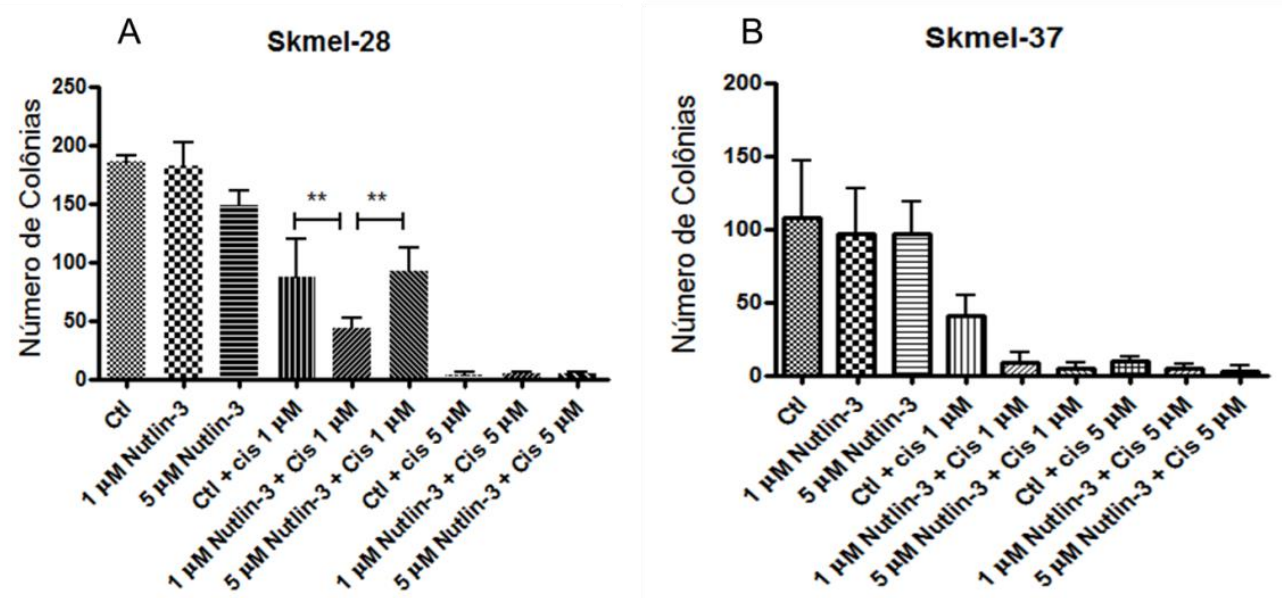

Figura 69. Ensaio de sobrevivência por formação de colônias em Skmel-28 (A) e Skmel-37 (B). Resultados mostram média e desvio padrão de ensaio em triplicata. Ensaio representativo de duplicatas independentes. As analises estatísticas se referem à comparação com o controle. ** $\mathrm{p}<0.01$.

A partir dos resultados, pode-se observar que em ambas as linhagens, o uso de Nutlin-3 aumentou a sensibilidade ao quimioterápico (para $1 \mu \mathrm{M}$ de cisplatina), sendo neste caso o número de colônias menor quando comparado ao tratamento apenas com 
cisplatina, embora apenas em Skmel-28 o resultado tenha sido significativo. Estes resultados corroboraram com os resultados apresentados para morte celular na mesma concentração de Nutlin-3. No entanto, o uso de concentração maior de Nutlin-3 (5 $\mu \mathrm{M})$, demonstrou resultados diferentes, sendo protetivo para Skmel-28 e para Skmel-37 em comparação ao tratamento com dose menor. No entanto, para Skmel-37 demostrou ser mais protetivo até em relação ao controle apenas com cisplatina. Diante destes resultados diferentes, é possível assumir que uma concentração mais alta de Nutlin-3 pode alterar outras vias, além da via alvo HDM2-p53, contribuindo assim para tais resultados controversos.

Para finalizar os resultados referentes ao papel de p53 na resposta à cisplatina, resposta esta que pode estar relacionada à expressão de PUMA $\alpha / \beta$, importante fator pró-apoptótico, a análise foi estendida a outras linhagens de melanoma com diferentes funcionalidades de p53. Para tal utilizamos a linhagem Mewo (frequentemente descrita como p53 mutada) e a linhagem SBCL-2 (possuindo p53 funcional) e verificamos em ambas a expressão de p53 e PUMA $\alpha / \beta$, além de verificar a sensibilidade das linhagens à cisplatina e à Nutlin-3. Os resultados apresentados na figura 70 , mostram que a expressão de PUMA $\alpha / \beta$ só é observada em SBCL-2, no mesmo modo que p53 aumenta de expressão conforme a exposição à cisplatina, diferentemente dos padrões visto em Mewo. Além disso, novamente o uso de menor concentração de Nutlin-3 aumentou significativamente a sensibilidade à cisplatina nas duas linhagens (Figura 70C e D), embora novamente em altas concentrações Nutlin-3 apresenta resultados diferentes conforme a linhagem usada. 

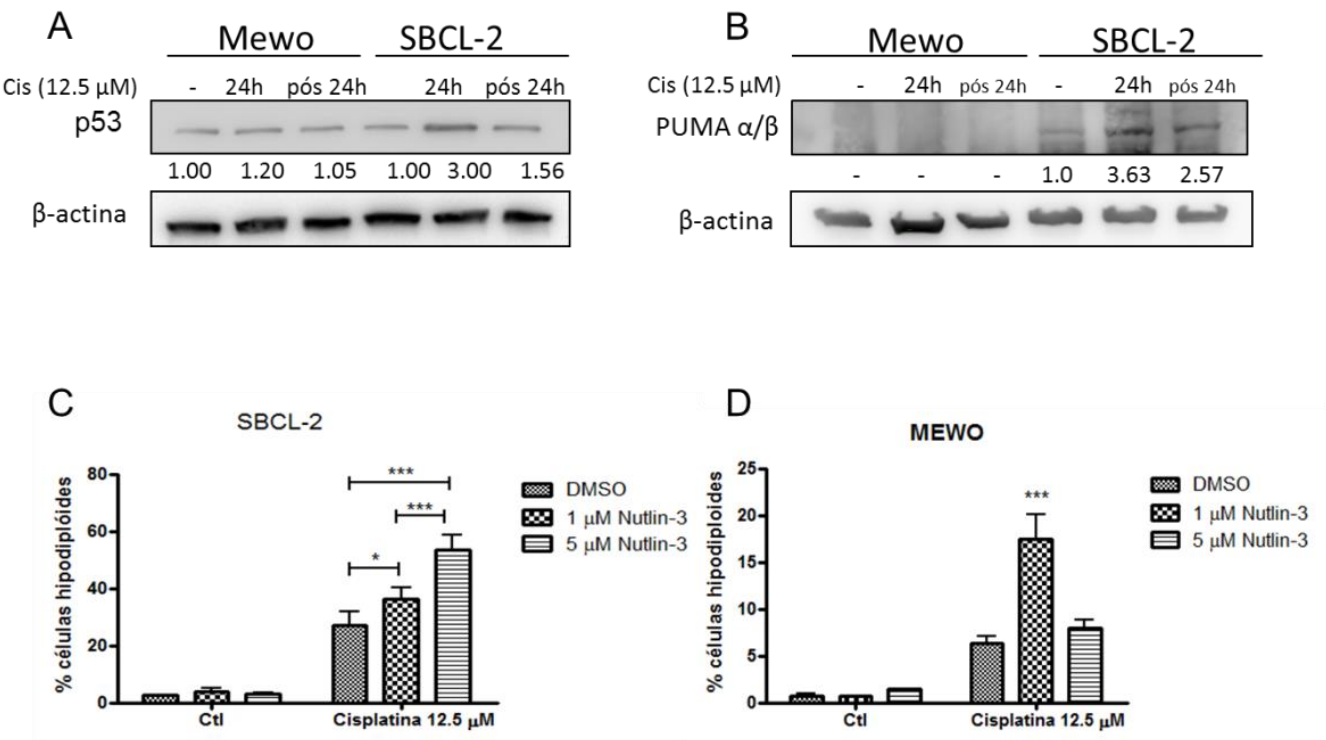

Figura 70. Western Blotting para p53 (A) e PUMA $\alpha / \beta$ (B). Morte celular em SBCL-2 (C) e Mewo (D) após cisplatina e Nutlin-3. Resultados mostram média e desvio padrão de ensaio em triplicata. Ensaio representativo de duplicatas independentes. As analises estatísticas se referem à comparação com o controle. $* \mathrm{p}<0.05 ; * * * \mathrm{p}<0.001$.

\subsubsection{Papel de XPC na resistência à cisplatina}

Os resultados vistos para a expressão de XPC após cisplatina demonstram claramente que o gene apresenta expressão condicionada a atividade de p53. Com este fato, é possível sugerir que XPC e consequentemente, a via GGR-NER possa exercer algum papel referente à resistência ao quimioterápico. A literatura apresenta resultados controversos quanto a participação de XPC e GGR-NER na atividade de reparo a danos causados por cisplatina (Bowden et al., 2010; Enoiu et al., 2012; Barckhausen et al., 2014).

Para compreender se a expressão de XPC estaria relacionada à resistência à cisplatina em melanomas, utilizamos da técnica de siRNA para silenciamento gênico de XPC e posterior análise da resposta de Skmel-37 frente ao quimioterápico. A uso de siRNA para silenciamento de XPC já foi utilizado e mostrado anteriormente na figura 36. Para este caso em específico, utilizou-se da mesma metodologia descrita 
anteriormente para silenciamento e também para a exposição à cisplatina. $\mathrm{O}$ resultado da sensibilidade ao quimioterápico verificado pela taxa de morte celular pode ser visto na figura 71 .

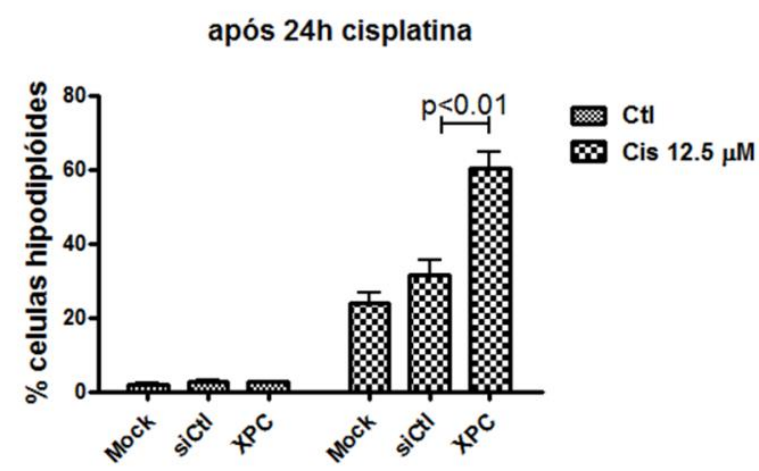

Figura 71. Morte celular após cisplatina utilizando-se siRNA para XPC. Resultados mostram média e desvio padrão de ensaio em triplicata. Ensaio representativo de duplicatas independentes.

Os resultados demonstraram claramente que a inibição de XPC levou a um considerável aumento na sensibilidade das células Skmel-37 à cisplatina. Estes resultados já tinham sido mostrados na figura 42, onde o silenciamento de XPC ou de hHR23B foram testados para diferentes quimioterápicos. Os resultados então sugerem que XPC tenha algum papel na resistência à cisplatina, no entanto, a expressão de XPC não pode ser considerável um fator preponderante para tal resistência, uma vez que mesmo contribuindo na resistência, sua pouca expressão em Skmel-28, a mesma apresenta maior resistência quando comparada a Skmel-37.

\subsubsection{Sensibilidade à cisplatina em componente heterogêneo para expressão de p53}

A pesquisa em Oncologia tem recentemente pontuado a importância da heterogeneidade tumoral na biologia dos tumores. Para simularmos certa heterogeneidade quanto à funcionalidade de p53 e verificar como as populações de 
células se comportam em ambiente heterogêneo, preparamos um ensaio onde as duas populações de células, Skmel-28 expressando p53 e Skmel-28 expressando GFP, seriam plaqueadas em proporção de $50 \%$ cada e as mesmas seriam tratadas com cisplatina por 24h a $12.5 \mu \mathrm{M}$ (conforme protocolo já utilizado), sendo acompanhado posteriormente a proporção de cada linhagem após os tempos de 24, 48 e 72 h após o tratamento com cisplatina. Esta análise de proporcionalidade pode ser feito através de aquisição via FACS, uma vez que a linhagem expressando GFP apresentaria maior deslocamento no espectro do verde em comparação a linhagem expressando p53. A figura 72 ilustra os resultados obtidos desta análise. Primeiramente é possível verificar (Figura 72A) que as duas linhagens apresentam evidente diferença quanto à fluorescência, possibilitando assim a separação das linhagens. Quando se analisa os histogramas referentes ao período de tratamento (B para 24h, C para 48h e D para 72h após exposição à cisplatina por 24h), é possível verificar que os controles mantém a proporcionalidade de aproximadamente $50 \%$ de cada população, no entanto a proporcionalidade das linhagens muda consideravelmente após a exposição à cisplatina, conforme a passagem do tempo. Neste caso, após a passagem do tempo é possível verificar maior concentração de células GFP em comparação às células expressando p53. 


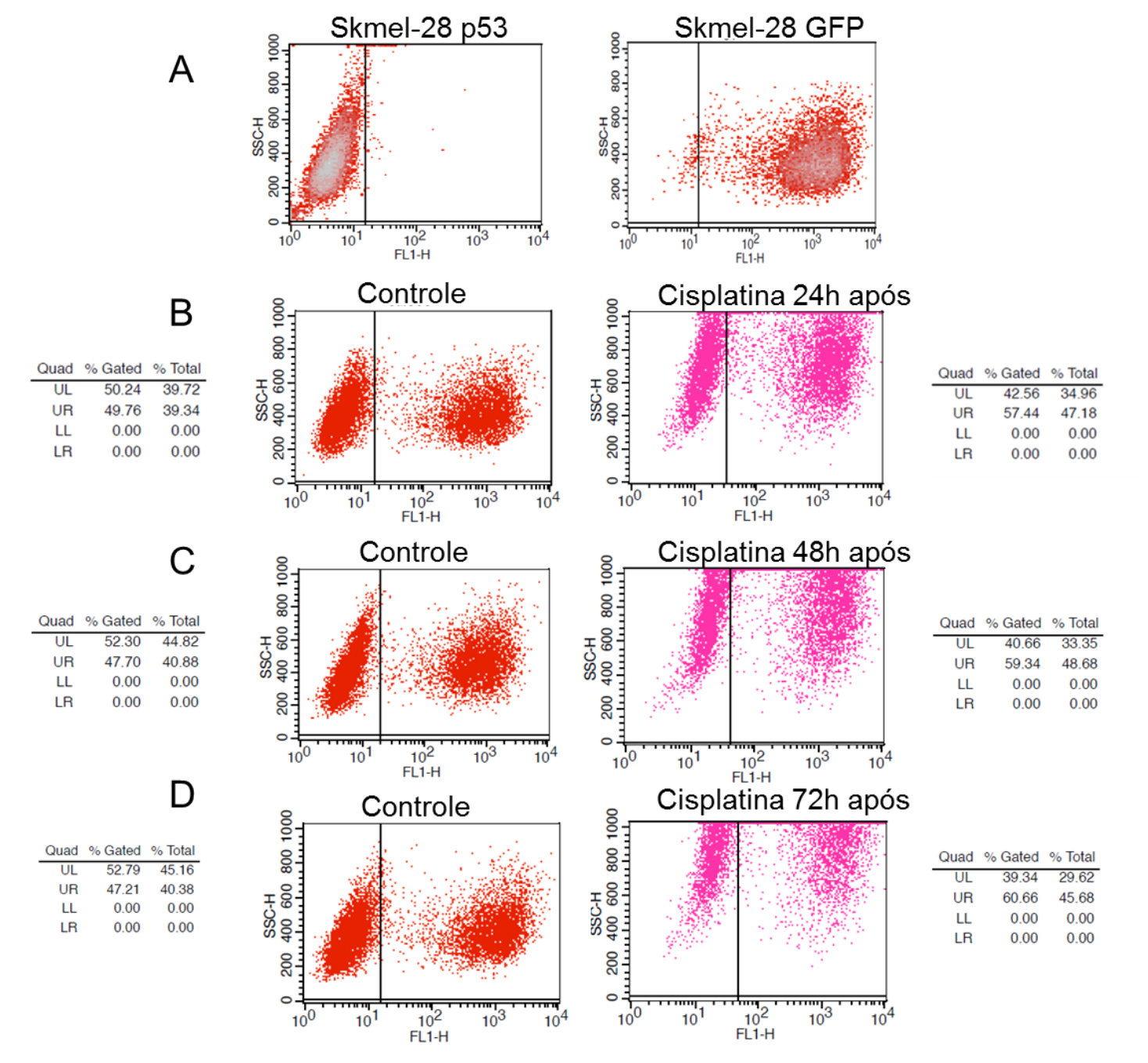

Figura 72. Histogramas obtidos para o ensaio com componente heterogêneo de populações expressando p53 ou GFP. (A) Histogramas para linhagens p53 e GFP separadas. (B) Histogramas para 24h após cisplatina. (C) Histogramas para $48 \mathrm{~h}$ após cisplatina. (D) Histogramas para $72 \mathrm{~h}$ após cisplatina.

Os resultados na proporcionalidade das subpopulações após os tempos analisados estão melhor representados na Figura 73. É possível notar que já a partir do tempo de 24 h após, a proporção das células já é desigual e significativamente diferente. Esta diferença se mantém conforme a passagem do tempo após a exposição à cisplatina. 


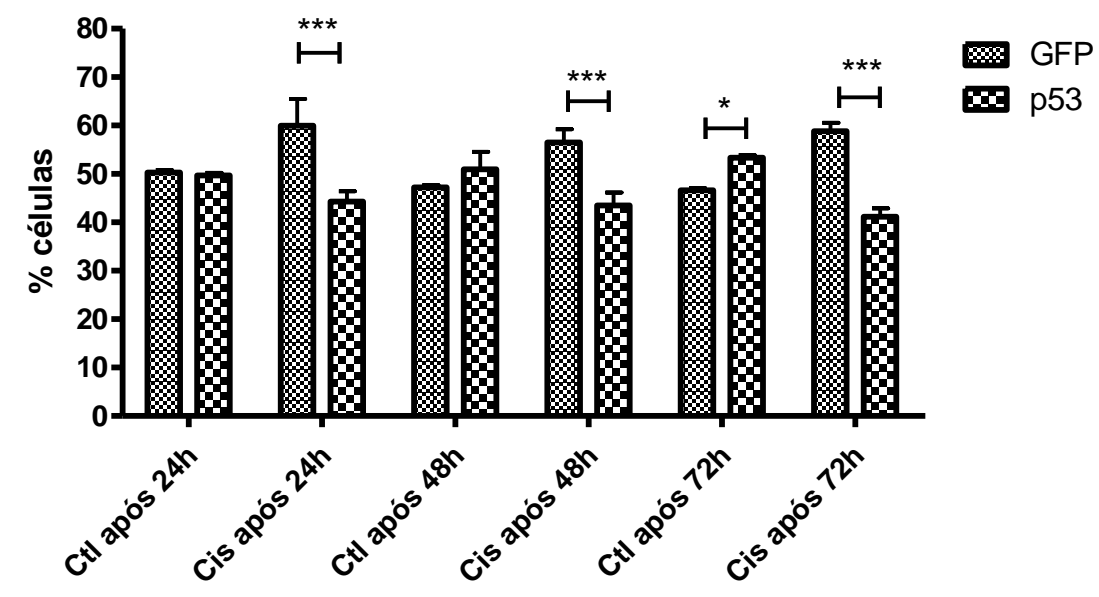

Figura 73. Gráfico mostrando a proporcionalidade das subpopulações de Skmel-28 transduzidas com GFP e p53 após exposição à cisplatina conforme os tempos determinados. População exposta à $24 \mathrm{~h}$ de cisplatina à $12.5 \mu \mathrm{M}$ (Cis). Resultados mostram média e desvio padrão de ensaio em triplicata. Ensaio representativo de triplicatas independentes. $* \mathrm{p}<0.05 ; * * * \mathrm{p}<0.001$.

Os resultados corroboram com os resultados já mostrados quanto ao papel de p53 na sensibilidade à cisplatina, tanto quanto às linhagens quanto aos resultados obtidos na transdução de p53 em Skmel-28. 


\section{DISCUSSÃO}

5.1 P53, XPC, Reparo de DNA e Melanoma: Como 553 pode influenciar a atividade de reparo de DNA e sensibilidade à UVB e cisplatina

Melanomas se originam a partir da transformação maligna de melanócitos cutâneos, as células produtoras de pigmentos que residem na camada basal da epiderme na pele humana. A maioria dos melanoma parece surgir de novo, embora eles também possam surgir a partir de nevos comuns pré-existentes, ou nevos displásicos (Klekotka et al., 2007; Weatherhead et al., 2007). Melanomas podem surgir em áreas de exposição solar crônicas e nãocrônicas, onde ambos apresentam padrões diferentes de mutações (Curtin et al., 2005), suportando a existência de distintas vias moleculares que podem ou não depender de exposição à UV.

O papel da exposição UV na carcinogênese de tumores cutâneos é bem descrito para os carcinomas basocelular e espino celular, sendo para melanoma esta relação controversa. No entanto, com o avanço das pesquisas em melanoma, principalmente com os resultados de sequenciamento de ultima geração (Pleasance et al., 2010), ficouse evidente a participação da radiação UV no acúmulo de mutações potencialmente carcinogênicas. Dentro do espectro da radiação UV, UVB está bem documentada como sendo a principal causa do câncer de pele, principalmente o câncer não-melanoma.

Estudos com camundongos transgênicos tem demonstrado o papel de UVB na patogênese do melanoma (Noonan et al., 2000; Noonan et al., 2001; Noonan et al., 2003). A principal ação de UVB está no seu potencial de causar lesões do tipo CPD e fotoprodutos 6-4 no DNA as quais podem levar a transições de $\mathrm{C} \rightarrow \mathrm{T}$ ou $\mathrm{CC} \rightarrow \mathrm{TT}$. Regiões de DNA contendo 5-metil-citosina, facilmente encontradas em regiões 
promotoras e não transcritas, foram identificadas como hotspots para mutações induzidas por UVB (Tommasi et al., 1997; Mitchell D, 2000; Lee \& Pfeifer, 2003). Justamente estas regiões promotoras e não transcritas que foram destacadas como regiões de maior ocorrência de mutações do tipo UV (Pleasance et al., 2010). Além de lesões diretas, alguns resultados também tem mostrado que UVB pode provocar a geração de estresse oxidativo (Horikawa-Miura et al., 2007; Jiang et al., 2007).

Em uma análise celular, a exposição à UVB, assim como demais lesões genotóxicas, leva a expressão de p53, a qual atua em diversas respostas celulares desde a expressão de proteínas responsáveis pela parada do ciclo celular, reparo de DNA e também proteínas relacionadas à morte celular. Quando focamos o papel de p53 diretamente no reparo de DNA, notamos que este é responsável pela expressão de importantes proteínas que agem no reconhecimento de lesões, principalmente para lesões UV, como DDB-2 e XPC (Stoyanova et al., 2009; Hastak et al., 2012). Neste caso, p53 tem papel importante na cinética de reparo de lesões por UV, uma vez que a expressão das proteínas responsáveis pelo reconhecimento das lesões fica a seu cargo, justificando assim o papel de p53 como modulador de XPC, mais especificamente alterando sua expressão. De fato, alterações na atividade transcricional de p53 em genes de reparo contribui para menor eficiência na remoção de lesões por UV (Batista et al., 2009).

Correlacionando o papel de p53 na via NER e o papel da exposição UV na carcinogênese cutânea, seria de se esperar que alterações em p53 fossem importantes passos na transformação, uma vez que deficiências na via culminariam em menor expressão de proteínas como DDB-2 e XPC e consequentemente levando ao possível acúmulo de mutações. Alto acúmulo de mutações em p53 (e também de mutações UV) 
são descritas em CBCs (Carcinoma Baso-celular) e CECs (Carcinoma Espino-celular) (Backvall et al., 2004). Contudo, a proporção de melanomas primários que apresentam mutações no gene TP53 é frequentemente baixa, por volta de 7\% das amostras, embora podendo variar de 0 a $24 \%$ dependendo do estudo realizado (de Snoo \& Hayward, 2005). Neste contexto, o de baixa taxa mutacional em TP53 em melanomas, que a utilização de linhagens com diferentes status de funcionalidade de p53, como Skmel-28 e Skmel-37, pode ser útil para entender melhor o papel desta proteína na biologia de melanomas, principalmente quanto a respostas à UVB e cisplatina.

A primeira questão que esta tese teve como objetivo foi o de explorar o papel funcional que p53 exerceria, mediante XPC e na sua função de reparo de DNA, na resposta a UVB, justamente procurando entender essa intrigante questão relacionada à baixa taxa mutacional que p53 apresenta. Inicialmente, a caracterização da expressão de proteínas como XPC, DDB-2 e p21 em linhagens com diferente status funcional de p53, de fato não apresenta grande novidade, visto que já é bem descrito. O quadro geral de resultados mostra que enquanto Skmel-28, que apresenta menor atividade de p53, demonstra menor expressão de genes de reparo de DNA, menor eficiência de reparo e consequentemente maior sensibilidade à UVB, Skmel-37 que apresentou maior eficiência de atividade p53 demonstrou efeitos contrários. Estes resultados trazem a tona e servem de discussão para o papel de p53 na gênese de melanomas.

O ponto inicial da discussão se baseia no fato de que p53 apresenta baixa taxa de mutações em melanomas, principalmente em amostras de melanomas primários, já que em amostras metastáticas, essa taxa pode ser um pouco maior (de Snoo \& Hayward, 2005). Estes números sugeriram aos pesquisadores em melanoma que mutações em p53 não estariam correlacionadas diretamente com os processos iniciais da transformação 
desta neoplasia. De fato, pacientes portadores de mutações germinativas em p53, pacientes acometidos pela síndrome de Li-Fraumeni, são raros em demonstrar desenvolvimento de melanomas, em comparação com outros tipos de tumores internos (Kollipara et al., 2014). Associando os dados apresentados junto com a observação de aparecimento raro de melanomas em pacientes Li-Fraumeni e a baixa taxa de mutações em TP53 em amostras de melanomas, especula-se aqui que mutações em TP53 se torne uma desvantagem para o desenvolvimento desta neoplasia em seus passos iniciais. Isto porque, mutações iniciais levariam a menor taxa de reparo de DNA e como consequência aumentando sua sensibilidade à exposição UV, contribuindo então para a eliminação de possíveis clones alterados geneticamente.

Tal especulação iria de encontro aos dados de mutação em TP53 que atuam no desenvolvimento dos outros tipos de tumores cutâneos. Nestes casos, mutações em TP53 podem ser observadas em lesões pré-cancerosas como, por exemplo, queratoses actínicas onde a taxa de mutação em amostras pode ser de até $66 \%$ (Ziegler et al., 1994). Se mutações em TP53 podem ser importantes no desenvolvimento de CBCs e CECs e não no desenvolvimento de melanomas, o que diferiria entre ambas as neoplasias visto que o principalmente agente etiológico é a exposição à UV? Esta diferença pode estar no fato da existência de padrões diferentes de exposição solar no que diz respeito à etiologia dos tumores cutâneos. Enquanto $\mathrm{CBCs}$ e $\mathrm{CECs}$ são tidos como resultantes de padrões de exposição crônica solar, melanomas são atribuídos a padrões intermitentes de exposição. Esta diferença de padrão de exposição que poderia residir o papel de p53 na carcinogênese cutânea. Em exposições intermitentes e de alta intensidade, como para melanomas, a quantidade de lesões UV causadas poderia ser demasiada para células com p53 mutadas e a consequente menor habilidade em reparo 
de DNA levaria estas células a morte. Já na exposição crônica, os danos causados ao longo da história de exposição de vida do indivíduo permitiria a acumulação de mutações carcinogênicas.

Embora possamos sugerir que alterações severas em p53 como mutações deletérias não sejam vantajosas nos passos iniciais da carcinogênese de melanomas, não se pode excluir a importância da atenuação da via para a progressão da doença. De fato, estudos mostram que em melanomas, embora não apresente mutações, p53 apresenta baixa funcionalidade, esta representada pela baixa expressão de genes downstream de p53 (Houben et al., 2011). Estudos subsequentes sugeriram que a progressão de nevus para melanomas pode estar relacionada a mecanismos que justamente inibam a atividade de p53. Existem diversos fatores que podem estar relacionados com a inatividade de p53 em melanomas, com por exemplo expressão de repressores como HDM-2, ausência de expressão de p14 e demais proteínas que interajam com p53 (revisto em Francisco et al., 2013). O pressuposto de que melanócitos ainda mantém a atividade p53 ao contrário de melanomas, reforça a ideia de que mutações em p53 não são vantajosas para o processo carcinogênico como discutido anteriormente.

Outro dado importante que veio a adicionar e ajudar a elucidar o papel de p53 não estar mutado em melanomas veio do estudo de Verhaegen e colaboradores (Verhaegen et al., 2012). Em primeiro lugar, o estudo indicou que depleção de p53 em melanócitos levou a um aumento nos defeitos mitóticos das células, fato este não observado nas células de melanoma, mostrando que os danos nos processo mitóticos já eram bem menores. Além disso, o estado basal de funcionalidade que p53 apresenta em melanomas, mesmo com a menor atividade transcricional descrita, demonstrou ser essencial para o crescimento do melanoma, como: (i) atividade basal de p53 leva à 
expressão HDM-2, que por sua vez mantém os níveis basais de p53; (ii) este nível de p53 evita a ativação de um programa pró-senescência dependente de p53; (iii) em um estado basal, p53 não induz a expressão de p21, o que por sua vez não inibe E2F1. A expressão e funcionalidade de E2F1 contribui para a proliferação de células de melanoma; (iv) expressão de HDM-2 induz a activação de E2F1 de uma forma p53independente, contribuindo para a proliferação de células de melanoma. Em resumo, este estudo elucida novas funções do eixo p53-HDM-2 em melanomas. Além disso, o eixo p53-HDM-2 em melanomas é agora sugerido como um alvo promissor para o tratamento do melanoma, uma vez que a utilização do antagonista específico HDM-2 resgata a atividade de p53, levando a supressão do crescimento de melanoma e morte de células de melanoma (Ji et al., 2012).

Uma vez demonstrado o papel de p53 na sensibilidade à UVB em melanomas, seguiu-se com os passos de uma melhor caracterização dos processos de morte desencadeados. Esta caracterização se mostrou interessante no passo de explorar as vias de morte ativadas após a irradiação, isto porque, p53 está envolvido diretamente com a expressão de diversas proteínas relacionadas com o desencadeamento destes processos. Os resultados mostram algumas características importantes. Primeiramente foi possível notar que proteínas que estão diretamente relacionadas a p53, no sentido a serem reguladas diretamente, apresentam padrões diferentes de expressão após UVB nas linhagens analisadas. Proteínas pró-apoptóticas como PUMA $\alpha / \beta$ e BAD apresentaram maior expressão após 24h de exposição à UVB em Skmel-37, no entanto esta expressão é diminuída após 48h. Já com Skmel-28, a expressão destas proteínas se deu principalmente após 48h. Este padrão de expressão mostra que em Skmel-37 esta expressão se relaciona com a expressão de p53, no entanto para Skmel-28, houve uma 
expressão tardia, que pode ter sido ativada por vias alternativas, diferentes de p53, as quais podem também estar relacionadas com a maior sensibilidade desta linhagem. Este padrão de expressão se relacionou de maneira mais linear em Skmel-28, onde a expressão destas proteínas pró-apoptóticas se correlacionou também com a diminuição de expressão de BCL-2 e com o padrão de morte e sobrevivência destas células após 48h de exposição e também no ensaio de sobrevivência por ensaio clonogênico, respectivamente.

De qualquer maneira, é crucial ter em mente que a análise apenas da expressão de PUMA $\alpha / \beta$, BAD e BCL-2 não representa todas as possíveis vias de morte que podem ser ativadas em processos celulares. Processos autofágicos disparados por danos no DNA, incluindo danos causados pela exposição à UVB, também tem sido relacionados à morte celular e podem se encaixar como "outros processos de morte", além dos processos ditos clássicos, como apoptose dependente de caspase e necrose (Guimarães \& Linden, 2004). Não só danos diretos no DNA podem contribuir com a ativação de autofagia, mas também produção de espécies reativas também são descritas como fatores desencadeadores (Rodriguez-Rocha et al., 2011). Neste ultimo caso, a produção de ROS observada nas linhagens de melanoma também poderiam desencadear autofagia. Nos passos relativos a iniciação e prosseguimento do processo autofágico, algumas proteínas chave tem papel essencial e servem como marcadores da ativação do processo, sendo costumeiramente usados. As proteínas Beclin-1 (agindo na fase de nucleação de vesícula autofágica) e LC-3 (atuando na elongação da vesícula e manutenção do autofagossomo) são críticas para averiguação do processo e foram utilizadas também neste trabalho para análise da possível ativação de autofagia em melanomas (Maiuri et al., 2007). Mesmo sendo o processo autofágico fortemente 
influenciado por p53 (Zong \& Moll, 2008), os resultados analisados não evidenciaram qualquer participação de autofagia em melanomas após UVB, nos tempos analisados (24 e 48h), o que não exclui uma possível alteração e ativação das vias autofágicas em tempos menores ou até maiores. Os resultados então mostram que embora o processo de morte celular seja deflagrado por vias diferentes entre linhagens com diferença na funcionalidade de p53, este processo sugere ser independente de autofagia mas dependente de Caspase, visto que em ambas as linhagens houve ativação das Caspase efetoras de apoptose, no caso Caspase 3 e 7. Embora as duas linhagens apresentaram aumento significativo da fluorescência indicativa da ativação de Caspases 3/7, esse aumento foi maior em Skmel-28, o que justifica sua maior sensibilidade à UVB.

Além do já bem descrito papel das lesões CPD e 6-4 PP nos processos de morte (Batista et al., 2009), a exposição à radiação UV também pode levar a produção de espécies reativas de oxigênio, que por sua vez também pode contribuir com danos no DNA culminando com morte celular. Quando se fala da relação entre UV e espécies reativas, radiação do tipo UV-A é a melhor descrita para a produção deste tipo de moléculas, onde estudos têm mostrado que a apoptose desencadeada por irradiação UVA tem a participação de oxigênios singlets, peróxidos de hidrogênio, ânions superóxidos e radicais hidroxilas (Wenck et al., 2001). Para UVB, espécies reativas também podem desempenhar um papel na apoptose. Estudos mostraram que em células HeLa, a exposição à UVB também levou a produção de espécies reativas, as quais estiveram relacionadas ao processo de apoptose, embora em menor grau em relação às lesões diretas (Kulms et al., 2002). Uso de scavengers de espécies reativas nestes experimentos levou a inibição parcial do processo de morte celular, evidenciando o papel destas espécies no processo. 
Os resultados aqui apresentados, também mostraram a produção de espécies reativas após UVB. Esta produção foi maior nas linhagens Skmel-28 e também diminuidas quando a mesma linhagem foi transduzida com lentivirus para p53, demonstrando que a reativação da via de p53 pode levar a expressão de proteínas importantes para a neutralização de tais moléculas e também atuando na regulação do estado redox intracelular (Liu et al., 2008). Neste corpo de resultados, não se pode determinar quais proteínas foram mais importantes para a manutenção deste estado e como estavam relacionadas à atividade p53. De qualquer modo, procuramos entender se a produção de ROS estava tambem relacionada à morte celular.

Como o uso de DHR para detecção de espécies reativas não apresenta uma especificidade tão confiável a ponto de determinarmos precisamente o tipo de espécie reativa mais produzida, embora mais continuamente relatada a detecção de peróxidos (Henderson \& Chappell, 1993), para testar a relação entre estas espécies e morte celular nós utilizamos dois diferentes compostos que atuariam na neutralização destas moléculas. Catalase (proteina que atua na dismutação de peróxido de hidrogênio) e Tempol (composto mimético de superóxido dismutase) foram usadas com o intuito de neutralizar peróxidos de hidrogênio e ânios superóxidos respectivamente, e verificar se alterariam a sensibilidade à UVB. Os resultados indicaram, no entanto que o uso destes inibidores aumentou a sensibilidade à UVB. A supressão das espécies reativas com quantidades mais altas de Catalase ou Tempol aumentou a sensibilidade de ambas as linhagens à UVB. Estes resultados, embora antagônicos à hipótese inicial, propriciam discussões a respeito do papel de ROS pós UVB em melanomas.

Primeiramente os resultados podem até mesmo significar certo estado de “estresse" celular causado pelas concentrações maiores dos antioxidantes usados. Neste 
caso em específico, os resultados podem revelar mais um estado de overdose de antioxidantes do que um real efeito biológico. Isto porque há inumeras vias celulares reguladas pelo estado redox celular, onde a perturbação destas vias pode contribuir para morte celular. $\mathrm{O}$ uso de concentrações mais altas dos compostos antioxidantes poderia neste caso interferir nestas vias. Contudo, por outro lado, não houve diferença no padrão de morte celular nas situações controle, onde a mesma concentração foi usada, abrindo a possibilidade de que as alterações nos padrões de morte observadas podem refletir um efeito biológico destas espécies frente à UVB.

O uso de Tempol, molécula que mimetiza a ação de enzimas superóxido dismutase, atua na dismutação de ânions superóxidos que são moléculas altamente reativas. Foi possível observar que o uso de concentração mais alta de Tempol levou a maior sensibilidade à UVB em Skmel-37 e um aparente aumento também em Skmel-28, embora não significativamente estatístico. A questão que paira é justamente qual o papel dos ânions superóxidos, onde sua neutralização leva a maior sensibilidade. Parte desta pergunta pode ser respondida pelos resultados apresentados pelo trabalho de Nazarewicz e colaboradores (Nazarewicz et al., 2013). Neste trabalho, inclusive usando melanomas, os autores verificaram que o uso de Tempol (mais precisamente molécula dirigida à mitocôndria) modulava a quantidade de superóxido e este por sua vez alterava a via de AKT, a qual modulava a sobrevivência celular. Já outro trabalho, indicou que ânions superóxidos podem ativar as vias Ras e Rac1 em melanomas, as quais também estão relacionadas a sobrevivência (Molognoni et al., 2013). Baseando-se nos achados de outros trabalhos podemos sugerir que o uso de Tempol e a consequente diminuição nos níveis de superóxido podem também ter interferido nas vias Ras/AKT, alterando assim a sobrevivência das células após UVB. A comprovação da alteração da ativação 
destas vias após UVB/Tempol pode ser interessante no intuito de caracterizar as vias moleculares que possam permitir a sobrevivência celular após doses de UVB.

Da mesma maneira que no uso de Tempol, o uso de Catalase também alterou a sobrevivência das linhagens após UVB. Em ambas as linhagens, o uso de maior concentração aumentou a sensibilidade. Só que de maneira mais curiosa que no uso de Tempol, a adição de Catalase se deu apenas com a enzima não adicionada a nenhum composto que permitisse sua entrada no citoplasma celular, ou seja, seu efeito deu-se apenas em nível extracelular. Peróxidos de Hidrogênio, principal substrato de Catalase, também esta relacionado a diversas vias de sinalização intracelular atuando tanto como molécula reativa causando danos celulares como também modulando vias de sobrevivência celular como PI3K/AKT (Gough \& Cotter; 2011). Adição extracelular de Catalase já foi demonstrada como efetora de alterações em importantes vias celulares como ERK e JNK-1 (Preston et al., 2001). Por sua vez, a via de JNK-1 também se mostra envolvida com processos de sobrevivência e morte celular (Sui et al., 2014). Desta maneira podemos sugerir que o resultado obtido com utilização de Catalase é que sua ação no processo de neutralização de peróxidos de hidrogênio de maneira extracelular acabe por alterar a via de ERK e principalmente JNK, contribuindo para maior sensibilidade à UVB.

Os resultados deste primeiro corpo de resultados trás então uma análise mais compreensível das vias moleculares que podem estar envolvidas com o processo carcinogênico de melanomas associado com exposição à UVB, indicando o papel de p53 na modulação da atividade de XPC e na resposta à UVB e também o possível papel anti-apoptótico que espécies reativas de oxigênio podem ter neste contexto. Como discutido acima, p53 pode ter papel importante neste cenário, onde sua funcionalidade 
pode atuar de maneira distinta seja nos processos iniciais de exposição quanto à progressão da transformação.

No que se refere a transformação, os dados da literatura mostram que, embora não mutada, a funcionalidade de p53 esteja diminuída e apresente baixo nível transcricional de seus alvos (Houben et al., 2011). Essa baixa atividade transcricional de p53 em estágios mais avançados de melanomas apresenta vantagens aos clones celulares uma vez que este processo transcricional ativa uma diversidade de outras proteínas relacionadas tanto a parada do ciclo celular e processos de morte, fenômenos estes que podem agir negativamente para o crescimento da população de células tumorais.

Seguindo esta linha de evidências, o próximo passo que esta tese buscou avaliar era a possível relação do papel de p53 como via moduladora de GGR-NER na resposta à cisplatina, um agente quimioterápico comumente usado no tratamento, mas com baixa taxa de resposta. O papel da via NER na resposta a cisplatina tem sido controverso (Bowden, 2014), contudo existe não só a heterogeneidade entre os estudos, devido a metodologias, como também a heterogeneidade que existe entre os tipos de tumores, o que de certa forma pode influenciar nos resultados finais. Para melanomas, tal correlação entre sensibilidade à cisplatina e modulação da via GGR-NER foi pouco explorada (Bowden et al., 2010). Além disso, a existência de duas linhagens de melanoma com funcionalidade diferencial de p53 possibilita explorar não só seu papel na modulação da via GGR-NER frente aos danos por cisplatina, como também seu papel direto na resposta a tais danos. Para responder a estas questões, um corpo de resultados foi apresentado nesta tese e agora discutido. 
Os resultados apresentados, em primeiro lugar, demonstram que em linhagens onde p53 apresenta funcionalidade, apresentam maior sensibilidade à cisplatina. Isto pode ser visto através de ensaios de morte celular, sobrevivência por ensaio clonogênico, uso de pifithrin- $\alpha$ e até por ensaio com linhagem Skmel-28 transduzida com p53. A relação existente entre resposta à cisplatina e status e expressão de p53 já tem sido descrita em diversos tipos de tumores (Ali et al., 2012; Bellmunt et al., 2013; Cavallo et al., 2013). A maioria dos estudos que demonstram o papel de p53 na sensibilidade à cisplatina reporta que esta relação é baseada na habilidade de p53 em transcrever genes relacionados aos processos de morte celular. Assim como mostrado para os resultados para UVB, a linhagem Skmel-37 se mostrou mais capaz em expressar PUMA $\alpha / \beta$, importante proteína downstream de p53 e envolvida com o processo de morte celular. Tanto para a transdução de p53 em Skmel-28 e também na comparação entre as linhagens Mewo e SBCL-2, a expressão de PUMA $\alpha / \beta$ foi maior quando p53 se apresentava funcional. A relação entre a expressão de PUMA $\alpha / \beta$ e morte celular por cisplatina já tem sido descrita também (Yuan et al., 2012), sendo que desta maneira é possível especular que a morte por cisplatina observada em linhagens com p53 funcional seja mediada principalmente pela expressão de PUMA $\alpha / \beta$, embora a comprovação experimental de tal sugestão não tenha sido realizada neste corpo de resultado.

Os resultados apresentados demonstram primeiramente a via p53-PUMA $\alpha / \beta$ como importante para a sensibilidade à cisplatina. No entanto, outros resultados obtidos ajudam a entender a complexa rede de vias que podem estar relacionada à resistência a tal quimioterápico. Um dos marcadores mais representativos no que diz respeito a sensibilidade à cisplatina é a expressão de ERCC1 (Martin et al., 2008), uma proteína 
acessória da via NER (Figura 2) e que também está relacionada a vias de reparo de adutos que causam cross-links entre fitas de DNA (interstrand cross-links)(Klein Dowell et al., 2014). A expressão de ERCC1 tem sido relacionada a resistência à cisplatina e tem sido usada continuamente como importante marcador para prognóstico em diversos tipos de tumores, como por exemplo câncer esofágico (Bharthuar et al., 2014), ovário (Muallem et al., 2014), cabeça e pescoço (Bauman et al., 2013) e diversos outros (Altaha 2004). Na maioria dos estudos citados e outros que fazem referência entre a expressão de ERCC1 e resistência à cisplatina se baseia na expressão da proteína em relação ao tecido tumoral em questão, sendo poucos os estudos in vitro. Em linhagens de câncer colorectal, aumento da expressão de ERCC1 foi correlacionado com maior atividade de reparo de adutos causados por cisplatina e menores efeitos citotóxicos (Arnold et al., 2003). A teoria que se baseia na relação entre ERCC1 e cisplatina está mais relacionada a seu papel junto com XPF na resolução de forquilhas de replicação frente a lesões e adutos que causam cross-links entre fitas de DNA, onde tais estruturas são resolvidas por endonucleases, sendo esta a função de XPF-ERCC1 (Zhang \& Walter, 2014). Nesta relação, a maior expressão de ERCC1 estaria correlacionada a maior eficiência na resolução de adutos causados por cisplatina e consequentemente menor sensibilidade. Em melanomas, o estudo desenvolvido por Li \& Melton (Li \& Melton, 2012), demonstrou que há aumento de expressão de ERCC1 após estimulo com cisplatina, onde tal regulação é mediada por via ERK e relacionada à sensibilidade ao quimioterápico.

Embora exista um forte relato na literatura desta relação de ERCC1 e cisplatina, nos resultados obtidos aqui apresentados, a expressão de ERCC1 não se mostrou correlata com sensibilidade, uma vez que em Skmel-37 sua expressão era maior que em 
Skmel-28. Nos resultados apresentados, também não se observou uma relação direta entre a exposição à cisplatina e aumento de expressão e alteração na via de ERK-2, o que sugere que outras vias podem modular a expressão de ERCC1, e a sensibilidade à cisplatina, como por exemplo, p53. Independente da expressão de ERCC1 e sua possível atuação em forquilhas de replicação colapsadas por lesões causadas por cisplatina, tal fenômeno parece de fato estar relacionado ao efeito citotóxico do quimioterápico. A inibição do ciclo celular por privação de soro demonstrou que a diminuição da quantidade de células entrando em fase S-G2-M do ciclo celular diminuição a quantidade de morte celular após cisplatina. Neste sentido, a não entrada na fase $\mathrm{S}$ do ciclo acarreta menor quantidade de forquilhas de replicação colapsadas pela presença de danos, levando a menor taxa de morte celular. Estes resultados expõe a importância das forquilhas de replicação e seu reparo em caso de lesões como importante componente do binômino sensibilidade/resistência à agentes quimioterápicos em melanomas e diversos outros tumores. Expressão de proteínas de reparo e replicação de DNA envolvidas justamente com resolução de forquilhas colapsadas foi atribuída ao sucesso de metástase e quimiorresistência em melanomas (Kauffmann et al., 2008).

Os resultados apresentados desenham um possível cenário que contribui para o entendimento de um dos mecanismos de resistência à quimioterapia apresentada por melanomas. A inibição da funcionalidade de p53 observada em melanomas em estágios mais avançados permite aos clones celulares da massa tumoral a vantagem de serem mais resistentes aos danos causados pela exposição à cisplatina, onde o desencadeamento do processo de morte celular ativado por p53 se encontra inibido. Não apenas esta característica, mas também uma taxa replicativa menor de determinado grupo de células pode diminuir a citotoxicidade do quimioterápico, permitindo assim a 
manutenção de células com capacidade de resistência e capazes de repopulação tumoral. Os resultados apresentados pelo ensaio utilizando-se Skmel-28 GFP e Skmel-28 p53 ilustrou justamente esta situação.

Ao buscarmos simular in vitro a heterogeneidade de funcionalidade de p53 em uma massa tumoral, foi possível observar que a população apresentando baixa funcionalidade de p53 (GFP) se sobressaiu em relação à população com maior funcionalidade de p53 (p53), sugerindo que em uma situação in vivo, clones com tais características acabam por ser positivamente selecionados. Compreendendo esse fitness que a heterogeneidade tumoral pode proporcionar, é possível propor e testar diferentes metodologias para aumentar a taxa de sensibilidade de células resistentes à quimioterapia.

Dentre estas proposições, o que se tem discutido é a possibilidade de reativação da atividade de p53 mediante pequenas moléculas ativadoras ou mesmo inibidores específicos com alvo nos inibidores naturais celulares de p53, bem como da via de p53 (Shen \& Maki, 2011). Um dos principais alvos destas novas moléculas é a proteína HDM-2 (ou sua ortóloga MDM-2 em camundongos), cuja uma das principais funções está em ubiquitinar p53, levando-a a degradação via proteassoma (Golubovskaya \& Cance, 2013). HDM-2 e também HDM-4 são conhecidos como os maiores inibidores de p53, onde a atuação destes inibe a atividade transcricional de p53, considerada a principal habilidade supressora da proteína. HDM-2 e HDM-4 são comumente encontrados amplificados em tumores humanos, inclusive em melanomas (Polsky et al., 2002; Muthusamy et al., 2006) e, adicionalmente, a inativação de p53 em melanomas pode ser adquirida através de mutações no locus $\mathrm{CDKN} 2 \mathrm{~A}$, a qual produz a proteína p14 e p16. P14 atua na ativação de p53 por inibir a atividade de HDM-2, sendo que no 
caso de mutações ou mesmo deleções do locus CDKN2A, p14 perde sua habilidade em inibir HDM-2 levando como consequência a inativação de p53.

Com a descoberta de pequenas moléculas capazes de inibir a atividade de HDM2 e consequentemente restaurar a atividade de p53, diversos estudos têm usado tais moléculas com o propósito de demonstrar a possibilidade de seu uso na clinica. Neste contexto, a molécula inibidora mais conhecida é Nutlin-3, a qual especificamente interrompe a interação entre HDM-2 e p53 por se ligar ao domínio de interação entre estas duas proteínas e a qual permite a ubiquitinação de p53 (Vassilev et al., 2004). Como resultado, Nutlin-3 pode estabilizar p53 em células com alta expressão de HDM2 e consequentemente regular a expressão de genes alvos downstream de p53 como, por exemplo, p21, PUMA $\alpha / \beta$ e demais proteínas. A habilidade de Nutlin-3 em suprimir o crescimento tumoral e aumentar a sensibilidade a quimioterápicos têm sido demonstrado em diversos estudos, inclusive estudos pré-clínicos (revisado em Shen \& Maki, 2011).

Com estas informações, testou-se o possível efeito de Nutlin-3 na sensibilidade à cisplatina. Os resultados indicaram que o uso de Nutlin-3 pode de fato aumentar a sensibilidade das linhagens testadas, independentemente do status funcional de p53. Isto pode ser observado tanto nas linhagens Skmel-28 e Skmel-37, quanto nas linhagens SBCL2 e Mewo, indicando um efeito positivo do uso do composto. No entanto, os resultados não demonstram um efeito concentração- dependente. Isto porque em concentração menor, Nutlin-3 aumentou a sensibilidade para morte celular, no entanto, em concentração maior, os efeitos foram diversos, mostrando diferenças entre as linhagens. Em um primeiro momento, podemos associar os resultados a atividade de Nutlin-3 em inibir a interação HDM-2-p53, liberando esta última para transcrever genes 
associados à morte celular, como por exemplo, PUMA $\alpha / \beta$. Se desta maneira ocorreu, os resultados denotam que a possibilidade de se usar pequenas moléculas inibidoras da interação HDM-2-p53 é algo que de fato possa vir a ser explorado no futuro como metodologia adjuvante ao tratamento quimioterápico de melanomas. Para outros tipos de tumores como leucemias (Coll-Mulet et al., 2006), mielomas (Stuhmer et al., 2005), carcinoma de laringe (Arya et al., 2010), o uso de Nutlin-3 também mostrou efeitos animadores quanto a seu uso em terapias.

Além de inibir a interação de HDM-2 e p53, o uso de Nutlin-3 também pode alterar outras vias dependentes de HDM-2 tendo como consequência a inibição do crescimento tumoral. Por exemplo, o uso de Nutlin-3 também pode, via HDM-2, ativar a ação de p73 e E2F-1, cuja ação também pode levar a ativação de proteínas próapoptóticas como PUMA $\alpha / \beta$ e NOXA, principalmente em células mutantes ou deletadas para p53 (Ambrosini et al., 2007; Lau et al., 2008; Pierce \& Findley, 2009). Como nestes estudos citados, houve uso de linhagens mutantes para p53, podemos sugerir que o uso de Nutlin-3, principalmente nas linhagens Skmel-28 e Mewo (sabidamente p53 mutantes), também possa ter operado através das vias de p73 e E2F-1. Independentemente da via na qual tenha exercido seu efeito, embora a descrição dos mecanismos seja de grande importância e, no entanto não explorada no corpo de resultados, o uso de Nutlin-3 se mostrou eficiente na sensibilidade à cisplatina. Não apenas o uso de Nutlin-3, mas o desenvolvimento de outras drogas inteligentes que atuem na interação HDM-2-p53 tem tido efeitos promissores como potenciais moléculas para uso em clinica (Shangary \& Wang, 2009).

Por fim, os resultados também mostram que XPC também está envolvido com resistência à cisplatina. O uso de RNA de interferência para XPC aumentou a 
sensibilidade ao quimioterápico. Primeiramente, é possível discutir a função de XPC e consequentemente da via GGR-NER no reparo/resistência à cisplatina. Este tópico tem sido extensivamente discutido na literatura, onde é possível verificar estudar que sugerem a participação de XPC (Lee et al., 2014; Barckhausen et al., 2014) enquanto outros sugerem que não (Bowden et al., 2010; Enoiu et al., 2012). De qualquer maneira, XPC também mostrou expressão dependente de p53 em cisplatina, pontuando este último como modulador da atividade de XPC por controle de sua expressão. Contudo, os resultados sugerem que o processo de morte desencadeado por p53 durante a exposição à cisplatina é maior do que a resistência que a expressão de XPC possa oferecer, resultado também sugerido por Barckhausen e colaboradores (Barckhausen et al., 2014). Neste sentido, a inibição da atividade de XPC também pode ser desenvolvida com o intuito de aumentar a sensibilidade à cisplatina.

O corpo de resultados apresentado para a sensibilidade à cisplatina em melanomas mostra que p53 apresenta um papel fundamental nesta relação, seja na ativação de vias de morte celular seja também na expressão de proteínas de reparo que possam ter influência como, por exemplo, XPC. Baseando-se nos dados de que em melanomas a atividade de p53 esta suprimida, esta pode ser uma das vias moleculares que contribuem para a resistência apresentada por este tipo de neoplasia. A melhor elucidação dos mecanismos que modulem da atividade de p53 e também da atividade de reparo de DNA pode contribuir no intuito de se buscar novas alternativas de tratamento ou melhoria nas respostas das terapias já conhecidas. Um dos fatores que possa estar envolvido, e justamente modula a atividade de p53 e XPC é a proteína hHR23B a qual também foi estudada nesta tese e cujos resultados são discutidos abaixo. 
5.2 Relação de hHR23B com o desenvolvimento de melanoma e sua atividade na modulação de XPC

HHR23B tem sido inicialmente descrito como gene relacionado ao reparo de DNA, mais precisamente na via de reparo NER, onde atua como proteína acessória no reconhecimento de lesões através de sua interação com XPC (Clement et al., 2010). Os resultados mostrados podem ser importantes no que se refere à possível participação de hHR23B na biologia de melanomas. Primeiramente, o dado que chama a atenção é a diversidade e heterogeneidade de expressão de hHR23B em diferentes fases da progressão de melanoma.

Embora, esse dado seja até o momento inédito para amostras de pacientes, a diferenças da expressão de hHR23B já haviam sido demonstrada em linhagens de melanoma (Sousa \& Espreafico, 2008). Da mesma maneira, nas linhagens utilizadas no projeto, foi possível verificar o mesmo acontecimento de perda de diminuição de hHR23B. Tanto os resultados apresentados, quanto alguns descritos na literatura, sugerem que a baixa expressão de hHR23B possa estar relacionado a biologia do melanoma humano.

Após verificar a baixa expressão de hHR23B nas linhagens de melanoma, uma possível explicação de tal poderia ser eventos relacionados à metilação do promotor. Uma vez metilado em suas ilhas CpGs, este processo desencadeia o recrutamento de diversas proteínas que alteram a estrutura da cromatina, inviabilizando assim o acesso de fatores de transcrição a região promotora (Deaton \& Bird, 2011). Os ensaios com agente inibidor de DNA metil transferases (5'AZA), demonstram que o promotor possa realmente estar metilado. Embora não se tenha os resultados que demonstrassem se (e quais) ilhas CpGs da região promotora estão de 
fato metiladas, resultados na literatura já demonstraram que hHR23B possui um promotor passível de metilação e que esta metilado em tumores (Peng et al., 2005). Levando em conta esta possibilidade de perda de expressão por metilação, pode-se sugerir que este mecanismo também pode influenciar a heterogeneidade de expressão vista em nevus e melanomas primários, a partir das amostras contidas no TMA.

Como a perda de hHR23B mostra-se um evento comum a alguns melanomas, foi possível verificar sua funcionalidade nas linhagens LB373, Mel-85 e Skmel-37. Inicialmente, buscou-se avaliar o papel de hHR23B no processo de reparo de DNA via NER. Todos os dados apresentados até o presente momento se mostram dados confirmatórios, uma vez que o papel de hHR23B no reparo de DNA já é descrito (Ng et al., 2003; Okuda et al., 2004, Dantuma et al., 2009). No entanto, devido a relação entre danos causados por UVB e carcinogênese de tumores cutâneos, é sugestivo dizer que a perda de hHR23B pode ser um dos eventos iniciais que contribuem para a carcinogênese de melanócitos, originando-se assim os melanomas. Neste cenário de baixa expressão de hHR23B, o reparo de lesões causadas por exposição à UV pode ficar comprometido devido a sua função em auxiliar na atividade de reparo exercida por XPC. Os resultados mostrados nas linhagens LB373 e Mel-85 mostraram que a expressão de XPC é menor em comparação à linhagem Skmel-37 após UVB, muito provavelmente devido a sua menor estabilidade, resultado este que foi demonstrado pelo uso de cicloheximida. Com esta menor estabilidade, a atividade de reparo iniciada por XPC em GGR-NER pode ser alterada ou diminuída, tendo como consequência final a menor capacidade de reparo frente a lesões UVB, permitindo que mutações carcinogênicas possam ser fixadas. Mutações típicas de UV, como transições de Citosinas para Timinas, têm sido descritas em trabalhos que avaliam o genoma 
completo de um melanoma (Pleseance et al., 2010), bem como genes específicos em amostra de pacientes (Wang et al., 2009).

No entanto, a influência de XPC no reparo de lesões também pode ser modulada via regulação transcricional. Recentes dados da literatura identificaram motifs p53 dependentes na região promotora de XPC (Hastak et al, 2012). Assim, a menor expressão de XPC nas linhagens ausentes para hHR23B poderia ser decorrente de menor atividade de p53. No entanto, todas as linhagens de melanoma demonstraram expressar p53, além de também expressarem DDB-2, importante proteína que atua auxiliando XPC no processo de reconhecimento de lesões do tipo CPD (Fitch et al., 2003). Porém, os resultados também mostraram a relação existente entre os níveis de expressão de hHR23B e a estabilidade de p53. Isto porque, hHR23B já foi descrito como proteína atuante na regulação e estabilidade de p53 (Kaur et al., 2006), trabalho este que mostrou que células knock-down para hHR23B apresentavam p53 com menor funcionalidade, com respeito a sua atividade transcricional de p21, além de menor nível de ubiquitinação.

Considerar que de fato hHR23B também exerce função na estabilidade e funcionalidade de p53 pode trazer grande contribuição no entendimento da biologia dos melanomas. Isto porque p53, que costuma estar envolvido no processo de carcinogênese de diversos tumores e esta frequentemente mutado em mais de $50 \%$ dos tumores (Benjamin et al., 2008), é geralmente descrito como ausente de mutações em melanomas. Neste caso, embora não esteja mutada, a via de p53 pode estar comprometida em seu total funcionamento devido a falta de expressão de hHR23B. Alguns estudos mostram diferentes funções de padrões de ubiquitinação em p53, sendo o mais descrito o processo de ubiquitinação para degradação via interação de p53 com 
HDM-2 (Hock \& Vousden, 2014).

No entanto, é importante ter em mente que as comparações feitas entre linhagens possuem alguns viéses, uma vez que são linhagens tumorais, das quais muitas alterações moleculares podem existir. Dentre esta diversidade de alterações moleculares, muitas das quais não se pode avaliar, a real função da falta de hHR23B pode estar mascarada por tais alterações. Assim, a inibição de hHR23B apenas poderia nos dar maior confiança de seu papel na biologia dos melanomas.

Para confirmação do papel de hHR23B, optou-se por usar silenciamento transiente através de siRNA. Neste caso, pequenas sequências específicas complementares ao RNA alvo são transfectadas nas linhagens, onde o mecanismo de RNA de interferência mediado pelo complexo proteico RISC, usa estes moldes de siRNA para levar a degradação do mRNA mensageiro alvo, caracterizando-se assim o efeito de knock-down gênico (Alberts et al., 2008). Desta maneira, nós optamos por usar siRNA primeiramente na linhagem Skmel-37.

Através do uso de siRNA para hHR23B, nós podemos confirmar em Skmel-37 os resultados para LB373 e Me185 previamente mostrados nestas linhagens de que a baixa expressão de hHR23B esta relacionada a menor taxa de reparo de DNA, sugerindo que esta menor taxa esteja envolvida com a modulação da atividade de XPC, como já anteriormente descrito (Ng et al., 2003; Okuda et al., 2004). Usando MEF's (mouse embryonic fibroblasts) de camundongos Knock-out para mHR23B, mostrou que tal ausência da proteína leva a menor eficiência de reparo, menor estabilidade de XPC quando usado o inibidor de tradução cicloheximida, e menor expressão quando as células são expostas a UV (Okuda et al., 2004). 
Os mesmos resultados de sensibilidade a UV devido a menor expressão e estabilidade de XPC foi descrita também para células humanas (Renaud et al., 2011). Neste trabalho, utilizando-se células HeLa estavelmente transfectadas para expressarem shRNA para hHR23B em plasmídeos EBV (Epstein-Barr Vírus), verificou-se que a inibição levava a menor expressão de XPC, e também diminuía a capacidade de reparo de DNA. Nossos resultados também chegam à mesma evidência do papel de hHR23B em linhagens de melanoma. Tomando a visão geral do projeto, os resultados sugerem que o papel de hHR23B no reparo de DNA via XPC é importante na supressão de lesões por UV na biologia dos melanomas.

Os resultados até aqui evidenciam que a falta de hHR23B leva a menor expressão e estabilidade de XPC, e que este resultado pode ter influência na eficiência de reparo de DNA, que, embora sensibilize as células a morte, ao mesmo tempo pode permitir a aquisição de mutações, o que em um contexto de biologia de melanócitos, contribui para o processo carcinogênico.

Essa relação de diminuição na atividade de reparo de DNA frente a danos causados por UV contribui para aquisição de mutações potencialmente carcinogênicas. De fato, alta taxa de mutações do tipo UV tem sido descritas em amostras de melanomas (Pleasance et al., 2010; Krauthammer et al., 2012). Uma análise mais detalhada do genoma destes melanomas pontua que a maioria das mutações do tipo UV encontradas nos melanomas se localizam em regiões não transcritas do DNA (Pleasance et al., 2010). Justamente, nestas regiões não transcritas do DNA que o complexo XPChHR23B atua, caracterizando-se assim o GGR-NER (Costa et al., 2003). Tal junção de evidências demonstra que a modulação do reparo de DNA via moduladores da função 
de XPC, como por exemplo, a expressão de hHR23B pode estar relacionada no processo de carcinogênese de melanócitos.

Outro fato que demonstra tal relevância foi a menor atividade de reparo vista nas células Skmel-37 quando inibidas para hHR23B. De interessante foi observar o fato que apenas o reparo de lesões do tipo fotoproduto 6-4 foi significantemente alterada. Por outro lado, a inibição de hHR23B não modificou a taxa de reparo de lesões CPD, embora o silenciamento de XPC tenha alterado tal resposta. Para tais resultados algumas interpretações podem ser levantadas: primeiramente, é possível relacionar a falta de diferença entre a taxa de reparo de lesões CPD como efeito da eficiência de silenciamento de hHR23B. Como pode ser observado, o uso de siRNA para hHR23B obteve uma redução no mRNA de hHR23B de aproximadamente $70 \%$, fato que pode ser atribuído a dificuldade de transfecção de melanomas (fato esse já observado por outros membros do grupo que trabalham com Skmel-37 ou outras linhagens). Neste caso, um modesto silenciamento de hHR23B pode não alterar profundamente a funcionalidade de XPC no reconhecimento de lesões do tipo CPD.

Já a segunda interpretação pode estar relacionada também ao próprio processo de reconhecimento de lesões causadas por UV. Isto porque, estruturalmente, lesões do tipo CPD causam menor distorção da fita de DNA em comparação com as lesões do tipo fotoproduto 6-4 (Clement et al., 2010), e tal fato tem implicação direta nos resultados aqui apresentados. Como as lesões CPD apresentam baixa distorção do DNA, seu reconhecimento direto por XPC é menor quando comparado com os fotoprodutos 64, sendo neste caso a necessidade da atuação do complexo formado pelas proteínas DDB1 e DDB2, os quais têm maior facilidade de ligação à CPDs, auxiliando assim o recrutamento de XPC e a posterior correção da lesão via NER (Clement et al., 2010). Já 
no caso dos fotoprodutos 6-4, devido a grande distorção no DNA que tais lesões causam, permitem o reconhecimento direto de XPC. Assim, os resultados aqui apresentados mostram que a inibição de hHR23B compromete principalmente o reconhecimento das lesões do tipo fotoproduto 6-4, sendo, no entanto não alterar significativamente o reconhecimento das lesões CPDs. No entanto, não se pode afirmar que não há relação entre a baixa expressão de hHR23B e o reconhecimento de lesões CPDs, tidas como mais freqüentes e mais carcinogênicas (Clement et al., 2010). Uma maior eficiência no silenciamento de hHR23B, como por exemplo, o estabelecimento de uma inibição estável de shRNA, pode demonstrar que o reparo de CPDs também se compromete.

A funcionalidade de hHR23B no reparo de DNA não se restringe apenas a manutenção da estabilidade de XPC por proteção contra a degradação proteassomal. Estudos demonstram que o reconhecimento e ligação de XPC ao DNA lesado é dependente de sua dissociação de hHR23B (Bergink et al., 2012). Com este trabalho os autores propõe que após o reconhecimento, hHR23B expõe os sítios de ligação de XPC ao DNA lesado através de sua dissociação, permitindo assim a XPC se ligar estavelmente às lesões. Neste sentido, hHR23B atuaria de maneira a endereçar XPC de maneira estruturalmente correta ao DNA lesado, onde essa dissociação favorece a um binding mais estável, permitindo também estabilização da proteína na ausência de hHR23B nesta situação de binding (Bergink et al., 2012).

É possível que nesta situação acima descrita, onde hHR23B atua no binding de XPC ao DNA lesado, que possa ser relacionado o papel de hHR23B-XPC no reparo de lesões causadas por UV e também, como por exemplo, doxorrubicina. Trabalhos anteriores têm mostrado o papel de XPC na sensibilidade à doxorrubicina, sugerindo 
assim participação da via NER no reparo deste tipo de lesão (Saffi et al., 2010; Carvalho et al., 2010). O papel de hHR23B e XPC no reparo de lesões causadas por doxorrubicina pode ser evidenciado nos resultados de silenciamento nas células Skmel37. No entanto, quando se optou por usar as linhagens LB373 e Mel85, as quais não expressam hHR23B, pode-se notar que não existiu uma correlação linear entre a expressão de hHR23B e a sensibilidade à doxorrubicina, uma vez que Skmel-37 que expressa normalmente hHR23B apresentou sensibilidade intermediária. Diferentemente das lesões UV que só acometem a estrutura física do DNA através das lesões, doxorrubicina pode apresentar outros efeitos além de adutos, como por exemplo, atuando na inibição de topoisomerases e produção de espécies reativas (Minotti et al., 2004). Assim, é possível especular que outras vias de reparo ou condições que possam influenciar na resposta à doxorrubicina, pontuando assim um papel secundário da via NER na resistência a este quimioterápico.

Alguns resultados quanto a sensibilidade alterada pelo silenciamento de hHR23B chamam a atenção. Tanto para cisplatina quanto para temozolomida, não houve alteração na sensibilidade quanto a diminuição da expressão de hHR23B. No entanto, para a silenciamento de XPC, houve maior sensibilidade à cisplatina. O papel de XPC no reparo de cisplatina tem sido controverso na literatura (Eniou et al., 2012, Lai et al., 2011), no entanto, o papel de hHR23B na atuação de facilitar o processo de reparo de XPC pode atuar na mesma maneira que o descrito para lesões CPDs.

Os resultados para a exposição tanto a etoposídeo quanto para tunicamicina chamam a atenção para possíveis funções de hHR23B sem participar diretamente do complexo hHR23B-XPC, isto porque o silenciamento de XPC não alterou a sensibilidade a estas drogas. Em ambas as drogas pode-se perceber menor taxa de morte 
celular após $48 \mathrm{~h}$ de tratamento. De fato, para tratamento com etoposídeo, menor taxa de morte e maior viabilidade pode ser vista em células silenciadas para hHR23B (Kaur et al., 2007). Neste caso em específico, se mostrou que o silenciamento de hHR23B era acompanhado com menor indução de proteínas envolvidas com processo de morte celular, como por exemplo BAX. Esta menor sensibilidade na verdade se mostrou decorrente de uma menor estabilidade de p53 na vigência do silenciamento de hHR23B, o que em consequiência diminuiria a expressão de proteínas downstream, como BAX e p21. No mesmo caso para o tratamento com tunicamicina, a indução de estresse de retículo pode levar a ativação de processos de morte p53-dependentes (Lin et al., 2012), onde a baixa expressão de hHR23B pode atenuar tal resposta a morte, da mesma maneira que para etoposídeo.

Como o foco principal do trabalho esta na relação de hHR23B na resposta a danos por UVB, além do processo de morte celular, foi vista a capacidade das células previamente irradiadas em formar colônias, o que a longo prazo indica a capacidade das células em receber o dano, corrigi-lo e continuar a se multiplicar. O mesmo efeito de atenuação de morte celular após $48 \mathrm{~h}$ de exposição em células silenciadas para hHR23B também pode ser observado na dose de $120 \mathrm{~J} / \mathrm{m}^{2}$. Tal efeito de atenuação de morte por UV em células silenciadas para hHR23B também foi visto previamente (Kaur et al., 2007), novamente por um mecanismo atenuador da função de morte celular dependente de p53. No entanto, os dados sobre ensaio clonogênico mostraram que essa relativa maior sobrevivência das células após $48 \mathrm{~h}$ de exposição não se reflete na capacidade de sobrevivência e crescimento clonogênico em longo prazo. Diante destes resultados é possível pressupor que a inibição parcial de hHR23B pelo uso de siRNA possa em um primeiro momento atenuar a resposta a morte induzida pelas lesões $\mathrm{UV}$, contudo a 
longo prazo, o não reparo eficiente destas lesões (como sugerido pelos ensaios de dot blot) possa inviabilizar a sobrevivência das células a longo prazo, como visto pelos resultados do clonogênico.

Porém, nas linhagens LB373 e Mel85 que apresentam baixa expressão de hHR23B, a atenuação de morte pode não sobrepor a deficiência de reparo de lesões, levando assim a morte das células. Novamente, devido às diferenças genéticas inerentes das linhagens, outras variáveis podem estar envolvidas na sensibilidade a UVB. Já com relação aos resultados obtidos pelo uso de siRNA contra XPC só confirmam a importância deste gene no reparo de lesões causadas por UV, pois a diminuição de sua expressão acarreta em menor atividade de reparo de DNA e consequentemente à maior sensibilidade. Por fim, o que os dados até o presente sugerem é que possa haver outras funções de hHR23B além de sua participação na via NER participando do complexo hHR23B-XPC-centrin-2 no reconhecimento de lesões, uma vez que em alguns casos, sua diminuição de expressão contribui para uma menor taxa de morte para determinadas drogas.

5.3 Expressão alelo-específica de XPC e sua influência na modulação na atividade gênica

Expressão diferencial de alelos gênicos tem sido descrita por alguns trabalhos analisando o padrão de expressão do genoma humano (Lo et al., 2003; Morley et al., 2004). Variantes polimórficas podem exercer sua função na regulação da expressão gênica de maneira cis ou trans, onde a primeira atua apenas na região cromossômica na qual ele esta inserido. Neste caso, um polimorfismo-cis em heterozigose pode resultar em uma expressão alelo-específica (ASE), contribuindo para a expressão diferencial de 
um alelo em comparação a outro. Quando em situação trans, tal variante polimórfica acaba por influenciar a expressa gênica de outras regiões cromossômicas e genes (Doss et al., 2005).

Amostras originalmente heterozigotas têm sido usadas como modelos para quantificação de expressão alélica específica (Babak et al., 2010). Isto porque, se espera que não apenas exista uma relação de 1:1 entre as formas alélicas, como também estejam sujeitas a mesma condição de expressão e controle transcricional. Diferentes metodologias já foram empregadas para quantificação específica de alelos, variando desde o uso de tecnologias mais recentes como o sequenciamento massivo de RNAs (RNA seq) (Babak et al., 2010), ou através de metodologias baseadas em PCR em tempo real, com o uso de sondas específicas, como metodologia Taqman (Lubbe et al., 2012; Pillay et al., 2012).

Como o objetivo do projeto é analisar os fatores que podem modificar a atividade de XPC e assim contribuir para o processo de carcinogênese de melanomas, a avaliação de possíveis funções de variantes polimórficas existentes no gene XPC também se encaixa na proposta. Estes polimorfismos já foram associados ao maior risco de desenvolvimento de melanomas (Gonçalves et al., 2011), e a exploração da possível funcionalidade destes polimorfismos tanto em relação a estabilidade do RNA mensageiro quanto à função protéica propriamente dita (devido ao polimorfismo K939Q), também foram explorados.

A primeira hipótese quanto ao possível papel dos polimorfismos de $X P C$ poderia ser em relação à estabilidade do mRNA. Isto porque $X P C$ possui dois polimorfismos intrônicos os quais poderiam de alguma forma, alterar a estabilidade do transcrito, como por exemplo, atuando em processos de splicing. De fato, o polimorfismo existente no 
sitio aceptor de splicing do exon 12 (XPC IV11 -6 A/C) tem potencial para alterar o processo de splicing, levando uma porcentagem do transcrito a perder o exon $12 \mathrm{e}$ consequentemente apresentar menor estabilidade (Khan et al., 2002). Devido a fato de estes dois polimorfismos estarem em forte desequilíbrio de ligação, junto com o polimorfismo K939Q localizado no exon 15, seria possível avaliar a expressão aleloespecifica tomando o alelo K939Q como marcador surrogado do possível papel dos outros polimorfismos. Além disso, para o alelo K939Q já existiam sondas específicas para a genotipagem destes polimorfismos.

Curiosamente, os resultados apresentados demonstraram que de maneira geral, o alelo $\mathrm{Q}$ esteve mais expresso que o alelo $\mathrm{K}$ na maioria das linhagens utilizadas, com exceção de Skmel-37. Desta maneira, os resultados sugeriram que a presença dos polimorfismos intrônicos não altera significativamente a estabilidade do mRNA de XPC no sentido de diminuí-la, seja pela possível perda do exon 12 ou por outros mecanismos não descritos e que possam ser atribuídos a tais polimorfismos. O cenário mais provável é de que existam outros fatores envolvidos na regulação da expressão alelo-específica de XPC. De fato, mecanismos de regulação da transcrição podem estar envolvidos. Estes possíveis mecanismos de regulação podem ter papel importante na expressão alelo-especifica, visto que entre as linhagens, o padrão de expressão total de XPC já apresentou variações. Um destes moduladores de expressão de $X P C$ pode ser a proteína p53, como já demonstrado pelos resultados mostrados.

De qualquer maneira, os resultados demonstram uma expressão diferencial entre os alelos de XPC. Embora os resultados obtidos sejam oriundos de linhagens de melanoma e nos sirvam apenas como modelos, não se pode estender com certeza os resultados para melanócitos, os quais dão origem aos melanomas. É possível que 
melanócitos também apresentem expressão diferencial alelo-específica de XPC em indivíduos heterozigotos. Neste caso, a avaliação alelo-específica de XPC em linhagens de melanócitos, ou mesmo, em amostras oriundas de biópsias de pele, apresentaria uma melhor avaliação desta hipótese.

Expressão alélica diferencial é um evento comum que tem sido descrita para genes humanos, sendo a metodologia de análise inicialmente usada foi utilizando plataformas com sondas de oligonucleotídeos alelo-específica (Lo et al., 2003). Neste estudo, os autores identificaram expressão diferencial em 326/602 genes humanos, em tecidos do rim e fígado. Depois, utilizando a metodologia TaqMan ${ }^{\circledR}$, esta técnica foi aplicada para a identificação de expressão alélica diferencial em genes $B R C A 1$ e $B R C A 2$ em pacientes com câncer de mama e ovário (Chen et al., 2008; Shen et al., 2010). Recentemente, este ensaio tem sido utilizado como experimento adicional na caracterização funcional de SNPs (Lubbe et al., 2012; Pillay et al., 2012). Apesar de ser uma técnica amplamente divulgada, existe amplificação inespecífica de sonda e isso, gera a necessidade de aplicar vários cálculos de normalização de sinal para confiabilidade dos resultados.

Mesmo que os resultados para a expressão alelo-especifica tenham sugerido maior expressão do alelo Q, o qual estaria envolvido com o risco de desenvolvimento de melanomas (Gonçalves et al., 2011), os resultados não esclarecem o papel deste alelo no desenvolvimento desta neoplasia. Para isto, o ensaio funcional seria adequado para se obter maiores informações e dados. Este polimorfismo está localizado na região da proteína que interage com o fator TFIIH, o qual é responsável pelos passos posteriores ao reconhecimento da lesão no NER, onde tal mudança de aminoácidos poderia 
modificar a interação dessas duas moléculas culminando em consequências para a atividade de reparo.

Estudo funcional realizado com a transfecção das duas variantes em células deficientes em XPC, não revelou diferenças entre a atividade de reparo frente a lesões UV dos dois alelos (Khan et al. 2000). Outros estudos funcionais, porém baseados em ensaios utilizando-se linfócitos, seja através de ensaios de cometa (Pavanello et al. 2005; Cornetta et al. 2006) ou através da medida de capacidade de reparo (Qiao et al. 2002) sugeriram menor atividade do alelo Gln frente a diferentes agente lesivos, como por exemplo UV. Por outro lado, há também estudos que não demonstram tal associação (Vodicka et al. 2004; Naccarati et al. 2006), o que nos leva a supor que diferentes condições in vitro podem estar relacionadas a estas diferenças nos resultados, e além disso, a variação genética existente entre a população analisada nestes estudos tem considerável importância na interpretação dos resultados. De qualquer modo, os estudos epidemiológicos têm demonstrado associação deste polimorfismo com alguns tipos de câncer como mama (Zhang et al. 2005), bexiga (Sanyal et al. 2004), melanoma (Blankenburg et al. 2005) enquanto para carcinoma basocelular (Festa et al. 2005), adenoma de esôfago (Ye et al. 2006) os resultados não indicaram nenhuma associação. Esta tendência pode indicar uma tecido-especificidade onde uma menor atividade de reparo do alelo Q seria atribuída a determinado tipo celular.

Se realmente o alelo $Q$ tiver menor capacidade de reparo em comparação ao alelo K (como sugerem alguns estudos acima citados), essa maior expressão deste alelo também pode contribuir para a aquisição de mutações carcinogênicas por UV, uma vez que este alelo mais expresso e de menor atividade aumente a probabilidade de ocorrência destes fenômenos. Se ocorrer essa diferença de expressão em melanócitos 
em indivíduos heterozigotos, essa predominância de expressão aliada a menor capacidade de reparo, contribuiria na aquisição de mutações carcinogênicas, se ocorrer em células já transformadas pode contribuir para a diversidade de mutações que favorecem o desenvolvimento tumoral. Vale lembrar que indivíduos heterozigotos para os polimorfismos de XPC já demonstraram maior risco de desenvolvimento de melanoma (Gonçalves et al., 2011). Já os indivíduos homozigotos para o polimorfismo, um possível desbalanço de expressão alélica não teria o mesmo efeito, porém a expressão de isoformas com capacidade de reparo inferior ao comparado aos alelos selvagens, já contribuiria também em uma possível atividade de reparo menor, facilitando ao final o desenvolvimento de melanomas. Embora essas questões sejam apenas sugestões e hipóteses, novamente o teste funcional dos alelos, sob o controle de expressão mais próximo da fisiologia celular real, como por exemplo, em expressar os alelos K e Q sob o controle de promotor responsivo a p53, seria a melhor maneira de se avaliar tais questões levantadas.

5.4 Função dos agentes modificadores da via GGR-NER na resposta à UVB, na atividade de XPC e na resposta ao tratamento com o quimioterápico cisplatina em melanomas: Visão geral e integrativa de processos

As vias de reparo de DNA bem como a vias moduladoras da atividade do reparo de DNA têm sido exploradas quanto a sua participação em processos de carcinogênese, progressão tumoral e também quanto a resistência a quimioterápicos. A relação de vias de reparo com processos carcinogênicos já é conhecido há algum tempo, visto a relação existente entre mutações herdáveis em genes de reparo e maior susceptibilidade a 
determinados tipos tumorais, como por exemplo, mutações em BRCA e câncer de mama, mutações em MSH2 e câncer de colorectal, mutações em genes da via NER e câncer de pele. Enquanto para estes casos onde mutações herdáveis possuem alta penetrância, para o desenvolvimento de tumores esporádicos, o envolvimento destas vias sempre foi objeto de estudo.

Em melanomas, este conhecimento sobre a relação de vias de reparo e desenvolvimento/progressão e resistência tem ganhado grande impulso nos últimos anos. O sequenciamento completo do genoma de melanomas, mostrando a grande quantidade de lesões típicas de UV (principalmente em regiões não transcritas), evidenciou e fundamentou o conceito de que falhas no reparo destas lesões são cruciais para o processo de transformação maligna desta neoplasia. Em especial a participação de XPC, que atua na sub-via GGR-NER no reparo de lesões em regiões não transcritas do genoma. Como o papel de XPC já é conhecido na gênese de tumores cutâneos, incluindo melanomas, na síndrome do Xeroderma Pigmentosum, a modulação da sua atividade, bem como, a modulação da via de reparo NER mostrou-se de interesse quanto a um maior entendimento dos processos carcinogênicos envolvidos.

Neste sentido, explorou-se como XPC e consequentemente a via de reparo NER podia ser modulada inicialmente pela participação de p53. Os resultados demonstraram que p53 participa de maneira importante na modulação da via NER por promover a expressão de proteínas desta via como XPC, XPV e DDB-2, e consequentemente modular a sensibilidade. De fato, o papel de p53 na atividade transcricional de XPC parece operar em sua região promotora (Hastak et al., 2012). A questão aqui em torno do eixo p53-NER/XPC reside na hipótese aqui levantada de que a perda de p53 por mutações deletérias em melanócitos é prejudicial ao desenvolvimento de melanomas 
por aumentar a sensibilidade às lesões UV, potencialmente letais a célula. A favor desta hipótese temos os dados mutacionais em p53 em amostras de melanomas, os quais são bem abaixo dos observados para outros tipos tumorais, como discutido acima.

Se a perda da atividade de p53 não parece ser um evento inicial no desenvolvimento de melanomas, que fatores poderiam então modular sua atividade, como também a atividade de NER/XPC de maneira a permitir o acumulo de mutações carcinogênicas que favoreceriam o processo de transformação maligna? Neste sentido, procurou-se analisar agora a modulação da atividade de reparo exercida por XPC em relação a sua interação com seu principal partner, no caso hHR23B. Os resultados apresentados sugerem que esta modulação exercida por hHR23B em XPC pode ser um mecanismo que facilite o acúmulo das mutações carcinogênicas. $\mathrm{O}$ ponto inicial desta discussão está baseada nos resultados obtidos na análise de imuno-histoquimica que mostrou que a expressão de hHR23B apresentou um padrão heterogêneo em lesões névicas. Ao considerarmos células ou mesmo clones celulares que apresentam baixa expressão de hHR23B pode-se traçar um cenário pró-carcinogênico com base nos resultados que as linhagens de melanomas com baixa expressão de hHR23B demonstram. Para tais linhagens, a baixa expressão de hHR23B modifica a estabilidade e consequentemente a expressão de XPC, culminando com menor atividade de reparo de DNA frente a lesões UVB.

Não apenas a estabilidade de XPC e o reparo de DNA que a baixa expressão de hHR23B acarreta, esta baixa expressão também parece alterar a funcionalidade de p53, uma vez que estudos têm mostrado não só a interação entre ambas proteínas como também a função de hHR23B em auxiliar a atividade transcricional de p53 (Kaur et al., 2007). Esta modulação que hHR23B exerce em p53 parece alterar sua afinidade a se 
ligar a regiões promotoras, como por exemplo a região promotora de p21, e como consequência parece alterar a atividade transcricional de p53, incluindo na transcrição de proteínas relacionadas a morte celular, culminando com diminuição da taxa de morte celular após danos genotóxicos, seja por UV ou quimioterápicos (Kaur et al., 2007). Este cenário sugere uma importante função de hHR23B, pois sua diminuição de expressão poderia alterar a cinética de reparo e de morte celular também em exposições à UV, levando ao acúmulo de mutações carcinogênicas. Tais sugestões sobre o papel de hHR23B no entanto está baseado mais nos achados da literatura e nos resultados para Skmel-37. A análise das funções de hHR23B quanto a seu papel na carcinogênese de melanomas será melhor fundamentada usando-se demais modelos e linhagens, sendo inclusive interessante o uso de linhagens de melanócitos. Os resultados de expressão de hHR23B em tecidos também demonstrou que a expressão da proteína parece ter aumento já nas amostras transformadas, sugerindo que para a progressão da neoplasia a baixa expressão não é mais um fator importante. No entanto sua alta expressão pode ter algum significado. Primeiramente que seu aumento de expressão pode estar relacionada a manutenção do genoma tumoral, conforme padrão sugerido por Kauffmann e colaboradores (Kauffman et al., 2008). Em segundo lugar a alta expressão citoplasmática de hHR23B também sugere uma outra função da proteína.

Enquanto a modulação de XPC pôde ser vista em nível transcricional mediante p53 e em nível de interação com o principal partner hHR23B, um terceiro nível de modulação poderia através por elementos genéticos em situação cis, sendo o melhor exemplo a existência de variações genéticas. A ideia da análise de impactos de polimorfismos genéticos em genes ganhou importante força na ultima década com os primeiros estudos epidemiológicos-moleculares que começam a descrever associações 
entre variações genéticas e desenvolvimento de doenças, neste caso em específico o desenvolvimento de neoplasias. No caso específico de XPC, os resultados originados do artigo de Gonçalves e colaboradores (Gonçalves et al., 2011) mostraram que algumas variações genéticas poderiam de fato estar relacionadas com melanoma. Os polimorfismos existentes e analisados sugeriam um possível papel referente à estabilidade do RNA mensageiro, no caso uma modulação a nível transcricional, e outra referente à proteína, neste caso uma modulação a nível proteíco. No corpo de resultados apresentados, conseguiu-se apenas analisar a possível relação referente à estabilidade de RNA através de analise de expressão alelo específico. Embora a técnica tenha se mostrado factível, os resultados em geral se mostraram controversos, pois o alelo mais expresso foi o que se mostrou de risco no estudo epidemiológico em algumas linhagens analisadas.

Quanto ao polimorfismo que sugeria possibilidade de uma modulação a nível proteica, uma vez que altera aminoácidos, não pode ser analisada neste corpo de resultados. Embora os resultados não tenham evidenciado o papel dos polimorfismos na modulação de XPC, não se pode excluir de fato tal participação, uma vez que não se verificou o papel do polimorfismo K939Q, como discutido acima, e também uma possível modulação em nível transcricional ainda é possível, visto que o mais adequado seria uma análise alelo específica seja em melanócitos ou nevus, se possível in situ, ou mesmo em linhagens. De qualquer maneira, nesta tese também se analisou a possível modulação de XPC abordando o papel de variantes genéticas.

Todo o cenário desenhado pelos resultados indicou que a modulação do sistema de reparo NER pode ter função importante no processo carcinogênese e na progressão. O passo final abordado seria de verificar como os melanomas poderiam se comportar 
frente a agentes quimioterápicos, uma vez que o sistema de reparo bem como as vias moduladoras podem se encontrar alterados, conforme os resultados sugerem. Neste sentido, notou-se que os fatores que levam a inativação funcional de p53 podem contribuir em um primeiro momento para a progressão da neoplasia (Yu et al., 2009) quanto para a posterior resistência à quimioterápicos. Os resultados indicaram que p53 possui efeito importante nesta resistência e que o uso de Nutlin-3 contribui para a aquisição de sensibilidade. HHR23B, que pode modular tanto XPC quanto p53 também parece estar relacionado à sensibilidade a quimioterápicos, uma vez que sua inibição pode aumentar ou diminuir tal sensibilidade, dependente do tipo do quimioterápico, denotando, portanto um papel diversificado quanto a sua função celular. Tanto os fatores moduladores de XPC quanto sua própria atividade no reparo de lesões parecem estar relacionados à sensibilidade.

Por fim, o que os resultados desta tese demonstram o importante papel das vias de reparo de DNA, em especial a via NER, bem como fatores que modulem sua atividade como fatores importantes na biologia de melanomas. O foco mais importante nestas relações foi o papel de XPC e seus moduladores, tanto em nível transcricional, genético e proteíco, onde os resultados sugerem a participação de XPC em importantes processos dentro desta intrigante questão relacionada ao desenvolvimento de tumores, no caso específico de melanomas.

Cabe ao final uma pequena observação quanto aos modelos celulares utilizados, em especial à linhagem Skmel-37. Resultados observados por colaborador externo durante a parte final do trabalho, utilizando-se vetores para silenciamento estável de p53, demonstrou que nesta linhagem, o silenciamento estável leva a diminuição do crescimento e sobrevivência da linhagem (anexo F). Estes resultados foram de encontro 
aos resultados obtidos para linhagem sabidamente selvagens para p53, onde as mesmas ganharam em crescimento e sobrevivência após silenciamento. Tal resultado, embora não confirmado, sugere que em Skmel-37 possa haver alterações seja no próprio gene de p53 ou na via, que ofereçam uma atividade de ganho de função (Freed-Pastor \& Prives, 2012). De fato, tais alterações, caso estejam presentes, não levam a perda funcional, pois os resultados sugerem atividade transcricional da proteína. Contudo, tais alterações podem alterar ou mascarar resultados quando comparados com situações de atividade normal de p53. Pode-se reforçar tal linha de argumentação baseado nos fortes dados existentes indicando uma complexa interação entre XPC-hHR23B-p53 (Krzeszinski et al., 2014), onde estas proteínas podem interagir entre si de maneira dependente ou ate independente da terceira, tornado os processos relativos a estas interações susceptíveis a alterações que interfiram na completa funcionalidade da interação e funcionalidade dos indivíduos. Confirmação dos resultados e melhor exploração da relação XPC-hHR23B-p53 em outras linhagens de melanomas ou até melanócitos se torna um importante objetivo para a questão envolvendo esta interação.

O corpo de resultados aqui apresentado nesta tese denotam e destacam a importância que a modulação de vias de reparo de DNA e mais precisamente de componentes desta via atuam de maneira importante em diferentes passos da biologia de melanomas, desde fases pré-carcinogênicas até fases de evolução e progressão avançada da doença como no caso de resistência a quimioterápicos. $\mathrm{O}$ objeto de estudo aqui contemplado pode e deve ser base para futuras investigações que elucidem cada vez mais o papel destas vias e modulações. 


\section{CONCLUSÕES}

Ao final do trabalho desenvolvido durante a realização desta tese, é possível chegar a algumas conclusões relativas ao papel do eixo p53-hHR23B-XPC em melanomas. Estas conclusões são:

- Alterações em p53 apresentam como consequências diferentes respostas após exposição à UVB ou Cisplatina. Enquanto em células p53 mutantes a exposição à UVB culmina com maior sensibilidade devido a menor capacidade de reparo de lesões causada por menor expressão de genes de reparo, após exposição à cisplatina, as mesmas células podem apresentar resistência, embora possam apresentar a mesma baixa expressão de genes de reparo;

- Espécies reativas de oxigênio produzidas após UVB podem influenciar as respostas à morte celular. $\mathrm{O}$ uso de substâncias envolvidas em neutralizar espécies reativas como Catalase e Tempol aumentaram a sensibilidade à UVB.

- Atividades de recuperação da via de p53 podem aumentar a sensibilidade à cisplatina em melanomas. O uso de Nutlin-3 e reativação de p53 aumentou a sensibilidade dos melanomas à cisplatina, demonstrando que o uso de pequenas moléculas ativadoras da via podem servir como terapia combinada com quimioterápicos.

- Expressão de hHR23B é heterogênea em amostras de nevus e pode contribuir para o processo carcinogênico de melanomas por modular a ação de reparo via XPC. As análises a partir do TMA indicaram grande heterogeneidade de expressão de hHR23B nas amostras de nevus e os resultados utilizando-se linhagens de melanomas demonstraram que na baixa expressão de hHR23B, XPC apresenta menor estabilidade e acúmulo após UVB o que leva a menor eficiência no reparo de DNA. 
- Complexo hHR23B e XPC atua de maneira diferenciada em diferentes tipos de danos no DNA. Resultados para uso de diferentes agentes que causam danos no DNA demonstrou que hHR23B e/ou XPC estão relacionados ao reparo de lesões causadas por cisplatina e doxorrubicina, enquanto para outros agentes quimioterápicos como 5', Fluoracil e Etoposídeo o complexo parece não estar relacionado. Além disso, para agentes como etoposídeo, tunicamicina e até UVB, a baixa expressão de hHR23B leva a menor taxa de morte.

- Polimorfismos de XPC não estão relacionados diretamente com diferença de expressão alelo-específica. Resultados demonstraram que os polimorfismos de XPC não alteraram a expressão de XPC, onde amostras heterozigotas para K939Q não apresentaram diferenças na expressão alelo-específica, o que também não refuta a hipótese de que essas variações polimórficas exerçam função na proteína. 


\section{ANEXOS}

ANEXO A

Tabela referente a dosagem de melanina nas linhagens Skmel-28 e Skmel-37

\begin{tabular}{|l|c|c|}
\hline & $400 \mathbf{n m}$ & $\mathbf{4 7 0} \mathbf{n m}$ \\
\hline Skmel-188 (ref) & 0,162 & 0,117 \\
\hline Skmel-28 & 0,078 & 0,09 \\
\hline Skmel-37 & 0,03 & 0,02 \\
\hline
\end{tabular}


ANEXO B

Fotomicrografias de marcação de foci de fosfo-H2AX após $120 \mathrm{~J} / \mathrm{m}^{2}$ de UVB em Skmel-28 e Skmel-37

Skmel-28

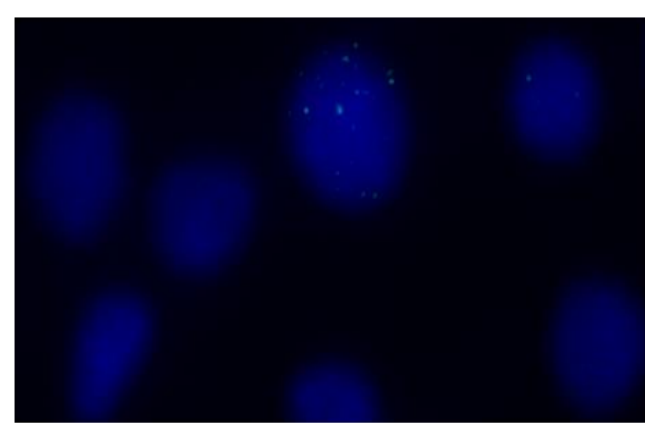

$24 \mathrm{~h}$

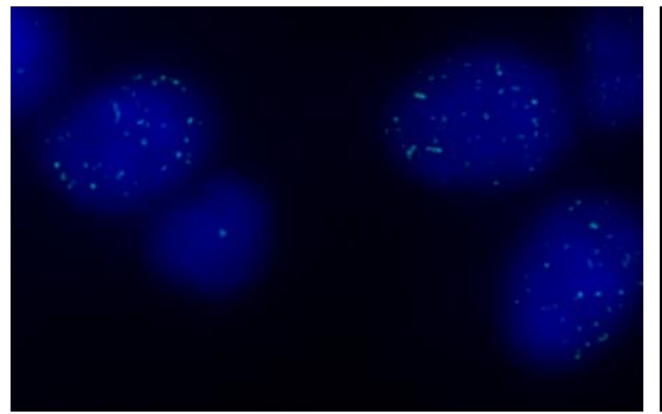

CTL

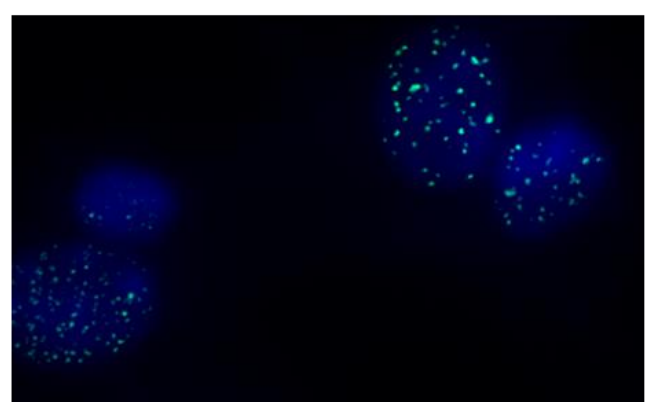

Skmel-37
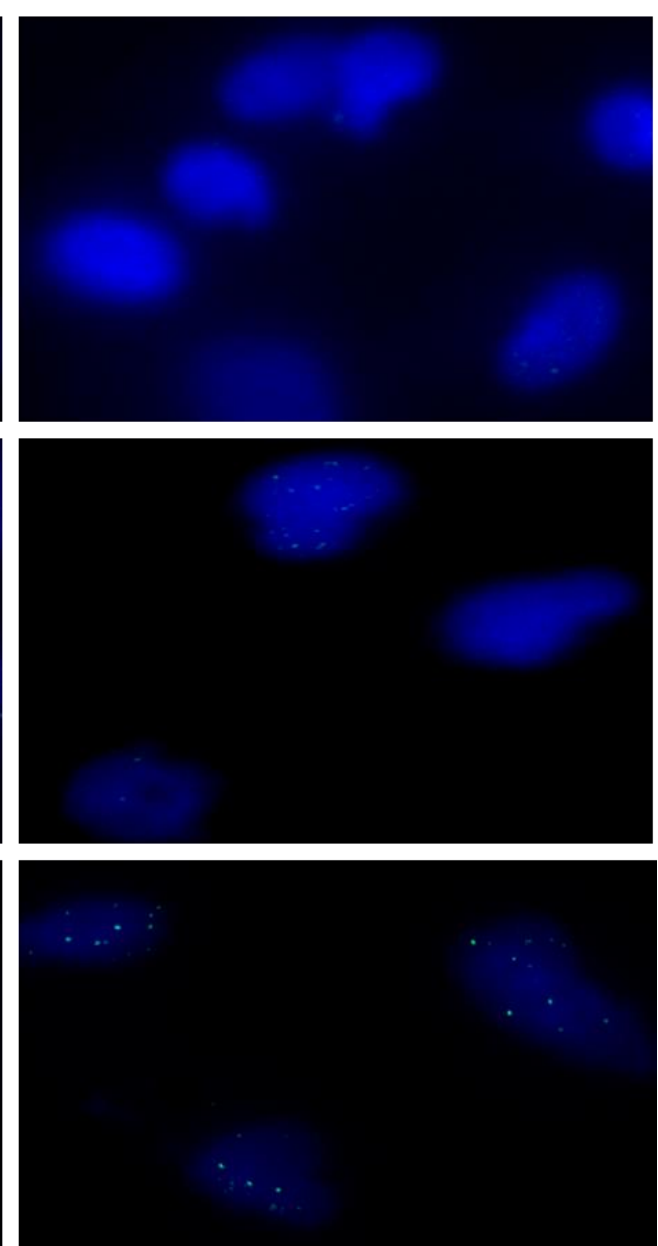


\section{ANEXO C}

Dot plots para a ativação de Caspase 3/7 em Skmel-28 e Skmel-37 nas situações controle, $24 \mathrm{~h}$ e $48 \mathrm{~h}$ após exposição à $120 \mathrm{~J} / \mathrm{m}^{2}$ de UVB.

Skmel-28
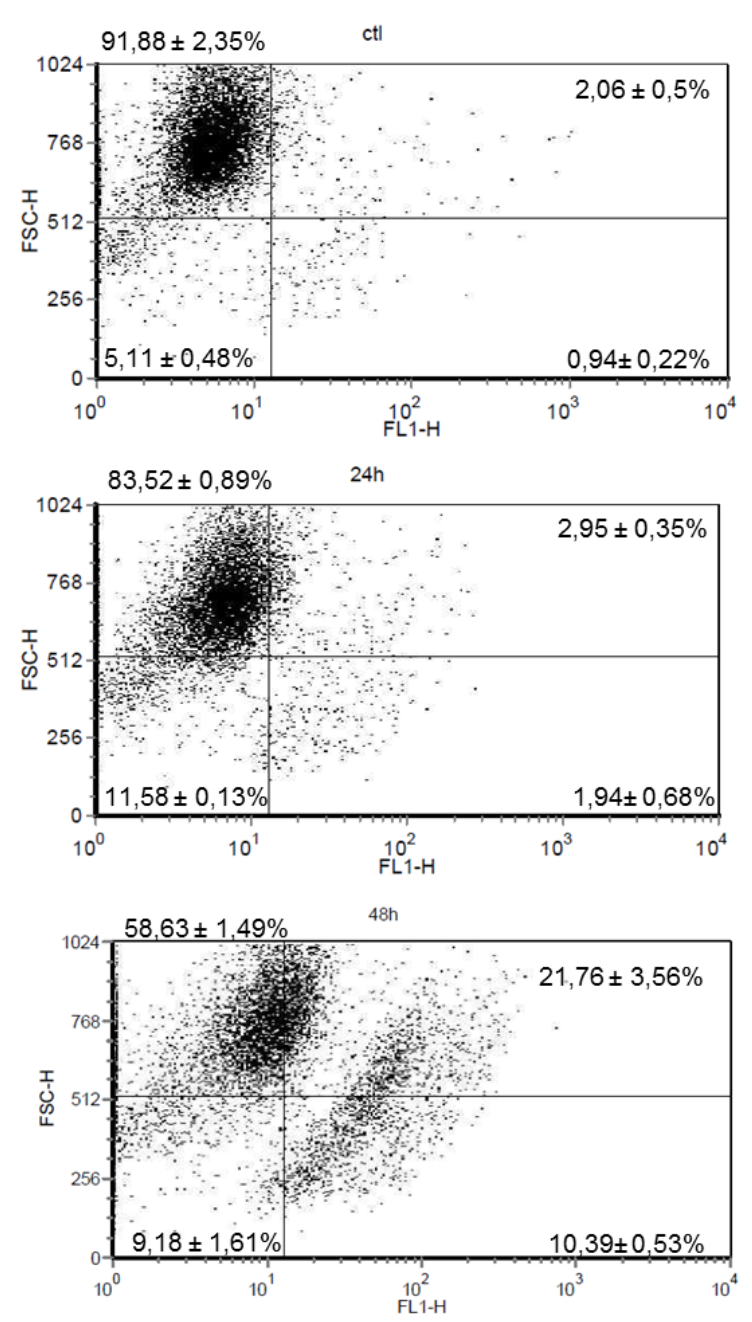

Skmel-37
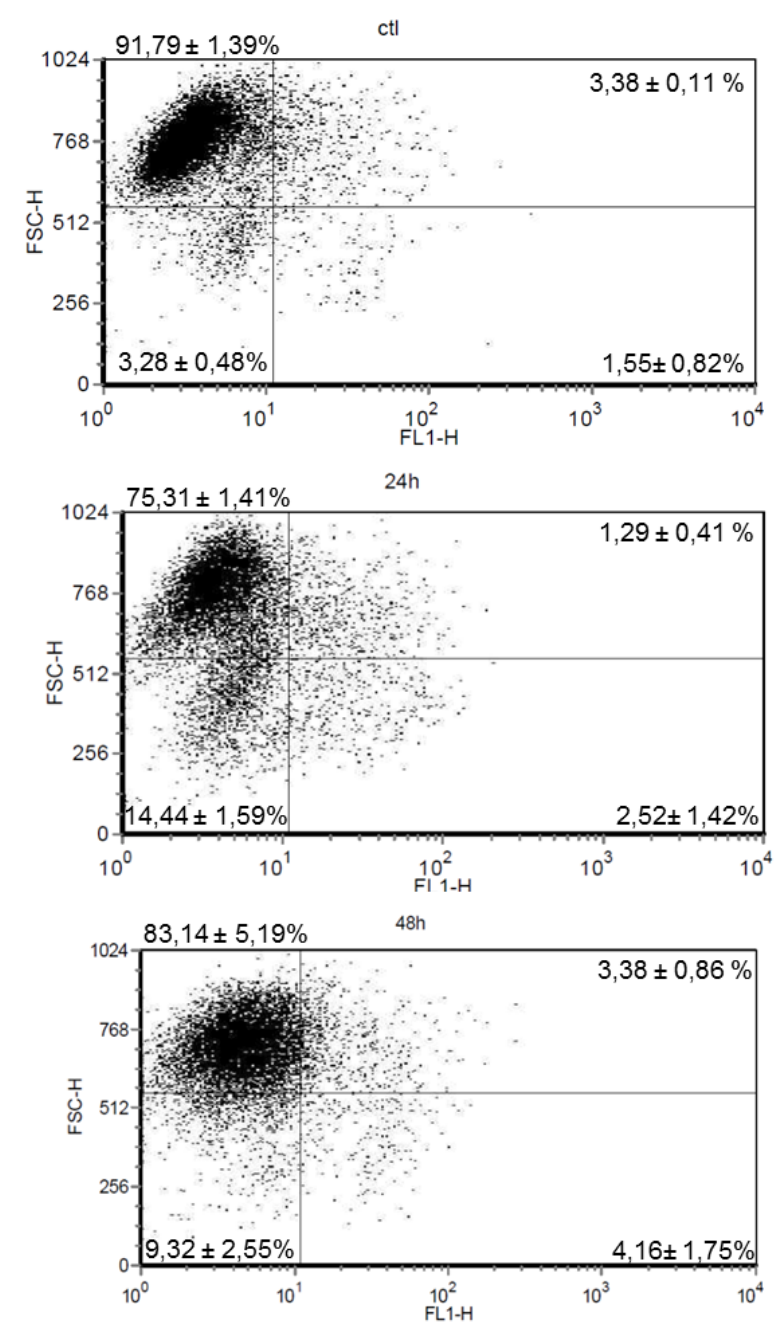

Os valores acima indicam média e desvio padrão de duplicatas. Resultado representativo de triplicatas independentes. 
ANEXO D

Efeito de Catalase (A) e Tempol (B) na produção de espécies reativas de oxigênio após UVB

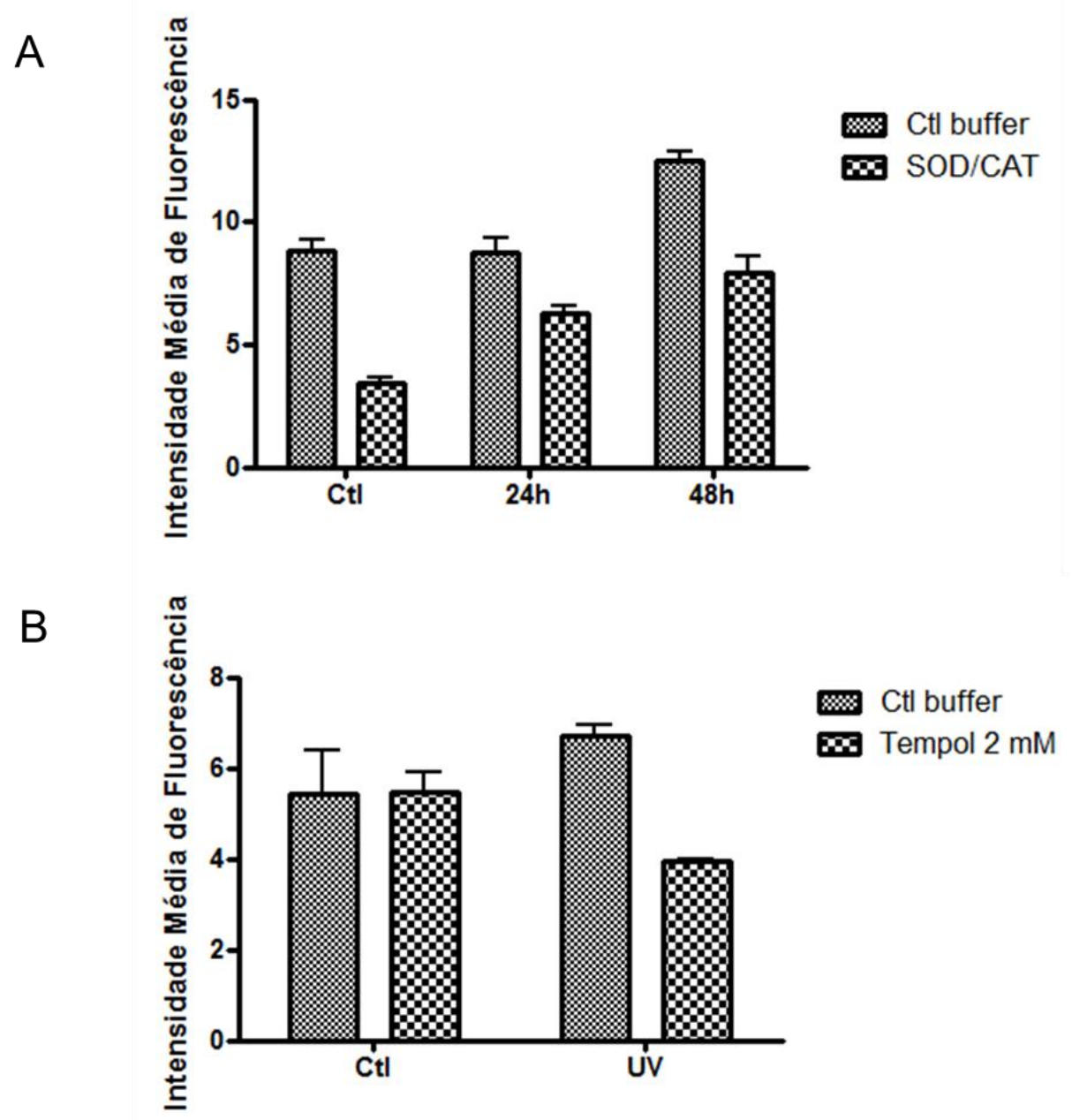

Os valores acima indicam média e desvio padrão de triplicatas. Resultado representativo de duplicatas independentes. 


\section{ANEXO E}

Dot plots para a ativação de Caspase 3/7 em Skmel-28 e Skmel-37 nas situações controle, $24 \mathrm{~h}$ e $48 \mathrm{~h}$ após exposição à $12.5 \mu \mathrm{M}$ de cisplatina.
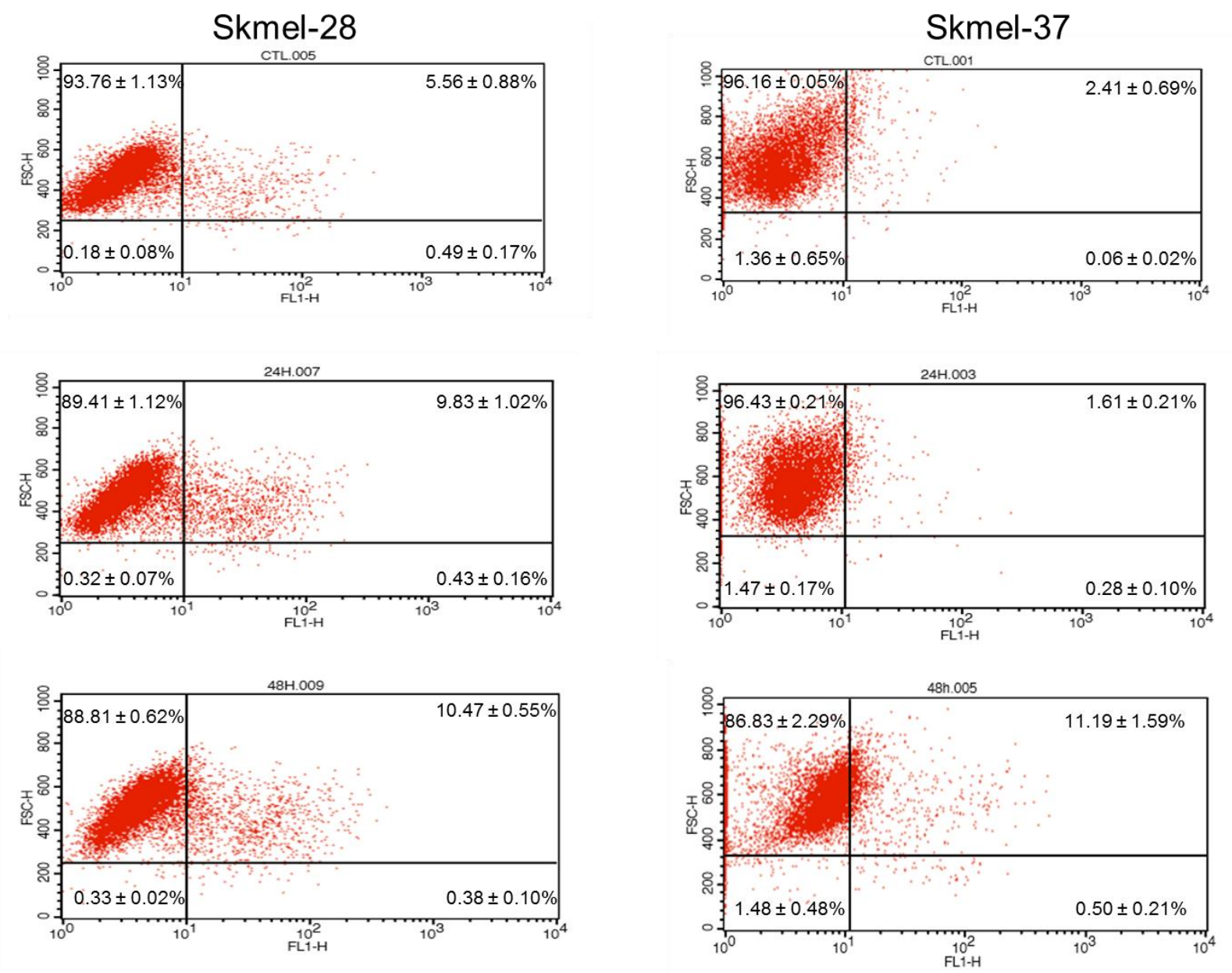

Os valores acima indicam média e desvio padrão de duplicatas. Resultado representativo de triplicatas independentes. 


\section{BIBLIOGRAFIA}

Adimoolam S, Ford JM. p53 and DNA damage-inducible expression of the xeroderma pigmentosum group C gene. Proc. Natl. Acad. Sci. USA. 2002, 99, 12985-12990.

Albert PR. What is a functional genetic polymorphism? Defining classes of functionality. J Psychiatry Neurosci. 2011;36(6):363-5.

Alberts, B. Johnson, A. Lewis, J. Raff, M. Roberts, K. Walter, P. Molecular Biology of the Cell. 5 ed. New York: Garland science, Taylor \& Francis Group, 2008.

Ali AY, Farrand L, Kim JY, Byun S, Suh JY, Lee HJ, Tsang BK. Molecular determinants of ovarian cancer chemoresistance: new insights into an old conundrum. Ann N Y Acad Sci. 2012;1271:58-67.

Altaha R, Liang X, Yu JJ, Reed E. Excision repair cross complementing-group 1: gene expression and platinum resistance. Int J Mol Med. 2004;14(6):959-70.

Altilia S, Santoro A, Malagoli D, Lanzarini C, Ballesteros Álvarez JA, Galazzo G, Porter DC, Crocco P, Rose G, Passarino G, Roninson IB, Franceschi C, Salvioli S. TP53 codon 72 polymorphism affects accumulation of mtDNA damage in human cells. Aging (Albany NY). 2012;4(1):28-39.

Ambrosini G, Sambol EB, Carvajal D, Vassilev LT, Singer S, Schwartz GK. Mouse double minute antagonist Nutlin-3a enhances chemotherapy-induced apoptosis in cancer cells with mutant p53 by activating E2F1. Oncogene. 2007; 26:3473-81.

Arnould S, Hennebelle I, Canal P, Bugat R, Guichard S. Cellular determinants of oxaliplatin sensitivity in colon cancer cell lines, Eur. J. Cancer. 2003; 39:112-119.

Arya AK, El-Fert A, Devling T, Eccles RM, Aslam MA, Rubbi CP, Vlatkovic N, Fenwick J, Lloyd BH, Sibson DR, Jones TM, Boyd MT. Nutlin-3, the small-molecule inhibitor of MDM2, promotes senescence and radiosensitises laryngeal carcinoma cells harbouring wild-type p53. Br J Cancer. 2010; 103:186-95.

Assunção Guimarães C, Linden R. Programmed cell deaths. Apoptosis and alternative deathstyles. Eur J Biochem. 2004;271(9):1638-50.

Babak T, Garrett-Engele P, Armour CD et al. Genetic validation of wholetranscriptome sequencing for mapping expression affected by cis-regulatory variation. BMC Genomics. 2010;11: 473.

Bäckvall H, Strömberg S, Gustafsson A, Asplund A, Sivertsson A, Lundeberg J, Ponten F. Mutation spectra of epidermal p53 clones adjacent to basal cell carcinoma and squamous cell carcinoma. Exp Dermatol. 2004;13(10):643-50.

Balint E, Vousden KH. Activation and activities of the p53 tumour suppressor protein. Br J Cancer. 2001;85:1813-1823. 
Barckhausen C, Roos WP, Naumann SC, Kaina B. Malignant melanoma cells acquire resistance to DNA interstrand cross-linking chemotherapeutics by p53-triggered upregulation of DDB2/XPC-mediated DNA repair. Oncogene. 2014;33(15):1964-74.

Batista LF, Roos WP, Kaina B, Menck CF. p53 mutant human glioma cells are sensitive to UV-C-induced apoptosis due to impaired cyclobutane pyrimidine dimer removal. Mol Cancer Res. 2009;7(2):237-46.

Bauman JE, Austin MC, Schmidt R, Kurland BF, Vaezi A, Hayes DN, Mendez E, Parvathaneni U, Chai X, Sampath S, Martins RG. ERCC1 is a prognostic biomarker in locally advanced head and neck cancer: results from a randomised, phase II trial. $\mathrm{Br} J$ Cancer. 2013;109(8):2096-105.

Bellmunt J, Pons F, Orsola A. Molecular determinants of response to cisplatin-based neoadjuvant chemotherapy. Curr Opin Urol. 2013;23(5):466-71.

Benjamin CL, Ullrich SE, Kripke ML, Ananthaswamy HN. p53 tumor suppressor gene: a critical molecular target for UV induction and prevention of skin cancer. Photochem Photobiol. 2008;84(1):55-62.

Bennett DC, Cooper PJ, Hart IR. A line of non-tumorigenic mouse melanocytes, syngeneic with the B16 melanoma and requiring a tumour promoter for growth. Int $\mathrm{J}$ Cancer. 1987;39(3):414-8.

Bergink S, Toussaint W, Luijsterburg MS, Dinant C, Alekseev S, Hoeijmakers JH, Dantuma NP, Houtsmuller AB, Vermeulen W. Recognition of DNA damage by XPC coincides with disruption of the XPC-RAD23 complex. J Cell Biol. 2012;196(6):681-8.

Bharthuar A, Saif Ur Rehman S, Black JD, Levea C, Malhotra U, Mashtare TL, Iyer R. Breast cancer resistance protein (BCRP) and excision repair cross complement-1 (ERCC1) expression in esophageal cancers and response to cisplatin and irinotecan based chemotherapy. J Gastrointest Oncol. 2014;5(4):253-8.

Blankenburg S, Konig IR, Moessner R, et al. Assessment of 3 xeroderma pigmentosum group $\mathrm{C}$ gene polymorphisms and risk of cutaneous melanoma: a case-control study. Carcinogenesis. 2005; 26:1085-90.

Bowden NA, Ashton KA, Avery-Kiejda KA, Zhang XD, Hersey P, Scott RJ. Nucleotide excision repair gene expression after Cisplatin treatment in melanoma. Cancer Res. 2010, 70, 7918-7926.

Bowden NA. Nucleotide excision repair: Why is it not used to predict response to platinum-based chemotherapy? Cancer Lett. 2014;346(2):163-71.

Bradbury PA, Middleton, MR. DNA repair pathways in drug resistance in melanoma. Anti-Cancer Drugs. 2004, 15, 421-426. 
Bradford PT, Goldstein AM, Tamura D, Khan SG, Ueda T, Boyle J, Oh KS, Imoto K, Inui H, Moriwaki S, Emmert S, Pike KM, Raziuddin A, Plona TM, DiGiovanna JJ, Tucker MA, Kraemer KH. Cancer and neurologic degeneration in xeroderma pigmentosum: long term follow-up characterises the role of DNA repair. J Med Genet. 2011;48(3):168-76.

Brignone C, Bradley KE, Kisselev AF, Grossman SR. A post-ubiquitination role for MDM2 and hHR23A in the p53 degradation pathway. Oncogene. 2004;23(23):4121-9.

Budden T, Bowden NA. The Role of Altered Nucleotide Excision Repair and UVBInduced DNA Damage in Melanomagenesis. Int J Mol Sci. 2013;14:1132-51.

Carey TE, Lloyd KO, Takahashi T, Travassos LR, Old LJ. AU cell-surface antigen of human malignant melanoma: solubilization and partial characterization. Proc Natl Acad Sci U S A. 1979;76(6):2898-902.

Carvalho H, Garrido LM, Furlan RL, Padilla G, Agnoletto M, Guecheva T, Henriques JA, Saffi J, Menck CF. DNA damage induced by the anthracycline cosmomycin D in DNA repair-deficient cells. Cancer Chemother Pharmacol. 2010;65(5):989-94.

Cavallo F, Feldman DR, Barchi M. Revisiting DNA damage repair, p53-mediated apoptosis and cisplatin sensitivity in germ cell tumors. Int J Dev Biol. 2013;57(24):273-80.

Chen X, Weaver J, Bove B et al. Allelic imbalance in BRCA1 and BRCA2 gene expression is associated with an Increased breast cancer risk. Hum Mol Genet. 2008; 17:1336-1348,

Chorley BN, Wang X, Campbell MR, et al. Discovery and verification of functional single nucleotide polymorphisms in regulatory genomic regions: current and developing technologies. Mutat Res. 2008;659:147-57.

Cigliano L, Manz RA, Daniel PT, Bommert K, Vassilev LT, Bargou RC. Nongenotoxic activation of the p53 pathway as a therapeutic strategy for multiple myeloma. Blood. 2005; 106:3609-17.

Clement FC, Camenisch U, Fei J, Kaczmarek N, Mathieu N, Naegeli H. Dynamic twostage mechanism of versatile DNA damage recognition by xeroderma pigmentosum group C protein. Mutat Res. 2010;685:21-8.

Coll-Mulet L, Iglesias-Serret D, Santidrian AF, Cosialls AM, de Frias M, Castano E, Campas C, Barragan M, de Sevilla AF, Domingo A, Vassilev LT, Pons G, Gil J. MDM2 antagonists activate p53 and synergize with genotoxic drugs in B-cell chronic lymphocytic leukemia cells. Blood. 2006; 107:4109-14. 
Cornetta T, Festa F, Testa A, Cozzi R. DNA damage repair and genetic polymorphisms: assessment of individual sensitivity and repair capacity. Int J Radiat Oncol Biol Phys. 2006; 66:537-45.

Costa RM, Chigancas V, Galhardo R da S, Carvalho H, Menck CF. The eukaryotic nucleotide excision repair pathway. Biochimie. 2003;85:1083-99.

Curtin JA, Fridlyand J, Kageshita $\mathrm{T}$ et al. Distinct sets of genetic alterations in melanoma. N Engl J Med . 2005;353: 2135-2147.

Dantuma NP, Heinen C, Hoogstraten D. The ubiquitin receptor Rad23: at the crossroads of nucleotide excision repair and proteasomal degradation. DNA Repair (Amst). 2009;8:449-60.

de Snoo FA, Hayward NK. Cutaneous melanoma susceptibility and progression genes. Cancer Lett .2005;230(2):153-86.

Deaton AM, Bird A. CpG islands and the regulation of transcription. Genes Dev. 2011;25(10):1010-22.

D'Errico M, Parlanti E, Teson M, de Jesus BM, Degan P, Calcagnile A, Jaruga P, Bjørås M, Crescenzi M, Pedrini AM, Egly JM, Zambruno G, Stefanini M, Dizdaroglu M, Dogliotti E. New functions of XPC in the protection of human skin cells from oxidative damage. EMBO J. 2006;25(18):4305-15.

Despommier D, Chen SX. Medical ecology. Dísponível em: <URL:http:// www.medicalecology.org>, 2004. [2007 jul 01].

DiGiovanna JJ, Kraemer KH. Shining a light on xeroderma pigmentosum. $J$ Invest Dermatol. 2012;132(3 Pt 2):785-96.

Doss S, Schadt EE, Drake TA et al. Cis-acting expression quantitative trait loci in mice. Genome Res. 2005;15:681-691.

Enoiu M, Jiricny J, Schärer OD. Repair of cisplatin-induced DNA interstrand crosslinks by a replication-independent pathway involving transcription-coupled repair and translesion synthesis. Nucleic Acids Res. 2012;40(18):8953-64.

Festa F, Kumar R, Sanyal S, et al. Basal cell carcinoma and variants in genes coding for immune response, DNA repair, folate and iron metabolism. Mutat Res. 2005; 574:10511 .

Fidler IJ. Biological behavior of malignant melanoma cells correlated to their survival in vivo. Cancer Res. 1975;35(1):218-24.

Fitch M.E., Nakajima S., Yasui A., Ford J.M. In vivo recruitment of XPC to UVinduced cyclobutane pyrimidine dimers by the DDB2 gene product. J. Biol. Chem. 
2003;278:46906-46910.

Fogh J, Wright WC, Loveless JD. Absence of HeLa cell contamination in 169 cell lines derived from human tumors. J Natl Cancer Inst. 1977;58(2):209-14.

Ford JM, Hanawalt PC. Expression of wild-type p53 is required for efficient global genomic nucleotide excision repair in UV-irradiated human fibroblasts. J. Biol. Chem. 1997, 272, 28073-28080.

Francisco G, Cirilo PDR, Gonçalves FT, Tortelli Junior TC, Chammas R Melanoma Genetics: From Susceptibility to Progression. In: Duc H, editor. Melanoma - From Early Detection to Treatment. InTech, DOI: 10.5772/54143. 2013

Francisco G, Menezes PR, Eluf-Neto J, Chammas R. XPC polymorphisms play a role in tissue-specific carcinogenesis: a meta-analysis. Eur J Hum Genet. 2008;16(6):724-34.

Freed-Pastor WA, Prives C. Mutant p53: one name, many proteins. Genes Dev. 2012;26(12):1268-86.

Friedberg EC. How nucleotide excision repair protects against cancer. Nat. Rev. Cancer. 2001, 1, 22-33.

Gaddameedhi S, Kemp MG, Reardon JT, Shields JM, Smith-Roe SL, Kaufmann WK, Sancar A. Similar nucleotide excision repair capacity in melanocytes and melanoma cells. Cancer Res. 2010, 70, 4922-4930.

Gillette TG, Yu S, Zhou Z, Waters R, Johnston SA, Reed SH. Distinct functions of the ubiquitin-proteasome pathway influence nucleotide excision repair. EMBO J. 2006;25:2529-38.

Golubovskaya VM, Cance WG. Targeting the p53 pathway. Surg Oncol Clin N Am. 2013;22(4):747-64

Gonçalves FT, Francisco G, de Souza SP, Luiz OC, Festa-Neto C, Sanches JA, Chammas R, Gattas GJ, Eluf-Neto J. European ancestry and polymorphisms in DNA repair genes modify the risk of melanoma: a case-control study in a high UV index region in Brazil. J Dermatol Sci. 2011;64(1):59-66.

Gough DR, Cotter TG. Hydrogen peroxide: a Jekyll and Hyde signalling molecule. Cell Death Dis. 2011;2:e213.

Hadj-Rabia S, Oriot D, Soufir N, Dufresne H, Bourrat E, Mallet S, Poulhalon N, Ezzedine E, Grandchamp B, Taïeb A, Catteau B, Sarasin A, Bodemer C. Unexpected extradermatological findings in 31 patients with xeroderma pigmentosum type $\mathrm{C}$. Br J Dermatol. 2013;168(5):1109-1113. 
Hanawalt PC. Subpathways of nucleotide excision repair and their regulation. Oncogene. 2002; 21:8949-56.

Hastak K, Adimoolam S, Trinklein ND, Myers RM, Ford JM. Identification of a Functional In Vivo p53 Response Element in the Coding Sequence of the Xeroderma Pigmentosum Group C Gene. Genes Cancer. 2012;3(2):131-40.

Henderson LM, Chappell JB. Dihydrorhodamine 123: a fluorescent probe for superoxide generation? Eur J Biochem. 1993;217(3):973-80.

Hock AK, Vousden KH. The role of ubiquitin modification in the regulation of p53. Biochim Biophys Acta. 2014;1843(1):137-49.

Hoogstraten D, Bergink S, Ng JM, Verbiest VH, Luijsterburg MS, Geverts B, Raams A, Dinant C, Hoeijmakers JH, Vermeulen W, Houtsmuller AB. Versatile DNA damage detection by the global genome nucleotide excision repair protein XPC. J Cell Sci. 2008;121:2850-9.

Horikawa-Miura M, Matsuda N, Yoshida M, Okumura Y, Mori T, Watanabe M. The greater lethality of UVB radiation to cultured human cells is associated with the specific activation of a DNA damage-independent signaling pathway. Radiat Res. 2007;167: $655-662$.

Hosoi J, Abe E, Suda T, Kuroki T. Regulation of melanin synthesis of B16 mouse melanoma cells by 1 alpha, 25-dihydroxyvitamin D3 and retinoic acid. Cancer Res. 1985;45(4):1474-8.

Houben R, Hesbacher S, Schmid CP, Kauczok CS, Flohr U, Haferkamp S, et al. Highlevel expression of wild-type p53 in melanoma cells is frequently associated with inactivity in p53 reporter gene assays. PLoS One 2011;6(7):e22096.

Hwang BJ, Ford JM, Hanawalt PC, Chu G. Expression of the p48 xeroderma pigmentosum gene is p53-dependent and is involved in global genomic repair. Proc. Natl. Acad. Sci. USA. 1999, 96, 424-428.

Jacobelli S, Soufir N, Lacapere JJ, Regnier S, Bourillon A, Grandchamp B, Hétet G, Pham D, Palangie A, Avril MF, Dupin N, Sarasin A, Gorin I. Xeroderma pigmentosum group $\mathrm{C}$ in a French Caucasian patient with multiple melanoma and unusual long-term survival. Br J Dermatol. 2008;159(4):968-73.

Jewell R, Conway C, Mitra A, Randerson-Moor J, Lobo S, Nsengimana J, et al. Patterns of expression of DNA repair genes and relapse from melanoma. Clin Cancer Res. 2010;16(21):5211-21. 
Ji Z, Njauw CN, Taylor M, Neel V, Flaherty KT, Tsao H. p53 rescue through HDM2 antagonism suppresses melanoma growth and potentiates MEK inhibition. $J$ Invest Dermatol. 2012;132(2):356-64.

Jiang Y, Ke C, Mieczkowski P A, Marszalek P E. Detecting ultraviolet damage in single DNA molecules by atomic force microscopy. Biophys J. 2007;93: 1758-1767.

Kao WH, Riker AI, Kushwaha DS, Ng K, Enkemann SA, Jove R, et al., Upregulation of Fanconi anemia DNA repair genes in melanoma compared with non-melanoma skin cancer. J Invest Dermatol. 2011;131(10):2139-42.

Kauffmann A, Rosselli F, Lazar V, Winnepenninckx V, Mansuet-Lupo A, Dessen P, et al. High expression of DNA repair pathways is associated with metastasis in melanoma patients. Oncogene. 2008;27(5):565-73.

Kaur M, Pop M, Shi D, Brignone C, Grossman SR. hHR23B is required for genotoxicspecific activation of p53 and apoptosis. Oncogene. 2007;26:1231-7.

Khan SG, Metter EJ, Tarone RE, et al. A new xeroderma pigmentosum group C poly(AT) insertion/deletion polymorphism. Carcinogenesis. 2000; 21:1821-5.

Khan SG, Muniz-Medina V, Shahlavi T, et al. The human XPC DNA repair gene: arrangement, splice site information content and influence of a single nucleotide polymorphism in a splice acceptor site on alternative splicing and function. Nucleic Acids Res. 2002; 30:3624-31.

Klein Douwel D, Boonen RA, Long DT, Szypowska AA, Räschle M, Walter JC, Knipscheer P. XPF-ERCC1 acts in Unhooking DNA interstrand crosslinks in cooperation with FANCD2 and FANCP/SLX4. Mol Cell. 2014;54(3):460-71.

Klekotka PA, Cornelius LA, Linette GP, eds. Malignant Melanoma and Non-melanoma Skin Cancer: Ramaswamy Govindan: 2007.

Kollipara R, Cooley LD, Horii KA, Hetherington ML, Leboit PE, Singh V, Zwick DL. Spitzoid melanoma in a child with Li-Fraumeni syndrome. Pediatr Dev Pathol. 2014;17(1):64-9.

Kolpashchikov DM, Khodyreva SN, Khlimankov DY, Wold MS, Favre A, Lavrik OI. Polarity of human replication protein A binding to DNA. Nucleic Acids Res. 2001; 29:373-9.

Komarov PG, Komarova EA, Kondratov RV, Christov-Tselkov K, Coon JS, Chernov MV, Gudkov AV. A chemical inhibitor of p53 that protects mice from the side effects of cancer therapy. Science. 1999;285(5434):1733-7.

Krauthammer M, Kong Y, Ha BH, Evans P, Bacchiocchi A, McCusker JP, Cheng E, Davis MJ, Goh G, Choi M, Ariyan S, Narayan D, Dutton-Regester K, Capatana A, Holman EC, Bosenberg M, Sznol M, Kluger HM, Brash DE, Stern DF, Materin MA, Lo 
RS, Mane S, Ma S, Kidd KK, Hayward NK, Lifton RP, Schlessinger J, Boggon TJ, Halaban R. Exome sequencing identifies recurrent somatic RAC1 mutations in melanoma. Nat Genet. 2012;44(9):1006-14.

Krzeszinski JY, Choe V, Shao J, Bao X, Cheng H, Luo S, Huo K, Rao H. XPC promotes MDM2-mediated degradation of the p53 tumor suppressor. Mol Biol Cell. 2014;25(2):213-21.

Kulms D, Zeise E, Pöppelmann B, Schwarz T. DNA damage, death receptor activation and reactive oxygen species contribute to ultraviolet radiation-induced apoptosis in an essential and independent way. Oncogene. 2002;21(38):5844-51.

Kunz C, Focke F, Saito Y, Schuermann D, Lettieri T, Selfridge J, Schär P. Base excision by thymine DNA glycosylase mediates DNA-directed cytotoxicity of 5fluorouracil. PLoS Biol. 2009;7(4):e91.

Lai TC, Chow KC, Fang HY, Cho HC, Chen CY, Lin TY, Chiang IP, Ho SP. Expression of xeroderma pigmentosum complementation group $\mathrm{C}$ protein predicts cisplatin resistance in lung adenocarcinoma patients. Oncol Rep. 2011;25(5):1243-51.

Lau LM, Nugent JK, Zhao X, Irwin MS. HDM2 antagonist Nutlin-3 disrupts p73HDM2 binding and enhances p73 function. Oncogene. 2008; 27:997-1003.

Lee DH, Pfeifer GP. Deamination of 5-methylcytosines within cyclobutane pyrimidine dimers is an important component of UVB mutagenesis. J Biol Chem. 2003;278: 10314-10321.

Lee YC, Cai Y, Mu H, Broyde S, Amin S, Chen X, Min JH, Geacintov NE. The relationships between XPC binding to conformationally diverse DNA adducts and their excision by the human NER system: Is there a correlation? DNA Repair (Amst). 2014;19:55-63.

Li C, Liu Z, Wang LE, et al. Polymorphisms in the DNA repair genes XPC, XPD, and $\mathrm{XPG}$ and risk of cutaneous melanoma: a case-control analysis. Cancer Epidemiol Biomarkers Prev. 2006; 15:2526-32.

Li W, Melton DW. Cisplatin regulates the MAPK kinase pathway to induce increased expression of DNA repair gene ERCC1 and increase melanoma chemoresistance. Oncogene. 2012, 31, 2412-2422. 117.

Lin WC, Chuang YC, Chang YS, Lai MD, Teng YN, Su IJ, Wang CC, Lee KH, Hung $\mathrm{JH}$. Endoplasmic reticulum stress stimulates p53 expression through NF- $\kappa \mathrm{B}$ activation. PLoS One. 2012;7(7):e39120.

Liu B, Chen Y, St Clair DK. ROS and p53: a versatile partnership. Free Radic Biol Med. 2008;44(8):1529-35. 
Lo $\mathrm{H}$, Wang $\mathrm{Z}, \mathrm{Hu} \mathrm{Y}$ et al. Allelic variation in gene expression is common in the human genome. Genome Res. 2003;13:1855-1862.

Lowry OH, Rosebrough NJ, Farr AL, Randall RJ. Protein measurement with the Folin phenol reagent. J Biol Chem. 1951;193 :265-75.

Lubbe SJ, Pittman AM, Olver B et al. The 14q22.2 colorectal cancer variant rs4444235 shows cis-acting regulation of BMP4. Oncogene. 2012;31:3777-3784.

Maiuri MC, Zalckvar E, Kimchi A, Kroemer G. Self-eating and self-killing: crosstalk between autophagy and apoptosis. Nat Rev Mol Cell Biol. 2007;8(9):741-52.

Martin LP, Hamilton TC, Schilder RJ. Platinum resistance: the role of DNA repair pathways. Clin Cancer Res. 2008;14(5):1291-5.

Masutani C, Araki M, Yamada A, et al. Xeroderma pigmentosum variant (XP-V) correcting protein from HeLa cells has a thymine dimer bypass DNA polymerase activity. EMBO J. 1999;18:3491-3501.

Mathonnet G, Leger C, Desnoyers J, Drouin R, Therrien JP, Drobetsky EA. UV wavelength-dependent regulation of transcription-coupled nucleotide excision repair in p53-deficient human cells. Proc. Natl. Acad. Sci. 2003;100:7219-7224.

Matsumura Y, Ananthaswamy HN. Short-term and long-term cellular and molecular events following UV irradiation of skin: implications for molecular medicine. Expert Rev Mol Med. 2002;4:1-22.

Miao F, Bouziane M, Dammann R, Masutani C, Hanaoka F, Pfeifer G, O'Connor TR. 3Methyladenine-DNA glycosylase (MPG protein) interacts with human RAD23 proteins. J Biol Chem. 2000;275(37):28433-8.

Millikan RC, Hummer A, Begg C, et al. Polymorphisms in nucleotide excision repair genes and risk of multiple primary melanoma: the Genes Environment and Melanoma Study. Carcinogenesis. 2006; 27:610-8.

Minotti G, Menna P, Salvatorelli E, Cairo G, Gianni L. Anthracyclines: molecular advances and pharmacologic developments in antitumor activity and cardiotoxicity. Pharmacol Ver. 2004;56:185-229.

Mirmohammadsadegh A, Mota R, Gustrau A, Hassan M, Nambiar S, Marini A, Bojar $\mathrm{H}$, Tannapfel A, Hengge UR. ERK1/2 is highly phosphorylated in melanoma metastases and protects melanoma cells from cisplatin-mediated apoptosis. J Invest Dermatol. 2007;127(9):2207-15

Mitchell DL. Effects of cytosine methylation on pyrimidine dimer formation in DNA. Photochem Photobiol. 2000;71:162-165. 
Molognoni F, de Melo FH, da Silva CT, Jasiulionis MG.Ras and Rac1, frequently mutated in melanomas, are activated by superoxide anion, modulate Dnmt1 level and are causally related to melanocyte malignant transformation. PLoS One. 2013;8(12):e81937.

Morley M, Molony CM, Weber TM et al. Genetic analysis of genome-wide variation in human gene expression. Nature. 2004;430(7001):743-7.

Muallem MZ, Braicu I, Nassir M, Richter R, Sehouli J, Arsenic R. ERCC1 expression as a predictor of resistance to platinum-based chemotherapy in primary ovarian cancer. Anticancer Res. 2014;34(1):393-9.

Muthusamy V, Hobbs C, Nogueira C, Cordon-Cardo C, McKee PH, Chin L, Bosenberg MW. Amplification of CDK4 and MDM2 in malignant melanoma. Genes Chromosomes Cancer. 2006;45(5):447-54.

Naccarati A, Soucek P, Stetina R, et al. Genetic polymorphisms and possible gene-gene interactions in metabolic and DNA repair genes: effects on DNA damage. Mutat Res 2006; 593:22-31. Nature. 1994;372(6508):773-6

Nazarewicz RR, Dikalova A, Bikineyeva A, Ivanov S, Kirilyuk IA, Grigor'ev IA, Dikalov SI. Does scavenging of mitochondrial superoxide attenuate cancer prosurvival signaling pathways? Antioxid Redox Signal. 2013;19(4):344-9.

$\mathrm{Ng} \mathrm{JM}$, Vermeulen W, van der Horst GT, et al. A novel regulation mechanism of DNA repair by damage-induced and RAD23-dependent stabilization of xeroderma pigmentosum group C protein. Genes Dev. 2003; 17:1630-45.

Ng JM, Vrieling H, Sugasawa K, Ooms MP, Grootegoed JA, Vreeburg JT, Visser P, Beems RB, Gorgels TG, Hanaoka F, Hoeijmakers JH, van der Horst GT. Developmental defects and male sterility in mice lacking the ubiquitin-like DNA repair gene mHR23B. Mol Cell Biol. 2002;22:1233-45.

Nishi R, Okuda Y, Watanabe E, Mori T, Iwai S, Masutani C, Sugasawa K, Hanaoka F. Centrin 2 stimulates nucleotide excision repair by interacting with xeroderma pigmentosum group C protein. Mol Cell Biol. 2005;25(13):5664-74.

Noonan FP, Dudek J, Merlino G, De Fabo EC. Animal models of melanoma: an HGF/SF transgenic mouse model may facilitate experimental access to UV initiating events. Pigment Cell Res. 2003;16: 16-25.

Noonan FP, Otsuka T, Bang S, Anver MR, Merlino G. Accelerated ultravioleta radiation-induced carcinogenesis in hepatocyte growth factor/scatter fator transgenic mice. Cancer Res. 2000;60: 3738-3743.

Noonan FP, Recio JA, Takayama $\mathrm{H}$, et al. Neonatal sunburn and melanomain mice. Nature. 2001;413: 271-272. 
Nouspikel T. DNA repair in mammalian cells: Nucleotide excision repair: variations on versatility. Cell Mol Life Sci. 2009;66(6):994-1009.

Oba-Shinjo SM, Correa M, Ricca TI, Molognoni F, Pinhal MA, Neves IA, Marie SK, Sampaio LO, Nader HB, Chammas R, Jasiulionis MG. Melanocyte transformation associated with substrate adhesion impediment. Neoplasia. 2006;8(3):231-41.

Okuda Y, Nishi R, Ng JM, Vermeulen W, van der Horst GT, Mori T, Hoeijmakers JH, Hanaoka F, Sugasawa K. Relative levels of the two mammalian Rad23 homologs determine composition and stability of the xeroderma pigmentosum group $\mathrm{C}$ protein complex. DNA Repair (Amst). 2004;3(10):1285-95.

Oliveira C, Rinck-Junior JA, Lourenço GJ, Moraes AM, Lima CS. Assessment of the XPC (A2920C), XPF (T30028C), TP53 (Arg72Pro) and GSTP1 (Ile105Val) polymorphisms in the risk of cutaneous melanoma. J Cancer Res Clin Oncol. 2013;139(7):1199-206.

Opletalova K, Bourillon A, Yang W, Pouvelle C, Armier J, Despras E, Ludovic M, Mateus C, Robert C, Kannouche P, Soufir N, Sarasin A. Correlation of phenotype/genotype in a cohort of 23 xeroderma pigmentosum-variant patients reveals 12 new disease-causing POLH mutations. Hum Mutat. 2014;35(1):117-28.

Ortolan TG, Tongaonkar P, Lambertson D, Chen L, Schauber C, Madura K. The DNA repair protein $\operatorname{rad} 23$ is a negative regulator of multi-ubiquitin chain assembly. Nat Cell Biol. 2000;2:601-8.

Pavanello S, Pulliero A, Siwinska E, Mielzynska D, Clonfero E. Reduced nucleotide excision repair and GSTM1-null genotypes influence anti-B[a]PDE-DNA adduct levels in mononuclear white blood cells of highly PAH-exposed coke oven workers. Carcinogenesis. 2005; 26:169-75.

Peirce SK, Findley HW. The MDM2 antagonist nutlin-3 sensitizes p53-null neuroblastoma cells to doxorubicin via E2F1 and TAp73. Int J Oncol. 2009; 34:1395402.

Peng B, Hodge DR, Thomas SB, Cherry JM, Munroe DJ, Pompeia C, Xiao W, Farrar WL. Epigenetic silencing of the human nucleotide excision repair gene, hHR23B, in interleukin-6-responsive multiple myeloma KAS-6/1 cells. $J$ Biol Chem. 2005;280(6):4182-7.

Perlis C, Herlyn M. Recent advances in melanoma biology. Oncologist. 2004; 9:182-7.

Pfaffl MW. A new mathematical model for relative quantification in real-time RT-PCR. Nucleic Acids Res. 2001;29(9):e45.

Pfeifer GP, You YH, Besaratinia A. Mutations induced by ultraviolet light. Mutat Res. 2005;571:19-31. 
Pillay N, Plagnol V, Tarpey PS, Lobo SB, Presneau N, Szuhai K, Halai D, Berisha F, Cannon SR, Mead S, Kasperaviciute D, Palmen J, Talmud PJ, Kindblom LG, Amary MF, Tirabosco R, Flanagan AM. A common single-nucleotide variant in $\mathrm{T}$ is strongly associated with chordoma. Nat Genet. 2012;44(11):1185-7.

Pleasance ED, Cheetham RK, Stephens PJ, McBride DJ, Humphray SJ, Greenman CD, Varela I, Lin ML, Ordóñez GR, Bignell GR, Ye K, Alipaz J, Bauer MJ, Beare D, Butler A, Carter RJ, Chen L, Cox AJ, Edkins S, Kokko-Gonzales PI, Gormley NA, Grocock RJ, Haudenschild CD, Hims MM, James T, Jia M, Kingsbury Z, Leroy C, Marshall J, Menzies A, Mudie LJ, Ning Z, Royce T, Schulz-Trieglaff OB, Spiridou A, Stebbings LA, Szajkowski L, Teague J, Williamson D, Chin L, Ross MT, Campbell PJ, Bentley DR, Futreal PA, Stratton MR. A comprehensive catalogue of somatic mutations from a human cancer genome. Nature. 2010;463(7278):191-6.

Polsky D, Melzer K, Hazan C, Panageas KS, Busam K, Drobnjak M, Kamino H, Spira JG, Kopf AW, Houghton A, Cordon-Cardo C, Osman I. HDM2 protein overexpression and prognosis in primary malignant melanoma. J Natl Cancer Inst. 2002;94(23):1803-6.

Povey JE, Darakhshan F, Robertson K, et al. DNA repair gene polymorphisms and genetic predisposition to cutaneous melanoma. Carcinogenesis. 2007; 28:1087-93.

Preston TJ, Muller WJ, Singh G. Scavenging of extracellular $\mathrm{H} 2 \mathrm{O} 2$ by catalase inhibits the proliferation of HER-2/Neu-transformed rat-1 fibroblasts through the induction of a stress response. J Biol Chem. 2001;276(12):9558-64.

Qiao Y, Spitz MR, Guo Z, Hadeyati M, Grossman L, Kraemer KH, Wei Q. Rapid assessment of repair of ultraviolet DNA damage with a modified host-cell reactivation assay using a luciferase reporter gene and correlation with polymorphisms of DNA repair genes in normal human lymphocytes. Mutat Res. 2002;509(1-2):165-74.

R\&D systems. DNA repair pathways. Disponível em: <URL: http://www.rndsystems.com/mini_review_detail_objectname_MR03_DNADamageRes ponse.aspx> 2003. [2007 jul 02].

Renaud E, Miccoli L, Zacal N, Biard DS, Craescu CT, Rainbow AJ, Angulo JF. Differential contribution of XPC, RAD23A, RAD23B and CENTRIN 2 to the UVresponse in human cells. DNA Repair (Amst). 2011;10(8):835-47.

Roche Y, Zhang D, Segers-Nolten GM, Vermeulen W, Wyman C, Sugasawa K, Hoeijmakers J, Otto C. Fluorescence correlation spectroscopy of the binding of nucleotide excision repair protein XPC-hHr23B with DNA substrates. J Fluoresc. 2008;18(5):987-95.

Rodriguez-Rocha H, Garcia-Garcia A, Panayiotidis MI, Franco R. DNA damage and autophagy. Mutat Res. 2011;711(1-2):158-66.

Sadee W, Wang D, Papp AC, et al. Pharmacogenomics of the RNA world: structural RNA polymorphisms in drug therapy. Clin Pharmacol Ther. 2011;89:355-65. 
Saffi J, Agnoletto MH, Guecheva TN, Batista LF, Carvalho H, Henriques JA, Stary A, Menck CF, Sarasin A. Effect of the anti-neoplastic drug doxorubicin on XPD-mutated DNA repair-deficient human cells. DNA Repair (Amst). 2010;9(1):40-7.

Sander CS, Chang H, Hamm F, Elsner P, Thiele JJ. Role of oxidative stress and the antioxidant network in cutaneous carcinogenesis. Int J Dermatol. 2004;43(5):326-35.

Sanyal S, Festa F, Sakano S, et al. Polymorphisms in DNA repair and metabolic genes in bladder cancer. Carcinogenesis. 2004; 25:729-34.

Sarasin A, Stary A. New insights for understanding the transcription-coupled repair pathway. DNA Repair (Amst). 2007; 6:265-9.

Senff-Ribeiro A, Echevarria A, Silva EF, Franco CR, Veiga SS, Oliveira MB. Cytotoxic effect of a new 1,3,4-thiadiazolium mesoionic compound (MI-D) on cell lines of human melanoma. Br J Cancer. 2004 Jul 19;91(2):297-304.

Shangary S, Wang S. Small-molecule inhibitors of the MDM2-p53 protein-protein interaction to reactivate p53 function: a novel approach for cancer therapy. Annu Rev Pharmacol Toxicol. 2009;49:223-41.

Shen H, Maki CG. Pharmacologic activation of p53 by small-molecule MDM2 antagonists. Curr Pharm Des. 2011;17(6):560-8.

Shen J, Medico L, Zhao HW: Allelic imbalance in BRCA1 and BRCA2 gene expression and familial ovarian cancer. Cancer Epidemiol Biomarkers Prev. 2010;20,50-56.

Shimizu Y, Iwai S, Hanaoka F, Sugasawa K. Xeroderma pigmentosum group C protein interacts physically and functionally with thymine DNA glycosylase. EMBO J. 2003;22(1):164-73.

Slominski A, Tobin DJ, Shibahara S, Wortsman J. Melanin pigmentation in mammalian skin and its hormonal regulation. Physiol Rev. 2004; 84:1155-228.

Smith ML, Ford JM, Hollander MC, Bortnick RA, Amundson, A, Seo YR, Deng CX, Hanawalt PC, Fornace AJ. p53-Mediated DNA repair responses to UV radiation: Studies of mouse cells lacking p53, p21 and/orgadd45 genes. Mol Cel. Biol. 2000, 20, 3705-3714.

Song L, Ritchie AM, McNeil EM, Li W, Melton DW. Identification of DNA repair gene Ercc1 as a novel target in melanoma. Pigment Cell Melanoma Res. 2011, 24, 966971.

Sousa JF, Espreafico EM. Suppression subtractive hybridization profiles of radial growth phase and metastatic melanoma cell lines reveal novel potential targets. BMC Cancer. 2008;8:19. 
Spatz A, Giglia-Mari G, Benhamou S, Sarasin A. Association between DNA repairdeficiency and high level of p53 mutations in melanoma of Xeroderma pigmentosum. Cancer Res. 2001;61(6):2480-6.

Stevnsner T, Muftuoglu M, Aamann MD, Bohr VA. The role of Cockayne Syndrome group B (CSB) protein in base excision repair and aging. Mech Ageing Dev. 2008;129(7-8):441-8.

Stigger E, Drissi R, Lee SH. Functional analysis of human replication protein A in nucleotide excision repair. J Biol Chem. 1998; 273:9337-43.

Stoyanova T, Roy N, Kopanja D, Raychaudhuri P, Bagchi S. DDB2 (damaged-DNA binding protein 2) in nucleotide excision repair and DNA damage response. Cell Cycle. 2009;8(24):4067-71.

Strauss BE, Bajgelman MC, Costanzi-Strauss E. A novel gene transfer strategy that combines promoter and transgene activities for improved tumor cell inhibition. Cancer Gene Ther. 2005;12(12):935-46.

Strauss BE, Costanzi-Strauss E. pCLPG: a p53-driven retroviral system. Virology. 2004;321(2):165-72.

Stuhmer T, Chatterjee M, Hildebrandt M, Herrmann P, Gollasch H, Gerecke C, Theurich S, Cigliano L, Manz RA, Daniel PT, Bommert K, Vassilev LT, Bargou RC. Blood. 2005;106(10):3609-17.

Sturm RA, Satyamoorthy K, Meier F, Gardiner BB, Smit DJ, Vaidya B, Herlyn M. Osteonectin/SPARC induction by ectopic beta(3) integrin in human radial growth phase primary melanoma cells. Cancer Res. 2002;62(1):226-32.

Sugasawa K, Okamoto T, Shimizu Y, Masutani C, Iwai S, Hanaoka F. A multistep damage recognition mechanism for global genomic nucleotide excision repair. Genes Dev. 2001; 15:507-21.

Sugasawa K, Shimizu Y, Iwai S, Hanaoka F. A molecular mechanism for DNA damage recognition by the xeroderma pigmentosum group $\mathrm{C}$ protein complex. DNA Repair. (Amst) 2002; 1:95-107.

Sugasawa K. UV-induced ubiquitylation of XPC complex, the UV-DDB-ubiquitin ligase complex, and DNA repair. Mol Histol. 2006;37:189-202.

Sui X, Jin L, Huang X, Geng S, He C, Hu X. p53 signaling and autophagy in cancer: a revolutionary strategy could be developed for cancer treatment. Autophagy. 2011;7(6):565-71.

Sui X, Kong N, Ye L, Han W, Zhou J, Zhang Q, He C, Pan H. p38 and JNK MAPK pathways control the balance of apoptosis and autophagy in response to chemotherapeutic agents. Cancer Lett. 2014;344(2):174-9. 
Tan T \& Chu G. p53 binds and activates the xeroderma pigmentosum DDB2 gene in humans, but not mice. Mol Cell Biol. 2002, 22, 3247-3254.

Terzian T, Torchia EC, Dai D, Robinson SE, Murao K, Stiegmann RA, et al. p53 prevents progression of nevi to melanoma predominantly through cell cycle regulation. Pigment Cell Melanoma Res. 2010;23(6):781-94.

Tommasi S, Denissenko MF, Pfeifer GP. Sunlight induces pyrimidine dimers preferentially at 5-methylcytosine bases. Cancer Res. 1997;57: 4727-4730.

Torres SM, Luo L, Lilyquist J, Stidley CA, Flores K, White KA, Erdei E, Gonzales M, Paine S, Vogel RI, Lazovich D, Berwick M. DNA repair variants, indoor tanning, and risk of melanoma. Pigment Cell Melanoma Res. 2013;26(5):677-84.

Traversari C, van der Bruggen P, Van den Eynde B, Hainaut P, Lemoine C, Ohta N, Old L, Boon T. Transfection and expression of a gene coding for a human melanoma antigen recognized by autologous cytolytic $\mathrm{T}$ lymphocytes. Immunogenetics. 1992;35(3):145-52.

Vassilev LT, Vu BT, Graves B, Carvajal D, Podlaski F, Filipovic Z, Kong N, Kammlott U, Lukacs C, Klein C, Fotouhi N, Liu EA. In vivo activation of the p53 pathway by small-molecule antagonists of MDM2. Science. 2004;303(5659):844-8.

Verhaegen M, Checinska A, Riblett MB, Wang S, Soengas MS. E2F1-dependent oncogenic addiction of melanoma cells to MDM2. Oncogene. 2012;31(7):828-41.

Verma R, Oania R, Graumann J, Deshaies RJ. Multiubiquitin chain receptors define a layer of substrate selectivity in the ubiquitin-proteasome system. Cell. 2004;118:99-110.

Vodicka P, Kumar R, Stetina R, et al. Genetic polymorphisms in DNA repair genes and possible links with DNA repair rates, chromosomal aberrations and single-strand breaks in DNA. Carcinogenesis. 2004; 25:757-63.

Wang HT, Choi B, Tang, M. Melanocytes are deficient in repair of oxidative DNA damage and UV-induced photoproducts. Proc. Natl. Acad. Sci. USA 2010, 107, 1218012185 .

Wang Y, Digiovanna JJ, Stern JB, Hornyak TJ, Raffeld M, Khan SG, Oh KS, Hollander MC, Dennis PA, Kraemer KH. Evidence of ultraviolet type mutations in xeroderma pigmentosum melanomas. Proc Natl Acad Sci U S A. 2009;106(15):6279-84.

Weatherhead SC, Haniffa M, Lawrence CM. Melanomas arising from naevi and de novo melanomas - does origin matter? Br J Dermatol. 2007;156: 72-76.

Weeda G, van Ham RC, Vermeulen W, Bootsma D, van der Eb AJ, Hoeijmakers JH. A presumed DNA helicase encoded by ERCC-3 is involved in the human repair disorders xeroderma pigmentosum and Cockayne's syndrome. Cell. 1990; 62:777-91. 
Wenk J, Brenneisen P, Meewes C, Wlaschek M, Peters T, Blaudschun R, Ma W, Kuhr L, Schneider L, Scharffetter-Kochanek K. UV-induced oxidative stress and photoaging. Curr Probl Dermatol. 2001;29:83-94.

Wu YH, Wu TC, Liao JW, Yeh KT, Chen CY, Lee H. p53 dysfunction by xeroderma pigmentosum group $\mathrm{C}$ defects enhance lung adenocarcinoma metastasis via increased MMP1 expression. Cancer Res. 2010;70(24):10422-32.

Ye W, Kumar R, Bacova G, Lagergren J, Hemminki K, Nyren O. The XPD 751Gln allele is associated with an increased risk for esophageal adenocarcinoma: a populationbased case-control study in Sweden. Carcinogenesis. 2006; 27:1835-41.

Yu H, McDaid R, Lee J, Possik P, Li L, Kumar SM, et al. The role of BRAF mutation and p53 inactivation during transformation of a subpopulation of primary human melanocytes. Am J Pathol. 2009;174(6):2367-77.

Yuan Z, Cao K, Lin C, Li L, Liu HY, Zhao XY, Liu L, Deng HX, Li J, Nie CL, Wei YQ. The p53 upregulated modulator of apoptosis (PUMA) chemosensitizes intrinsically resistant ovarian cancer cells to cisplatin by lowering the threshold set by $\mathrm{Bcl}-\mathrm{x}(\mathrm{L})$ and Mcl-1. Mol Med. 2011;17(11-12):1262-74.

Zhang J, Walter JC. Mechanism and regulation of incisions during DNA interstrand cross-link repair. DNA Repair (Amst). 2014;19:135-42.

Zhang L, Zhang Z, Yan W. Single nucleotide polymorphisms for DNA repair genes in breast cancer patients. Clin Chim Acta. 2005; 359:150-5.

Zhu B, Chen Z, Cheng X, Lin Z, Guo J, Jia Z, Zou L, Wang Z, Hu Y, Wang D, Wu Y. Identification of HLA-A*0201-restricted cytotoxic T lymphocyte epitope from TRAG-3 antigen. Clin Cancer Res. 2003;9(5):1850-7.

Ziegler A, Jonason AS, Leffell DJ, Simon JA, Sharma HW, Kimmelman J, Remington L, Jacks T, Brash DE. Sunburn and p53 in the onset of skin cancer. Nature. 1994;372(6508):773-6.

Zong WX, Moll U. p53 in autophagy control. Cell Cycle. 2008;7:2947. 